DANIEL GUSTAVO FALCÃO PIMENTEL DOS REIS

\title{
FINANCIAMENTO DA POLÍTICA NO BRASIL
}

\author{
DISSERTAÇÃO DE MESTRADO \\ ORIENTADOR: PROFESSOR TITULAR \\ LUÍS VIRGÍLIO AFONSO DA SILVA
}

UNIVERSIDADE DE SÃO PAULO

FACULDADE DE DIREITO

SÃO PAULO

2010 


\title{
DANIEL GUSTAVO FALCÃO PIMENTEL DOS REIS
}

\section{FINANCIAMENTO DA POLÍTICA NO BRASIL}

Dissertação de Mestrado apresentada no Programa de Pós-Graduação Stricto Sensu da Faculdade de Direito da Universidade de São Paulo, como requisito para a obtenção do título de Mestre em Direito do Estado, sob a orientação do Professor Titular Luís Virgílio Afonso da Silva.

\section{UNIVERSIDADE DE SÃO PAULO}

FACULDADE DE DIREITO

\author{
SÃO PAULO
}


Aos meus pais, Regina e Lúcio, por todo apoio, carinho, compreensão e paciência dados desde sempre.

À minha irmã, Sarah, por toda ajuda e pela maravilhosa e afetuosa convivência. 


\section{AGRADECIMENTOS}

Meu primeiro agradecimento é dirigido ao meu orientador Luís Virgílio Afonso da Silva, por todas as indicações dadas para a realização desta pesquisa, por compreender as dificuldades trazidas pela combinação pós-graduação e trabalho, além de ter me dado a primeira oportunidade de conhecer uma nova paixão: a docência.

Aos membros da banca de qualificação, Professores Monica Herman Salem Caggiano e Matthew Macleod Taylor, por todas as críticas e sugestões dadas para a melhor realização da pesquisa e deste trabalho.

Da mesma forma, não posso deixar de mencionar os Professores Flávio Luiz Yarshell e Luiz Carlos dos Santos Gonçalves, ambos com atuação destacada no âmbito eleitoral paulista, pela gentileza de atenderem meu pedido para que eu pudesse entender melhor a função da Justiça Eleitoral e do Ministério Público Eleitoral no contexto estudado neste trabalho.

A Wladimir Azevedo Caetano e Filippe Lizardo, por me esclarecerem os meandros e as nuances das prestações de contas partidárias e eleitorais no âmbito nacional e paulista, respectivamente.

Aos funcionários da Biblioteca Professor Alysson Darowish Mitraud, do Tribunal Superior Eleitoral; e da Biblioteca Acadêmico Luiz Viana Filho, do Senado Federal, pela atenciosa ajuda dada em minha pesquisa feita em Brasília em maio de 2009.

Aos funcionários da Biblioteca da Faculdade de Direito da Universidade de São Paulo, em especial a Aurélio Santos, Eduardo Aguiar, Maria da Paixão "Nilda" de Queiroz, Luciana Napoleone e Maria Lucia Beffa, por toda ajuda e carinho prestados em todas às vezes que pesquisei e trabalhei nela. 
Aos funcionários das Arcadas Mario Sergio de Oliveira e Silva, Vera Lúcia de Souza e Sylvia Regina Ferreira, que da mesma forma sempre me ajudaram com presteza nos assuntos administrativos da Pós-Graduação do Largo São Francisco.

Às minhas chefas Regina Aparecida Vieira dos Santos e Maria Vitória de Souza Castro e Silva, pela amizade e por compreenderem as dificuldades que existem ao se conciliar o trabalho e a pós-graduação.

Aos meus amigos Eduardo Pontieri, James Siqueira, Érico Pilatti, José Flávio Bianchi, Gustavo Mathias Alves Pinto, Marcelo Passamani Machado, Alexandre Sanson, Cristina Godoy, Pythagoras Lopes de Carvalho Neto, Roberto Dutra, Cláudio Castello, Ana Carolina Cavalcanti de Albuquerque, Daniele Maciel, Hector Ferraz, André Bueno da Silveira, Giacomo Cenci e Felippe Monteiro, pela extraordinária convivência e pelo apoio tanto nos momentos bons como também nos momentos ruins.

Ao meu "bebezinho", minha caçula Sarah, pelo carinho, amor e alegria dados desde 1988.

Finalmente, destino o maior agradecimento aos meus pais, Regina e Lúcio, por todo amor, carinho, ajuda, paciência e compreensão dados desde o primeiro momento. Simplesmente devo tudo o que tenho e tudo o que sou a eles. 


\section{RESUMO}

Reis, Daniel Gustavo Falcão Pimentel dos. Financiamento da política no Brasil. 2010. Dissertação (Mestrado) Faculdade de Direito da Universidade de São Paulo, São Paulo, 2010.

O objetivo da presente dissertação é analisar o sistema normativo que rege o financiamento da atividade política no Brasil. Para tanto, o trabalho inicia com a abordagem das principais fragilidades apresentadas pelo sistema político-eleitoral brasileiro como um todo para que se possa entender melhor o contexto em que está envolvido o sistema normativo do financiamento da política no Brasil. Após, são analisadas as principais propostas de reforma legislativas do cenário político-eleitoral brasileiro. Nesse ínterim, ganha destaque as alterações propostas no sistema de financiamento de caráter misto atualmente vigente no Brasil. Posteriormente, há uma análise de todos os dispositivos legais referentes ao tema, a fim de se entender os problemas específicos do financiamento dos partidos políticos e das campanhas eleitorais brasileiras. Segue-se uma pesquisa empírica em que são estudadas as prestações de contas eleitorais apresentadas nas eleições presidenciais de 2002 e 2006, com o intuito de se observar se as premissas existentes na doutrina referente ao tema realmente se aplicam na prática.

Palavras-chave: Financiamento da política. Campanhas eleitorais. Partidos políticos. Reforma Política. 


\begin{abstract}
Reis, Daniel Gustavo Falcão Pimentel dos. Financing politics in Brazil. 2010. Dissertation (Master) Faculty of Law of the University of São Paulo, São Paulo, 2010

The objective of this work is to analyze the normative system that conducts the financing of the activity politics in Brazil. For in such a way, the work initiates with the boarding of the main fragilities presented for Brazilian politician-electoral system as a whole so that if it can understand the context better where the normative system of the financing of the politics in Brazil is involved. After, the main legislative proposals of reform of the Brazilian politician-electoral scene are analyzed. In this meantime, it gains prominence the alterations proposals in the currently normative financing system in Brazil. Later, it has an analysis of all the referring legal devices to the subject, in order to understand the specific problems of the financing of the political parties and the Brazilian electoral campaigns. An empirical research is followed where the presented electoral renderings of accounts in the presidential elections of 2002 and 2006 are studied, with the intention of observing if the existing premises in the referring doctrine to the subject really they are applied in the practical one.
\end{abstract}

Key words: Financing politics. Electoral campaigns. Political parties. Political reform legislation. 


\section{SIGLÁRIO}

ADI - Ação Direta de Inconstitucionalidade

AIJE - Ação de Investigação Judicial Eleitoral

AIME - Ação de Impugnação de Mandato Eletivo

Bacen - Banco Central do Brasil

CE - Código Eleitoral (Lei n. 4.737/65)

CCJC - Comissão de Constituição, Justiça e Cidadania da Câmara dos Deputados

CRFB - Constituição da República Federativa do Brasil, de 05 de outubro de 1988

DEM - Democratas, antigo PFL.

DJ - Diário da Justiça

DJE - Diário da Justiça Eletrônico

$\mathrm{HC}$ - Habeas Corpus

LE - Lei das Eleições (Lei n. 9.504/97)

LPP - Lei dos Partidos Políticos (Lei n. 9.096/95)

LI - Lei das Inelegibilidades (Lei Complementar n. 64/90)

PAN - Partido dos Aposentados da Nação (incorporado ao PTB em 2006)

PCB - Partido Comunista Brasileiro (1996-)

PC do B - Partido Comunista do Brasil

PCO - Partido da Causa Operária

PDS - Partido Democrático Social, atual PP.

PDT - Partido Democrático Trabalhista

PEC - Proposta de Emenda à Constituição

PFL - Partido da Frente Liberal, atual DEM

PGT - Partido Geral dos Trabalhadores (incorporado ao PL, hoje PR, em 2003)

PHS - Partido Humanista da Solidariedade

PL - Projeto de Lei

PL - Partido Liberal, atual PR.

PLP - Projeto de Lei Complementar

PLS - Projeto de Lei do Senado

PMDB - Partido do Movimento Democrático Brasileiro

PMN - Partido da Mobilização Nacional

PP - Partido Progressista, antigo PDS, PPR e PPB. 
PPB - Partido Progressista Brasileiro, atual PP.

PPS - Partido Popular Socialista, antigo PCB (1922-1991)

PR - Partido da República, antigo PL.

PRN - Partido da Reconstrução Nacional, atual PTC.

PRONA - Partido de Reedificação da Ordem Nacional

PRP - Partido Republicano Progressista

PSB - Partido Socialista Brasileiro

PSC - Partido Social Cristão

PSDB - Partido da Social Democracia Brasileira

PSDC - Partido Social Democrata Cristão

PSOL - Partido Socialismo e Liberdade

PST - Partido Social Trabalhista (incorporado ao PL, hoje PR, em 2003)

PSTU - Partido Socialista dos Trabalhadores Unificado

PT - Partido dos Trabalhadores

PTC - Partido Trabalhista Cristão, antigo PRN.

PTB - Partido Trabalhista Brasileiro.

PV - Partido Verde

REspe - Recurso Especial Eleitoral

RFB - Secretaria da Receita Federal do Brasil

RICD - Regimento Interno da Câmara dos Deputados (Resolução n. 17/1989).

SAL-MJ - Secretaria de Assuntos Legislativos do Ministério da Justiça

SPCE - Sistema de Prestação de Contas Eleitorais

SRF - Secretaria da Receita Federal, atual RFB - Secretaria da Receita Federal do

Brasil

STF - Supremo Tribunal Federal

TRE-SP - Tribunal Regional Eleitoral de São Paulo

TSE - Tribunal Superior Eleitoral 


\section{LISTA DE TABELAS}

Tabela 1- Resultado $1^{\circ}$ Turno Eleição Presidencial (6.10.2002)

Tabela 2 - Resultado $2^{\circ}$ Turno Eleição Presidencial (27.10.2002

Tabela 3 - Origem da Arrecadação (Ciro Gomes e Anthony Garotinho)

Tabela 4 - Origem da Arrecadação (José Serra e Luiz Inácio Lula da Silva)

Tabela 5 - Meio de Doação (Ciro Gomes e Anthony Garotinho)

Tabela 6 - Meio de doação (José Serra e Luiz Inácio Lula da Silva)

Tabela 7 - Período de Arrecadação (Ciro Gomes e Anthony Garotinho)

Tabela 8 - Pesquisas de Intenção de Voto $1^{\circ}$ Turno (Datafolha)

Tabela 9 - Período de Arrecadação (José Serra e Luiz Inácio Lula da Silva)

Tabela 10 - Pesquisas de Intenção de Voto $2^{\circ}$ Turno (Datafolha)

Tabela 11 - Período de Gastos Eleitorais (Ciro Gomes e Anthony Garotinho)

Tabela 12 - Período de Gastos Eleitorais (José Serra e Luiz Inácio Lula da Silva)

Tabela 13 - Saldo Financeiro das Campanhas

Tabela 14 - Tipos de Gastos Eleitorais (Ciro Gomes e Anthony Garotinho)

Tabela 15 - Tipos de Gastos Eleitorais (José Serra e Luiz Inácio Lula da Silva)

Tabela 16 - Resultado $1^{\circ}$ Turno Eleição Presidencial (1.10.2006)

Tabela 17 - Resultado $2^{\circ}$ Turno Eleição Presidencial (29.10.2006)

Tabela 18 - Origem da Arrecadação (Heloísa Helena e Cristovam Buarque)

Tabela 19 - Origem da Arrecadação (Luiz Inácio Lula da Silva e Geraldo Alckmin)

Tabela 20 - Período de Arrecadação (Heloísa Helena e Cristovam Buarque)

Tabela 21 - Período de Arrecadação (Luiz Inácio Lula da Silva e Geraldo Alckmin)

Tabela 22 - Pesquisas de Intenção de Voto $1^{\circ}$ Turno (Datafolha)

Tabela 23 - Pesquisas de Intenção de Voto $2^{\circ}$ Turno (Datafolha)

Tabela 24 - Período de Gastos Eleitorais (Luiz Inácio Lula da Silva e Geraldo Alckmin)

Tabela 25 - Período de Gastos Eleitorais (Heloísa Helena e Cristovam Buarque)

Tabela 26 - Tipos de Gastos Eleitorais (Heloísa Helena e Cristovam Buarque)

Tabela 27 - Tipos de Gastos Eleitorais (Luiz Inácio Lula da Silva e Geraldo Alckmin)

Tabela 28 - Saldo Financeiro das Campanhas

Tabela 29 - Tipos de Gastos Eleitorais (Luiz Inácio Lula da Silva 2002 e 2006)

Tabela 30 - Tipos de Gastos Eleitorais (José Serra - 2002 e Geraldo Alckmin - 2006) 


\section{SUMÁRIO}

Capítulo 1. Introdução 13

1.1. Tema a ser desenvolvido e sua importância 13

1.2. Metodologia 22

1.3. Plano do trabalho 23

Capítulo 2. Sistema político-eleitoral brasileiro: suas fragilidades e os possíveis remédios 26

2.1. Fragilidades do sistema político-eleitoral brasileiro 26

2.1.1. Sistema proporcional em lista aberta 30

2.1.1.1. Coligações partidárias nas eleições proporcionais 32

2.1.1.2. Candidaturas individuais $\quad 34$

2.1.2. Sistema partidário brasileiro 36

2.1.2.1. Infidelidade e indisciplina partidárias 38

2.1.2.2. Proliferação de partidos e a cláusula de desempenho $\quad 47$

2.1.3. Campanhas eleitorais: propaganda eleitoral no rádio e na televisão e o marketing político-eleitoral 55

2.1.4. Financiamento da política 65

2.2. Possíveis remédios ao quadro político-eleitoral brasileiro: as principais propostas de Reforma Política 76

2.2.1. Proposta da Comissão Especial de Reforma Política da Câmara dos Deputados (Projeto de Lei n. 2.679/2003) 77

2.2.2. Proposta da Comissão de Notáveis do Tribunal Superior $\begin{array}{ll}\text { Eleitoral } & 90\end{array}$

2.2.3. Proposta de Reforma Política do Governo Federal (Secretaria de Assuntos Legislativos do Ministério da Justiça) 100 2.2.4. Financiamento da Política de caráter Público x Financiamento da Política de caráter Privado: vantagens e desvantagens 108

Capítulo 3. Sistema normativo do financiamento da política no Brasil 122

3.1. Lei das Eleições (Lei n. 9.504/97) 123

3.1.1. Arrecadação, administração e aplicação de recursos nas campanhas eleitorais 
3.1.2. Doações: forma, limites, vedações e penas 133

3.1.3. Gastos eleitorais 145

3.1.4. Prestações de contas eleitorais $\quad 150$

3.2. Lei dos Partidos Políticos (Lei n. 9.096/95) 168

3.2.1. Finanças e contabilidade partidárias $\quad 168$

3.2.2. Fundo Partidário 173

3.2.3. Horário Partidário e Eleitoral Gratuito 181

3.3. Código Eleitoral (Lei n. 4.737/65) 185

3.4. Lei das Inelegibilidades (Lei Complementar n. 64/90) 189

Capítulo 4. Análise das prestações de contas das campanhas presidenciais de 2002 e $2006 \quad 195$

4.1. Parâmetros para a análise das prestações de contas presidenciais 195

4.2. Eleições Presidenciais de $2002 \quad 201$

4.3. Eleições Presidenciais de 2006

4.4. Comparativo entre as eleições presidenciais de 2002 e 2006 e a Lei n. 11.300/2006 225

Capítulo 5. Considerações Finais 228

$\begin{array}{ll}\text { Bibliografia } & 230\end{array}$ 


\section{INTRODUÇÃO}

\subsection{Tema a ser desenvolvido e sua importância}

As leis eleitorais brasileiras sempre foram caracterizadas por sua existência breve. A cada novo período eleitoral, o Congresso Nacional aprovava uma nova lei para reger as eleições seguintes, fazendo com que a cada dois anos tivéssemos uma nova regulamentação do processo eleitoral ${ }^{1}$.

Porém, na década de 90 do século passado, com edição da Lei dos Partidos Políticos (Lei n. 9.096/95) e da Lei das Eleições (Lei n. 9.504/97), ambas elaboradas pelo Congresso e tituladas, na época, como as leis definitivas sobre o processo eleitoral brasileiro, houve a impressão de que a conturbada fase de mudanças constantes na legislação eleitoral estivesse encerrada.

No entanto, o tema da reforma política está na pauta da política brasileira desde o advento da Constituição de 1988. Políticos, acadêmicos e a opinião pública têm consciência das falhas e fragilidades do sistema político-eleitoral nacional.

As análises concernentes ao cenário político brasileiro detectam uma série de institutos previstos na legislação político-eleitoral que carecem de mudanças visando ao aperfeiçoamento da democracia brasileira. Nestes estudos, destacam-se os seguintes temas ${ }^{2}$ : (i) a infidelidade partidária; (ii) a ausência de uma cláusula de desempenho (ou de barreira) para os partidos políticos; (iii) o sistema eleitoral proporcional; (iv) as campanhas eleitorais e seu funcionamento; e (v) o financiamento da atividade política no país, por meio do financiamento dos partidos políticos e/ou das campanhas eleitorais.

Assim sendo, o tema ser tratado neste trabalho é o financiamento da política no Brasil. A análise consistirá no estudo dos aspectos relacionados ao tema no panorama político brasileiro, no exame dos dispositivos normativos aplicáveis, no debate sobre os sistemas de financiamento vigente hoje em outros países e por fim na pesquisa empírica

\footnotetext{
${ }^{1}$ Cf. Tarcisio Viera. "Experiencias nacionales representativas: Brasil”, in Daniel Zovatto et.all (coord.). Dinero y contienda político-electoral: reto de la democracia. México: Fondo de Cultura Económica ${ }^{2}$ Ressalte-se que esses pontos são também merecedores da atenção dos legisladores proponentes de projetos de reforma das normas eleitorais.
} 
que aborda as prestações de contas apresentadas à Justiça Eleitoral, para que se possa entender melhor como elas são feitas e quais são as reais receitas e despesas das campanhas eleitorais no Brasil.

O sistema brasileiro de financiamento de campanhas eleitorais e dos partidos políticos vigente hoje no país pode ser definido como de caráter misto, com forte predominância privada. Para pagar as despesas de sua campanha, o candidato pode tanto usar dinheiro público como procurar mais recursos na iniciativa privada ou entre seu eleitorado. No sistema brasileiro em vigor, os recursos privados são claramente predominantes nas campanhas de qualquer espécie, aparecendo com grande destaque nas campanhas de maior sucesso eleitoral. Segundo Jairo Nicolau, só têm chances de arrecadar recursos nos meios empresariais candidatos com o mínimo de chance eleitoral, podendo assim realizar "uma campanha minimamente competitiva".

A predominância das doações com origem no setor privado (em especial de pessoas jurídicas) pode causar distorções na legitimidade do processo eleitoral, impedindo que a concorrência entre os partidos políticos e os candidatos seja justa e equânime. Os candidatos e os partidos que conseguem arrecadar mais dinheiro para suas campanhas têm muito mais chance de serem eleitos que a maioria dos postulantes, que contam com poucos recursos financeiros e normalmente com menor tempo na propaganda gratuita no rádio e na televisão.

A constatação de que as eleições no Brasil se caracterizam pelo desequilíbrio da competitividade eleitoral pelo fator do poder econômico, em contrariedade ao ditame do art. 14, § $9^{\circ}$ da Constituição de 1988 - que determina a proteção da normalidade e da legitimidade das eleições contra a influência do poder econômico - advém de outras fragilidades do sistema normativo do financiamento da atividade política no Brasil.

Primeiramente, pode-se constatar que as campanhas eleitorais no Brasil são muito dependentes de recursos financeiros porque são caras. Neste trabalho, pressupõese que tal encarecimento deva-se às necessidades propagandísticas das campanhas na

\footnotetext{
3 Jairo Nicolau, "Notas sobre as eleições de 2002 e o sistema partidário brasileiro", in Cadernos Adenauer, ano IV, n. 1, 2003, p. 14.
} 
ordem vigente, em que os recursos publicitários e a contratação de especialistas nos mais diversos temas fazem os custos crescerem demasiadamente.

Ademais, há também um alto custo pelo fato de as circunscrições eleitorais brasileiras serem grandes. Na eleição presidencial, por óbvio, a circunscrição é nacional, fato este que pode acarretar elevados custos com transporte, distribuição de material de campanha e contratação de pessoal para os mais diversos locais do país, por exemplo. Nas eleições estaduais (governador, senador, deputado federal, deputado estadual ou distrital), em alguns casos a circunscrição, em se tratando de tamanho do território também é grande, gerando maiores custos como na eleição presidencial.

O fato de o sistema de eleição proporcional de lista aberta vigente no Brasil também ocasiona o aumento dos gastos das campanhas eleitorais. Esse sistema tem como conseqüência as disputas intrapartidárias, ou seja, além de ser importante para um candidato um grande número de votos ao seu partido/coligação, deve o candidato dirigir atenções ao fato de estar bem posicionado dentro da lista partidária ou da coligação, pois só assim conseguirá ser eleito para a Câmara dos Deputados ou para os Legislativos distrital, estaduais ou municipais. Em conseqüência, as candidaturas às eleições proporcionais também são individuais: com pequena presença do partido, os candidatos aos cargos proporcionais montam sua própria estrutura de campanha, administram e aplicam os recursos autonomamente, gerando maior necessidade de recursos.

Além disso, a própria dinâmica partidária nos dias atuais trouxe novos parâmetros para sua sobrevivência. Os partidos deixaram de ser representantes de apenas uma parte da camada social, como de uma classe ou de seguidores de uma ideologia. As legendas converteram-se em partidos mais flexíveis, programáticos, nacionalizados e com estrutura profissionalizada ${ }^{4}$. O fenômeno descrito gera novos custos, visto que as legendas buscam atingir eleitores do mais diversos tipos, diferentes dos que tradicionalmente são seus seguidores, havendo a necessidade de novos e mais profissionais especializados na contenda eleitoral.

\footnotetext{
${ }^{4}$ Cf. José Woldenberg. "Relevancia y actualidad de la contienda político-electoral", in Daniel Zovatto (coord.)et.all. Dinero y contienda político-electoral: reto de la democracia. México: Fondo de Cultura Económica, 2003, p. 19.
} 
Além dos aspectos legislativos referentes ao aumento dos gastos nas campanhas eleitorais, pode-se apontar como fragilidade do sistema de financiamento da atividade política a existência de brechas na legislação. Para citar um exemplo, o art. 27 da LE dispõe que os gastos realizados por eleitores para o seu candidato de preferência no valor de até mil UFIR não precisam constar da prestação de contas dos candidatos.

Este dispositivo legal constitui um autêntico paradoxo legislativo, já que a permissão em comento vai de encontro com o espírito da LE, que é a de dificultar a existência de irregularidades nas campanhas eleitorais e promover maior controle sobre as prestações de contas. Adriano Soares da Costa, ao comentar o artigo citado, faz dura crítica ao seu texto, conforme trecho a seguir:

Toda a estrutura de moralidade construída pela Lei, visando controlar a legalidade da receita e despesa dos comitês partidários, ruiu por terra com a adoção desse dispositivo. (...) Assim, os candidatos encontrarão nessa faculdade um meio de burla da legislação, atribuindo aos gastos pessoalmente realizados pelos eleitores certos gastos não computados, criando o mau vezo da legalização, ainda que indireta, de recursos recebidos por fora, sem contabilização ${ }^{5}$.(grifos nossos).

Outra omissão da legislação pode ser enfatizada aqui com base em reportagem do jornal Folha de S. Paulo veiculada na edição de 20 de novembro de 2006. A referida notícia detectou que na prestação de contas de diversos candidatos disponíveis no sítio do Tribunal Superior Eleitoral (TSE), não é possível identificar a origem de R\$ 66 milhões de reais doados às campanhas eleitorais nas últimas eleições.

A candidatura do ex-ministro da Saúde Humberto Costa ao governo de Pernambuco é utilizada como exemplo pelos jornalistas de como a falta de transparência nas contas eleitorais de alguns partidos e candidatos acarreta dificuldades aos eleitores em saber quem são os doadores e financiadores das campanhas de alguns postulantes. Na prestação de contas de Costa, $68 \%$ dos recursos recebidos têm origem desconhecida,

\footnotetext{
${ }^{5}$ Adriano Soares da Costa. Instituições de direito eleitoral. Belo Horizonte: Del Rey, 6. ed., rev., ampl. e atual., 2006, p. 753. No mesmo sentido, Vera Michels: "Penso que esse artigo dá azo à utilização abusiva do poder econômico, sem qualquer penalização, porque um candidato poderá receber inúmeras doações, de variadas pessoas, até mil UFIR, somando valores abusivos, e que não estarão sujeitos à contabilização, por força da própria lei eleitoral". (Vera Maria Nunes Michels. Direito eleitoral: de acordo com a Constituição Federal, LC 64/90, Lei 9.096/95 e Lei 9.504/97. 3. ed. rev. atual., Porto Alegre: Livraria do Advogado, 2004, p.188).
} 
já que vieram do Diretório Nacional de seu partido (o PT). Assim, o eleitor só pôde saber a origem de tal montante em 2007, quando o Partido dos Trabalhadores apresentou ao TSE seu balanço do ano de $2006^{6}$.

Este fato ilustra bem como as brechas da legislação podem facilitar a vida dos partidos e candidatos que não querem que suas contas eleitorais sejam transparentes para o controle e acompanhamento da sociedade brasileira. No caso ora discutido, o eleitor pernambucano só poderá saber quem doou recursos à campanha petista e como o candidato gastou este dinheiro meses depois da eleição (e eventualmente, algum tempo depois da posse do candidato, se vencedor da eleição). É forçoso reconhecer que neste caso a arrecadação de recursos de campanha não poderá servir de parâmetro para o eleitor escolher seu candidato.

A existência de algumas das brechas legislativas foi bastante ressaltada após o surgimento de escândalos de importância nacional nos quais o financiamento irregular de campanha era o principal elemento em questão.

O "mensalão", esquema de corrupção denunciado pelo ex-deputado federal Roberto Jefferson (PTB - Rio de Janeiro), consistia em repasses regulares de dinheiro para o chamado "caixa dois" de campanhas eleitorais de partidos e congressistas apoiadores do governo Luiz Inácio Lula da Silva em troca de apoio legislativo permanente às iniciativas do governo no Congresso.

Esse escândalo trouxe à tona algumas das fragilidades do sistema políticoeleitoral brasileiro, em especial o sistema normativo de financiamento da atividade política, fortalecendo os críticos da vigência do atual sistema misto com forte predominância privada.

É forçoso reconhecer que a denúncia do ex-deputado federal Roberto Jefferson apesar de espetaculosa, não foi considerada grande novidade para os estudiosos do cenário político brasileiro e também para os próprios políticos. Inúmeros casos e

\footnotetext{
${ }^{6}$ Cf. Rubens Valente e Leandro Beguoci; "Brecha legal oculta doadores de R 66 mi para campanhas", in Folha de S. Paulo, edição de 20.11.2006.
} 
exemplos de irregularidades no financiamento de partidos e de campanhas eleitorais já ocorreram no Brasil.

Vários casos célebres de irregularidades no financiamento de campanhas eleitorais no Brasil são relatados por Maurício Dias, como o aporte de dólares por meio do Instituto Brasileiro de Ação Democrática (Ibad) a candidatos "simpatizantes" dos Estados Unidos no início da década de 60 do século passado, as campanhas de Adhemar de Barros, Juscelino Kubitschek e Tancredo Neves, além do escândalo PC Farias Fernando Collor de Mello, que justificou gastos exorbitantes pessoais com "sobras da campanha de 1989" 7 .

David Samuels salienta o fato de que muitos só se dão conta da importância tanto do estudo do fenômeno quanto do aperfeiçoamento das normas referentes ao financiamento da atividade política no momento em que ocorrem escândalos flagrantes, como a denúncia contra a parceria PC Farias - Fernando Collor de Mello ou também em casos como o da então pré-candidata à Presidência pelo PFL Roseana Sarney, envolvida em denúncia recolhimento ilegal de divisas para sua campanha em $2002^{8}$.

O fortalecimento de instrumentos de controle que priorizem a transparência da administração financeira dos partidos políticos e das campanhas eleitorais deveria ser um dos fatores fundamentais para o combate às irregularidades no financiamento de campanhas eleitorais e dos partidos políticos no Brasil. Um melhor controle não só da arrecadação e dos gastos durante a eleição, mas também no momento de prestação de contas possibilitaria melhores informações para que os eleitores soubessem quem apóia financeiramente determinados candidatos.

O frágil controle no processo de julgamento das contas na Justiça Eleitoral é outro fator que leva à descrença do atual sistema em vigor, já que a verificação de irregularidades na prestação de contas de inúmeros candidatos e partidos políticos normalmente não é percebida pela Justiça Eleitoral. Essa debilidade dificulta a punição

\footnotetext{
${ }^{7}$ Cf. Maurício Dias. A mentira das urnas: crônica sobre dinheiro e fraudes nas eleições, Rio de Janeiro: Record, 2004, p. 117 ss.

${ }^{8}$ Cf. David Samuels. "Financiamento de campanha e eleições no Brasil: o que podemos aprender com o 'caixa um' e propostas de reforma”. In: Maria Victoria Benevides; Paulo Vanucchi; Fábio Kerche (orgs.); Reforma política e cidadania. São Paulo: Editora Fundação Perseu Abramo, 2003, p. 365.
} 
do candidato infrator, que aposta na lentidão do poder Judiciário para manter-se até o final de seu mandato.

Diante do quadro ora exposto, houve reação por parte dos três poderes, sendo que cada um apresentou suas propostas visando o aperfeiçoamento do regime de financiamento da atividade política no Brasil. Assim, foram apresentadas no Congresso Nacional diversas alternativas para a reforma normativa do financiamento da política no país, passando por alterações na legislação referente aos crimes eleitorais, às campanhas em si e também ao sistema eleitoral como um todo.

Já antes do "mensalão", vários projetos foram apresentados pelos congressistas com a intenção de ampliar o financiamento público de campanhas, que no sistema vigente é formado pelos recursos do Fundo Partidário (o financiamento público direto) e pela gratuidade da propaganda política e eleitoral no rádio e na televisão (financiamento público indireto).

Destaca-se também que alguns dos projetos pretendem tornar o sistema de financiamento hoje misto para um sistema exclusivamente de origem pública, extinguindo a possibilidade de haver doações de pessoas físicas e jurídicas privadas às campanhas eleitorais e aos partidos políticos.

A recente retomada da discussão sobre o modelo de financiamento de campanhas eleitorais e dos partidos políticos entre os estudiosos da política e entre os parlamentares só confirmou a importância de um sistema adequado de financiamento para o bom funcionamento da política em geral.

Segundo José Woldenberg, os partidos políticos se transformaram na coluna vertebral do Estado democrático, sendo que a sustentação financeira dessas agremiações é fundamental para garantir a democracia em sua plenitude. Segundo ele:

(...) não se exagera quando se refere ao financiamento dos partidos como um tema absolutamente central não só para os próprios partidos políticos e para sua 
influência, prestígio e implantação social, mas, o que é mais importante, para a legitimidade e a saúde do sistema democrático mesmo (tradução nossa) ${ }^{9}$.

Entre diversas propostas que constam nas comissões do Congresso Nacional foi aprovado um projeto de lei de autoria do então senador Jorge Bornhausen (PFL - Santa Catarina ${ }^{10}$ que se transformou na Lei $\mathrm{n}^{\circ}$. 11.300/2006, alcunhada de "minirreforma eleitoral".

As principais transformações propostas pelo senador catarinense foram: (i) diminuição do período de campanha de 90 para 60 dias; (ii) diminuição do período de veiculação da propaganda eleitoral gratuita no rádio e na televisão de 45 para 30 dias; (iii) proibição do uso de artistas em shows e propagandas partidárias; (iv) proibição da distribuição de brindes; (v) proibição do uso de propaganda eleitoral como outdoors, cartazes e afins, entre outras. As duas primeiras não foram aprovadas pelo Congresso Nacional, mas as outras três entraram em vigor já nas eleições de 2006.

Ao elaborar o projeto que deu origem à Lei nº $11.300 / 2006$, Bornhausen alegou que o uso do "caixa dois" no financiamento da política político ocorre por causa dos custos das campanhas, que crescem cada vez mais, mesmo sendo a propaganda eleitoral no rádio e na televisão veiculada gratuitamente ${ }^{11}$ (ao contrário de sistemas eleitorais de outros países, em especial os EUA, onde o sistema de propaganda pelo rádio e televisão é diametralmente diferente do brasileiro).

Ressalte-se que muitos afirmam que os custos de campanha no Brasil são muito altos em comparação aos EUA, país de tamanho territorial e populacional não muito diferente do brasileiro. Mas eles se esquecem de que o Brasil tem um sistema eleitoral completamente diferente do americano ${ }^{12}$, obrigando que os partidos e que os candidatos gastem mais em suas pretensões eleitorais.

\footnotetext{
${ }^{9}$ José Woldenberg. "Relevancia y actualidad de la contienda político-electoral”. p. 18.

${ }^{10}$ Projeto de Lei do Senado n. 275/2005, com texto inicial e respectiva Justificação disponível em:< http://legis.senado.gov.br/mate-pdf/6685.pdf>. Último acesso em 10.11.2009.

${ }^{11}$ Os partidos políticos não pagam pelas propagandas veiculadas no rádio e na televisão, mas as transmissoras são indenizadas pelo espaço cedido por meio de benefícios fiscais, caracterizando um verdadeiro financiamento público partidário e de campanhas eleitorais de forma indireta.

${ }^{12}$ Para exemplificar, podemos citar as eleições para a escolha de representantes na Câmara Baixa do Parlamento. Nos EUA, onde é aplicado o sistema majoritário, cada estado federado é dividido em distritos. Assim, o postulante só faz atos de campanha político no território distrital ao qual está
} 
Assim sendo, a Lei n. 11.300/2006 mudou os seguintes aspectos do financiamento de campanhas eleitorais no Brasil ${ }^{13}$ : (i) o responsável pela gestão financeira e pela prestação de contas das campanhas será indicado por um comitê financeiro do partido político, sendo o candidato solidariamente responsável; (ii) a descoberta de recursos não contabilizados acarreta a nulidade das contas e impugnação do registro de candidatura, se for comprovado que ocorreu abuso do poder econômico; (iii) a vedação da doação em dinheiro, sendo permitido somente por meio de depósito identificado ou em cheque cruzado; (iv) a proibição de as ONGs, as pessoas jurídicas sem fins lucrativos e as sociedades esportivas e beneficentes doarem recursos às campanhas; (v) a obrigatoriedade de o candidato disponibilizar duas prestações de contas parciais a serem apresentadas durante a campanha.

Conforme se pode averiguar, a Lei n. 11.300/2006 avançou pouco nas disposições que tratam das especificidades da arrecadação e prestação de contas de campanhas eleitorais, além de que alguns itens do projeto original foram rejeitados pelo Congresso e também por veto presidencial.

Surpreendentemente, após a promulgação dessa lei (que objetivava a diminuição dos gastos nas campanhas eleitorais), os custos da corrida eleitoral ao Congresso Nacional, ao Palácio do Planalto e para os governos estaduais aumentaram drasticamente.

Apesar de a lei proibir a produção de vários artefatos tradicionais nas campanhas eleitorais (canetas, camisetas, lixas de unhas), bem como a distribuição de brindes e haver também a vedação à propaganda eleitoral por meio de banners e outdoors e de "showmícios" (sendo tudo isso de grande custo para as campanhas eleitorais até 2004), as prestações de contas apresentadas à Justiça Eleitoral vieram quase sempre com gastos maiores que em $2002^{14}$.

vinculado. Já no Brasil, o distrito eleitoral para a eleição à Câmara dos Deputados é o próprio Estado, gerando a necessidade de fazer a campanha política em diversas regiões do estado.

${ }^{13}$ Cf. Adriano Soares da Costa. "Comentários à Lei no 11.300/2006".in Jus Navigandi, ano 10, n. 1107, 13 jul. 2006. Disponível em: <http://jus2.uol.com.br/doutrina/texto.asp?id=8641〉. Acesso em: 17 out. 2006.

${ }^{14}$ Em 2002, a campanha de Luiz Inácio Lula da Silva informou ter gasto em volta de R \$ 21 milhões na campanha, fora as despesas contabilizadas como do Comitê Financeiro conforme declaração ao TSE. Já 


\subsection{Metodologia}

O estudo a ser desenvolvido tratará de uma análise teórica do sistema eleitoral brasileiro, notadamente das normas e disposições eleitorais. A análise da legislação brasileira atual será fundamental para compreender as razões do modo de funcionamento atual do regime jurídico de financiamento da política.

Não obstante, há uma dimensão empírica, já que as próprias prestações de contas apresentadas à Justiça Eleitoral serão analisadas para que seja constatado quais são os tipos de gastos realizados pelos partidos durante o período não-eleitoral e também nas campanhas políticas.

Embora muitos acreditem que essas prestações de contas sejam verdadeiras "peças de ficção"15, pelo fato de o uso de "caixa dois" ser bastante disseminado nas eleições, as prestações de contas apresentadas à Justiça Eleitoral são instrumentos válidos para entender melhor o sistema de financiamento político brasileiro, já que com elas podemos partir para o estudo não só do perfil dos financiadores (assim, analisando quem financia por meio do "caixa 1"), mas também do tipo de gastos realizados durante as campanhas eleitorais.

Além disso, ao analisá-las, percebe-se que as fontes de doações normalmente são de empresas "fortemente afetadas pela regulação governamental ou altamente dependentes de contratos com o governo". Esse fato sugere que as prestações de contas são instrumentos válidos de pesquisa, eis que se elas fossem completamente falsas, tal

em 2006, foi informado que a nova campanha vitoriosa de Lula teve como total de despesas um valor de R \$ 91 milhões, sem incluir novamente a prestação de contas do Comitê Financeiro. A explosão nos gastos de campanha também pode ser verificada no confronto entre as campanhas presidenciais do PSDB: a de José Serra custou aproximadamente R \$ 35 milhões, em 2002 e a de Geraldo Alckmin R \$ 79 milhões, em 2006.

${ }^{15}$ Fernando Rodrigues destaca o fato de nas prestações de contas dos deputados federais (total de 19 parlamentares) envolvidos no escândalo do "mensalão", em 8 delas houve coincidência no valor arrecadado e no valor gasto, "inclusive nos centavos depois da vírgula". Destaca também que entre os 1.790 políticos eleitos em 2002, "o valor total das receitas para a campanha eleitoral foi de R $\$ 397,1$ milhões. As despesas ficaram em R \$ 396,9 milhões", portanto, números praticamente idênticos. O autor classifica esse fenômeno como "coincidência improvável". (Fernando Rodrigues, Políticos do Brasil, São Paulo: Publifolha, 2006, p. 129). 
afirmação não poderia ser realizada, sendo que os dados seriam apenas "um mero conjunto aleatório de números" $" 16$.

Da mesma forma, pode-se analisar as campanhas eleitorais mais a fundo: as prestações de contas apresentadas à Justiça Eleitoral; as despesas regulares; quais são os reais gastos (transporte, funcionários, propaganda, etc.) durante uma campanha eleitoral. Somente com uma análise desse tipo pode-se averiguar a real necessidade de mudanças tanto no tempo da campanha como na vedação de certos aspectos da atual campanha eleitoral e sua influência nas finanças da corrida à eleição.

\subsection{Plano do trabalho}

Após a presente introdução, capítulo em que foram enfatizadas as bases iniciais do tema a ser desenvolvido e sua importância dentro do contexto político-eleitoral brasileiro, além de explanada a metodologia deste trabalho, haverá mais cinco capítulos, que serão divididos na forma a ser explicada a seguir.

O Capítulo 2 contém análise referente aos principais problemas apontados pelos estudiosos do panorama político-eleitoral brasileiro que guardem relação, direta ou indiretamente, com a normatização do sistema de financiamento da política no Brasil.

Assim sendo, esse diagnóstico conterá: (i) análise do sistema de eleição proporcional, com ênfase nas coligações partidárias e no fenômeno da individualização das candidaturas; (ii) exame do sistema partidário brasileiro, com destaque ao instituto da fidelidade partidária, à disciplina partidária e ao pluripartidarismo brasileiro caracterizado pelo grande número de partidos existentes no país; (iii) estudo das campanhas eleitorais, com exame da importância do horário eleitoral gratuito e da presença do marketing político-eleitoral; e (iv) identificação das principais críticas relacionadas ao sistema normativo do financiamento da política no Brasil

\footnotetext{
${ }^{16}$ David Samuels, "Financiamento de campanha e eleições no Brasil: o que podemos aprender com o 'caixa um' e propostas de reforma", p. 367.
} 
O capítulo também contém um debate sobre as principais propostas existentes no Congresso Nacional que tratam da reforma do contexto político brasileiro, todas elas contendo também propostas para reformar o financiamento dos partidos políticos e das campanhas eleitorais no país, com o interessante fato de cada uma delas ser a resposta institucional de cada poder do Estado brasileiro aos problemas da conjuntura políticoeleitoral brasileira.

Serão abordadas, portanto, a proposta elaborada pela Comissão Especial de Reforma Política da Câmara dos Deputados; o projeto de lei preparado pela Comissão de Notáveis instituída pelo TSE e os projetos de lei apresentados ao Congresso Nacional pela Secretaria de Assuntos Legislativos do Ministério da Justiça em fevereiro de 2009. Por fim, há um debate sobre as vantagens e as desvantagens do sistema público de financiamento da política e do financiamento privado.

No capítulo 3 será tratado todo o corpo normativo vigente no Brasil que aborda o tema do financiamento da atividade política no Brasil. Há análise dos ditames previstos na Lei das Eleições (Lei n. 9.504/97), na Lei dos Partidos Políticos (Lei n. 9.096/95), na Lei das Inelegibilidades (Lei Complementar n. 64/90) e no Código Eleitoral (Lei n. 4.737/65). Ganham destaque nesse capítulo também as normas referentes aos convênios firmados entre o TSE e outros órgãos do Poder Público no sentido de controlar e fiscalizar eventuais irregularidades cometidas pelos partidos ou pelos candidatos.

O capítulo 4 consiste numa pesquisa empírica nas prestações de contas apresentadas à Justiça Eleitoral.

Estão disponíveis no site do TSE todas as prestações de contas desde a eleição de 2002, inclusive. Serão analisadas contas prestadas pelos candidatos ou pelos seus comitês para a verificação dos seguintes preceitos: (i) como e no que são feitas as despesas eleitorais; (ii) se realmente há no Brasil uma predominância das doações de pessoas jurídicas para as campanhas eleitorais; (iii) se o ritmo das doações cresce para os candidatos que se destacam nas pesquisas eleitorais (e também o contrário, ou seja, se as doações mínguam após uma queda brusca e/ou permanente do candidato nas pesquisas de intenção de voto; e (iv) se realmente houve diferença nos custos das 
campanhas após o advento da Lei n. 11.300/2006, norma esta que visava à queda no preço das campanhas eleitorais.

Disto, poder-se-á chegar a uma conclusão sobre se as campanhas realmente são caras (a crítica neste tema é a de que não há tanta necessidade de dinheiro assim) ou se o sistema eleitoral brasileiro impõe na prática que o candidato gaste seu dinheiro em matérias de campanhas eleitorais específicas (exemplo, transporte e gastos com rádio e TV), fazendo com que as campanhas sejam "necessariamente" mais caras. Serão estudadas, portanto, as prestações de contas das eleições à Presidência da República nas eleições de 2002 e 2006.

Por fim, o Capítulo 5 trará as considerações finais a serem feitas neste trabalho, seguida da Bibliografia, que contém todas as obras citadas neste trabalho. 


\section{SISTEMA POLÍTICO-ELEITORAL BRASILEIRO: SUAS FRAGILIDADES E OS POSSÍVEIS REMÉDIOS}

\subsection{Fragilidades do sistema político-eleitoral brasileiro}

O sistema político-eleitoral brasileiro, conforme apresentado na introdução deste trabalho, é apontado como atrasado e retrógrado, além de absolutamente instável por quase todos os seus estudiosos. Por isso, o cenário político brasileiro é duramente criticado pelos seus principais atores (os políticos) e pela sociedade em geral. Entre os mais diversos exames referentes ao sistema em seus mais variados aspectos, surge o problema do financiamento da atividade política, foco principal deste trabalho.

O país vive já há algum tempo uma onda de escândalos políticos, citando-se como exemplo, os "mensalões" do Partido dos Trabalhadores no Congresso Nacional, do Partido da Social Democracia Brasileira no estado de Minas Gerais, ambos surgidos em 2005 e o do Democratas no Distrito Federal surgido em novembro de 2009; além de denúncias de malversação do dinheiro público por parte de congressistas e do crescimento exacerbado da estrutura administrativa das Casas Legislativas, para citar os mais recentes.

Alega-se, conforme ser verá neste trabalho, que o quadro existe em virtude da falta de regras rigorosas para um melhor funcionamento do cenário político-eleitoral nacional. Especialistas apontam que dentre os mais diversos problemas, conforme apontamento feito na introdução deste problema, o mais grave é o financiamento da atividade política no Brasil.

Diante desse panorama, muitas propostas surgiram não só no Congresso Nacional, mas também no Poder Judiciário e no Poder Executivo com o intuito de aprimorar o sistema político-eleitoral brasileiro como um todo, sendo alguns projetos especialmente dedicados à reforma do sistema normativo do financiamento da política brasileiro. 
Para uma análise profunda dos aspectos do financiamento da política no Brasil escopo deste trabalho - é fundamentalmente necessária a apreciação, o entendimento das principais fragilidades do sistema eleitoral brasileiro, para que se possa compreender em que contexto está inserido o financiamento dos partidos políticos e das campanhas eleitorais brasileiras e se há relação entre a questão do financiamento da política com outros pontos considerados nevrálgicos da política brasileira.

Entre as mais diversas fragilidades apontadas pelos especialistas na área e debatidas neste capítulo, pode-se citar inicialmente o sistema partidário brasileiro. Os partidos políticos brasileiros em grande parte sofrem, por exemplo, com a infidelidade partidária, ou seja, a possibilidade de o político exercendo seu mandato trocar de partido.

O texto constitucional deixou de prever a punição da perda de mandato para o político que trocasse de partido durante o exercício do mandato com a promulgação da Emenda Constitucional n. 25, de 15 de maio de 1985. A Constituição da República de 1988 também não contém esta previsão, permitindo aos próprios partidos políticos estabelecer normas em seu estatuto sobre eventual infidelidade (art. 17, $\S 1^{\circ}$ ).

No entanto, provocado por partidos políticos prejudicados com essas trocas, o Tribunal Superior Eleitoral editou a Resolução TSE n. 22.610, de 25 de outubro de 2007 disciplinando a perda do cargo eletivo em caso de desfiliação partidária e os casos nos quais há a permissão para a troca de partido. Referida Resolução foi contestada no Supremo Tribunal Federal, que confirmou sua constitucionalidade, conforme veremos adiante. Porém, no final do prazo de filiação partidária para que o indivíduo possa concorrer nas eleições de 2010, percebeu-se que houve muitos congressistas que resolveram mudar de partido, encarando assim o risco de perderem o mandato, em possível confronto com as disposições da referida Resolução.

O grande número de partidos registrados no TSE (vinte e sete ao todo ${ }^{17}$ ) também é visto por muitos estudiosos como outro aspecto negativo do sistema político-eleitoral brasileiro.

\footnotetext{
17 Lista dos partidos políticos registrados no TSE disponível em: <http://www.tse.jus.br/internet/partidos/index.htm>. Último acesso em $1^{\circ} .11 .2009$.
} 
A quantidade de agremiações com possibilidade de apresentar candidatos a qualquer tipo de disputa eleitoral (e também com direito aos recursos públicos do Fundo Partidário que servem não só para sua manutenção, mas também para suas campanhas eleitorais), sem contar com o acesso à propaganda partidária e eleitoral gratuita veiculada nas rádios e na televisão de todo o Brasil é criticada principalmente pelo fato de os partidos terem pouca capilaridade na sociedade brasileira, com poucos filiados e em sua maioria com resultados eleitorais pífios, ao ponto de serem titulados pela imprensa e pelos acadêmicos como "partidos nanicos".

Ademais, a grande quantidade de partidos é também apontada como um dos principais fatores para uma possível "ingovernabilidade", ou seja, o fato de haver muitos partidos disputando as eleições e conseqüentemente nas Casas Legislativas acarreta dificuldade para o mandatário do poder executivo aprovar seus projetos, o orçamento anual e também suas políticas públicas.

O sistema eleitoral de lista aberta nas eleições proporcionais é outro aspecto criticado pelos estudiosos e pelos acadêmicos, já que sua principal conseqüência é a existência de candidaturas individuais para o cargo almejado (candidaturas estas praticamente independentes, tanto na infra-estrutura como na arrecadação e administração dos recursos financeiros), gerando assim uma disputa fratricida entre candidatos do mesmo partido político ou da mesma coligação durante o período eleitoral. Essa questão é classificada por Fabiano Santos, por exemplo, como crucial para o sistema brasileiro de representação política ${ }^{18}$.

Especialistas também argumentam, conforme se verá adiante, que o fato de as campanhas para os pleitos proporcionais serem individuais determina também o enfraquecimento dos partidos, pois os candidatos pouco dependem das agremiações durante a campanha e quando eleitos tendem a agir com mais independência no curso do mandato.

\footnotetext{
${ }^{18}$ Cf. Fabiano Santos, "Reformas políticas na presidência de Fernando Henrique Cardoso", in Cadernos Adenauer, ano III, n. 3, 2002, p. 29.
} 
As campanhas eleitorais também são alvo de crítica para os especialistas e políticos. Argumenta-se que o período de campanha é muito longo, tornando as campanhas muito caras, ou seja, com forte dependência do capital privado para a arrecadação e para a administração da campanha.

Há também a grande dependência das campanhas eleitorais do horário eleitoral gratuito, fato este que motiva os candidatos a procurarem profissionais do marketing político-eleitoral, procura essa arraigada na cultura política brasileira. Os marqueteiros, como são chamados os profissionais da área, por vezes procuram utilizar-se de "artifícios" publicitários e são bastante dependentes de pesquisas de opinião para a realização de seu trabalho, aumentando ainda mais os gastos eleitorais.

Por fim, vem à tona o financiamento dos partidos políticos e das campanhas eleitorais no Brasil. Em função de todos os problemas acima discutidos, as campanhas cada vez mais têm a necessidade de maior arrecadação de dinheiro. Em consequiência, as principais candidaturas são fortemente dependentes do apoio privado, em que pese o horário eleitoral gratuito.

A forte dependência de dinheiro com origem privada traz a possibilidade de atos de abuso do poder econômico e também de influência de financiadores de campanha em atos do legislador ou do mandatário financiado em sua campanha.

Diante deste diagnóstico do sistema político-eleitoral brasileiro, foram apresentados diversos antídotos, sendo que alguns projetos são pontuais, ou seja, tratam de apenas um dos aspectos apontados como fragilidades do sistema, e outros mais extensos, aventando diversos dispositivos do sistema.

Assim, serão tratados neste capítulo os três projetos nomeados de "reforma política", por abordarem várias das fragilidades acima apontadas, sendo que as três propostas têm entre seus objetivos a reforma normativa do financiamento da política no Brasil. Referidos projetos de reforma política têm origem nos três poderes da República, sendo que o primeiro a ser analisado é a proposta feita pela Comissão Especial de Reforma Política da Câmara dos Deputados, concluída em 2003. 
O segundo projeto foco de análise neste capítulo foi elaborado por uma Comissão de Notáveis formada pelo Tribunal Superior Eleitoral, grupo este constituído logo após o surgimento do escândalo do “mensalão”, em meados do ano de 2005.

Por fim, será debatido o projeto de reforma política criado pela Secretaria de Assuntos Legislativos do Ministério da Justiça, apresentado à sociedade em 2008 e enviado ao Congresso Nacional em fevereiro de 2009.

Após, serão estudados também os projetos pontuais sobre o financiamento da política no Brasil, ou seja, propostas que tenham como foco não só algum dispositivo legal diretamente ligado ao sistema normativo do financiamento dos partidos ou das campanhas eleitorais, mas também as propostas que mudam algum dispositivo que afete indiretamente a questão, como, por exemplo, mudança na propaganda eleitoral que possa ter como consequiência crescimento ou diminuição dos gastos de campanha.

\subsubsection{Sistema proporcional em lista aberta}

O sistema eleitoral para a escolha de candidatos aos cargos de vereador, deputado distrital, deputado estadual e deputado federal no Brasil é do tipo proporcional, conforme prevê o art. 45, caput da Constituição da República e os arts. 84 e 105 a 113 do CE.

Esse sistema tem como principais objetivos assegurar que a diversidade de opiniões da sociedade esteja refletida na respectiva Casa Legislativa e garantir eqüidade matemática entre o voto do eleitorado e a representação parlamentar, tendo como principal virtude o fato de espelhar aritmeticamente no Legislativo as preferências da sociedade, procurando garantir correspondência entre os votos recebidos e o número de cadeiras dos partidos em uma eleição ${ }^{19}$.

Há, porém, críticas a esse tipo de sistema. Jairo Nicolau enfatiza que o sistema proporcional enfatiza demasiadamente a representação, em detrimento à possibilidade de o governo formar maioria no Legislativo. Dificilmente o sistema proporcional

\footnotetext{
${ }^{19}$ Jairo Nicolau. Sistemas eleitorais: uma introdução. Rio de Janeiro: Editora FGV, 4. ed., 2002, p. 31.
} 
proporciona ao partido do governo a maioria absoluta de cadeiras no Legislativo, ocasionando a necessidade de formar maioria por meio de acordos pós-eleitorais para que uma base de sustentação parlamentar seja formada.

Além disso, na eleição proporcional é necessário formar o distrito, a circunscrição eleitoral. No caso das eleições para as Assembléias Legislativas, Câmara Legislativa do Distrito Federal e para a Câmara dos Deputados, a circunscrição é o próprio estado. Já nas eleições legislativas municipais, o distrito eleitoral é o próprio município. Distritos muito grandes com um número grande de representantes fazem com que haja uma menor conexão entre os eleitores e os representantes, dificultando assim tanto a reeleição de parlamentares supostamente eficientes quanto a rejeição de legisladores aparentemente menos atuantes ou envolvidos em algum tipo de escândalo ${ }^{20}$.

No Brasil, utiliza-se a fórmula da lista aberta, ou seja, cabe aos eleitores decidirem quais os candidatos de cada partido que ocuparão os postos conquistados pelas agremiações. No sistema de lista fechada, proposto para vigorar no Brasil pela Comissão Especial de Reforma Política da Câmara dos Deputados (que será estudada adiante), os partidos, em convenção anterior ao período de propaganda eleitoral, escolheriam a sua ordem de candidatos, cabendo ao eleitor votar somente no partido, inexistindo a possibilidade de votar em um candidato individualmente.

O sistema de lista aberta, utilizado no Peru, Chile, Finlândia, Polônia e Brasil ${ }^{21}$, traz conseqüências ao sistema eleitoral como um todo, principalmente ao sistema partidário e ao financiamento das campanhas eleitorais. Para uma melhor análise do assunto, há uma divisão em dois subitens: as coligações partidárias e as candidaturas individuais. Esses dois temas serão analisados separadamente a seguir.

\footnotetext{
${ }^{20}$ Jairo Nicolau. Sistemas eleitorais, p. 57.

${ }^{21}$ Jairo Nicolau, Sistemas eleitorais, p. 50.
} 


\subsubsection{Coligações partidárias nas eleições proporcionais}

A possibilidade de partidos políticos coligarem-se para as eleições proporcionais, conforme prevê o art. 105 do $\mathrm{CE}$, não é exclusividade do sistema brasileiro. Mas essa possibilidade apresenta uma singularidade: no Brasil, forma-se no momento da apuração dos votos uma única lista de candidatos da coligação, sendo os candidatos mais votados da coligação os que ocuparão as cadeiras conseguidas pela aliança partidária. Na Polônia e na Finlândia, países em que há também a possibilidade de coligações partidárias nos pleitos proporcionais, as listas são unidas somente quando há a distribuição de cadeiras, ou seja, cada partido coligado recebe o número de cadeiras proporcional ao seu número de votos para a coligação ${ }^{22}$.

Exemplificando: na Polônia, os partidos ABC e DEF coligam-se e conseguem 10 cadeiras, sendo que o partido ABC teve $60 \%$ dos votos e o DEF conseguiu $40 \%$ dos votos dados à coligação. Assim, o partido $\mathrm{ABC}$ terá seis cadeiras e o DEF terá quatro postos no Legislativo polonês.

Em contraste, no Brasil, a coligação mitiga a relação do candidato com seu partido. A crítica na coligação partidária nas eleições proporcionais consiste no fato apontado acima por Jairo Nicolau como singularidade: a inexistência de um mecanismo intracoligação. Sem esse mecanismo, a distribuição de cadeiras entre os partidos pertencentes à coligação não tem qualquer relação com o número de votos obtido por cada partido.

Exemplificando: a coligação entre os partidos FGH e MNO alcança dez cadeiras, sendo que cada partido contribuiu com $50 \%$ dos votos para a coligação. No entanto, entre os dez postulantes mais votados da coligação (independentemente da ordem de posicionamento entre esses dez), nove são do FGH e um do MNO. São estes dez aqueles que serão diplomados pela Justiça Eleitoral e tomarão posse na Casa Legislativa no ano seguinte ao da eleição.

\footnotetext{
${ }^{22}$ Jairo Nicolau. Sistemas eleitorais, p. 53.
} 
Segundo a regra brasileira (arts. 106 a 108 do CE), apesar da contribuição igual dos partidos para a votação da coligação, o que vale é a ordem de votação individual dentro da coligação.

Jairo Nicolau lembra-se de outro problema grave que tal sistema suscita: com a possibilidade do voto na legenda, um eleitor pode votar na legenda para ajudar a eleger candidatos de seu partido. No entanto, na prática, o voto será contabilizado, se o partido participar de uma coligação na eleição proporcional, apenas para definir o total de cadeiras obtido pela coligação ${ }^{23}$. Fabiano Santos ressalta que o sistema brasileiro vigente pressupõe a existência de um sistema de partidos, eis que o voto dado por um eleitor a um determinado candidato contribui para a votação de um candidato do mesmo partido. Assim sendo, o eleitor não está apenas votando em seu candidato, mas também no partido a que o candidato é filiado ${ }^{24}$.

Tal regra permite a distorção na proporcionalidade almejada pela Constituição da República, já que partidos que obtiveram expressiva votação podem eleger poucos ou até nenhum representante, se estiverem em coligação. Muitos votos são na prática inutilizados ou têm seu valor diminuído com tal regra do CE. José Antônio Giusti Tavares critica esta regra prevista na legislação brasileira, conforme trecho a seguir:

Nem o eleitor nem o partido têm qualquer controle sobre o destino do voto e sobre a ordem de precedência dos candidatos nessa lista (...). Associado à prática de alianças partidárias em eleições proporcionais, esse mecanismo gera migrações de votos ainda mais aleatórias e irracionais, como resultado das quais os votos num partido terminam sendo contabilizados para outro partido ${ }^{25}$.

Além do mais, as coligações dão aos partidos menores maiores possibilidades de conseguir vagas nas Casas Legislativas, pois se sozinhos teriam problemas para atingir o quociente eleitoral, coligando-se conseguiriam muito mais facilmente alcançar o quociente e talvez eleger algum de seus candidatos.

\footnotetext{
${ }^{23}$ Cf. Jairo Nicolau. Sistemas eleitorais, p. 57.

${ }^{24}$ Cf. Fabiano Santos, Fabiano Santos, "Reformas políticas na presidência de Fernando Henrique Cardoso", p. 35.

${ }^{25}$ José Antônio Giusti Tavares. Sistemas eleitorais nas democracias contemporâneas: teoria, instituições, estratégia. Rio de Janeiro: Relume-Dumará, 1994, p. 128.
} 
Havendo maior possibilidade de partidos pequenos conseguirem cadeiras na Câmara dos Deputados, esses partidos terão maior tempo no horário partidário gratuito $^{26}$, no horário eleitoral gratuito ${ }^{27}$. Também disporão de maior verba no Fundo Partidário $^{28}$, além de obter maior poder de barganha nas coligações para as eleições majoritárias pois terão um tempo maior no horário eleitoral gratuito (esse fenômeno será analisado no item 2.1.3), quadro esse que incentiva ainda mais a criação de novos partidos inflando o sistema partidário brasileiro com as consequiências que serão estudadas no item 2.1.2.

\subsubsection{Candidaturas individuais}

Outro fenômeno que caracteriza o sistema eleitoral proporcional de lista aberta brasileiro é a existência de candidaturas individuais. Conforme estudado no item anterior, para ser eleito, não basta ao candidato somente que seu partido ou coligação consiga o maior número de votos.

Há a necessidade do candidato não só lutar contra os outros partidos, mas também concorrer diretamente contra seus colegas de partido ou de coligação. Se o candidato não estiver bem posicionado dentro da lista de votação de seu partido/coligação, ele terá poucas chances de ser eleito. Pode-se explicar resumidamente este fenômeno do sistema proporcional de lista aberta com o trecho de Jairo Nicolau exposto a seguir:

O sistema proporcional de lista aberta gera dois padrões de competição nas eleições. Um deles é a competição entre partidos pelas cadeiras parlamentares, outro é a disputa entre as candidaturas individuais de cada lista pelas possíveis cadeiras conquistadas. A disputa entre os candidatos de um mesmo partido deve-se à lógica e ao ambiente de incerteza que presidem a competição: a alocação

\footnotetext{
${ }^{26}$ O art. 48 da LPP (Lei n. 9.096, de 19 de setembro de 1995) prevê que o partido que não tem representação na Câmara dos Deputados terá dois minutos por semestre para sua propaganda partidária. Já os partidos que têm representação na Câmara têm 120 minutos por semestre, sendo 60 minutos em cadeia nacional e os outros sessenta em cadeira estadual para sua propaganda partidária (Art. 49 da LPP). ${ }^{27} \mathrm{O}$ art. 47, $\S 2^{\circ}$ da LE (Lei n. 9.504, de 30 de setembro de 1997) dispõe que o horário eleitoral gratuito é dividido da seguinte forma: um terço do tempo é dividido igualitariamente entre os partidos registrados no TSE e dois terços são divididos entre os partidos com representação na Câmara dos Deputados, proporcionalmente ao número de cadeiras de cada partido, observando-se o resultando da última eleição.

${ }^{28}$ Conforme art. 41-A da LPP, o Fundo Partidário é distribuído da seguinte forma: 5\% dos recursos são divididos igualmente entre todos os partidos registrados no TSE, e 95\% são distribuídos proporcionalmente à votação obtida para a Câmara dos Deputados.
} 
intralista é feita pelo método majoritário (os mais votados se elegem) sem que se saiba previamente quantos cargos estão em disputa (o número de cadeiras que o partido elegerá $)^{29}$.

Com esse fenômeno, as campanhas para as eleições proporcionais tendem a ter caráter individual, ou seja, separadas das campanhas do próprio partido e dos outros postulantes às vagas no Legislativo. Os partidos, segundo Luís Virgílio Afonso da Silva, tornam-se meros "veículos para que alguns políticos possam se eleger, independente de posições ideológicas e programas partidários" ${ }^{\text {30 }}$.

Este processo de individualização das candidaturas caracteriza-se pela administração da candidatura ser feita por pessoa indicada pelo candidato ou pelo próprio, com pequena ou nenhuma influência do partido. Ademais, sendo a administração da campanha feita desta forma, a arrecadação e a aplicação dos recursos financeiros também é responsabilidade do candidato ou de pessoa de sua confiança, além da propaganda eleitoral (fora a do horário eleitoral gratuito, esta sim coordenada pelos partidos), com contratação de cabos eleitorais, formação de comitê eleitoral, aluguel de carros de som, produção de santinhos ficando toda sob responsabilidade do administrador da campanha ou do candidato.

Toda essa estrutura de campanha individualizada acarreta em maior dependência de dinheiro para seu financiamento, possibilitando também maior influência do financiador sobre o candidato se eventualmente eleito. Há também um prejuízo ao trabalho da Justiça Eleitoral no período de análise de prestação de contas eleitorais, já que terá milhares de contas a serem analisadas ao invés de somente julgar contas partidárias após o período de propaganda eleitoral.

Além do fato de as candidaturas para as eleições proporcionais individualizadas aumentarem os gastos nas campanhas eleitorais, elas também enfraquecem os partidos políticos. José Antonio Giusti Tavares faz dura crítica a este fenômeno, conforme trecho a seguir:

\footnotetext{
${ }^{29}$ Jairo Nicolau, Sistemas eleitorais, p. 51.

${ }^{30}$ Cf. Luís Virgílio Afonso da Silva. Sistemas eleitorais, p. 161.
} 
Inconsistente com o espírito e com a técnica da representação proporcional, o voto único em candidatura individual tem sido o responsável pela competição voraz entre os candidatos de um mesmo partido que tão profundamente compromete, precisamente nos processos eleitorais, a identidade, a coesão e a disciplina internas dos partidos políticos na república brasileira ${ }^{31}$.

Luís Virgílio Afonso da Silva ressalta que por ter sido eleito sem a ajuda estrutural ou financeira de seu partido, terá o candidato poucas razões para ser leal à legenda após ser eleito, além de durante a campanha firmar compromissos e estreitar laços diferentes daqueles feitos pelos outros candidatos ou pelos próprios partidos ${ }^{32}$.

Estudados os principais aspectos referentes ao sistema proporcional brasileiro, tratar-se-á no item seguinte do sistema partidário brasileiro.

\subsubsection{Sistema partidário brasileiro}

Tratadas as críticas concernentes ao sistema eleitoral proporcional de lista aberta, será focado neste item outro aspecto apontado pelos especialistas e também por políticos como problemático no sistema político-eleitoral brasileiro: os partidos políticos.

No item anterior, foi discutida a fragilidade do partido político em relação aos seus filiados durante o período de campanha eleitoral, já que o sistema proporcional de lista aberta brasileiro cria condições para que o postulante tenha uma candidatura praticamente independente, dependendo do partido político apenas para ser selecionado para disputar as eleições ${ }^{33}$ e também para ter acesso a um tempo mínimo no horário eleitoral gratuito.

Neste item, será focalizada a relação entre os partidos políticos e seus filiados já eleitos, ou seja, aqueles que detêm cargos no poder Legislativo ou no Executivo. Para tal estudo, haverá uma divisão em dois subitens: o primeiro tratará da infidelidade

\footnotetext{
${ }^{31}$ José Antônio Giusti Tavares. Sistemas eleitorais nas democracias contemporâneas, p. 127.

${ }^{32}$ Cf. Luís Virgílio Afonso da Silva. Sistemas eleitorais, p. 162.

${ }^{33}$ Jairo Nicolau. Sistemas eleitorais, p. 51.
} 
partidária, fenômeno este que cuja existência é apontada como um dos principais problemas existentes na política brasileira, e o segundo tratará da existência ou não de uma proliferação exagerada de partidos no Brasil..

Com relação à infidelidade partidária, até o advento da Resolução TSE n. 22.610, de 25 de outubro de 2007, havia no Brasil a possibilidade de o indivíduo detentor de mandato político sair do seu partido durante o exercício do mandato sem qualquer tipo de penalidade, desde que respeitasse o fato de a legislação obrigar o candidato a ser filiado por pelo menos um ano para poder se candidatar (art. 18 da LPP e art. $9^{\circ}$ da LE). Tal possibilidade, conforme análise adiante tem como consequiência o descrédito dos partidos políticos perante a sociedade, fragilizando-os ainda mais.

Após a aprovação da referida Resolução e da confirmação de sua constitucionalidade pelo $\mathrm{STF}^{34}$, o número de políticos que mudaram de partido diminuiu. Porém, ainda existem casos em que o político troca de partido, inclusive com a permissão do TSE.

Já com relação a excessiva proliferação de partidos, cabe destacar que o quadro partidário brasileiro é composto atualmente de vinte e sete partidos registrados no TSE, ou seja, agremiações que podem lançar seus filiados para qualquer tipo de eleição (nacional, estadual, distrital ou municipal) e que têm acesso ao horário partidário e eleitoral gratuito, além de administrar recursos públicos provenientes do Fundo Partidário.

Diante da questão, o legislador havia encontrado a solução, determinando que os partidos que não obtivessem certa quantidade de votos nas eleições realizadas em outubro de 2006 para a Câmara dos Deputados não tivessem direito ao funcionamento parlamentar. O fato, porém, é que o STF declarou tal dispositivo da LPP inconstitucional, conforme será analisado no segundo subitem.

\footnotetext{
${ }^{34}$ ADI 3.999 e 4.086, j. 12.11.2008. DJE 17.6.2009, Rel. Min. Joaquim Barbosa.
} 


\subsubsection{Infidelidade e indisciplina partidárias}

A infidelidade e a indisciplina partidárias são dois dos mais graves problemas do sistema partidário brasileiro, pois têm como principal conseqüência a fragilização dos partidos tanto no âmbito interno como no externo.

Internamente, muitos partidos sofrem com uma redução no número de representantes nas Casas Legislativas, principalmente quando estão no papel de opositor ao poder executivo. Externamente, perante a sociedade em geral, a mudança desenfreada de partidos por parte dos membros do poder Legislativo traz a impressão de que todas as legendas são fracas, com coesão ideológica anêmica, gerando na população a opinião corrente de que os políticos pensam somente em seus interesses próprios e não no "interesse maior" que é o fortalecimento do partido e até do país conseqüentemente.

Há também o fato de que como no Brasil vige o sistema proporcional de lista aberta, o voto dado a um candidato também foi dado ao seu partido. Ao mudar de legenda, o político está contrariando a lógica do sistema proporcional vigente, eis que o mandato não é exclusivamente seu, mas também da legenda em qual estava filiado no momento da eleição ${ }^{35}$.

Ao analisar o tema, Carlos Ranulfo Melo afirma que tal fenômeno é importante e endêmico, gerando diversas conseqüências ao sistema político-eleitoral brasileiro, conforme trecho adiante:

Transformada em prática corrente, a troca de legenda passou a vigorar como instrumento suplementar de modificação da correlação de forças no Congresso, com impacto diferenciado sobre o desempenho dos sistemas partidários estaduais, a constituição das coalizões governamentais e o grau de representatividade do sistema partidário nacional. Tornou-se ainda, na medida em que ganhou destaque na mídia, parte do rol de atividades que, na percepção da população, contribuem para situar o Congresso e os partidos nos últimos lugares em qualquer pesquisa que se faça acerca da credibilidade das instituições no país. ${ }^{36}$.

\footnotetext{
${ }^{35}$ Cf. Fabiano Santos, "Reformas políticas na presidência de Fernando Henrique Cardoso", p. 35.

36 Carlos Ranulfo Melo. "Migração partidária na Câmara dos Deputados: causas, conseqüências e possíveis soluções", in Maria Victoria Benevides, Paulo Vannuchi e Fábio Kerche (orgs.), Reforma política e cidadania. São Paulo: Editora Fundação Perseu Abramo, 2003, p. 322.
} 
$\mathrm{O}$ autor afirma que o desenvolvimento do sistema partidário desde o fim de bipartidarismo forçado do regime militar (1979), passando por um pluralismo moderado (1979-1985) para o pluripartidarismo exacerbado existente desde então fez com que não houvesse no Brasil a identificação da maior parte do eleitorado com algum partido de sua preferência. Diante disso, segundo o autor, começou a surgir um cenário em que a mudança de partido passou a ser uma operação de baixo custo político frente ao eleitorado. Outro fator apontado pelo autor é o crescimento do número de partidos no cenário eleitoral desde 1985, pois foram criadas condições legislativas para tanto, entre elas: (i) a desnecessidade do registro definitivo no TSE para que os partidos pudessem disputar qualquer eleição; (ii) o retorno das coligações nas eleições proporcionais (ambas condições trazidas pela Lei n. 7.454/85); e (iii) acesso à propaganda partidária e eleitoral. Ante esse quadro, diversos partidos pequenos conseguiram algum sucesso nas eleições de 1985 e 1986, fazendo o sistema partidário brasileiro inflar ${ }^{37}$.

Os pequenos partidos, então um pouco mais fortes, continham algumas possibilidades interessantes para parlamentares que tinham a intenção de se fortalecerem politicamente. Ao filiar-se a um partido pequeno, o congressista, por exemplo, poderia assumir a direção da legenda em seu respectivo estado ou município, ganhando assim tempo de propaganda eleitoral para sua campanha ou até barganhando este tempo para coligações em eleições majoritárias na negociação com partidos maiores ${ }^{38}$.

Ranulfo Melo cita também a centralização dos poderes interna corporis no Congresso Nacional nas mãos da Mesa Diretora e também dos líderes partidários como outro fator que incentiva a migração partidária. Conforme será analisado a seguir, ao ser estudada a disciplina partidária, tal centralização trouxe forte disciplina dentro dos partidos, o que acarretou a alguns congressistas a rebelarem-se contra as decisões de seus respectivos líderes trocando de partido ${ }^{39}$.

\footnotetext{
${ }^{37}$ Cf. Carlos Ranulfo Melo. "Migração partidária na Câmara dos Deputados: causas, conseqüências e possíveis soluções", p. 326-327.

${ }^{38}$ Cf. Carlos Ranulfo Melo. "Migração partidária na Câmara dos Deputados: causas, conseqüências e possíveis soluções”, p. 328.

${ }^{39}$ Cf. Carlos Ranulfo Melo. "Migração partidária na Câmara dos Deputados: causas, conseqüências e possíveis soluções”, p. 329.
} 
O autor continua seu apontamento, ao indicar outra causa para as trocas de partido: a incerteza quanto ao futuro da carreira política do parlamentar. Ao analisar que a mudança de partido tem um custo baixo perante a sociedade e a legislação ser altamente permissiva, muitas vezes o congressista muda de partido para tentar crescer com mais rapidez suas chances de sucesso político-eleitorais. Ranulfo Melo detecta que há dois períodos em que se nota um número maior de mudanças de partido: janeiro/fevereiro e setembro/início de outubro, ambos os períodos principalmente no primeiro e terceiro anos de mandato. O primeiro período se deve, segundo o autor, ao fato de o parlamentar querer se posicionar diante do resultado eleitoral ocorrido no ano anterior (no primeiro ano, ele "se adapta" à eleição para presidente, governador, legislativo federal e estadual e no terceiro ano há a "adequação" ao resultado das eleições municipais). Já o período de setembro/início de outubro se deve ao fato de que este é o prazo final de filiação para poder concorrer na eleição do ano seguinte por outro partido $^{40}$.

Compreendidos os motivos para este fenômeno do quadro político-eleitoral brasileiro, passa-se à análise da legislação vigente atualmente e da grande mudança legal ocorrida em 2007.

A Constituição de 1988, ao contrário da Carta outorgada em 1969 pelo regime militar, não prevê textualmente qualquer punição aos políticos que troquem de partido durante o exercício do mandato ${ }^{41}$. $\mathrm{O}$ art. $17, \S 1^{\circ}$ da Constituição da República dispõe que cabe aos próprios partidos políticos estabelecem em seus estatutos normas a respeito da fidelidade e da disciplina partidária.

A ausência de punição constitucional textual à infidelidade partidária é criticada por Augusto Aras, autor que defende a releitura do artigo acima citado, "sob pena de

\footnotetext{
${ }^{40}$ Cf. Carlos Ranulfo Melo. "Migração partidária na Câmara dos Deputados: causas, conseqüências e possíveis soluções", p. 330-331.

${ }^{41}$ A única punição prevista pelo ordenamento jurídico brasileiro era, até a edição da Resolução TSE $n$. 22.610, de 25/10/2007, a perda da função ou cargo exercido na Casa Legislativa em virtude do princípio da proporcionalidade partidária, nos termos do art. 26 da LPP. Assim sendo, se o legislador saísse de seu partido, perdia o direito de participar das comissões legislativas, eis que as vagas atendem à proporção de cadeiras em cada Casa Legislativa.
} 
contínuo enfraquecimento do Estado Democrático brasileiro ou, na melhor das hipóteses, em manter o status quo com todas as mazelas da nossa classe política"42.

No entanto, o então Partido da Frente Liberal (PFL, atual DEM - Democratas) ingressou no TSE com a Consulta n. $1.398^{43}$, fato este que obrigou o Tribunal a decidir a respeito de tema espinhoso do sistema político brasileiro: apesar de a Constituição de 1988 não prever punição aos políticos infiéis textualmente, o mandato pertence ou não ao partido em caso de mandatários eleitos pelo sistema proporcional? Pouco tempo depois, o deputado federal Nilson Mourão (PT-AC) também ingressou com a Consulta n. $1.407^{44}$, sobre a manutenção do mandato pelo ocupante de cargo majoritário no caso de mudança de partido.

A primeira consulta, resumidamente, refere-se ao fato de que o indivíduo eleito por meio da eleição proporcional depende do partido para alcançar tal feito, eis que: (i) o art. 108 do CE dispõe que a eleição de candidato a cargo proporcional é resultado do quociente eleitoral apurado entre os partidos e as coligações; e(ii) a filiação partidária é condição constitucional de elegibilidade, condição esta que dá ao eleitorado noção do vínculo entre o postulante e seu partido, sua ideologia.

Já a Consulta apresentada pelo deputado petista simplesmente provoca o Tribunal para a possibilidade de manutenção do mandato pelo partido no caso de um filiado seu mudar para outra legenda mesmo exercendo mandato político executivo.

$\mathrm{Na}$ primeira Consulta, que trata da manutenção do mandato pelo partido em cargos proporcionais, os Ministros concordaram com os argumentos apresentados pelo PFL, usando-os para justificar o fato de que, apesar de não haver previsão constitucional, em especial nos arts. 54 e 55 da Constituição, o mandato em cargo proporcional pertence ao partido político e não ao legislador, devendo esse ter seu mandato cassado caso saia de seu partido sem justificativa.

\footnotetext{
${ }^{42}$ Augusto Aras. Fidelidade partidária: a perda do mandato parlamentar. Rio de Janeiro: Lumen Juris, 2006, p. 304.

${ }^{43}$ Consulta n. 1.398, j. 27.3.2007, DJ 8.5.2007, Rel. Min. Asfor Rocha.

${ }^{44}$ Consulta n. 1.407, j. 16.10.2007, DJ 28.12.2007, Rel. Min. Carlos Ayres Britto.
} 
Em seu voto em sede da Consulta n. 1.407, o Ministro Carlos Ayres Britto ressalta a importância do partido político na democracia representativa brasileira, eis que ele tem a primazia de não só ter a exclusividade de apresentar candidaturas, mas também legitimidade para impetrar mandado de segurança coletivo (art. $5^{\circ}$, inciso LXX, alínea "a" da Constituição da República), além de apresentar ação direta de inconstitucionalidade e ação declaratória de constitucionalidade (art. 103, inciso VIII).

O Ministro Ayres Britto prossegue em sua argumentação, ao dizer que o partido é quem coordena também a questão eleitoral tanto no sistema proporcional como no majoritário, já que escolhe seus candidatos em convenção partidária, procede ao registro dos mesmos na Justiça Eleitoral, coordena o horário eleitoral gratuito e financia as campanhas por meio do Fundo Partidário, além do fato de todos os candidatos terem sua identificação eleitoral vinculada ao seu partido, por meio da numeração necessária para ser votado na urna eletrônica.

Também é destacado o "aval ético-ideológico-profissional" do partido ao candidato, segundo reflexão do Ministro exposta a seguir:

(...) pois se candidatar por um partido ou coligação é deles receber uma espécie de atestado de bons antecedentes, pureza de propósitos, apego a regras de disciplina e lealdade associativa, sólido compromisso com idéias (o perfil ideológico de cada candidato se conhece é pelo perfil ideológico do seu partido) (...) Tão impensável é esse abandono por eles, candidatos já eleitos, quanto pelos partidos mesmos; que não podem desertar nem do seu ideário nem da cobrança de fidelidade por parte daqueles a quem ajudaram eleger. Afinal, avalista é assim mesmo: tem que velar pelo adimplemento dos compromissos assumidos pela pessoa a quem somente avalizou por lhe parecer digna de confiança ${ }^{45}$.

Nas duas Consultas, a votação do TSE foi unânime no sentido de que em qualquer dos dois sistemas (proporcional e majoritário), o mandato pertence ao partido e não ao candidato eleito, devendo este perdê-lo caso não justifique sua mudança.

Como não havia qualquer tipo de norma para a questão apresentada, o TSE editou a Resolução n. 22.610, de 25 de outubro de 2007, prevendo o processo legal

\footnotetext{
${ }^{45}$ Consulta n. 1.407, j. 16/10/07, Rel. Min. Ayres Britto.
} 
(entre eles, a legitimidade para apresentar a ação, a competência para o julgamento, os prazos processuais, entre outros aspectos) e as hipóteses de justa causa para a mudança de partido sem haver a perda do mandato por parte do trânsfuga, quais sejam: (i) incorporação ou fusão do partido; (ii) criação de um novo partido político; (iii) mudança substancial ou desvio reiterado do programa partidário e (iv) grave discriminação pessoal.

No momento em que referida Resolução foi editada, imaginou-se que as trocas partidárias estariam praticamente eliminadas do sistema político brasileiro. Porém, pode-se ver que ainda existem muitos casos de mudanças de partido no Congresso Nacional. Segundo a Agência Câmara, até 03 de outubro de 2009(prazo final para a filiação em partido político para poder candidatar-se nas eleições de 03 de outubro de 2010), 26 deputados federais mudaram de partido ${ }^{46}$. No Senado, houve a mudança de partido mais significativa desde a edição da referida Resolução: a senadora Marina Silva (PT-AC) saiu do PT e filiou-se ao PV almejando ser candidata à Presidência da República pelos verdes.

Além do fato de a Resolução ter tanto efeito no sistema político brasileiro ante as mudanças de partidos relatadas acima, há juristas que sustentam sua inconstitucionalidade, apesar de reiteradas decisões do STF no sentido da constitucionalidade da norma editada pelo TSE. Thales Tácito Pontes Luz de Pádua Cerqueira e Camila Medeiros de Albuquerque Pontes Luz de Pádua Cerqueira sopesam que, além de não haver nenhum dispositivo constitucional que trate da perda do mandato em caso de mudança de partido, se o candidato eleito mudar para um partido que pertence à coligação pela qual foi eleito, não deve haver punição ao trânsfuga.

Os autores argumentam que o art. $6^{\circ}, \S 1^{\circ}$ da LE determina que, no caso de coligação, os partidos funcionarão com se fossem apenas uma legenda. Ademais, o cálculo do quociente eleitoral é feito com base na votação da coligação, e não de cada partido participante. Assim, segundo os autores, os votos pertencem à coligação, e não ao partido, sendo eleitos os mais votados da coligação, respeitando-se inclusive a ordem de suplência da aliança. Portanto, para os autores, se o mandatário sair de seu partido

46 Disponível em: <http://www2.camara.gov.br/agencia/noticias/141057-Prazo-para-troca-de-partidotermina;-26-deputados-pedem-mudancas.html>. Último acesso em 15.11.2009. 
original e migrar para um partido que participava da coligação em sua eleição, não deve sofrer a punição prevista na Resolução TSE n. $22.610^{47}$.

Tratada a infidelidade partidária no sistema político brasileiro, será analisada a indisciplina partidária, apontada como outro fenômeno político brasileiro capaz de enfraquecer o sistema partidário brasileiro.

Enquanto a infidelidade caracteriza-se pela migração do político de um partido para outro (ou até a saída dele para permanecer no mandato, porém sem partido), a indisciplina não implica, inicialmente, a saída do político de seu partido, mas o fato de ele adotar linhas de atuação política, principalmente na esfera parlamentar, que divirjam do programa ou da ideologia de seu partido. Essa divergência pode também ocorrer no caso de "desobedecer" seu líder partidário em uma votação importante no Legislativo, por exemplo.

Difundiu-se o conceito entre os políticos, os acadêmicos e a sociedade de que uma das principais características do poder Legislativo, em especial do Congresso Nacional, é o fato de os legisladores serem "rebeldes incontroláveis", pois a cada votação de um projeto de lei - principalmente algum de maior interesse do poder Executivo - o parlamentar não respeitaria os ditames do seu partido e de seus respectivos líderes, negociando diretamente com os burocratas do governo favores ou concessões em troca de seus votos. Este diagnóstico é agravado pelo fato de os partidos políticos serem débeis, sem poder para exigir a disciplina de seus membros, já que se insatisfeitos, o político poderá trocar de legenda quando bem entender.

Scott Mainwaring classifica os partidos brasileiros em três tipos: (i) partidos disciplinados e programáticos; (ii) partidos moderadamente disciplinados e programáticos; (iii) partidos frouxamente disciplinados e programáticos. Para Mainwaring, há uma forte identificação entre ideologia e o tipo de partido. Os partidos de esquerda (PT, PPS, PC do B) seriam os mais disciplinados, com uma atuação congressual coesa e fortes laços com movimentos sociais e sindicatos. O segundo

\footnotetext{
${ }^{47}$ Cf. Thales Tácito Pontes Luz de Pádua Cerqueira / Camila Medeiros de Albuquerque Pontes Luz de Pádua Cerqueira. Fidelidade partidária e perda de mandato no Brasil: temas complexos. São Paulo: Premier Máxima, 2008, p. 272.
} 
grupo, de acordo com o autor, é composto por PDT, PSB, PSDB e possivelmente o PL (atual PR), já que não são tão coesos como os do primeiro grupo, mas também não são maleáveis e heterogêneos como todas as outras legendas ${ }^{48}$.

O autor, ao estudar a Assembléia Nacional Constituinte (1987-1988) concluiu que os partidos do terceiro grupo são altamente indisciplinados, pois "os representantes individuais votam da maneira que quiserem" ${ }^{\text {"49 }}$. Mainwaring argumenta que ao contrário do exemplo do PT, em que há uma associação de forte organização interna com mecanismos democráticos para se decidir os rumos da legenda, os partidos frouxamente disciplinados são avessos a tais medidas. Além disso, aceitam como filiados (e futuros candidatos) pessoas sem qualquer demanda ideológica ou organizacional. Os estatutos partidários contêm previsões sobre questões ideológicas e/ou disciplinares, mas eles não têm qualquer peso. $\mathrm{O}$ grande número de partidos existentes sugere aos políticos que em caso de desavença em seu partido, há muitas outras legendas que se adequam à sua necessidade ${ }^{50}$.

Por fim, o autor aponta como causas para a indisciplina partidária na maioria dos partidos brasileiros outros tópicos anteriormente estudados, como as candidaturas individuais e os fracos laços entre a legenda e a sociedade ${ }^{51}$.

Este é o cenário mais difundido no que diz respeito à atuação dos partidos e dos parlamentares na esfera legislativa. Argelina Figueiredo e Fernando Limongi, porém, consideram que esse quadro muito difundido na sociedade, caracterizado pela ingovernabilidade do país diante da indisciplina existente no Congresso é falso.

Em sua análise, Figueiredo e Limongi constataram que é bastante previsível a atuação do Congresso perante as propostas de interesse do Executivo. Os autores verificaram que há no Congresso Nacional uma verdadeira disciplina partidária: são poucos os casos em que alguns congressistas votam contra a indicação do líder de seu partido, e mais raro ainda as votações contra sua suposta ideologia.

\footnotetext{
${ }^{48}$ Cf. Scott Mainwaring. "Brazil: weak parties, feckless democracy", in Scott Mainwaring e Timothy R. Scully (ed.), Building democratic institutions: party systems in Latin America. Stanford, Stanford University Press, 1995, p. 376.

${ }^{49}$ Scott Mainwaring. "Brazil: weak parties, feckless democracy", p. 379.

${ }^{50}$ Cf. Scott Mainwaring. "Brazil: weak parties, feckless democracy", p. 380-381.

${ }^{51}$ Scott Mainwaring. "Brazil: weak parties, feckless democracy", p. 382-384.
} 
Assim sendo, a "explosiva combinação entre presidencialismo e um sistema pluripartidário baixamente institucionalizado (...) com fortes tendências à inoperância, (...) em que o presidente impotente e fraco se contraporia a um Legislativo povoado por uma miríade de partidos carentes de disciplina"52 ${ }^{\natural i m p l e s m e n t e ~ n a ̃ o ~ e x i s t e . ~}$

Essa nova interpretação do sistema partidário brasileiro se deve, segundo os autores, ao fato de o trabalho legislativo ser centralizado e ancorado na ação dos $\operatorname{partidos}^{53}$. Além do poder de agenda que o Executivo tem no Legislativo, ou seja, a capacidade de o Executivo determinar quais serão as propostas analisadas pelo Congresso e também qual é o melhor momento para essa análise, percebe-se também que os líderes partidários concentram muita força política no Congresso, já que por exemplo procedem à indicação de membros dos partidos a todas as comissões da respectiva $\mathrm{Casa}^{54}$.

O Colégio de Líderes ${ }^{55}$, formado por todos os líderes partidários e dos blocos parlamentares, também detém grandes poderes no processo legislativo, entre eles: (i) propor convocações extraordinárias (art. 66, § $4^{\circ}$ do RICD); (ii) requerer a prorrogação da duração de uma sessão (art. 72 do RICD) e (iii) apreciação de propostas em caráter preferencial (art. 160 do RICD).

Os autores reconhecem que o sistema eleitoral proporciona estratégias de campanhas individuais, com autonomia em relação aos partidos. No entanto, detectam que no Congresso a atuação de um parlamentar com independência frente aos ditames dos líderes partidários dificilmente prospera:

(...) a legislação partidária pode alimentar estratégias individualistas e antipartidárias. Essas estratégias, no entanto, não encontram solo fértil para desenvolver-se no Congresso Nacional. Projetos e emendas ditados exclusivamente por interesses eleitorais, particularistas e imediatistas raramente saem das gavetas

\footnotetext{
${ }^{52}$ Argelina Figueiredo e Fernando Limongi. Executivo e legislativo na nova ordem constitucional. 2 ed. Rio de Janeiro: Editora FGV, 2001, p. 19.

${ }^{53}$ Argelina Figueiredo e Fernando Limongi. Executivo e legislativo na nova ordem constitucional, p. 22.

${ }^{54}$ Arts. 66, 80 e 81 do Regimento Interno do Senado Federal; Art. 10, inciso VI do Regimento Interno da Câmara dos Deputados e Arts. $5^{\circ}$ e $9^{\circ}$ do Regimento Comum do Congresso Nacional

${ }^{55}$ Previsto no art. 20 do Regimento Interno da Câmara dos Deputados.
} 
das comissões. Emendas com esse fim são derrubadas em votações simbólicas onde o que conta são os líderes. ${ }^{56}$

Por fim, Figueiredo e Limongi destacam que na arena legislativa, os partidos políticos, ao contrário do defendido por Mainwaring, não são frágeis, diante do fato de que pelo partido a qual o congressista é filiado é bastante provável saber qual será seu voto em cada votação legislativa, além de também ser bastante provável definir sua orientação ideológica:

Os partidos políticos na Câmara não são peças de ficção. A filiação partidária nos diz muito a respeito do voto provável do parlamentar. As votações costumam dividir o plenário de acordo com padrões ideológicos clássicos: há uma direita, há um centro e uma esquerda. Além disso, há uma centro-direita e uma centroesquerda. Dito de outra maneira: o que tempos é uma alta fragmentação nominal a esconder uma baixa fragmentação real ${ }^{57}$.

Examinado o fenômeno da infidelidade e da indisciplina partidária, será debatido outro aspecto apontado como problemático no sistema partidário brasileiro: o número exagerado de partidos existente no país e a falta de um mecanismo legal para dirimir esse problema.

\subsubsection{Proliferação de partidos e a cláusula de desempenho}

Atualmente, há vinte e sete partidos políticos registrados no TSE, ou seja, siglas que têm direito a participar de todas as eleições realizadas no território nacional, acompanhadas de todas as suas prerrogativas: horário partidário gratuito, horário eleitoral gratuito e acesso aos recursos do Fundo Partidário.

O inchaço é apontado como um problema do sistema partidário brasileiro por muitos estudiosos, como Jairo Nicolau ${ }^{58}$, Scott Mainwaring ${ }^{59}$, Barbara Guedes e Artur

\footnotetext{
${ }^{56}$ Argelina Figueiredo e Fernando Limongi. Executivo e legislativo na nova ordem constitucional, p. 31.

${ }^{57}$ Argelina Figueiredo e Fernando Limongi. Executivo e legislativo na nova ordem constitucional, p. 93.

58 Cf. Jairo Nicolau, "Notas sobre as eleições de 2002 e o sistema partidário brasileiro", Cadernos Adenauer, ano IV, n.1, 2003, p. 11.

${ }^{59}$ Cf. Scott P. Mainwaring, Sistemas partidários em novas democracias: o caso do Brasil. (tradução de Vera Pereira). Porto Alegre: Mercado Aberto; Rio de Janeiro: Editora FGV, 2001, p.171.
} 
Ribeiro Neto ${ }^{60}$ e Maria D' Alva Gil Kinzo ${ }^{61}$, vivendo o Brasil um sistema pluripartidário exacerbado.

Tal exacerbação iniciou-se após o fim, em 1979, do regime bipartidário, forçado pela Ditadura Militar, no qual o quadro normativo permitiu o surgimento de um grande número de partidos ${ }^{62}$, visto que alguns grupos políticos não tinham preocupação com o número de legendas, porque pensavam que o pluripartidarismo era um "pré-requisito para a conquista de uma democracia efetiva ${ }^{63}$ ". David Fleischer ressalta que no período final do governo militar, o Brasil tinha um pluripartidarismo moderado e com o início dos governos civis, em 1985, deu-se a exacerbação, graças a uma mudança na legislação que facilitou sobremaneira a criação e o registro de novos partidos ${ }^{64}$.

A controvérsia, no entanto, reside no fato de esse número trazer ou não conseqüências danosas ao sistema político-eleitoral brasileiro.

Scott Mainwaring, por exemplo, defende que o sistema partidário brasileiro é pouco institucionalizado, já que: (i) os partidos não têm raízes profundas na sociedade; (ii) não há identificação entre eleitores e partidos; (iii) os partidos não têm legitimidade pública, ou seja, as agremiações não gozam de credibilidade perante o público. A baixa institucionalização, segundo o autor, acarreta na dificuldade de o eleitor cobrar seus representantes por sua atuação no Legislativo e também no Executivo. Ademais, há um alto índice de individualismo entre os políticos, fenômeno este que advém da adoção do sistema proporcional de lista aberta (conforme item 2.1.1) e também da fragilidade institucional dos partidos no Brasil ${ }^{65}$.

\footnotetext{
${ }^{60}$ Cf. Barbara Guedes e Artur Ribeiro Neto, "Fontes institucionais da corrupção no Brasil", in Keith S. Rosenn e Richard Downes (orgs.), Corrupção e reforma política no Brasil: o impacto do impeachment de Collor, (trad. Roberto Grey), Rio de Janeiro: Editora FGV, 2000, p. 64.

${ }^{61}$ Cf. Maria D’Alva Gil Kinzo, Radiografia do quadro partidário brasileiro, Rio de Janeiro: Fundação Konrad Adenauer, 1993, p. 1.

${ }^{62}$ Cf. Eduardo Martins de Lima. Sistemas multipartidários e eleitorais brasileiros em perspectiva comparada (1945-1964 e 1985-1998). São Paulo: Annablume; Belo Horizonte:FUMEC, 2004, p. 137.

${ }^{63}$ Rodrigo Patto Sá Motta, Introdução à história dos partidos políticos brasileiros. Belo Horizonte: Editora UFMG, 1999, p. 130.

${ }^{64}$ Cf. David Fleischer. Os partidos políticos. In: Lúcia Avelar \& Antônio Octávio Cintra. Sistema político brasileiro: uma introdução. Rio de Janeiro: Konrad-Adenauer-Stiftung; São Paulo: Editora Unesp, 2. ed., 2007, p. 308.

${ }^{65}$ Cf. Scott P. Mainwaring, Sistemas partidários em novas democracias: o caso do Brasil, p. 127-128.
} 
A instituição do segundo turno nas eleições para o poder Executivo também é uma fonte legislativa para o pluripartidarismo exacerbado. Nas eleições nas quais basta ao vencedor conseguir maioria simples, poucos partidos têm chances reais de vitórias, fazendo com que os partidos menores façam coligações pré-eleitorais com as legendas maiores. Com o passar do tempo, há uma tendência de extinção desses partidos menores, mesmo em países onde há sistema proporcional para as eleições legislativas. Havendo a possibilidade de segundo turno, porém, os partidos menores têm maiores estímulos para participar da eleição ao Executivo. Mesmo que não consigam ir ao segundo turno, poderão nele barganhar seu apoio a um dos dois candidatos por uma recompensa maior, como participação de destaque no eventual governo ${ }^{66}$.

O regime presidencialista, vigente no país desde a proclamação da República, em 1889 (com exceção ao período parlamentarista de 1961-1963) é também outro agente causador da fragilidade dos partidos políticos brasileiros, segundo Kinzo. Ante o quadro vigente de fragmentação partidária, é bastante provável que a maioria do eleitorado que elegeu o presidente da República, por exemplo, não reproduza seu voto nas eleições legislativas e construa uma maioria folgada para o governo, ao contrário do que ocorre no parlamentarismo, sistema em que só há formação de governo se o partido vencedor nas urnas conseguir formar maioria parlamentar. ${ }^{67}$.

O acesso ao horário partidário e eleitoral gratuitos é também apontado como elemento deturpador do sistema partidário. $\mathrm{O}$ candidato com algum capital político e/ou financeiro já acumulado tem uma escolha a fazer antes do período eleitoral. Pode filiarse e concorrer por um partido grande, com maior capilaridade e também outras lideranças fortes, dividindo por consequiência espaço na propaganda eleitoral de rádio e televisão ou ser membro de uma legenda pequena, tonar-se líder deste partido e conseguir maior tempo de exposição no horário eleitoral gratuito, quase o monopolizando ${ }^{68}$.

\footnotetext{
${ }^{66}$ Cf. Barbara Guedes e Artur Ribeiro Neto, "Fontes institucionais da corrupção no Brasil", p. 65.

${ }^{67}$ Cf. Maria D'Alva Gil Kinzo, Radiografia do quadro partidário brasileiro, p. 88.

${ }^{68}$ Cf. Barbara Guedes e Artur Ribeiro Neto, "Fontes institucionais da corrupção no Brasil”, p. 67.
} 
Mais uma vez, a possibilidade de os partidos formarem coligações eleitorais é apontada como uma mazela do sistema político brasileiro, não só nas eleições proporcionais (conforme item 2.1.1.1), mas também para o próprio sistema partidário.

As regras da eleição proporcional no Brasil, inicialmente, são prejudiciais à fragmentação partidárias, uma vez que se adota no país a fórmula D`Hondt de maiores médias. Nicolau esclarece que esta fórmula beneficia matematicamente os partidos mais votados, em prejuízo aos partidos menores. Além do que, ao se calcular o quociente eleitoral no momento da apuração dos votos, os partidos que não o atingiram estão excluídos da eleição, mesmo que a sobra dos partidos que atingiram o quociente seja menor que sua votação ${ }^{69}$. Assim sendo, a fórmula eleitoral brasileira usada nas eleições proporcionais não explica a alta fragmentação partidária, vez que seus dois aspectos beneficia as legendas maiores.

Outra característica do sistema proporcional brasileiro é a possibilidade de firmar coligações, segundo visto anteriormente. Para os partidos menores, a principal vantagem em participar de uma coligação na eleição proporcional é ter melhores condições para alcançar o quociente eleitoral e assim, poder eleger algum de seus candidatos. Concorrendo sozinhos, precisarão de grande soma de votos para alcançar o quociente, principalmente em circunscrições nas quais a magnitude seja baixa (no caso brasileiro, estados onde há um número baixo de representantes). Aline Machado demonstra que são os partidos menores quem mais participam de coligações; ademais, são nos estados em que a magnitude do distrito eleitoral é pequena (oito cadeiras) ${ }^{70}$ onde há maior ocorrência de coligações partidárias ${ }^{71}$.

Visto qual é a vantagem do partido menor ao coligar-se, indaga-se: o partido maior tem benefícios ao firmar aliança eleitoral com partidos menores? A resposta é positiva. O primeiro benefício é o acréscimo do tempo no horário eleitoral gratuito no rádio e na televisão (art. 47, $\S 2^{\circ}$, inciso II da LE). O segundo benefício constitui na

\footnotetext{
${ }^{69}$ Cf. Jairo Nicolau. Multipartidarismo e democracia: um estudo sobre o sistema partidário brasileiro (1985-1994), Rio de Janeiro, Editora FGV, 1996, p. 49-52.

${ }^{70}$ Acre, Amazonas, Amapá, Distrito Federal, Mato Grosso, Mato Grosso do Sul, Rio Grande do Norte, Rondônia, Roraima, Sergipe e Tocantins.

${ }^{71}$ Cf. Aline Machado, "A lógica das coligações no Brasil", in Silvana Krause e Rogério Schmitt, Partidos e coligações eleitorais no Brasil, Rio de Janeiro: Fundação Konrad Adenauer; São Paulo, Editora Unesp, 2005, p. 80.
} 
possibilidade de apresentar mais candidatos nas eleições proporcionais, pois enquanto o partido sozinho pode registrar candidatos até $150 \%$ do número de cadeiras a serem preenchidas (art. 10 caput da LE), a coligação pode registrar candidaturas em número equivalente ao dobro de cadeiras disponíveis (art. $10, \S 1^{\circ}$ da LE) ${ }^{72}$. Os partidos menores acabam também colaborando na sustentação dos candidatos majoritários dos partidos maiores, com recursos humanos e econômicos para a campanha ${ }^{73}$.

As coligações nas eleições proporcionais têm tamanha importância no sistema partidário que se elas fossem extintas, prevê-se enorme dificuldade aos partidos menores. Além disso, aponta Maria do Socorro Braga, muitos votos seriam desperdiçados, já que o número de corte na participação das legendas pequenas é o quociente eleitoral, fórmula esta que beneficia os partidos maiores, conforme acima estudado. A autora ressalta que em se extinguindo as coligações em eleições legislativas, recomenda-se a eliminação do quociente eleitoral, substituindo-se tal fórmula pelo advento somente da regra da maior média de $\mathrm{D}^{\prime} \mathrm{Hondt}^{74}$.

É difundido no cenário político brasileiro o fato de as coligações partidárias, ante as vantagens decorrentes de sua formação tanto para os partidos grandes como para os pequenos, não terem um tipo de filtro ideológico na sua formação. Ou seja, os partidos firmam a aliança eleitoral, de caráter provisório, não havendo qualquer exigência legal de sua manutenção na seara parlamentar nem numa eleição futura ${ }^{75}$, sem se preocuparem em se coligar com outras legendas do mesmo campo ideológico.

Essa visão estava tão alastrada que no início de 2002 o TSE editou Resolução que determinava a obrigação aos partidos de seguir nas eleições estaduais a mesma coligação firmada na esfera nacional. Era a vigência do princípio da coerência políticoeleitoral. Visava-se, portanto, que os partidos não fizessem em cada Estado coligações diferentes daquela firmada na eleição para a Presidência da República.

\footnotetext{
${ }^{72}$ Cf. Jairo Nicolau, Multipartidarismo e democracia: um estudo sobre o sistema partidário brasileiro (1985-1994), p. 76.

73 Cf. Rogério Schmitt. Coligações eleitorais e sistema partidário no Brasil. Tese de Doutorado apresentada ao Instituto Universitário de Pesquisas do Rio de Janeiro, 1999, p. 80.

${ }^{74}$ Cf. Maria do Socorro Braga. "Dinâmica de coordenação eleitoral em regime presidencialista e federativo: determinantes e conseqüências das coligações partidárias no Brasil”, in Gláucio Ary Dillon Soares e Lucio R. Rennó (orgs.), Reforma política: lições da história recente, Rio de Janeiro: Editora FGV, 2006, p. 234.

${ }^{75}$ Cf. Rogério Schmitt. Coligações eleitorais e sistema partidário no Brasil, p. 76-77.
} 
A verticalização e suas nuances podem ser mais bem explicadas com a leitura do trecho a seguir, no qual há inclusive um exemplo prático dos efeitos da obrigatoriedade de as alianças partidárias serem coerentes ideologicamente ante as alianças firmadas nas eleições de 2002:

Portanto, lembrando as coligações formadas em 2002, quando o PT aliou-se ao PL para eleger Luiz Inácio Lula da Silva, por exemplo, em nenhum estado da Federação os liberais ou os petistas poderiam aliar-se ao PSDB ou ao PMDB, que formaram outra aliança em torno do candidato José Serra. O PT poderia até ter um candidato ao governo estadual e o PL outro postulante, mas a verticalização impede qualquer aliança com agremiações que participem de outra aliança no âmbito nacional. Se o partido resolver não lançar candidato à Presidência e também não se coligar com outra agremiação, está livre para formar alianças com quiser, assim como fez o PFL em $2002^{76}$.

A verticalização das coligações partidárias vigorou nas eleições de 2002 e 2006, não tendo mais validade, pois foi promulgada a Emenda Constitucional n. 52/2006, que garante autonomia aos partidos políticos na formação de coligações para as eleições.

Apesar de a idéia de os partidos coligarem-se sem qualquer preocupação ideológica ser bastante disseminada, além de ter sido já objeto de Resolução do TSE, há análises que demonstram que as coligações, na maioria das vezes, têm pertinência ideológica. Ao dividir o campo ideológico em direita, esquerda e centro e submeter as coligações formadas a esta divisão, Aline Machado conclui que "as legendas tentam, sempre que possível, aliar-se dentro do próprio campo ideológico ${ }^{77}$ '. Mesma percepção teve Rogério Schmitt, que afirma que dois terços do total de coligações firmadas são ideologicamente consistentes. Se forem incluídas alianças um pouco menos consistentes, ver-se-á que quase nove em dez coligações ocorreram entre partidos de posições ideológicas idênticas ou contíguas ${ }^{78}$.

\footnotetext{
${ }^{76}$ Cf. Daniel Gustavo Falcão Pimentel dos Reis. Verticalização das coligações partidárias: melhor caminho para a coerência político-eleitoral?, Disponível em: <http://www.sbdp.org.br/artigos_ver.php?idConteudo=42>. Último acesso em 15.11.2009.

${ }^{77}$ Aline Machado, "A lógica das coligações no Brasil", p. 80.

${ }^{78}$ Cf. Rogério Schmitt. Coligações eleitorais e sistema partidário no Brasil, p. 105.
} 
Perante o diagnóstico apresentado, propõe-se uma série de alternativas para o sistema partidário brasileiro. Kinzo, por exemplo, defende a adoção de parâmetros referentes à fidelidade partidária, à cláusula de desempenho e um maior controle da Justiça Eleitoral sobre o financiamento da atividade política como mecanismos que fortalecerão as legendas ${ }^{79}$.

A cláusula de desempenho (ou cláusula de barreira) é o principal mecanismo apontado como solução para a alta fragmentação partidária brasileira. Ela consiste em um mecanismo legal ou constitucional que retira do partido com votação menor que o piso estipulado no ordenamento jurídico alguma prerrogativa de funcionamento.

Nelson Jobim, por exemplo, defende que ao não atingir o piso mínimo da cláusula, o partido deveria ter seu registro no TSE cancelado. A proposta, segundo o autor, tem a vantagem de deixar nas mãos do eleitorado a deliberação sobre o funcionamento ou não dos $\operatorname{partidos}^{80}$.

A maioria das propostas, porém, prevêem a perda do direito ao funcionamento parlamentar, que consiste no direito de o partido constituir bancada e liderança na respectiva Casa Legislativa, além de ser ver representado nos cargos e funções da respectiva $\mathrm{Casa}^{81}$. Ou seja, no caso de o partido não conseguir atingir o piso de votação, não terá seu registro cassado nem perderá as vagas no Legislativo, mas o partido não terá, por exemplo, direito de ter um líder dentro da $\mathrm{Casa}^{82}$ ou de qualquer parlamentar seu participar da Mesa ou de alguma comissão.

$\mathrm{O}$ art. 13 da LPP previa a vigência de uma cláusula de desempenho a partir das eleições de 2006. Só teria direito a funcionamento parlamentar em todas as Casas Legislativas brasileiras o partido que na eleição para a Câmara dos Deputados obtivesse no mínimo 5\% dos votos válidos na contagem nacional, devendo esses votos estarem

\footnotetext{
${ }^{79}$ Cf. Maria D'Alva Gil Kinzo, Radiografia do quadro partidário brasileiro, p. 91-93.

${ }^{80}$ Cf. Nelson Jobim, "Bases para uma reforma institucional", in João Paulo dos Reis Velloso (coord.), $O$ Brasil e as reformas políticas, Rio de Janeiro: José Olympio, 1992, p.9.

${ }^{81}$ Cf. Walter Costa Porto. O voto no Brasil: da Colônia à $6^{a}$ República, 2.ed. rev., Rio de Janeiro: Topbooks, 2002, p. 384.

${ }^{82}$ Os líderes têm prerrogativas especiais, como maior tempo para discursos e para recomendações aos demais colegas de partido no Plenário, além de participação no Colégio de Líderes.
} 
distribuídos em pelo menos um terço dos Estados, com no mínimo 2\% em cada um deles.

A cláusula de desempenho atingiu seus objetivos, já que muitas legendas não teriam direito ao funcionamento parlamentar. Logo após as eleições de 2006, houve grande movimentação no sistema partidário. O PAN foi incorporado pelo PTB; o PL fundiu-se ao PRONA, surgindo o Partido da República (PR); e houve a fusão entre PPS, PHS e PMN, que formaram a Mobilização Democrática (MD), diminuindo assim o número de partidos no cenário brasileiro.

Após esta movimentação, no entanto, o STF julgou em 07.12.2006 as ações diretas de inconstitucionalidade n. 1351-7 e n. 1354-8, ajuizadas logo após a publicação da LPP, em 1995. Ambas as ações foram relatadas pelo Ministro Marco Aurélio, e foram julgadas procedentes por unanimidade, sendo o art. 13 da LPP considerado inconstitucional, por ofender o direito de representação política das minorias. Após essa decisão, a fusão que formou a Mobilização Democrática foi desfeita. Já a fusão PLPRONA e a incorporação do PAN pelo PTB foram mantidas

Apesar de o sistema partidário brasileiro ser caracterizado pela infidelidade de seus filiados e pelo pluralismo exacerbado, crê-se que ele passa por um processo de maturação, ainda bastante recente. A infidelidade, por exemplo, ainda sobreviveu ao advento da Resolução do TSE que disciplina o tema. Tal Resolução, porém, foi um marco na legislação para tentar dirimir as fragilidades aqui apontadas no que diz respeito aos partidos. Ademais, houve significativa queda no número de trocas partidárias desde sua publicação.

Da mesma maneira, houve avanços quanto ao alto número de partidos. As coligações eleitorais, por exemplo, são normalmente baseadas no espectro ideológico, e não somente nas vantagens proporcionadas aos partidos pela legislação em vigor, em um claro sinal de que há um fortalecimento do sistema partidário brasileiro. Vêm do Congresso Nacional elementos claros de que a disciplina partidária não é uma miragem no cenário político brasileiro, fato este que contraria o panorama aterrorizador de que o país é ingovernável. Esse diagnóstico também é compartilhado por Leôncio Martins Rodrigues, que afirma que a análise do sistema partidário indica para o seu 
fortalecimento, tanto no aspecto ideológico como também no relacionamento com a sociedade e com os governos ${ }^{83}$.

\subsubsection{Campanhas eleitorais: propaganda no rádio e na televisão e o marketing político-eleitoral}

O sistema normativo referente às campanhas eleitorais é outro alvo dos críticos do sistema político-eleitoral brasileiro, além de ser tema de diversos projetos de lei no Congresso Nacional.

Entre seus mais diversos campos, as campanhas eleitorais têm um objetivo claro e nítido: maximizar as chances do candidato ser eleito, por meio de recursos de propaganda para que o eleitorado possa ser convencido de que o candidato é o melhor aspirante para uma vaga no Legislativo ou para o cargo em jogo no poder Executivo. E a propaganda política, durante uma campanha eleitoral, visa, segundo Afonso de Albuquerque, "incentivar a identificação do público com uma determinada versão acerca do significado da realidade - apresentada como verdadeira - em oposição às demais" $" 84$.

Para tanto, em sua maioria das vezes é necessária uma estrutura grande e cara, com posta de jornalistas, especialistas em marketing político-eleitoral (os famosos marqueteiros), advogados, além de uma equipe de bastidores para garantir a infraestrutura e os diversos compromissos que o candidato enfrenta durante a corrida eleitoral.

Assim, percebe-se que recursos financeiros são cada vez mais necessários para que as campanhas eleitorais possam ter alguma chance de sucesso na eleição. São necessárias atenção e altas despesas nos meios propagandísticos "tradicionais" das campanhas eleitorais, como distribuição de santinhos, organização de carreatas,

\footnotetext{
${ }^{83}$ Cf. Leôncio Martins Rodrigues, Partidos, ideologia e composição social: um estudo das bancadas partidárias na Câmara dos Deputados. São Paulo: Editora da Universidade de São Paulo, 2002, p. 48.

${ }^{84}$ Afonso de Albuquerque. A batalha pela Presidência: o Horário Gratuito de Propaganda Eleitoral na campanha de 1989. Tese de Doutorado apresentada na Escola de Comunicação da Universidade Federal do Rio de Janeiro, 1996, p. 262.
} 
comícios, visitas dos candidatos ao comércio local e às associações de bairro, confecção de adesivos e bandeiras, entre outros.

Ademais, normalmente é necessária a criação de um comitê eleitoral que serve como espécie de "quartel-general" da campanha, local no qual o candidato reúne-se com os principais chefes da campanha para articular as estratégias e os rumos que a candidatura deve seguir.

À propaganda tradicional e à infra-estrutura acima citada soma-se o fato de as campanhas serem bastante dependentes do horário eleitoral gratuito no rádio e na televisão, em que a campanha também fica mais dispendiosa, eis que há a necessidade de especialistas na área (produtora, roteiristas, estafe de retaguarda, designers, figurinistas, repórteres, entre outros).

Diante de tal montante de profissionais, surge a figura do marqueteiro, o especialista em marketing político-eleitoral, cultuado por muitos como um "mago das eleições". O marqueteiro é o regente da campanha, administrando todos os seus aspectos propagandísticos e ditando os rumos da postulação. Trata-se de serviço especializado e bastante caro, acarretando ainda mais gastos ao candidato. Sua presença, porém, é criticada por estudiosos, por muitas vezes desviar o foco da campanha eleitoral, fórum no qual deve haver debate de idéias e de propostas, e não devendo abrir espaço pra trucagens e maquetes construídas em computador para impressionar os eleitores.

Assim, neste item será analisada a importância da propaganda eleitoral no rádio e na televisão, para que se entenda melhor quais são suas reais chances de influência no curso da campanha eleitoral. Também será debatida a influência do marketing políticoeleitoral nas campanhas políticas, num estudo que terá como foco a real dimensão de seu valor como instrumento nas campanhas eleitorais.

A importância da propaganda eleitoral no rádio e na televisão nas campanhas eleitorais brasileiras é reconhecida pela maior parte dos estudiosos nos temas, de juristas a especialistas em comunicação, passando também pelos cientistas políticos observadores dos fenômenos eleitorais. 
Além de ser um meio bastante democrático, eis que todos os partidos têm acesso tanto ao horário eleitoral quanto ao partidário de forma gratuita, ele configura-se, na visão de Afonso de Albuquerque, em uma "possibilidade de utilizar os meios de comunicação de massa para apresentar sua própria versão da campanha e da realidade política" ${ }^{\natural 5}$.

Apesar de os meios tradicionais de propaganda ainda serem de suma importância, não há mais dúvida de que o horário eleitoral gratuito é o principal instrumento do candidato e do partido político para vencer a eleição. Alexandre Luis Mendonça Rollo corrobora com essa afirmação, conforme trecho a seguir:

Não se pode negar que, de todas as diferentes formas de propaganda eleitoral, aquela mais importante aos candidatos, até mesmo em razão de sua magnitude e capacidade de atingir um número maior de eleitores, é a realizada no rádio e na televisão. Por serem meios de comunicação de massa, o rádio e a televisão atingem, de uma só vez, milhares, às vezes até mesmo milhões de eleitores. ${ }^{86}$

A importância da propaganda no rádio e na televisão tornou-se notória no Brasil nas eleições presidenciais de 1989, em que Fernando Collor de Mello, jovem governador do pequeno Estado de Alagoas, filiado a um partido minúsculo, recémfundado e sem qualquer penetração no território nacional (PRN, hoje PTC) e pouco conhecido no cenário político nacional venceu as eleições, superando políticos tradicionais, filiados a partidos mais antigos e mais estruturados como o senador Mário Covas (PSDB), o ex-governador Leonel Brizola (PDT), o deputado federal paulista Ulysses Guimarães (PMDB), o ex-vice-presidente da República Aureliano Chaves (PFL, atual DEM), o ex-governador e hoje deputado federal Paulo Maluf (PDS, atual PP) e, no segundo turno, o deputado federal e hoje presidente da República Luiz Inácio Lula da Silva (PT).

Para Antonio Albino Canelas Rubim, a eleição presidencial de 1989 consolidou um novo modelo midiático para as eleições, além de chamar a atenção da sociedade

\footnotetext{
${ }^{85}$ Afonso de Albuquerque. A batalha pela Presidência: o Horário Gratuito de Propaganda Eleitoral na campanha de 1989, p. 267.

${ }^{86}$ Alexandre Luis Mendonça Rollo, "Propaganda eleitoral no rádio e na televisão", in Alberto Rollo (org.), Propaganda eleitoral: teoria e prática. São Paulo: Revista dos Tribunais, 2002, p. 85.
} 
para esse novo modelo ${ }^{87}$. Difundiu-se a partir de então a noção de que foi o horário eleitoral gratuito o principal instrumento para que Collor vencesse as eleições de 1989, mesmo diante de tantos políticos experimentados e de partidos com capilaridade muito maior no território nacional. Duda Mendonça, por exemplo, afirma que "Fernando Collor jamais teria sido presidente se não fosse a televisão" ${ }^{\text {" }}$.

$\mathrm{Na}$ visão de Rejane Vasconcelos Accioly Carvalho, a aparição de Collor no cenário eleitoral nacional e sua conseqüente vitória podem ser caracterizadas como a verdadeira ocorrência de um fenômeno eleitoral, "eis que houve um acontecimento excepcional, que escapa ao curso das expectativas e, portanto causa impacto surpreendendo pelas dimensões que assume" ${ }^{\text {} 89}$. Alerta a autora, porém, que a caracterização de um candidato como fenômeno eleitoral só vale para candidatos que, previamente não considerados competitivos, após curto período são taxados de favoritos a vencer a eleição ${ }^{90}$.

O panorama nacional em 1989 era desastroso: a economia passava por grandes dificuldades graças ao acelerado processo inflacionário e a altíssima rejeição ao presidente José Sarney (PMDB) fizeram com que os candidatos fizessem um discurso de oposição ao governo. Assim, os candidatos dos partidos de centro, mais identificados pela população com o governo Sarney, ficaram fora do segundo turno, já que desde o início do período eleitoral verificou-se uma polarização ideológica do debate eleitoral ${ }^{91}$.

Desde 1987, quando assumiu o governo do Estado de Alagoas, Fernando Collor foi projetado pela mídia como um “jovem político moderno, impetuoso e decidido, frontalmente contrário a Sarney" ${ }^{92}$. Ao lançar sua candidatura ao Planalto, atinge já bons níveis de intenção de voto nas pesquisas eleitorais. Sua candidatura foi fortalecida

\footnotetext{
${ }^{87}$ Cf. Antonio Albino Canelas Rubim. "Visibilidades e estratégias nas eleições proporcionais de 2002: política, mídia e cultura", in Antonio Albino Canelas Rubim (org.), Eleições presidenciais em 2002 no Brasil: ensaios sobre mídia, cultura e política. São Paulo, Hacker, 2004, p. 8.

${ }^{88}$ Duda Mendonça. Casos e coisas. 1. ed., 7. reimp., São Paulo: Globo, 2001, p. 47.

${ }^{89}$ Rejane Vasconcelos Accioly Carvalho. "Como se faz um 'fenômeno eleitoral': o caso Roseana", in: Antonio Albino Canelas Rubim (org.), Eleições presidenciais em 2002 no Brasil: ensaios sobre mídia, cultura e política. São Paulo, Hacker, 2004, p. 143.

${ }^{90}$ Cf. Rejane Vasconcelos Accioly Carvalho. "Como se faz um 'fenômeno eleitoral': o caso Roseana”, p. 143.

${ }^{91}$ Cf. André Singer. Esquerda e direito no eleitorado brasileiro: a identificação ideológica nas disputas presidenciais de 1989 e 1994. 1.ed., 1. reimp. São Paulo: Editora da Universidade de São Paulo, 2002, p. 51-52.

${ }^{92}$ Cf. André Singer. Esquerda e direito no eleitorado brasileiro, p. 56.
} 
pela propaganda partidária no primeiro semestre de 1989, eis que além do PRN, outros dois partidos (PSC e PST) usaram seus respectivos horários para difundir a imagem e as propostas de Collor.

No início da propaganda eleitoral no rádio e na televisão, em 15 de setembro de 1989, Collor tinha mais de $40 \%$ das intenções de voto nas pesquisas. Iniciado o horário eleitoral gratuito, Collor perde mais de $10 \%$ nas pesquisas, estabilizando-se na faixa de $28 \%$ a $30 \%$. Singer acredita que a queda se deu pelo crescimento de outras candidaturas de direita e do centro, como a de Covas, Maluf e Afif (PL), que ganharam adesão principalmente dos eleitores mais escolarizados. Porém, Collor permaneceu firme no primeiro lugar principalmente por dois fatores: o forte apoio nos bastidores do PFL, que praticamente abandonou a candidatura Aureliano Chaves e o forte apoio do eleitorado mais pobre e de menor escolaridade ${ }^{93}$.

Ao final do primeiro turno, realizado em 15 de novembro de 1989, Collor teve $30,4 \%$ dos votos válidos e Lula, 17,1\%, passando os dois primeiros colocados ao segundo turno. As primeiras pesquisas davam a Collor uma boa vantagem (por volta de $50 \%$ das intenções de votos, enquanto Lula tinha 38\%), trazendo a impressão de que a eleição já estava vencida, já que Lula teria que além de convencer os eleitores indecisos, trazer também eleitores com a intenção de votar em Collor para vencer a corrida ao Planalto. Com o apoio do PSDB e do PDT, Lula cresce nas pesquisas, chegando a ter $43 \%$ contra $47 \%$ de Collor. ${ }^{94}$

Contudo, poucos dias antes da eleição, em uma "operação para o estancamento da sangria de votos" 95 , Collor lançou em seu horário eleitoral uma propaganda em que uma ex-namorada de Lula o acusou de ter pedido a ela proceder a um aborto. Após, realizou-se o último debate televisionado, em que Collor saiu-se melhor. Por fim, na véspera da eleição, a Rede Globo de Televisão fez uma edição do debate para veiculá-lo em seu principal telejornal, o Jornal Nacional, edição esta em que a Rede foi acusada de privilegiar o Collor, fato atribuído como fundamental para a vitória do candidato do PRN em dezembro de 1989.

\footnotetext{
${ }^{93}$ Cf. André Singer. Esquerda e direito no eleitorado brasileiro, p. 58-59.

${ }^{94} \mathrm{Cf}$. André Singer. Esquerda e direito no eleitorado brasileiro, p. 62-65.

95 Chico Santa Rita. Batalhas eleitorais: 25 anos de marketing político. São Paulo: Geração Editorial, 2001, p. 95.
} 
A principal novidade na legislação eleitoral de 1989 para cá é a criação das inserções eleitorais, os chamados spots (art. 51 da LE), que é a possibilidade de o candidato ou o partido colocar entre às $8 \mathrm{~h}$ e às $24 \mathrm{~h}$ esquetes comerciais de $30 \mathrm{~s}$ ou 1 $\min ^{96}$. Rogério Schmitt, Karina Kuschnir e Leandro Piquet Carneiro afirmam que o advento das inserções é uma resposta às críticas principalmente com origem na mídia, que alegava que o horário contínuo gerava prejuízo ao faturamento das emissoras e também aos índices de audiência ${ }^{97}$.

Para Afonso de Albuquerque, o horário eleitoral contínuo (que continua a existir, porém menor que antigamente) era ruim, pois: “1) as afirmações feitas pelo programa de um candidato podem ser desmentidas logo em seguida, pelo programa de um outro; e 2) as mensagens não podem ser exaustivamente repetidas, tal como ocorre nos Estados Unidos $^{98 \%}$. Maurício Ribeiro de Barros destaca uma vantagem da inserção frente ao horário contínuo, que é não ter o caráter de "interrupção abrupta e duradoura da programação normal das emissoras à qual o eleitor/telespectador está acostumado ${ }^{99}$ ".

No entanto, as inserções trazem menos possibilidades aos candidatos, eis que nelas são vedadas a utilização de gravações externas, trucagens ou montagens, computação gráfica, desenhos animados e efeitos especiais, numa demonstração de que "o legislador prioriza as mensagens verbais das direções partidárias ${ }^{100 "}$.

Após 1989, os partidos, os candidatos e os profissionais da área priorizaram ainda mais a propaganda no rádio e na televisão, ante o impacto que ela pode trazer a uma eleição. Desde então, principalmente nas candidaturas majoritárias, ganhou espaço o trabalho do marqueteiro político.

\footnotetext{
${ }^{96}$ Há a permissão legislativa para as inserções desde a eleição de 1996.

${ }^{97}$ Cf. Rogério Schmitt, Karina Kuschnir e Leandro Piquet Carneiro, "Estratégias de campanha no horário gratuito de propaganda eleitoral em eleições proporcionais", Dados, v. 42., n. 2. 1999.

${ }_{98}$ Afonso de Albuquerque. A batalha pela Presidência: o Horário Gratuito de Propaganda Eleitoral na campanha de 1989, p. 111.

${ }^{99}$ Maurício Ribeiro de Barros. Efeitos de campanha: um estudo sobre a valorização do Horário Gratuito de Propaganda Eleitoral no pleito para a prefeitura de São Paulo em 1996. Dissertação de Mestrado apresentada ao Departamento de Ciência Política da Faculdade de Filosofia, Letras e Ciências Humanas da Universidade de São Paulo, 2001, p. 23.

${ }^{100}$ Joel J. Cândido. Direito eleitoral brasileiro. 13. ed., rev., atual. e ampl., Bauru: Edipro, 2008, p. 520.
} 
O uso de ensinamentos do marketing nas campanhas eleitorais é bastante criticado. Rubens Figueiredo, por exemplo, assevera que os marqueteiros são considerados como uns manipuladores, bruxos que usam de baixarias para reverter tendências eleitorais, pois apresentam seu candidato (cliente) ao eleitorado como algo que na verdade ele não é, constituindo-se como verdadeiros falsificadores da vontade do eleitorado. Destaca o autor também que a própria mídia tem seu papel na formação dessa impressão na sociedade, eis que os taxam de magos, deuses que operam mudanças rápidas no pensamento do eleitorado ${ }^{101}$.

Figueiredo aponta que o aumento do poder do marqueteiro nas campanhas gerou graves deformações, entre elas: (i) simbiose entre o marqueteiro e o candidato, com o programa de televisão de um candidato sendo objeto de divulgação maior até que o próprio postulante e suas propostas; (ii) a perda do componente político das campanhas, eis que há marqueteiros que usam das mesmas estratégias de campanha para candidatos de ideologias diametralmente diferentes, ou até de localidades bastante diversas; (iii) o marqueteiro deixa de ser coordenador da campanha na parte de propaganda e passa a ser o formulador de propostas de políticas públicas ${ }^{102}$.

Pode-se citar como exemplo para a última deformação citada por Figueiredo a eleição de Celso Pitta para a Prefeitura de São Paulo em 1996. Nesta eleição, verificouse que a principal demanda da sociedade paulistana era a melhoria do sistema de transportes urbanos. Diante de tal quadro, os três principais candidatos lançaram suas propostas: José Serra (PSDB) prometeu expandir o Metrô em acordo com o governo do Estado; Luiza Erundina (PT) anunciou a ampliação dos sistemas de corredores de ônibus, tal qual fizera quando prefeita e Celso Pitta (PPB, atual PP) propôs a criação de um sistema inédito de trens urbanos, o "Fura-Fila", sendo o eleitorado bombardeado com propagandas recheadas com efeitos gráficos e especiais mostrando como funcionaria o novo trem. Alega-se que o "Fura-Fila" não foi criação do candidato ou de um assessor de Pitta, mas sim de seu marqueteiro, Duda Mendonça.

${ }^{101}$ Cf. Rubens Figueiredo. "O marketing político: entre a ciência e a falta de razão", in: Rubens Figueiredo (org.), Marketing político e persuasão eleitoral, São Paulo: Fundação Konrad Adenauer, 2000, p. 11-12.

${ }^{102}$ Cf. Rubens Figueiredo. "O marketing político: entre a ciência e a falta de razão", p. 37-38. 
José Genoíno também argumenta que a utilização de técnicas de marketing agrava os problemas do sistema político brasileiro, pois essas técnicas esvaziam o conteúdo político da campanha e acentuam cada vez mais o caráter propagandístico e mercadológico. Assevera Genoino que a política está deixando de ser um foro de debate e convencimento para tornar-se um método de caráter impositivo e manipulador ${ }^{103}$.

Apesar de tal diagnóstico disseminado na sociedade e no cenário político brasileiro, não resta dúvida de que o marketing político-eleitoral é e será cada vez mais importante na política brasileira, sendo inclusive considerado por Jorge Almeida como “imprescindível (...) ante a atividade política ampla, no mundo contemporâneo e em sociedades com características semelhantes a nossa" ${ }^{104}$.

Venício A. de Lima, por exemplo, considera que no caso da eleição de 1989, o horário eleitoral gratuito não foi o item mais fundamental para a vitória de Fernando Collor, mas sim todo o trabalho de marketing político feito desde 1987, principalmente na mídia, conforme trecho a seguir:

A grande habilidade de Collor foi, mediante eficiente estratégia de marketing, identificar-se com a temática e as posições políticas construídas no e pelo CR-P [Cenário de Representação da Política]. Adaptando sua imagem pública ao "perfil ideal" de candidato, paulatinamente impôs-se ao "moderno" establishment (nacional e/ou associado) como o único capaz de encarnar e representar os seus interesses, articulando assim seu apoio e conquistando os votos não-ideológicos dos eleitores que lhe garantiram a vitória. ${ }^{105}$

Ante a importância do marketing para o sucesso de uma campanha, deve-se analisar o papel do marketing na campanha. O marketing político-eleitoral consiste em fazer um planejamento prévio antes do período eleitoral (o marketing político) e em administrar a infra-estrutura, os recursos e as pessoas participantes durante a campanha (o marketing eleitoral).

\footnotetext{
${ }^{103}$ Cf. José Genoíno Neto, "A crise brasileira e a reforma da política”, in João Paulo dos Reis Velloso (coord.), O Brasil e as reformas políticas, Rio de Janeiro: José Olympio, 1992, p. 133.

104 Jorge Almeida. Marketing político: hegemonia e contra-hegemonia. São Paulo: Xamã; Editora Fundação Perseu Abramo, 2002, p. 229.

${ }^{105}$ Venício A. de Lima. Mídia: teoria e política. São Paulo: Editora Fundação Perseu Abramo, 2001, p. 219.
} 
O marketing político é espécie de administração da imagem e dos feitos do candidato no período pré-eleitoral. Independentemente de já deter cargo político, o postulante pode, por exemplo, construir um sítio na Internet, mandar ao eleitorado notícias com as realizações de seu mandato e com suas propostas (sempre com o cuidado de evitar realizar propaganda antecipada, ato vedado pela LE), costurar de antemão alianças com líderes populares (líderes comunitários, presidentes de associações de bairros). Deve o candidato preparar o terreno para nos três meses de eleição conseguir administrar e fazer crescer ainda esse capital político visando ao período eleitoral.

Já no início do período eleitoral (julho do ano de eleições), logo após as Convenções partidárias, o candidato deve constituir sua infra-estrutura de campanha e por em prática tudo o que foi planejado anteriormente, visando maximizar a propaganda agora eleitoral e amealhar votos.

Apesar de ser bastante diferente o tipo de trabalho - no marketing político, faz-se espécie de planejamento para o período eleitoral, além de criação e manutenção da imagem do candidato visando uma forte visibilidade no período eleitoral - e de os períodos serem bastante destacados - o marketing eleitoral ocorre entre julho e outubro do ano eleitoral e o marketing político em todas as outras épocas, eles são indissociáveis, segundo Jorge Almeida, pois fazem parte de um mesmo processo na busca da vitória eleitoral ${ }^{106}$.

O planejamento e a consecução de uma campanha eleitoral não é tarefa simples e barata. Ronald A. Kuntz afirma que são estes os cargos necessários para montar a infra-estrutura de uma campanha: (i) chefe da campanha, com a missão de coordenação de todos seus aspectos; (ii) coordenador financeiro, que cuida da administração dos recursos de campanha e detém os contatos com possíveis doadores e fornecedores; (iii) coordenador de ação política, ficando sob sua responsabilidade proceder às análises de alianças (verificar em cada região/reduto eleitoral quais são as chances do candidato e com quem ele deve aliar-se), bem como coordenar os setores de comunicação, de assessoria de imprensa; operacional-administrativo (materiais, serviços, transporte), de

\footnotetext{
${ }^{106}$ Cf. Jorge Almeida. Marketing político: hegemonia e contra-hegemonia. p. 230.
} 
pesquisas; fazer contatos com grupos de grandes eleitores (sindicatos, clubes, associações de bairro, grupos comunitários, organizações religiosas); (iv) coordenador de agenda, responsável por agendar compromissos de campanha, fazer roteiros de viagens, de carreatas; e (v) conselheiros políticos, que podem opinar sobre os rumos da campanha $^{107}$.

Além da estrutura acima arrolada, outro item fundamental para o sucesso de uma campanha eleitoral é a feitura de pesquisas. Para Rubens Figueiredo, uma campanha sem pesquisas é o mesmo que "um tiro no escuro, navegar sem bússola", eis que são elas que

(...) definem a postura do candidato, os temas da campanha, as propostas que serão apresentadas aos eleitores, a forma de apresentá-las, quais segmentos do eleitorado devem ser priorizados e de que maneira, quais apoios são importantes, se é conveniente atacar ou não os outros candidatos. ${ }^{108}$

Percebe-se no estudo da propaganda eleitoral no rádio e na televisão e da forte e necessária presença do marketing político-eleitoral que o fenômeno das campanhas eleitorais no Brasil é bastante complexo, havendo vantagens e desvantagens no modo hoje vigente no Brasil. No entanto, Afonso de Albuquerque defende veementemente a existência do horário eleitoral gratuito, pois além de ser um instrumento que proporciona acesso a todos os candidatos, ele tem o condão de atenuar a dependência da população em face do pequeno número de organizações noticiosas ${ }^{109}$.

Nota-se, igualmente, ante a análise feita que a estrutura de uma campanha não é pequena, havendo grande necessidade de dinheiro para mantê-la. Os mais diversos profissionais envolvidos, os gastos com propaganda e a infra-estrutura da candidatura são importantes para o sucesso da postulação, e envolvem um custo substancial. Assim, entra-se em outra grande fragilidade do sistema político-eleitoral brasileiro: o financiamento da atividade política no Brasil.

\footnotetext{
${ }^{107}$ Cf. Ronald A. Kuntz. Manual de campanha eleitoral: marketing político. 10. ed., São Paulo: Global, 2004, p. 38-48.

${ }^{108}$ Rubens Figueiredo. "O marketing político: entre a ciência e a falta de razão", p. 20.

${ }^{109}$ Cf. Afonso de Albuquerque. A batalha pela Presidência: o Horário Gratuito de Propaganda Eleitoral na campanha de 1989, p. 266.
} 


\subsubsection{Financiamento da política}

Neste item, serão estudados os principais diagnósticos existentes nas análises pertinentes ao panorama político-eleitoral brasileiro no que toca ao financiamento da atividade política.

Conforme visto no item 1.1, o financiamento da política é tema de suma relevância para o entendimento dos problemas apresentados pelo contexto político brasileiro, pois normalmente é a origem dos escândalos envolvendo irregularidades tanto no âmbito eleitoral como também na Administração Pública ${ }^{110}$.

Entre os políticos, sempre é ressaltado que as irregularidades existentes no campo do financiamento da atividade política no Brasil decorrem do próprio sistema, ou seja, é o próprio ordenamento jurídico que leva os políticos a cometerem as infrações previstas na legislação, sendo tais infrações consideradas corriqueiras ${ }^{111}$, ou consideradas até um aspecto cultural da política brasileira ${ }^{112}$. Monica Herman Caggiano corrobora com esse diagnóstico, conforme trecho adiante:

A engrenagem visualizada pelo legislador, porém, ainda não configura o sistema ideal, haja vista o elenco de casos de espúria canalização do dinheiro nesses períodos. Isso, em parte, em razão das vedações excessivas que pressionam em demasia partidos e candidatos, conduzidos as finanças político-partidárias eleitorais a transitar por uma via marginal, ilegal ${ }^{113}$.

Entre as críticas existentes, a principal delas está no próprio cerne do sistema vigente no Brasil. Apesar de o financiamento da atividade política (ou seja, dos partidos políticos e das campanhas eleitorais) poder ser classificado como misto (ou seja, há recursos tanto de origem privada como de origem pública), na prática o sistema

\footnotetext{
${ }^{110}$ Cf. João Heliofar de Jesus Villar, "Corrupção: o ovo da serpente", in Folha de S. Paulo, edição de 4.1.2010, p. A3.

${ }^{111}$ Cf. Jairo Nicolau, "Para reformar o financiamento de campanhas no Brasil", in Democracia Viva, n. 37 , dez./2007, p. 9.

${ }^{112}$ Cf. Fábio Wanderley Reis. "Dilemas da democracia no Brasil", in Lúcia Avelar e Antônio Octávio Cintra, Sistema político brasileiro: uma introdução, 2. ed. rev., e ampl., Rio de Janeiro: Konrad-Adenauer Stiftung; São Paulo: Editora Unesp, 2007, p. 486.

${ }^{113}$ Monica Herman Salem Caggiano, Direito parlamentar e direito eleitoral, Barueri: Manole, 2004, p. 143.
} 
brasileiro caracteriza-se como fortemente privado, portanto, dependente das doações de pessoas jurídicas e físicas permitidas por lei a realizarem as doações.

O financiamento público da política no Brasil, previsto no art. $17, \S 3^{\circ}$ da Constituição, caracteriza-se pelo repasse de verbas públicas previstas na lei orçamentária anual para o Fundo Partidário, conforme prevê a LPP, que conforme será analisado no item 3.2.2 deste trabalho, é na prática suficiente apenas para o pagamento das atividades permanentes dos partidos políticos em períodos não eleitorais. Além do fundo partidário, o horário partidário e eleitoral gratuito (foco do item 3.2.3 deste trabalho) é a outra forma do financiamento público da atividade política no Brasil.

Também se deve ressaltar que a Constituição prevê a imunidade tributária dos partidos políticos e de suas respectivas fundações sobre impostos sobre patrimônio, renda ou serviços (art. 150, inciso VI, alínea "c" da Constituição, fato este que garante também mais recursos aos partidos ${ }^{114}$.

Ante o fato de o Fundo Partidário garantir aos partidos recursos insuficientes para as campanhas eleitorais e o horário partidário e eleitoral gratuito ser fonte pública de caráter indireto ${ }^{115}$, as legendas e os candidatos devem procurar nas doações privadas de pessoas físicas e jurídicas o sustento de suas campanhas.

Esta necessidade premente das campanhas eleitorais de se viabilizarem por meio de recursos privados traz a possibilidade de os doadores fazerem o aporte de recursos nas campanhas para conseguir alguma vantagem em troca futuramente, se o candidato financiado conseguir eleger-se ${ }^{116117}$.

\footnotetext{
${ }^{114}$ Cf. Marcelo Passamani Machado, "O financiamento das campanhas eleitorais: perspectivas para uma reforma política", in Monica Herman Salem Caggiano (org.), O voto nas Américas, Barueri: Manole, 2008, p. 189.

${ }^{115}$ Os partidos e candidatos têm acesso ao horário, porém os recursos públicos que o sustentam não passam pelas legendas, tampouco pelos candidatos, já que o horário é pago pelo mecanismo tributário da compensação fiscal.

${ }^{116}$ Corrobora com esta afirmação Jairo Nicolau, que também ressalta que as doações podem ser também uma forma de agradecimento a um favor já feito pelo político no transcorrer do mandato (Cf. Jairo Nicolau, "Para reformar o financiamento de campanhas no Brasil", p. 9).

${ }^{117}$ A influência do poder econômico no período eleitoral e pós-eleitoral é enfatizada pelo fato de a grande maioria das doações se originarem de pessoas jurídicas, e não de pessoas físicas (Cf. David Samuels, "Financiamento de campanha e eleições no Brasil: o que podemos aprender com o 'caixa um' e propostas de reforma", p. 367.
} 
Esse mecanismo pode funcionar, por exemplo, da seguinte forma: uma empresa doa o recurso para a campanha de um candidato à Câmara dos Deputados que consegue ser eleito. Já congressista, poderá apresentar projeto de lei que beneficie a atividade dessa empresa ou garantir recursos no orçamento da União para programa ou obra de interesse da empresa financiadora ${ }^{118}$.

O mecanismo da "troca de favores" pode ter fortes efeitos no cenário político brasileiro, ao abrir espaço para práticas de caráter corrupto ou então pelo fato de haver grande representação nas Casas Legislativas brasileiras de grupos econômicos abastados, em detrimento de parcela da população que não tem força para fazer suas reivindicações tanto no transcorrer da legislatura como também no período eleitoral ${ }^{119}$.

Além disso, o poder econômico, mesmo que não com o objetivo de conseguir vantagens futuras, pode influenciar de modo decisivo na eleição, de modo a afetar inclusive a legitimidade e a normalidade do pleito. A legitimidade e a normalidade das eleições, ditames protegidos constitucionalmente (art. 14, § $9^{\circ}$ da Constituição) são afetadas pelo poder econômico se o uso desse poder vier a ser usado de modo abusivo, ou seja, de forma que haja um desequilíbrio nas chances dos postulantes de ser eleito. Carlos Velloso e Walber Agra criticam o fato de o sistema de financiamento vigente hoje no Brasil proporcionar desequilíbrio entre os competidores, conforme trecho adiante:

A predominância do sistema de financiamento privado fez com que os detentores do poder econômico tenham vantagem nas eleições, tornando o sistema eleitoral extremamente desigual, haja vista privilegiar os cidadãos que dispõem de fontes de financiamento em detrimentos daqueles que não possuem condições financeiras suficientes ${ }^{120}$.

\footnotetext{
118 Simone Rodrigues da Silva Bohn, David Fleischer e Francisco Whitacker também apontam como possibilidade de "troca de favores" as licitações públicas que poderão ser viciadas para privilegiar financiadores de campanha; a concessão de empréstimos subsidiados; a criação de incentivos fiscais, políticas de subsídios e a criação de políticas públicas que possam favorecer empresa doadora. (Cf. Simone Rodrigues da Silva Bohn, David Fleischer e Francisco Whitacker, "A fiscalização das eleições", in Bruno Wilhelm Speck (org.) Caminhos da transparência: análise de dois componentes de um sistema nacional de integridade, Campinas: Editora da Unicamp, 2002, p. 345).

${ }^{119}$ Cf. Marcelo Passamani Machado, "O financiamento das campanhas eleitorais: perspectivas para uma reforma política", p. 198.

${ }^{120}$ Carlos Mário da Silva Velloso e Walber de Moura Agra, Elementos de direito eleitoral, São Paulo: Saraiva, 2009, p. 223.
} 
A probabilidade de condutas que se caracterizem como abuso do poder econômico é bastante alta, já que as campanhas eleitorais brasileiras não têm grande necessidade do dinheiro de origem privada $^{121}$ somente porque há poucos recursos públicos para tanto, mas também em grande medida pelo alto preço das campanhas eleitorais $^{122}$.

A duração do período de campanha (por volta de três meses), somado ao modelo vigente no país fazem com que as campanhas sejam bastante dispendiosas. Primeiramente, como se detectou no item 2.1.3, as campanhas no geral (principalmente as majoritárias) são fortemente dependentes do horário eleitoral gratuito e de mecanismos do marketing político-eleitoral.

Quanto mais dinheiro a campanha arrecadar, mais dinheiro será dirigido para as propagandas no rádio e na televisão, acarretando substancial evolução em aspectos artísticos da campanha (melhor desenvolvimento de cenários, resolução de imagem, mais equipes de vídeo e de repórteres percorrendo as cidades para filmar cenas externas, melhores efeitos gráficos e eletrônicos, entre outros), deixando de lado o convencimento do eleitorado a partir da apresentação de propostas e do programa do partido $^{123}$.

Afonso de Albuquerque, porém, critica o argumento de que as propagandas eleitorais na televisão, ao se utilizarem de mecanismos típicos de sua linguagem - como montagens, trucagens ou cenas externas - ganhem maior poder de argumentação. Tal crítica tem como base a eleição de 1994, em que foram proibidos o uso de cenas externas, montagens, trucagens e a presença de outra pessoa quando o candidato estivesse em tela. Segundo Albuquerque, constitui-se uma situação paradoxal o fato de

\footnotetext{
${ }^{121}$ Fernando Muniz Santos considera essa dependência como o "cerne do problema" do financiamento de campanhas no Brasil, ao criticar o fato de a legislação eleitoral não trazer regras precisas para delimitar o financiamento privado de campanhas eleitorais (Cf. Fernando Muniz Santos, "Abuso de poder econômico eleitoral: por uma definição complessiva desse instituto", in Antenor Demeterco Neto (coord.), Os abusos nas eleições: a conquista ilícita de mandato eletivo, São Paulo: Quartier Latin, 2008, p. 35).

122 Também apontam como fator problemático do sistema eleitoral brasileiro o alto custo das campanhas Jairo Nicolau ("Para reformar o financiamento de campanhas no Brasil", in Democracia Viva, n. 37, dez./2007, p. 8) e David Samuels ("Financiamento de campanha e eleições no Brasil: o que podemos aprender com o 'caixa um' e propostas de reforma", p. 368).

${ }^{123}$ Cf. Paulo Adib Casseb, "Financiamento público de campanha", in Alberto Rollo (org.), Reforma política: uma visão prática, São Paulo: Iglu, 2007, p. 57, e Monica Herman Salem Caggiano, "Corrupção e financiamento das campanhas eleitorais", in Fernando Aurelio Zilveti e Silvia Lopes (orgs.), O regime democrático e a questão da corrupção política, São Paulo: Atlas, p. 132-134.
} 
se facultar aos partidos o uso da televisão, mas sob a condição de que eles não usem de linguagem televisiva, paradoxo este que deixou o horário eleitoral gratuito "menos atraente", não significando "um aumento do poder de argumentação dos programas"124.

Não restam dúvidas, porém, que a elevada importância da propaganda política no rádio e na televisão traz conseqüentemente um aumento dos gastos políticoeleitorais. Mas não necessariamente os efeitos desses gastos são tão perversos na influência da vontade do eleitor.

Depois, o sistema eleitoral de lista aberta vigente para as eleições proporcionais brasileiras acarreta o surgimento das candidaturas individuais (vide item 2.1.1.2 deste trabalho), que também fazem crescer o custo das campanhas eleitorais.

Nas eleições proporcionais brasileiras, conforme visto anteriormente, as candidaturas são de caráter individual, principalmente pelo fato de que o candidato, além de ter que lutar no período eleitoral para maximizar o número de votos em seu nome contra todos os adversários dos outros partidos, deve conseguir uma votação grande o suficiente para ficar bem colocado lista de candidatos de seu próprio partido. $\mathrm{Na}$ prática, seus adversários são tanto os candidatos dos outros partidos quanto os postulantes da sua legenda.

Ante esse fato, toda a infra-estrutura de campanha nas eleições proporcionais brasileiras é individual: cada candidato deve formar um comitê e um staff próprio, além da propaganda também ser feita por conta própria ${ }^{125126}$.

Alega-se também que a fragilidade dos partidos políticos é outro fator que acarreta o encarecimento das campanhas eleitorais. Apesar de as legendas brasileiras não serem tão frágeis como apontado por alguns estudiosos (vide item 2.1.2), principalmente no âmbito legislativo, o fato de serem entidades em processo de

\footnotetext{
${ }^{124}$ Afonso de Albuquerque, A batalha pela Presidência: o Horário Gratuito de Propaganda Eleitoral na campanha de 1989, p. 267.

${ }^{125}$ Há a exceção da propaganda no rádio e na televisão. Como o horário é do partido, cabe a ele dividir o tempo entre seus filiados candidatos, além de ser o responsável pelo pagamento das despesas com a programação eleitoral no rádio e na televisão.

${ }^{126}$ Há a possibilidade de a estrutura ser feita em "dobradinha", ou seja, infra-estrutura única para dois candidatos. Porém, isso se dá em candidaturas diferentes (candidato A para deputado estadual e candidato B para deputado federal), e não em candidaturas para o mesmo cargo.
} 
consolidação no atual e recente período democrático brasileiro, com fracos laços com a sociedade, denota maior possibilidade aos seus filiados candidatos na procura de potenciais doadores de campanha. Ademais, os partidos pouco influenciam também na administração das campanhas eleitorais.

O efeito nos custos de campanha proveniente da existência de candidaturas individuais nas eleições proporcionais é também detectado por Luís Virgílio Afonso da Silva, que aponta como solução a adoção do sistema de lista fechada nas eleições proporcionais brasileiras (assim como algumas propostas de reforma legislativa, conforme item 2.2), pois no sistema de lista fechada o partido é quem centraliza a arrecadação e os gastos na campanha eleitoral, não havendo mais necessidade de confecção de material de propaganda individual $^{127}$.

O inchaço do sistema partidário brasileiro, causado entre outros fatores pela possibilidade de coligações nas eleições proporcionais (vide itens 2.1.1.1 e 2.1.2.2) também pode ser apontado como uma das causas da necessidade dos candidatos buscarem cada vez mais dinheiro para suas respectivas campanhas.

Isso se deve ao fato de o grande número de partidos registrados no TSE (portanto, capazes de entrar no processo eleitoral para buscar o voto do eleitorado) majorar exponencialmente também o número de candidatos nas eleições. E quanto mais candidatos disputando, maior também a necessidade de recursos, eis que a competição também aumentou ${ }^{128}$.

Os partidos também têm papel pouco relevante na distribuição dos recursos ${ }^{129}$, já que as campanhas, majoritárias ou proporcionais, já têm o conhecimento e a estrutura necessários para a arrecadação de recursos e seus respectivos gastos.

\footnotetext{
${ }^{127}$ Cf. Luís Virgílio Afonso da Silva, Sistemas eleitorais, p. 175.

${ }^{128}$ A legislação eleitoral garante a cada partido a possibilidade de registrar até cento e cinquienta por cento o número de cadeiras a ser preenchidas na eleição proporcional em disputa (art. 10, caput, da LE). Em um exemplo hipotético, suponha-se que os 27 partidos não façam qualquer coligação para as eleições paulistas para a Câmara dos Deputados. Assim, cada partido poderá apresentar 105 candidatos às 70 cadeiras paulistas na Câmara. Multiplicado pelo número de partidos, o Estado de São Paulo terá 2835 candidatos. É forçoso reconhecer que os partidos não chegam até o limite de candidaturas disponíveis, mas ainda assim o número é bastante grande: em 2006, foram 1098 candidaturas à Câmara em São Paulo. ${ }^{129}$ Cf. David Samuels, "Financiamento de campanha e eleições no Brasil: o que podemos aprender com o 'caixa um' e propostas de reforma”, p. 372.
} 
Ademais, com um grande número de legendas, há a necessidade de se dividir entre mais partidos os recursos provenientes do Fundo Partidário e também o tempo no horário eleitoral gratuito.

Outro fator que leva ao encarecimento das campanhas eleitorais é o fato de no Brasil as circunscrições eleitorais serem territorialmente bastante grandes. Ante o número elevado de adversários e o fenômeno das candidaturas individuais, o candidato, para maximizar suas chances eleitorais, deve percorrer boa parte do território da circunscrição (eleições presidenciais - território nacional; eleições municipais município; eleições estaduais (governador, senador, deputado federal, estadual/distrital - estado) ${ }^{130}$.

Reconhece-se que há postulantes que concentram sua votação em uma região, fato que em tese diminui o custo de sua campanha. Mas além de não serem muitos os casos de concentração de votos, nota-se também que sempre há em cada região do estado ou do município outros candidatos que também terão uma maior concentração de votos na mesma localidade, acarretando maiores gastos com propaganda, por exemplo.

Por fim, outro fato que leva ao descrédito o sistema vigente de financiamento da política no Brasil, alvo conseqüentemente das críticas dos analistas do sistema políticoeleitoral brasileiro é a existência de brechas na legislação partidário-eleitoral em vigor.

Pode-se identificar como a primeira lacuna da legislação eleitoral a previsão do art. 18 da LE sobre os limites de gastos de campanha eleitoral.

Apesar de as campanhas terem que registrar o limite de seus gastos no início do período eleitoral, medida esta contribui para o melhor controle da Justiça Eleitoral e também da sociedade por servir de parâmetro de volume de gastos e do planejamento financeiro da campanha eleitoral ${ }^{131}$, o fato é que a LE determina que o limite de gastos deva ser estipulado por outra lei ordinária, menos de um mês antes do início do período

\footnotetext{
${ }^{130}$ Cf. Luís Virgílio Afonso da Silva, Sistemas eleitorais, p. 175.

${ }^{131}$ Cf. Marcelo Passamani Machado, "Financiamento das campanhas eleitorais: perspectivas para uma reforma política", p. 192.
} 
eleitoral, abrindo espaço para medidas casuísticas que venham a beneficiar determinado partido ou candidato.

Ademais, se esta lei não for editada, torna-se responsabilidade dos próprios partidos a estipulação dos seus respectivos limites, abrindo-se novo espaço para a influência negativa do poder econômico nas eleições, já que os partidos podem fixar limites suficientemente altos para jamais ultrapassá-los, e assim não serem condenados ao pagamento da multa previsto na LE por desrespeito ao limite de gastos.

A ausência de punição para as prestações de contas rejeitadas pela Justiça Eleitoral é outro motivo de crítica dos estudiosos. A única punição prevista na LE referente ao julgamento de contas eleitorais é no caso de o candidato ou comitê simplesmente não ter apresentado as mesmas à Justiça Eleitoral.

Para as eleições de 2008, consagrou-se entendimento do TSE previsto em suas Resoluções que reprovação de contas acarretaria ao candidato a sanção de não recebimento da certidão de quitação eleitoral pelo período equivalente ao da duração do mandato político disputado. Sem essa certidão, o candidato infrator não poderia ser candidato nas eleições futuras que ocorressem durante esse período.

Porém, esse entendimento do TSE que gerou a previsão da punição em suas Resoluções foi rechaçado pela Lei n. 12.034/09, que mudou a LE e determinou que somente àqueles que não apresentarem suas contas eleitorais deverão não receber a certidão de quitação eleitoral.

Outro exemplo de lacuna legislativa é a previsão de gastos eleitorais realizados por eleitor em favor de candidato (art. 27 da LE). Este dispositivo prevê que o gasto feito por um eleitor, no limite de mil UFIR ( $\$$ \$ 1.064,10), não precisa ser contabilizado na prestação de contas do candidato.

Este texto vai contra à transparência necessária ao financiamento da atividade política no Brasil, já que o candidato pode conseguir o apoio de inúmeros eleitores para que seus gastos sejam feitos todos na forma do art. 27 da LE, sem a sociedade e a 
Justiça Eleitoral terem como controlar e como ao menos serem informadas de tais gastos.

Além disso, no caso de o eleitor ultrapassar o limite legal, não há nenhuma previsão na lei sobre qual seria sua punição. Existindo a possibilidade de um eleitor fazer gasto em favor de candidato, não há também como responsabilizar o candidato beneficiado em caso de gasto de eleitor irregular.

A existência de dispositivo legal que impossibilite a identificação e a respectiva punição em caso de irregularidades no sistema normativo do financiamento da política no Brasil é criticada por Monica Herman Caggiano, eis que abre caminho para a impunidade, fato que "desprestigia qualquer sistema ou técnica de controle, por mais sofisticado que se apresente o seu mecanismo" ${ }^{, 132}$.

A precária análise das contas eleitorais é outro fator apontado como motivo para as fragilidades do sistema de financiamento da política no Brasil. Alguns aspectos convergem para essa fraca e rasa análise, entre eles a falta de estrutura da Justiça Eleitoral $^{133}$, e a necessidade de a análise ser feita muito rapidamente ${ }^{134}$ - o prazo de entrega da prestação de contas é de trinta dias após a eleição (início de novembro do ano eleitoral), sendo que a publicação do julgamento das prestações de contas dos candidatos eleitos é em até oito dias antes da diplomação, que ocorre em meados de dezembro.

Fernando Neves, ex-ministro do TSE, chega inclusive a afirmar que há entre os políticos e os magistrados eleitorais a sensação de que "os candidatos brincam de prestar contas e a Justiça finge que as examina" ${ }^{135}$.

Há também a possibilidade na legislação de adiar a publicação do nome dos doadores e das quantias doadas para as campanhas eleitorais, fato este que fulmina a

\footnotetext{
${ }^{132}$ Monica Herman Salem Caggiano, Direito parlamentar e direito eleitoral, p. 138.

${ }_{133}$ Cf. Tarcisio Viera, "Experiencias nacionales representativas: Brasil", p. 433.

${ }^{134}$ Cf. Ana Cláudia Santoro, "Os procedimentos para o financiamento de campanhas eleitorais e a problemática da prestação de contas dos recursos utilizados”, in Paraná Eleitoral, n. 52, mai./jun. 2004, p. 76.

${ }^{135}$ Fernando Neves da Silva, "Financiamento da campanha política e corrupção eleitoral", in Revista Jurídica Consulex, ano VII, n. 144, p. 38.
} 
transparência necessária para o melhor funcionamento do sistema, adiamento este dentro da lei.

Basta que no período eleitoral a empresa interessada em financiar determinada campanha, porém ocultando a doação durante período eleitoral, faça sua doação ao partido político a que o candidato é filiado.

Doando diretamente para o candidato ou para seu comitê, ele terá nome e quantia doada revelada no momento em que a prestação de contas de campanha for entregue à Justiça Eleitoral (prazo máximo de 30 dias contados da data da eleição). Se doar para o partido, haverá a publicidade da doação somente em maio do ano seguinte da eleição, já que o prazo legal para os partidos prestarem suas contas é 30 de abril.

Além disso, a doação via partido impede que haja a identificação entre doador e candidato $^{136}$, pois ao doar para a legenda, ela poderá repassar a quantia para outros candidatos seus; pode também repassar a quantia aos poucos, evitando-se assim que se perceba claramente que a empresa $\mathrm{A}$ doou para candidato $\mathrm{B}^{137}$.

Diante do quadro aqui reportado de fragilidades do sistema político-eleitoral brasileiro, surgiram reações na sociedade e no próprio Estado brasileiro, principalmente após o surgimento do escândalo do "mensalão" em meados de 2005, escândalo este que trouxe à tona as fragilidades aqui citadas, em especial no que se refere ao financiamento da atividade política no Brasil ${ }^{138}$.

Diversos projetos de lei foram apresentados por congressistas com o intuito de ao menos dirimir as fragilidades aqui apontadas. O próprio Poder Judiciário apresentou

\footnotetext{
${ }^{136}$ Em reportagem publicada no jornal Folha de S. Paulo, edição de 3.1.2010 sob manchete "Empresários vão priorizar doações ocultas na eleição", o ex-ministro do TSE Torquato Jardim, o ministro do Planejamento Paulo Bernardo e o empresário Jorge Gerdau afirmam que a doação para o partido é vantajosa justamente por não identificar a relação doador-candidato, o que vai de encontro com todo o espírito da legislação eleitoral vigente, que é o de conferir transparência às relações doador-candidato nas eleições.

${ }^{137}$ Corrobora com esta afirmação o presidente do TSE, Ministro Carlos Ayres Brito, em entrevista dada à Folha de S. Paulo e publicada na edição de 3.1.2010, p. A4.

${ }^{138}$ Monica Herman Caggiano e Marcelo Passamani Machado ressaltam que a cada novo escândalo, surgem condições políticas para que assunto tão complexo e polêmico seja discutido pela sociedade e pelos próprios políticos. (Cf. Marcelo Passamani Machado, "Financiamento das campanhas eleitorais: perspectivas para uma reforma política", p. 183 e Monica Herman Salem Caggiano, "Corrupção e financiamento das campanhas eleitorais", p. 123).
} 
uma proposta de reforma da legislação eleitoral em novembro de 2005. Já em 2008, foi a vez do Executivo apresentar seu parecer sobre as fragilidades do sistema político brasileiro, com as soluções que no seu entender são as ideais para o fim do problema.

O Legislativo, no entanto, mesmo já com uma proposta institucional já pronta, formulada em 2003 pela Comissão Especial de Reforma Política da Câmara dos Deputados, seguiu outro caminho, aprovando duas leis que alteraram a LE e a LPP, quais sejam: a Lei n. 11.300/06 e a Lei n. 12.034/09.

Estas leis, que originariamente se tratavam do PLS n. $275 / 05^{139}$ - de autoria do senador Jorge Bornhausen - e do PL n. 5.498/09 ${ }^{140}$, de autoria de quase todos os líderes de bancada da Câmara e relatado pelo deputado Flávio Dino (PC do B - Maranhão), têm como objetivo precípuo o aperfeiçoamento das normas eleitorais.

O PLS n. 275/05 visava enfrentar as fragilidades do sistema eleitoral brasileiro, principalmente no que se refere à arrecadação, gerenciamento e aplicação dos recursos de campanha por meio de "redução dos seus custos, do aperfeiçoamento dos sistemas de controle e do agravamento das punições aos infratores", eis que "a democracia representativa brasileira não resistirá por muito mais tempo aos açoites das ilegalidades que brotam das práticas correntes do financiamento de campanhas ${ }^{141142,}$.

Já o PL n. 5.498/09 tinha como escopo regulamentar as omissões existentes na legislação eleitoral, omissões estas que abriam a possibilidade de o TSE criar regras por

\footnotetext{
${ }^{139}$ Projeto de Lei do Senado n. 275/05, com texto inicial e respectiva Justificação disponível em:< http://legis.senado.gov.br/mate-pdf/6685.pdf>. Último acesso em 10.11.2009.

${ }^{140}$ Projeto de Lei n. 5.498/09 e respectiva Justificação. Autoria dos deputados federais líderes de seus respectivos partidos na Câmara Henrique Alves (PMDB - Rio Grande do Norte), Cândido Vaccarezza (PT- São Paulo), José Aníbal (PSDB- São Paulo), Ronaldo Caiado (DEM - Goiás), Rodrigo Rollemberg (PSB - Distrito Federal), Sandro Mabel (PR - Goiás), Mário Negromonte (PP - Bahia), Brizola Neto (PDT - Rio de Janeiro), Sarney Filho (PV - Maranhão), Fernando Coruja (PPS - Santa Catarina), Daniel Almeida (PC do B - Bahia), Hugo Leal (PSC - Rio de Janeiro), Carlos Willian (PTC - Minas Gerais), além da coordenadora da Bancada Feminina na Câmara, deputada federal Alice Portugal (PC do B Bahia) e do líder do Governo, deputado federal Henrique Fontana (PT - Rio Grande do Sul). Disponível em: 〈http://www.camara.gov.br/sileg/integras/668202.pdf>. Último acesso em 12.12.2009.

${ }^{141}$ Justificação do PLS n. 275/05.

${ }^{142}$ Fernando Rodrigues concorda que a Lei n. 11.300/06 teve como objetivo "reduzir custos de campanhas eleitorais, ao proibir ações e o uso de objetos considerados irrelevantes para a prática política". Porém, destaca também que a Lei contém retrocessos, em especial ao "reduzir as chances de haver renovação dos quadros políticos", eis que oferece menos condições para os iniciantes nas corridas eleitorais para fixar seu nome entre o eleitorado por meio de propaganda. (Fernando Rodrigues, Políticos do Brasil, p. 147).
} 
meio de resoluções, gerando divergências interpretativas e alongadas discussões nos processos judiciais, acarretando o fenômeno de judicialização das disputas eleitorais ${ }^{143}$. As conseqüências da adoção desses dois projetos transformados em lei serão discutidas no Capítulo 3 deste trabalho, em especial nos itens 3.1 e 3.2.

Já os três principais projetos de reformulação do cenário político brasileiro anteriormente citados, quais sejam: (i) proposta apresentada pela Comissão Especial de Reforma Política da Câmara dos Deputados; (ii) projeto de reforma eleitoral apresentada pelo TSE, elaborada por uma Comissão de Notáveis designada pelo próprio Tribunal; e (iii) proposta de reforma política apresentada pelo poder Executivo e elaborada por sua Secretaria de Assuntos Legislativos do Ministério da Justiça em 2008 serão analisados no próximo item deste capítulo.

\subsection{Possíveis remédios ao quadro político-eleitoral brasileiro: as principais propostas de Reforma Política}

Estudadas as principais críticas ao sistema político eleitoral brasileiro, neste item serão enfatizados os possíveis remédios apresentados pela sociedade para os problemas do cenário político-eleitoral nacional: as principais propostas de "reforma política" que tramitam no Congresso Nacional.

Por propostas de reforma política entendem-se todos os projetos de alteração da legislação, desde projetos de lei ordinária, passando por projetos de lei complementar e até projetos de emenda constitucional que são apresentadas não só por congressistas, mas também pelo poder Judiciário, pelo poder Executivo e até pela sociedade, por meio do mecanismo da iniciativa popular.

Neste item, porém, serão analisadas somente as propostas que tratem de alguma forma dos dispositivos legais que regem o financiamento da política no país, de modo direto (projetos que alteram, incluem ou revogam dispositivos que tratam do tema na LE, LPP, LI e CE) ou indireto (por exemplo, projetos que alteram dispositivos que

\footnotetext{
${ }^{143}$ Cf. Justificação do PL n. 5.498/09.
} 
regem a propaganda eleitoral, mas podem influir nos custos da campanha eleitoral). Foram escolhidos os três projetos, sendo cada um deles de autoria de um dos três poderes do Estado brasileiro, quais sejam: a) o projeto de lei n. 2679/2003, elaborado pela Comissão Especial de Reforma Política da Câmara dos Deputados ${ }^{144}$; b) a proposta elaborada em novembro de 2005 (em clara resposta ao aparecimento do escândalo do "Mensalão" meses antes) por uma Comissão de Notáveis criada pelo Tribunal Superior Eleitoral; e c) projeto preparado pela Secretaria de Assuntos Legislativos do Ministério da Justiça em novembro de 2008 e apresentada ao Congresso Nacional em fevereiro de 2009.

\subsubsection{Proposta da Comissão Especial de Reforma Política da Câmara dos Deputados} (Projeto de Lei n. 2.679/2003)

Desde a edição da Lei das Eleições (Lei n. 9.504/97), em setembro de 1997, imaginou-se que essa seria a lei definitiva em se tratando de questões eleitorais no Brasil. No entanto, cresceu o sentimento entre os políticos de que o país precisava passar por uma reforma ampla e profunda de seu sistema político-eleitoral.

Em 18 de fevereiro de 2003 a Câmara dos Deputados criou a Comissão Especial de Reforma Política, poucos dias após a posse dos deputados eleitos em outubro de 2002. Tal Comissão tinha como objetivo apresentar ao Plenário da Casa um projeto amplo de mudanças do sistema político-eleitoral brasileiro, e em 03 de dezembro do mesmo ano concluiu e aprovou um anteprojeto que foi transformado no Projeto de Lei n. $2679 / 2003^{145}$ a ser debatido neste subitem.

Tal projeto tem três diretrizes para o pretenso novo sistema político-eleitoral brasileiro: (i) a criação das federações partidárias; (ii) a adoção do sistema proporcional de lista fechada (ou bloqueada) e (iii) a mudança completa do sistema de financiamento das campanhas eleitorais brasileiras, que somente teriam a sua disposição recursos de origem pública.

\footnotetext{
${ }^{144}$ Foi escolhido para ser estudado o projeto de lei n. 2.679/2003, apesar de haver inúmeras outras propostas no Congresso Nacional, pelo fato de ser espécie de proposta institucional da Câmara dos Deputados, eis que elaborado por uma Comissão Especial ad hoc formada para este único fim.

${ }_{145}$ Tanto o projeto como sua justificação estão disponíveis em: 〈http://www.camara.gov.br/sileg/integras/187326.pdf〉. Último acesso em 20.11.2009.
} 
Referido projeto de lei foi apensado ao PL n. 5.268/2001 por determinação da Mesa da Câmara dos Deputados em 23 de junho de 2004. Em 21 de maio de 2007 os dois projetos foram apensados ao PL n. 8.039/1986, sendo este rejeitado pelo Plenário da Câmara em 30 de maio do mesmo ano, restando prejudicados os PL's apensados. Após, todos os projetos foram arquivados

O PL n. 2.619/2003, nas palavras dos membros da Comissão contidas na justificação da proposta, visa o saneamento de alguns dos problemas apresentados no sistema eleitoral brasileiro, problemas estes que afetam candidatos e partidos políticos, com reflexos no funcionamento do Legislativo, no Executivo e no relacionamento entre esses dois poderes, sendo mencionados taxativamente os seguintes pontos a serem resolvidos:

a) a deturpação do sistema eleitoral causada pelas coligações partidárias nas eleições proporcionais;

b) a extrema personalização do voto nas eleições proporcionais, da qual resulta o enfraquecimento das agremiações partidárias;

c) os crescentes custos das campanhas eleitorais, que tornam seu financiamento dependente do poder econômico;

d) a excessiva fragmentação do quadro partidário;

e) as intensas migrações entre as legendas, cujas bancadas no Legislativo oscilam substancialmente ao longo das legislaturas ${ }^{146}$.

Em se tratando das coligações partidárias nas eleições proporcionais, os deputados alegam que a fórmula diante da fórmula do quociente eleitoral prevista no $\mathrm{CE}$, resta a muitos partidos - na tentativa de obter ao menos uma cadeira na Casa Legislativa em disputa - a alternativa de formar aliança com uma legenda mais poderosa eleitoralmente ou até financeiramente, no intuito de superar a barreira do quociente.

Conforme análise contida no item 2.1.1.1, o eleitorado em sua grande maioria ignora tal mecanismo, mecanismo este que possibilita uma espécie de transferência de votos para um partido no qual o eleitor não votou. Esta possibilidade também é criticada

\footnotetext{
${ }^{146}$ Justificação do projeto de lei n. 2.679/2003, p. 14-15.
} 
pelos membros da Comissão, conforme se apreende da justificação do projeto ora em debate:

A prática dilui as diferenças entre os partidos, parecendo servir apenas de expediente para burlar a barreira legal. Além disso, a não-permanência da coligação após o pleito, no trabalho legislativo, acentua o caráter oportunista e episódico da aliança. Da perspectiva do eleitor comum, portanto, subtrai-se inteligibilidade do sistema e, no médio prazo, pode afetar-se a própria legitimidade da representação ${ }^{147}$.

A proposta para a correção deste ponto é banir do ordenamento a possibilidade de coligação nas eleições proporcionais, revogando-se o art. 105 do CE. Apesar da proposta de banimento das coligações nas eleições proporcionais, o projeto prevê a criação do instituto da "federação partidária", tendo como justificativa a defesa dos partidos pequenos de caráter histórico, que "legitimamente se propõem a difundir suas idéias e princípios na vida política ${ }^{148,}$.

A "federação partidária" consiste na possibilidade de dois ou mais partidos políticos reunir-se, constituir a federação de registrá-la perante o TSE, atuando após como se fosse um único partido, inclusive no registro de candidaturas, no funcionamento parlamentar, preservando a identidade e a autonomia dos partidos federados. Essa nova forma de aliança, porém, têm regras próprias para subsistir e concorrer nas eleições, entre elas: (i) os partidos federados deverão permanecer neste regime por pelo menos três anos; (ii) o prazo máximo para a constituição da federação é de quatro meses antes das eleições; (iii) ao registrar-se perante o TSE, a federação deve apresentar as resoluções tomadas - por maioria absoluta de cada órgão nacional partidário - por cada partido federado, além de um programa e um estatuto comum e a ata da eleição do órgão de direção nacional da federação. A pena, em caso de descumprimento destas regras, é a perda do direito do funcionamento parlamentar.

O PL n. 2.679/2003 também muda o art. 13 da LPP, que trata da cláusula de desempenho $^{149}$ existente para diminuir o número de partidos com funcionamento

\footnotetext{
${ }^{147}$ Justificação do projeto de lei n. 2.679/2003, p. 15-16.

148 Justificação do projeto de lei n. 2.679/2003, p. 16.

149 Conforme analisado no item 2.1.1.2, a cláusula de desempenho presente no art. 13 da LPP foi considerada inconstitucional pelo STF em dezembro de 2006.
} 
parlamentar em todas as casas legislativas do país, diminuindo a porcentagem de votos a ser obtida pelos partidos para ter direito ao funcionamento parlamentar de $5 \%$ para $2 \%$ dos votos amealhados em todo o território nacional nas eleições para a Câmara dos Deputados, além de determinar que os partidos tenham estes votos distribuídos em pelo menos um terço dos Estados, elegendo ao menos um representante em cinco desses Estados.

Apesar da eliminação da possibilidade de coligação em eleições proporcionais, o projeto defende a criação de um novo tipo de aliança partidária e propõe a diminuição da porcentagem da cláusula de desempenho prevista na LPP, justificando tais mudanças como forma de proteger os pequenos partidos com caráter histórico.

Diante de tal quadro, pode-se perceber uma proposta paradoxal: retira-se a possibilidade de coligação nas eleições proporcionais (classificada na própria Justificação do projeto como espécie de burla e também como facilitadora de alianças de caráter exclusivamente eleitoral e que afetam a inteligibilidade do sistema e a própria representatividade política), mas ao mesmo tempo cria outras condições para que os partidos políticos ainda possam ganhar força (as federações e a diminuição da cláusula de desempenho).

Eurico A. Gonzalez Cursino dos Santos, ao analisar o projeto, conclui da mesma forma, conforme trecho a seguir:

$\mathrm{Na}$ justificação do projeto, fica clara a motivação da criação da "federação" partidária: ela "permitirá aos pequenos partidos contornar o obstáculo do quociente eleitoral". Ora, se considerarmos a real motivação da federação partidária (criar uma exceção ao princípio tutelado pela lei), e observarmos que o Projeto de Lei $\mathrm{n}^{\circ}$ 2.679, de 2003, ainda reduz o quociente partidário, de cinco para dois por cento, além de trocar a exigência de votação mínima de dois por cento do total de votos por partido em pelo menos um terço dos Estados pela exigência de eleger-se ao menos um representante em cinco Estados daquele terço, então não podemos nos furtar à conclusão de que o projeto contradiz-se a si mesmo. Isso porque a 
fragmentação partidária foi identificada como um dos problemas a serem sanados pela iniciativa em exame. ${ }^{150}$

A Comissão Especial de Reforma Política da Câmara dos Deputados também defende a adoção do sistema de lista fechada para as eleições proporcionais brasileiras. Assim sendo, ao contrário do sistema vigente hoje no país, no qual o eleitor pode votar tanto na legenda como em um candidato individualmente, o país deveria adotar a lista fechada, lista essa a ser feita pelo partido (ou federação partidária, conforme projeto) em convenção a ser realizada no mês de junho do ano eleitoral. Essa lista, porém, será preordenada, não havendo a possibilidade de o eleitor não filiado ao partido influenciar em sua ordem numérica.

A lista de candidatos será elaborada em âmbito estadual (ou seja, para as eleições de deputado federal e estadual) na Convenção partidária estadual por voto secreto dos convencionais, havendo na eleição municipal convenção para também formular a lista para a eleição de vereador.

A ordem decrescente dos votos obtidos pelos candidatos na Convenção corresponderá a ordem da lista apresentada ao eleitorado, sendo que cada convencional disporá de três votos, sendo permitido votar mais de uma vez no mesmo candidato. Há a obrigatoriedade de reserva de ao menos $30 \%$ das vagas para candidaturas de cada sexo (há a reserva de vaga, porém sem qualquer prevalência na ordem da lista), devendo o estatuto dispor sobre a ordem de preferência dos candidatos na lista de eventual federação. O número de candidatos de cada lista partidária deve ter no máximo o número de candidatos correspondente a $150 \%$ do número de vagas na Casa Legislativa.

Após a apuração dos votos, estarão eleitos tantos candidatos por partido ou federação quantos o respectivo quociente partidário indicar, na ordem em que forem registrados. Ou seja, se o partido ABC conseguir cinco cadeiras para a Câmara Municipal de São Paulo serão eleitos os cinco primeiros da lista partidária.

\footnotetext{
${ }^{150}$ Eurico A. Gonzalez Cursino dos Santos. "Comentários ao PL 2.679/2003, da Comissão de Reforma Política da Câmara dos Deputados". Revista de Informação Legislativa, ano 41, n. 161, jan./mar. 2004, p. 18.
} 
Ademais, o art. $6^{\circ}$ do projeto prevê que os filiados que já detêm mandato teriam prioridade no posicionamento da lista partidária, de acordo com a votação recebida na eleição de $2002^{151}$.

Os membros da Comissão elaboradora do projeto alegam na justificação da proposta que o sistema vigente de lista aberta é nocivo para a disciplina e coesão partidárias, além do fato de que os candidatos aos mandatos proporcionais enfrentam o período eleitoral em estratégias e esforços individuais, "inclusive no financiamento de campanhas, certamente seu comportamento com relação ao partido não terá as mesmas características que teria, caso o partido fosse relevante para a escolha dos eleitores ${ }^{152 \%}$.

O fortalecimento dos partidos é o objetivo do projeto neste tema. Argumentam os membros da Comissão que o partido é fundamental para a democracia representativa, pois são as legendas quem podem arregimentar líderes, "fazer campanhas em torno de plataformas" e "atuar disciplinadamente no Legislativo", já que "o funcionamento da democracia requer interlocutores confiáveis e permanentes ${ }^{153}$ \%. O fortalecimento desejado justifica-se, na visão dos membros da Comissão, de que atualmente os parlamentares votam os projetos apresentados no Legislativo não por serem adeptos aos princípios e programas partidários, mas sim pela busca de vantagens individuais ${ }^{154}$.

Superado esse problema com o fortalecimento dos partidos, o eleitorado terá melhores condições de acompanhar as questões debatidas no Legislativo, eis que segundo os congressistas membros da Comissão Especial, os legisladores serão mais disciplinados e os partidos mais coesos, melhorando também a relação entre o Legislativo e o Executivo, conforme trecho a seguir:

\footnotetext{
151 “Art. $6^{\circ}$ Os atuais detentores de mandato de Deputado Federal, Estadual e Distrital que, até a véspera da convenção para escolha de candidatos, fizerem comunicação por escrito, ao órgão de direção regional, de sua intenção de concorrer ao pleito, comporão a lista dos respectivos partidos ou federações, na ordem decrescente dos votos obtidos nas eleições de 2002, salvo deliberação em contrário do órgão competente do partido.

$\S 1^{\circ} \mathrm{O}$ ordenamento da lista a que se refere o caput obedecerá aos seguintes critérios:

I - primeiramente, na ordem decrescente da votação obtida no pleito de 2002, os candidatos originários, isto é, os eleitos pelo próprio partido ou em coligação com este, os suplentes efetivados e os suplentes que exerceram o mandato por, pelo menos, seis meses até 31 de dezembro de 2003;

II - a seguir, os candidatos que houverem mudado de legenda partidária após o pleito de 2002, respeitada, igualmente, a ordem da votação obtida.

${ }_{152}$ Justificação do projeto de lei n. 2.679/2003, p. 17.

${ }^{153}$ Justificação do projeto de lei n. 2.679/2003, p. 18.

${ }^{154}$ Justificação do projeto de lei n. 2.679/2003, p. 19.
} 
Os partidos organizados são capazes de fazer compromissos e cumpri-los, de interagir responsavelmente uns com os outros nas negociações no plano do Legislativo e na composição dos governos de coalizão, que em nosso país são a forma habitual de exercício do Poder Executivo. Em suma, os partidos trazem segurança à vida política e permitem a formação de expectativas razoáveis sobre seus comportamentos futuros, exigência da vida moderna para todos os agentes responsáveis no âmbito público ${ }^{155}$.

Há, porém, variadas críticas ao sistema proposto pela Comissão de deputados. A primeira delas é que a adoção da lista fechada fará com que o legislador fique ainda mais distante do eleitorado ${ }^{156}$, eis que não dependerá mais dos votos do eleitor comum para ser eleito, mas sim do contato exclusivamente com os filiados de seu partido para conseguir uma posição razoável na lista partidária. A campanha eleitoral, com a adoção da lista fechada, é exclusivamente partidária, e não mais individual, fato este que inevitavelmente gerará um número menor de possibilidade de contato entre eleitor e candidato.

Luís Virgílio Afonso da Silva assevera que a adoção da lista fechada diminuirá sobremaneira o personalismo das candidaturas proporcionais, mas defende que os candidatos não permanecerão tão distantes do eleitorado. $\mathrm{O}$ autor também afirma, em concordância com a argumentação contida na justificação dos deputados membros da Comissão, que os partidos saem fortalecidos com a eventual adoção da lista fechada, em decorrência do fato de que o eleitor também votará de modo mais preocupado com aspectos partidários, como o programa e a ideologia. Tal alegação pode ser verificada pelo trecho a seguir:

Esse fato [a adoção da lista fechada] tende, a longo prazo, a diminuir o personalismo dominante nas eleições, porque, em primeiro lugar, nenhum candidato dependerá de sua votação para ser eleito, devendo todos lutar em conjunto para que seu partido tenha o maior número possível de votos e, em segundo lugar, porque os eleitores deverão votar em um partido, o que fará com que os votos tenham, com o passar do tempo, um conteúdo mais ideológicoprogramático do que pessoal ${ }^{157}$.

\footnotetext{
${ }^{155}$ Justificação do projeto de lei n. 2.679/2003, p. 19.

${ }^{156}$ Cf. Eurico A. Gonzalez Cursino dos Santos. "Comentários ao PL 2.679/2003, da Comissão de Reforma Política da Câmara dos Deputados", p. 16.

${ }^{157}$ Luís Virgílio Afonso da Silva. Sistemas eleitorais, p. 175.
} 
Outra provável conseqüência da adoção do sistema de lista fechada é o fortalecimento da burocracia e das lideranças partidárias, pois elas são quem coordenarão as mudanças estatutárias dirigidas para a escolha da ordem da lista partidária, além de comandar as Convenções em que serão elaboradas as listas.

Luís Virgílio Afonso da Silva reconhece a probabilidade de tal efeito, e defende que somente a adoção de mecanismos democráticos intrapartidários pode afastar tal problema $^{158}$.

Por fim, a terceira base do projeto ora discutido é a adoção do financiamento público das campanhas eleitorais. Em relação ao financiamento dos partidos políticos, o projeto altera o art. 39 da LPP de forma paradoxal, eis que mantém a possibilidade de doação de dinheiro com origem de pessoas físicas e pessoas jurídicas privadas, havendo somente a proibição do uso de tais recursos em campanhas eleitorais ${ }^{159}$. Tais recursos privados poderiam, inclusive, servir para pagar propaganda doutrinária e política, desde que não feitas em período eleitoral. Há também a previsão de dirigir $30 \%$ dos recursos destinados obrigatoriamente às fundações partidárias em programas para o estímulo e crescimento da participação política feminina.

No que toca às mudanças na LE, a responsabilidade pelas despesas da campanha (art. 17 da Lei n. 9.504/97) seria exclusiva do partido. As campanhas eleitorais de todo o país teriam à disposição um montante do orçamento da União estabelecido da seguinte forma: valor equivalente ao número de eleitores do País existente em 31 de dezembro do ano anterior à elaboração da lei orçamentária multiplicado por $\mathrm{R} \$ 7,00$ (sete reais).

O Tesouro Nacional, até $01^{\circ}$ de maio do ano do pleito, deve fazer o depósito do montante em conta especial do TSE no Bando do Brasil. Dentro de dez dias após o referido depósito, o TSE fará a distribuição dos recursos aos órgãos de direção nacional dos partidos, obedecendo aos seguintes critérios:

\footnotetext{
${ }^{158}$ Cf. Luís Virgílio Afonso da Silva. Sistemas eleitorais, p. 177.

159 “Art. 39. Ressalvado o disposto no art. 31, o partido político ou federação pode receber doações de pessoas físicas e jurídicas para a constituição de seus fundos, sendo vedado usá-los no financiamento de campanhas eleitorais".
} 
a) $1 \%$ dividido igualitariamente entre todos os partidos e federações registrados no TSE;

b) $14 \%$ divididos igualitariamente entre os partidos e federações com representação na Câmara dos Deputados;

c) $85 \%$ a serem divididos entre os partidos e federações proporcionalmente ao número de representantes na Câmara dos Deputados.

Nas eleições gerais (nacional e estadual), se o partido ou federação tiver candidato à Presidência da República, 30\% de seus recursos deverão ser destinados a esta campanha. Se não tiver candidato ao Planalto, mas estiver em coligação com outra legenda, deve reservar $20 \%$ dos recursos à campanha presidencial.

Reservados os recursos à corrida presidencial, os diretórios partidários nacionais devem distribuir os recursos restantes da seguinte forma:

a) metade na proporção do número de eleitores de cada Estado, do Distrito Federal e de cada Território; e

b) metade na proporção das bancadas dos Estados, do Distrito Federal e dos Territórios, que o partido ou federação elegeu para a Câmara dos Deputados.

Em caso de eleição municipal, os diretórios nacionais reservam $10 \%$ dos recursos para si e distribuem os outros $90 \%$ entre os diretórios regionais. Estes reservam $10 \%$ para sua administração direta e distribuem os outros $90 \%$ para os diretórios municipais, porcentagem esta distribuída da seguinte forma:

a) metade na proporção do número de eleitores do município; e

b) metade na proporção do número de vereadores eleitos pelo partido político ou federação, no município, em relação ao total de vereadores eleitos pelo partido político ou federação no Estado.

As campanhas eleitorais serão financiadas exclusivamente com o dinheiro desta dotação orçamentária, sendo vedada a doação de pessoa física ou jurídica e também o uso de recurso do próprio partido. Os partidos devem, 45 dias antes da eleição, apresentar uma prestação de contas parcial, apresentando a prestação complementar (referente aos dias posteriores ao da primeira prestação) em até dez dias após a eleição. 
Caso haja doação de fonte vedada, o doador está sujeito à multa de cinco a dez vezes o valor doado, sendo que a pessoa jurídica infratora também será proibida de firmar contratos com o Poder Público e participar de licitações por cinco anos. Já o partido que recebeu a doação paga multa no valor de três vezes o valor doado ilegalmente.

O candidato majoritário infrator está sujeito à cassação do registro de candidatura ou do diploma, se este já tiver sido expedido. Já o postulante a cargo proporcional, se comprovada sua responsabilidade, está sujeito às mesmas penas do candidato majoritário, sem prejuízo de ser responsabilizado por abuso de poder econômico, conforme penas cominadas no art. 23, inciso III da Lei n. 8.884, de 11 de junho de $1994^{160}$. Se comprovada a responsabilidade do partido ou federação, serão cassados o registro da lista partidária (ou seja, o registro de todos os candidatos) ou os diplomas dos postulantes, se já expedidos.

Por fim, o projeto prevê a inclusão do art. 25-A na LE. Referido artigo dispõe sobre a criação de uma comissão constituída pela Justiça Eleitoral em cada circunscrição, com composição, atribuições e regras de funcionamento a serem definidas pelo TSE com poderes para, liminarmente, determinar a suspensão da campanha do candidato ou da lista, no caso de haver doação ilegal, por um prazo máximo de cinco dias, havendo garantia de ampla defesa ${ }^{161}$.

\footnotetext{
160،“Art. 23. A prática de infração da ordem econômica sujeita os responsáveis às seguintes penas: (...)

III - No caso das demais pessoas físicas ou jurídicas de direito público ou privado, bem como quaisquer associações de entidades ou pessoas constituídas de fato ou de direito, ainda que temporariamente, com ou sem personalidade jurídica, que não exerçam atividade empresarial, não sendo possível utilizar-se o critério do valor do faturamento bruto, a multa será de 6.000 (seis mil) a 6.000 .000 (seis milhões) de Unidades Fiscais de Referência (Ufir), ou padrão superveniente".

161 "Art. 25-A. A fiscalização de abuso do poder econômico, no curso da campanha, será exercida por uma comissão instituída pela Justiça Eleitoral, em cada circunscrição.

$\S 1^{\circ}$ A composição, atribuições e funcionamento da comissão serão disciplinados pelo Tribunal Superior Eleitoral.

$\S 2^{\circ}$ Entre os membros da comissão constarão os representantes dos partidos, federações, coligações e outros que a Justiça Eleitoral considerar necessários.

$\S 3^{\circ}$ Por solicitação da comissão, o órgão competente da Justiça Eleitoral poderá, liminarmente, determinar a suspensão da campanha do candidato ou da lista, nas hipóteses previstas nos $\S \S 4^{\circ}$ e $5^{\circ}$ do art. 24, pelo prazo máximo de cinco dias, assegurada ampla defesa".
} 
Apontado pelos deputados membros da Comissão Especial como um "dos maiores desafios que enfrentam as democracias ${ }^{162}$,, o projeto propõe, a adoção do sistema do financiamento das campanhas eleitorais com recurso de origem exclusivamente pública.

Tal proposta é feita em virtude do fato de que as campanhas atualmente carecem cada vez mais de vultosa quantia de dinheiro, eis que suas características básicas deixaram de existir (atuação da militância de modo voluntário, por exemplo) e são baseadas cada vez mais na mídia televisiva ${ }^{163}$.

Ante a necessidade premente de dinheiro para a sustentação financeira das campanhas e do fato de os recursos advindos do Fundo Partidário previsto na LPP ser absolutamente insuficientes, os partidos e os candidatos devem buscar esses recursos em pessoas e empresas interessadas em financiar campanhas eleitorais.

O sistema de financiamento vigente no país gera, segundo os membros da Comissão Especial, máculas à normalidade e à legitimidade das eleições, eis que se constrói uma espécie de vínculo de dependência entre o financiador e o candidato financiado, além de perverter a igualdade entre os candidatos, pois quem amealhar mais recursos provavelmente terá melhores chances de vencer a eleição ${ }^{164}$.

Ressaltam os congressistas que a adoção do sistema de financiamento exclusivamente público das campanhas eleitorais é conflitante com as eleições proporcionais no modo de lista aberta, pela razão já estudada anteriormente no item 2.1.1.1: a possibilidade de campanhas individualizadas. Pode-se compreender melhor tal argumento com o trecho a seguir:

O financiamento público exclusivo é, porém, incompatível com a sistemática atual do voto em lista aberta. A campanha em bases individuais, peculiar a essa modalidade, exigiria a divisão da dotação partidária pelos candidatos. Os recursos se diluiriam e, certamente, teriam de ser complementados com recursos de outras fontes, e o sistema estaria comprometido ${ }^{165}$.

\footnotetext{
162 Justificação do projeto de lei n. 2.679/2003, p. 19.

${ }^{163}$ Cf. Justificação do projeto de lei n. 2.679/2003, p. 19-20.

${ }^{164}$ Cf. Justificação do projeto de lei n. 2.679/2003, p. 20.

165 Justificação do projeto de lei n. 2.679/2003, p. 20.
} 
Prosseguem os congressistas, argumentando que com a adoção do sistema proporcional de lista fechada, os custos com as campanhas eleitorais cairiam abruptamente, pois a campanha seria centralizada pelo partido político.

Ademais, como a batalha entre os candidatos do mesmo partido se dá em período pré-eleitoral - na fase das Convenções - e não mais durante a campanha eleitoral, os candidatos unir-se-iam para o sucesso do partido na eleição proporcional, com o intuito de eleger mais representantes.

Por fim, a combinação da lista fechada com o financiamento exclusivamente público das campanhas eleitorais facilitaria sobremaneira a fiscalização das prestações de contas pela Justiça Eleitoral, eis que ao invés de proceder à análise de milhares de contas individualizadas, fará somente a verificação das contas de campanhas de cada partido:

Com financiamento a partidos que apresentam listas fechadas, a campanha eleitoral será da agremiação como um todo. Os programas eleitorais, os comícios, a propaganda, enfim, serão empreendimentos partidários, devendo todos trabalhar pela causa comum. O custo da campanha poderá diminuir sensivelmente e mais se reforçará a legitimidade do processo político. Também a fiscalização dos pleitos pela Justiça Eleitoral tornar-se-á muito mais simples, pois em vez de deparar-se ela com milhares de prestações de contas, produzidas por milhares de candidatos, examinará um número reduzido delas, de responsabilidade os próprios partidos ${ }^{166}$.

Corrobora com a afirmação acima exposta Luís Virgílio Afonso da Silva, ao asseverar que com a lista fechada, haveria a redução dos custos da campanha e também da influência do poder econômico, pois não haveria mais a necessidade de se produzir, por exemplo, material de campanha de forma individualizada ${ }^{167}$.

Eurico A. Gonzalez Cursino dos Santos aponta com clareza a principal falha do projeto ora em comento, que é a falta de regulamentação das convenções partidárias para a escolha da lista partidária e de sua respectiva ordem.

\footnotetext{
166 Justificação do projeto de lei n. 2.679/2003, p. 20-21.

${ }^{167}$ Cf. Luís Virgílio Afonso da Silva. Sistemas eleitorais, p. 175.
} 
O autor detecta que diante desta proposta, apenas haverá o deslocamento temporal da influência do poder econômico nas eleições: em vez de ocorrer no período de campanha (de julho a outubro do ano eleitoral), acontecerá em junho, durante as convenções, eis que não há qualquer regra de controle para o financiamento da atividade pré-eleitoral no país (na legislação vigente, há apenas a proibição de doações às campanhas que ocorram antes da constituição do comitê financeiro e da abertura de conta corrente específica para a arrecadação de dinheiro para a sustentação da campanha) ${ }^{168}$.

Soma-se a esta constatação a possibilidade prevista no projeto de os partidos captarem recursos por meio de doações de pessoas físicas e jurídicas aos partidos em período não-eleitoral, fato este que adicionado à ausência de controle do período de Convenções sugere a sobrevivência da influência do poder econômico privado nos partidos e por conseqüência nas campanhas eleitorais.

Depreende-se da análise do projeto que a adoção do financiamento exclusivamente público como ora proposto acarretará também ao crescimento da força dos líderes e da burocracia partidária, eis que o órgão de direção nacional será o responsável pela distribuição do dinheiro aos diretórios regionais e municipais, trazendo a possibilidade de os chefes do partido beneficiar os candidatos mais próximos aos seus interesses e prejudicar aqueles mais distantes.

Apesar de o projeto prever critérios para a distribuição da quantia recebida do Tesouro Nacional, não há qualquer dispositivo que trate do período temporal a ser realizado tal repasse, abrindo-se a probabilidade de o Diretório procrastinar em realizar a distribuição do dinheiro, prejudicando assim o planejamento financeiro de determinada candidatura.

Analisada a principal proposta de reforma política originária no Congresso Nacional, será analisa a proposta apresentada pelo poder Judiciário para a melhoria do sistema político-eleitoral brasileiro.

\footnotetext{
${ }^{168}$ Cf. Eurico A. Gonzalez Cursino dos Santos. "Comentários ao PL 2.679/2003, da Comissão de Reforma Política da Câmara dos Deputados”, p. 18.
} 


\subsubsection{Proposta da Comissão de Notáveis do Tribunal Superior Eleitoral}

Logo após o surgimento do escândalo do "Mensalão", em junho de 2005, o Tribunal Superior Eleitoral, presidido na época pelo ministro Carlos Velloso, criou uma Comissão de Notáveis no sentido de preparar uma proposta para a modernização do sistema eleitoral brasileiro, com foco principalmente no combate à existência do chamado "caixa dois" de campanha ${ }^{169}$.

O "caixa dois" de campanha tem como base a dependência dos candidatos dos recursos de origem privada para o financiamento de suas campanhas, e caracteriza-se pela não declaração na respectiva prestação de contas de recursos doados por pessoas físicas ou jurídicas, independentemente da legalidade da origem do recurso.

Concluído o projeto pela Comissão de Notáveis em novembro do mesmo ano, o presidente do TSE apresentou a proposta ao presidente do Senado à época, senador Renan Calheiros (PMDB-Alagoas), que protocolizou o projeto para apreciação da Casa (Projeto de Lei do Senado n. 389/2005) ${ }^{170}$. O projeto seguiu para a Comissão de Constituição e Justiça da Casa, aguardando ser incluído em pauta para a votação dos membros da Comissão desde 19 de fevereiro de 2009

Com o foco no combate ao "caixa dois" de campanha, o projeto em voga propõe algumas mudanças na legislação eleitoral, em especial: (i) endurecimento das penas previstas no CE para os crimes eleitorais; (ii) criação de um novo tipo penal: o ato de realizar "caixa dois" em campanhas eleitorais; (iii) conferir mais agilidade aos julgamentos das prestações de contas de campanha; (iv) alterar a LI no que tange à repressão ao abuso do poder econômico; e (v) criar um incentivo fiscal para as doações para as campanhas eleitorais.

\footnotetext{
${ }^{169}$ A feitura de tal projeto como espécie de reação ao escândalo do "Mensalão", em resposta à sociedade brasileira, fica clarividente diante da afirmação de Walter Costa Porto, membro da Comissão da Comissão de Notáveis, na publicação editada pelo TSE contendo a proposta ora em análise: $A$ preocupação de agora resultou dos tão graves acontecimentos envolvendo a descoberta, na prestação de contas dos partidos, de recursos não declarados - o "caixa dois", tão deplorada pelos meios de comunicação - a enodoar a trajetória de nossas agremiações. Walter Costa Porto. "O TSE e a reforma eleitoral-partidária", in Brasil. Tribunal Superior Eleitoral. Reforma eleitoral: delitos eleitorais, prestação de contas (partidos e candidatos), propostas do TSE. - Brasília: SDI, 2005, p. 10.

${ }_{170}$ Projeto disponível em: <http://www.senado.gov.br/sf/atividade/materia/getPDF.asp?t=36161>. Último acesso em 20.11.2009.
} 
O projeto prevê uma alteração completa na tipificação e nas penas para os crimes previstos no CE. Este trabalho, porém, analisará somente os dispositivos tipificadores relacionados ao sistema de financiamento da política no Brasil, foco principal da obra.

Em relação à alteração no direito penal eleitoral, têm relação com o financiamento da política os seguintes artigos do projeto elaborado pela Comissão de Notáveis do TSE: (i) art. 305 - doação acima do limite legal; (ii) art. 339 - crime de "caixa dois" ou de movimentação paralela de recursos de campanha; (iii) art. 340 omissão de dados na prestação de contas; e (iv) art. 345 - recebimento de recursos de fontes vedadas.

$\mathrm{O}$ art. 305 proposto $^{171}$, que foi classificado como crime contra a propaganda eleitoral,tem como escopo punir o doador e também quem recebeu uma doação feita acima dos limites estabelecidos em lei ${ }^{172}$.

O mesmo artigo proposto traz lista exaustiva do que é considerado criminalmente recurso para campanha eleitoral, contendo também uma previsão para o aumento de pena: (se o agente foi dirigente partidário) e outra para diminuição da pena

\footnotetext{
171 “Art. 305 Doar, direta ou indiretamente, a partido, coligação ou candidato, recursos destinados à campanha eleitoral, em valor superior ao estabelecido em lei:

Pena - detenção, de 1(um) a 3 (três) anos, e multa.

$\S 1^{\circ} \mathrm{Na}$ mesma pena incorre quem receber ou gastar os recursos em desacordo com a determinação da lei.

$\S 2^{\circ}$ Consideram-se recursos:

a) quantia em dinheiro, em moeda nacional ou estrangeira;

b) título representativo de valor mobiliário;

c) qualquer mercadoria de valor econômico;

d) a prestação, gratuita ou por preço significativamente inferior ao do mercado, de qualquer serviço, ressalvada a oferta de mão-de-obra por pessoa física;

e) a utilização de qualquer equipamento ou material;

f) a difusão de propaganda, por qualquer meio de comunicação social, ou o pagamento das despesas necessárias à sua produção e veiculação;

g) a cessão, temporária ou definitiva, de bem imóvel;

h) o pagamento de salário ou qualquer outra forma de remuneração a prestador de serviço ou empregado de partido ou de candidato;

i) o pagamento, a terceiro, de despesas relativas às hipóteses previstas neste artigo.

$\S 3^{\circ} \mathrm{A}$ pena será aumentada se o agente for dirigente partidário.

$\S 4^{\circ}$ A pena será diminuída nas hipóteses das alíneas d e g, ou em qualquer outra quando o recurso aportado não ultrapassar o dobro do valor estabelecido em lei".

${ }^{172}$ Os limites são aqueles dispostos no art. $23, \S 1^{\circ}$, inciso I e art. $81, \S 1^{\circ}$ da LE.
} 
- se ocorrer as condutas previstas nas alíneas "d" (prestação de serviço gratuita ou por preço inferior ao de mercado) e "g" (cessão, temporária ou definitiva, de bem imóvel).

Também será diminuída a pena, em qualquer conduta irregular com os recursos previstos em quaisquer das alíneas sugeridas, se o recurso aportado não ultrapassar o dobro do valor estabelecido em lei.

Cabe aqui fazer duas observações referentes ao artigo ora estudado: o caput do artigo prevê doações para coligações, fato este vedado pela LE, que determina que a responsabilidade da administração financeira da campanha é dos partidos e dos candidatos (art. 17 da LE). Ademais, os $\S \S 3^{\circ}$ e $4^{\circ}$ do artigo proposto não estabelece em quanto as penas serão aumentadas ou diminuídas, se for o caso.

Denise Goulart Schlickmann e Heloísa Helena Bastos Silva Lübke defendem que nesses dois casos, cabe ao juiz, ao julgar o caso concreto, analisar as circunstâncias que podem ensejar o aumento ou a diminuição da pena, da forma que entender mais apropriado $^{173}$.

Já o crime previsto no art. 339 proposto $^{174}$ é a principal novidade deste projeto no que concerne aos crimes eleitorais, eis que tipifica o ato de movimentar recursos de campanha de forma paralela, ato este conhecido como "caixa dois". Trata-se de crime contra a administração da Justiça Eleitoral, cujo bem protegido é a lisura das prestações de contas das campanhas eleitorais. Denise Schlickmann e Heloísa Lübke definem “caixa dois" como "a realização de manobras contábeis com vistas a obter, esconder,

\footnotetext{
${ }^{173}$ Cf. Denise Goulart Schlickmann e Heloísa Helena Bastos Silva Lübke. "Financiamento de campanhas eleitorais: avaliação das propostas apresentadas pelo Tribunal Superior Eleitoral ao Congresso Nacional", Resenha eleitoral: nova série, v. 15, 2008, p. 134.

174 "Art. 339. Manter ou movimentar recurso ou valor paralelamente à contabilidade exigida pela legislação para a escrituração contábil de partido político e relativa ao conhecimento da origem de suas receitas e a destinação de suas despesas:

Pena - reclusão, de 3 (três) a 8 (oito) anos, e multa, além da perda dos recursos ou valores.

$\S 1^{\circ}$ A pena será aumentada quando se tratar de recurso ou valor referente à prestação de contas de campanha eleitoral.

$\S 2^{\circ}$ Incorrerá na mesma pena quem receber recurso ou valor proveniente de atividade ilícita ou não declarado pelo doador ao órgão competente".
} 
manipular ou utilizar recursos, financeiros ou não, de forma a ferir as normas estabelecidas para a contabilidade das agremiações partidárias" ${ }^{175}$.

A natureza dos recursos movimentados paralelamente pode ser tanto legal ou ilegal. Ou seja, a utilização de dinheiro de fonte permitida para custeio da campanha ou do funcionamento partidário, porém sem a devida contabilização preenche os requisitos legais para a punição do infrator. Se for recurso advindo de fonte vedada, há também o cometimento do crime do art. 345 proposto.

No artigo proposto ora em comento, não há qualquer parâmetro tanto mínimo como máximo para a aplicação da multa prevista como pena. Prevê o $\S 1^{\circ}$ do artigo proposto o aumento da punição caso o recurso manejado irregularmente seja referente à administração de campanhas eleitorais. Também não há qualquer parâmetro para a aplicação do aumento da pena por parte do juiz eleitoral.

Os sujeitos ativos do tipo são o tesoureiro do partido e os dirigentes partidários responsáveis pela administração financeira da legenda, no caso de recursos gerido para o funcionamento e manutenção do partido (art. 34, inciso II da LPP); e o candidato, o administrador da campanha (se houver) e os membros do comitê financeiro, no caso de recurso de campanha eleitoral (art. 21 da LE).

O texto do $\S 2^{\circ}$ gera dúvida quanto ao âmbito a ser aplicada a pena prevista: vale apenas para as campanhas eleitorais ou também para a administração irregular dos recursos partidários? Denise Schlickmann e Heloísa Lübke defendem que a previsão contida no $\S 2^{\circ}$ vale para os dois casos, conforme alegação a seguir:

Examinando-se o dispositivo pela ótica do bem jurídico tutelado, tem-se que, em última instância, tanto a integridade das instituições constitucionalmente necessárias à democracia representativa como a lisura do processo eleitoral são situações que estariam abrangidas pela norma. ${ }^{176}$

\footnotetext{
${ }^{175}$ Denise Goulart Schlickmann e Heloísa Helena Bastos Silva Lübke. "Financiamento de campanhas eleitorais: avaliação das propostas apresentadas pelo Tribunal Superior Eleitoral ao Congresso Nacional", p. 135.

${ }^{176}$ Denise Goulart Schlickmann e Heloísa Helena Bastos Silva Lübke. "Financiamento de campanhas eleitorais: avaliação das propostas apresentadas pelo Tribunal Superior Eleitoral ao Congresso Nacional", p. 136.
} 
No caso de condenação por conduta tipificada neste artigo, há a imediata cassação do mandato eletivo, conforme se depreende do texto do art. 293, inciso III proposto ${ }^{177}$.

Em se tratando do crime de omissão de dados na prestação de contas (art. 340 proposto $)^{178}$, o bem jurídico tutelado novamente é a lisura das prestações de contas eleitorais e partidárias, sendo a conduta típica deixar de apresentar à Justiça Eleitoral qualquer tipo de informação referente à administração financeira da campanha eleitoral ou do partido político, ou outro tipo de informação exigida pela Justiça Eleitoral por conta da prestação da administração financeira. Como no artigo comentado anteriormente, podem ser sujeitos ativos os coordenadores financeiros partidários ou de campanha eleitoral, além dos dirigentes partidários e o candidato, respectivamente.

Denise Schlickmann e Heloísa Lübke afirmam que o elemento subjetivo do tipo proposto é o dolo, eis que não há previsão da forma culposa do crime. A ação involuntária, o esquecimento ou a imperícia, para as autoras, não é punível ${ }^{179}$.

Newton Lins ressalta que pode haver uma confusão entre o crime de movimentação de recursos de modo paralelo e o de omissão de informações. O autor explica, porém, que o crime de "caixa dois" é assemelhado com o crime comum de sonegação fiscal ${ }^{180}$, enquanto a infração de omissão assemelha-se com a conduta já prevista no art. 350 do CE.

\footnotetext{
177 “Art. 293. Além das consequiências previstas no art. 91 do Código Penal, são também efeitos da condenação:

I - a suspensão de atividade de diretório, no caso do art. 296, § 2o;

II - a cassação do registro de candidatura, no caso do art. 313;

III - a perda do mandato eletivo, nos casos dos crimes previstos nos arts. 319, 320, 324, 325, 330, 334, 338 e 339 e nos casos de condenação, por qualquer outro crime, à pena aplicada superior a 4 (quatro) anos".

178 “Art. 340. Omitir, na prestação de contas, recurso ou valor relativo à receita ou despesa de partido político ou de campanha eleitoral, ou outra informação exigida pela Justiça Eleitoral:

Pena - reclusão, de 1 (um) a 4 (quatro) anos, e multa".

${ }^{179}$ Cf. Denise Goulart Schlickmann e Heloísa Helena Bastos Silva Lübke. "Financiamento de campanhas eleitorais: avaliação das propostas apresentadas pelo Tribunal Superior Eleitoral ao Congresso Nacional", p. 137.

${ }_{180}$ Cf. Newton Lins, "Quando o caixa dois é o número um”. Consulex: Revista Jurídica, ano X, n. 216, jan. 2006, p. 32.
} 
Por fim, há também a proposta da tipificação do recebimento de recursos de fontes vedadas (art. 345 proposto) ${ }^{181}$. O texto do artigo proposto remete ao artigo 31 da LPP, que trata das fontes de recursos vedadas aos partidos. Porém, este artigo inclui como fonte vedada as entidades de classe e as entidades sindicais, enquanto que o art. 345 proposto não as inclui como objeto de eventual punição, sem haver qualquer justificativa para tanto.

Ressalte-se que o art. 24 da LE, que trata das fontes de recursos vedadas às campanhas eleitorais, tem rol de fontes vedadas bem mais extenso, fato este que cria a interpretação de que as fontes previstas tanto no art. 31 da LPP como no art. 24 da LE, mas que não constam no rol do artigo proposto não enseja a pena de reclusão prevista in fine. Se a condenação foi superior a quatro anos de reclusão, o candidato tem seu mandato eletivo cassado, conforme determinação do art. 293, inciso III proposto.

A proposta elaborada pela Comissão instituída pelo TSE defende também mudanças na Lei Complementar n. 64/90 - a Lei das Inelegibilidades. Serão analisadas as mudanças proposta que guardem relação com o financiamento da política.

A norma vigente define que o político será considerado inelegível para a eleição em que estiver concorrendo ou que tenha sido diplomado, além das que ocorrerem nos três anos seguintes caso tenha contra si representação eleitoral por abuso do poder econômico ou político julgada procedente e transitada em julgado (art. $1^{\circ}$, inciso I, alínea "d" da LI). Propõe a Comissão do TSE duas mudanças: (i) aumento no prazo de duração da inelegibilidade do candidato condenado: o postulante infrator será inelegível são só por três anos, mas por quatro anos; e (ii) desnecessidade do trânsito em julgado para a aplicação da sanção, que fica condicionada somente à publicação da decisão de segunda instância ou única, se for o caso ${ }^{182}$.

\footnotetext{
181 “Art. 345. Receber, direta ou indiretamente, sob qualquer forma ou pretexto, recurso, contribuição ou auxílio pecuniário ou estimável em dinheiro, inclusive através de publicidade de qualquer espécie, procedente de:

I - entidade ou governo estrangeiro;

II - autoridade ou órgão público, ressalvadas as dotações legais;

III - autarquia, empresa pública ou concessionária de serviço público, sociedade de economia mista e fundação instituída em virtude de lei e para cujos recursos concorram órgãos ou entidades governamentais.

Parágrafo único. Consideram-se recurso as hipóteses previstas no art. 305, § 2o, deste código.

Pena - Reclusão, de 2 (dois) a 6 (seis) anos, e multa”.

182 “Art. $1^{\circ}[\ldots]$
} 
O motivo é simples: se um candidato a prefeito na eleição de 2008, por exemplo, for condenado em representação por abuso de poder econômico transitada em julgado, é considerado inelegível para aquela eleição municipal e para os próximos três anos, e nesse período só ocorrerá uma eleição geral (de caráter estadual ou nacional, em 2010). Passados esses três anos, o candidato condenado poderá postular novamente os votos do eleitorado de seu município na eleição para prefeito seguinte (em 2012). Com a pena aumentada para quatro anos, neste caso hipotético, o condenado somente poderá ser candidato a algo na eleição geral de 2014. Corrobora com esta opinião Joel Cândido, afirmando inclusive que tal prazo deveria ser de cinco anos ${ }^{183}$.

A outra importante mudança diz respeito ao momento da aplicação da sanção determinada pela LI. Enquanto a legislação vigente define que o momento para a aplicação da sanção se dá somente com o trânsito em julgado da decisão, a Comissão propôs a aplicação assim que a segunda ou única instância proferir sua decisão, em uma tentativa de prevenir "manobras protelatórias ou metajurídicas que findam por obstaculizar a eficácia das normas" ${ }^{184}$. As mesmas sugestões de mudança legislativa da alínea "d" são dispostas na alínea "h", que trata da inelegibilidade aos detentores de cargo na administração pública direta e indireta, incluídas as fundações públicas, que beneficiarem a si ou a terceiros, pelo abuso do poder econômico.

Por fim, o projeto trata da alteração do inciso XIV do art. 22 da LI, que dispõe sobre o rito da ação de investigação judicial eleitoral (AIJE). Segundo a proposta, ao ser condenado em segunda ou única instância, o candidato perde automaticamente o registro ou o diploma (a legislação vigente determina a existência do trânsito em julgado), além do aumento d0 período de inelegibilidade de três para seis anos.

$\mathrm{I}-[\ldots]$

d) os que tenham contra sua pessoa representação julgada procedente pela Justiça Eleitoral, em decisão de segunda ou única instância, em processo de apuração de abuso do poder econômico ou político, para a eleição na qual concorrem ou tenham sido diplomados e para as que se realizarem até quatro anos seguintes à decisão".

${ }^{183}$ Cf. Joel J. Cândido, Inelegibilidades no direito brasileiro. Bauru: Edipro, 2.ed. rev., atual. e ampl., 2003 , p. 369.

${ }^{184}$ Anexo II - Anteprojeto de lei complementar que altera a Lei Complementar no 64, de 1990”, in Brasil. Tribunal Superior Eleitoral. Reforma eleitoral: delitos eleitorais, prestação de contas (partidos e candidatos), propostas do TSE. - Brasília: SDI, 2005, p. 94. 
O projeto da Comissão de Notáveis do TSE também propõe mudanças nas regras das prestações de contas de campanhas contidas na LE, em especial em seu art. 30. Para garantir maior celeridade no julgamento das prestações e "dar concretude (...) ao disposto no art. $14, \S 90$, da Constituição ${ }^{185}$, , o projeto propõe que somente o julgamento das prestações dos candidatos eleitos deve ser realizado em até oito dias antes da diplomação (alteração do art. 30, § $1^{\circ}$ então vigente), pois indubitavelmente há mais urgência na análise das prestações dos candidatos vencedores. Esta alteração, no entanto, já consta da Lei n. 9.504/97, por conta da edição da Lei n. 11.300, de março de 2006, lei esta a ser tratada especificamente no próximo capítulo do presente trabalho.

A determinação legal de priorizar o julgamento das prestações de contas dos candidatos eleitos é elogiada por Denise Goulart Schlickmann e Heloísa Helena Bastos Silva Lübke, pois dá à Justiça Eleitoral a possibilidade de dedicar-se mais profundamente ao exame dessas contas, mesmo que as prestações dos suplentes sejam julgadas depois, já que a Justiça Eleitoral não tem condições de prestar o serviço jurisdicional adequadamente se tiver que julgar todas as contas antes da diplomação ${ }^{186}$.

Prevê também o projeto a possibilidade de reabertura da análise da prestação de contas na Justiça Eleitoral em um prazo de até quatro anos, sendo legitimados para tanto o Ministério Público, os partidos políticos e o próprio candidato, no caso de retificação (art. 30, § $5^{\circ}$ proposto). Esta disposição vai de encontro à norma do art. 32 da LE, que prevê a obrigatoriedade dos partidos e dos candidatos em manter a documentação referente às prestações de contas somente por 180 dias após a diplomação.

Assim sendo, o projeto prevê que o novo prazo é de quatro anos, ou seja, até o final do mandato do candidato eleito. Este prazo é mais razoável, pois apenas 180 dias é um termo muito curto para a manutenção desta documentação tão importante, eis que por muitas vezes as denúncias a respeito de irregularidades na administração financeira de uma campanha eleitoral surgem meses ou até anos depois. Ademais, conforme rememoram Denise Schlickmann e Heloísa Lübke, o compartilhamento de dados com a

\footnotetext{
185 "Anexo III - Anteprojeto de lei que altera a Lei $\mathrm{n}^{\circ}$ 9.504, de 1997", in Brasil. Tribunal Superior Eleitoral. Reforma eleitoral: delitos eleitorais, prestação de contas (partidos e candidatos), propostas do TSE. - Brasília: SDI, 2005, p. 101.

${ }^{186}$ Cf. Denise Goulart Schlickmann e Heloísa Helena Bastos Silva Lübke. "Financiamento de campanhas eleitorais: avaliação das propostas apresentadas pelo Tribunal Superior Eleitoral ao Congresso Nacional”, p. 141.
} 
Receita Federal ou o monitoramento de operações financeiras feito pelo Banco Central pode gerar novas informações a respeito de irregularidades nas campanhas ${ }^{187}$.

Em consonância com esses aspectos apresentados, o projeto prevê a ocorrência do trânsito em julgado das prestações de contas também somente após quatro anos (ou seja, ao final dos mandatos eletivos). A possibilidade de retificações nas prestações de contas só é válida no caso de contas aprovadas com ressalvas, já que o inciso II do $\S 6^{\circ}$ do art. 30 proposto não permite a retificação no caso de a prestação de contas ter sido rejeitada pela Justiça Eleitoral.

A grande novidade do projeto é o art. $30, \S 7^{\circ}$ proposto $^{188}$ : no caso de rejeição da prestação de contas por existência de conduta dolosa, o candidato eleito não poderá ser diplomado. Se já estiver diplomado, perderá o mandato.

Assim sendo, o projeto não prevê somente a inelegibilidade do candidato após processo de apuração de abuso do poder econômico transitado em julgado ou o mero pagamento de multa no caso de infração grave ao sistema de financiamento das campanhas eleitorais, mas sim a maior pena de caráter político existente para um candidato já eleito - a impossibilidade de diplomar-se, não podendo assumir o mandato para o qual foi eleito - ou para um político que já está no curso de seu de mandato: a perda do mesmo, se houver irregularidades graves na prestação de contas.

É interessante notar que não há menção para as hipóteses de conduta dolosa que possa ensejar uma possível rejeição de contas. Supõe-se, portanto, que qualquer falha de caráter mais grave, como o recebimento de recursos de origem vedada, atos que caracterizem abuso do poder econômico ou até o cometimento de crime eleitoral no momento da prestação de contas pode acarretar a perda do mandato ou a nãodiplomação.

\footnotetext{
${ }^{187}$ Cf. Denise Goulart Schlickmann e Heloísa Helena Bastos Silva Lübke. "Financiamento de campanhas eleitorais: avaliação das propostas apresentadas pelo Tribunal Superior Eleitoral ao Congresso Nacional", p. 142.

188 “Art. 30. [...]

§ 7o A rejeição de contas de campanha por conduta dolosa, em segunda ou única instância, impede a diplomação ou implica a perda de mandato do candidato eleito, sem prejuízo, se for o caso, de representação à autoridade fiscal".
} 
Denise Schlickmann e Heloísa Lübke afirmam que há uma contradição do projeto como ora proposto: a aplicação imediata da cassação dos registros ou do diploma por conduta dolosa na prestação de contas confronta a disposição de que as prestações de contas só têm seu trânsito em julgado ao final do mandato do candidato eleito $^{189}$.

Ou seja, há uma afronta aos princípios constitucionais da igualdade e do devido processo legal: se houver decisão judicial para a punição do candidato, aplica-se imediatamente. Mas se as contas forem aprovadas, não gera efeitos de coisa julgada definitivamente, pois pode ocorrer fato jurídico superveniente, ignorando-se assim a coisa julgada.

Por fim, o projeto prevê alterações nas leis que tratam do imposto de renda sobre a pessoa jurídica e sobre a pessoa física, para a criação de benefícios fiscais para os doadores de recursos para as campanhas eleitorais que as financiam licitamente.

No caso das pessoas jurídicas doadoras, o projeto introduz o inciso IV no $§ 20$ do art. 13 da Lei no 9.249, de 28 de dezembro de $1995^{190}$. As doações das pessoas jurídicas, segundo o projeto, estariam limitadas a $2 \%$ de seu lucro operacional, devendo elas ser feitas mediante cheque nominativo a ser depositado em contas específicas, contas estas abertas conforme instrução a ser expedida pelo TSE ou a elas transferidas por meio eletrônico ${ }^{191}$.

${ }^{189}$ Cf. Denise Goulart Schlickmann e Heloísa Helena Bastos Silva Lübke. "Financiamento de campanhas eleitorais: avaliação das propostas apresentadas pelo Tribunal Superior Eleitoral ao Congresso Nacional", p. 143.

190 “Art. 13. [...]

$\S 20[\ldots]$

IV - destinadas a partidos políticos ou a candidatos a cargos eletivos, em campanha eleitoral, até o limite de dois por cento do lucro operacional da pessoa jurídica, antes de computada a correspondente dedução, observado que as doações de que trata este inciso:

a) somente poderão ser feitas em cheque nominativo ou transferência bancária;

b) deverão ser depositadas obrigatoriamente em contas bancárias específicas, abertas em conformidade com instruções expedidas pelo Tribunal Superior Eleitoral;

c) deverão obedecer às limitações estabelecidas no art. 24 da Lei n. 9.504, de 30 de setembro de 1997;

d) somadas às doações a que se refere o inciso III também não poderão ultrapassar o limite de dois por cento do lucro operacional da pessoa jurídica, antes de computadas as correspondentes deduções.

§ 3o Caso as doações e contribuições a partidos políticos ou a candidatos a cargos eletivos, em campanha eleitoral, efetivadas na forma do art. $81, \S 1$ o, da Lei n. 9.504, de 1997, ultrapassem o limite fixado no inciso IV do $§ 20$ deverão ser consideradas indedutíveis para fins do disposto no caput deste artigo."

${ }^{191}$ Cf. "Anexo IV - Anteprojeto de lei que dispõe sobre incentivos fiscais para doações a partidos políticos e candidatos", in Reforma eleitoral: delitos eleitorais, prestação de contas (partidos $e$ candidatos), propostas do TSE. - Brasília: SDI, 2005, p. 105. 
O projeto teve a preocupação de não contrariar a Lei de Responsabilidade Fiscal (Lei Complementar n. 101/2000), ao determinar que as doações aos partidos ou às campanhas, somadas às doações para entidades de assistência social (art. 13, § $2^{\circ}$ da Lei n. 9.249/95) não poderão ultrapassar os limites fixados para efeito de dedutibilidade, determinação essa que denota a inexistência de crescimento de renúncia fiscal por parte do Tesouro Nacional. No caso de a doação ultrapassar o limite previsto no art. $81, \S 1^{\circ}$ da LE (limite de $2 \%$ do faturamento bruto da empresa no ano anterior à eleição), a parcela a maior será tratada como doação indedutível.

No que tange às pessoas físicas, os benefícios físcais seriam trazidos ao ordenamento jurídico por meio do ingresso do inciso VII no art. 12 da Lei no 9.250/95 ${ }^{192}$, havendo observância, no entanto, ao limite existente para incentivos fiscais para as pessoas físicas (6\% do valor do imposto devido), conforme determina o texto proposto para o art. 22 da Lei n. 9.532/97 ${ }^{193}$. Também neste caso não há um aumento da renúncia fiscal, diante da proibição do art. 14 da Lei de Responsabilidade Fiscal.

Estudado projeto de lei do Senado n. 382/2005, apresentado pelo senador Renan Calheiros à Casa e elaborado pela Comissão de Notáveis do TSE, passar-se-á à análise do projeto de lei de reforma política enviados ao Congresso Nacional pela Secretaria de Assuntos Legislativos do Ministério da Justiça em fevereiro de 2009.

\subsubsection{Proposta de Reforma Política do Governo Federal (Secretaria de Assuntos} $\underline{\text { Legislativos do Ministério da Justiça) }}$

Ante a aparente unanimidade na sociedade brasileira sobre a necessidade de mudanças legislativas no sistema político-eleitoral e após a apresentação de vários projetos por parte do Congresso Nacional e também do poder Judiciário, o poder Executivo, por meio da Secretaria de Assuntos Legislativos do Ministério da Justiça, apresentou sua proposta de reforma política, que foi antecedida por uma consulta

192 “Art. 12. [...]

VII - as doações a partidos políticos ou a candidatos a cargos eletivos, em campanha eleitoral, observado o disposto no art. 23, § 1o, inciso I, da Lei no 9.504, de 30 de setembro de 1997."

193 "Art. 22. A soma das deduções a que se referem os incisos I a III e VII da Lei no 9.250, de 1995, fica limitada a seis por cento do valor do imposto devido" 
pública durante o período de 27 de agosto a 15 de novembro de 2008, à Câmara dos Deputados em fevereiro de 2009.

A proposta do governo federal se caracteriza por abranger diversos assuntos considerados cruciais no cenário político brasileiro. Cada assunto, no entanto, mereceu um projeto específico, quais sejam:

a) Projeto de Lei n. 4.636/09 ${ }^{194}$, que sugere a adoção do sistema de lista fechada nas eleições proporcionais;

b) Projeto de Lei n. $4.635 / 09^{195}$; que dispõe sobre a fidelidade partidária, criando um período em que a troca do partido é permitida, além de novas possíveis justificativas para a mudança de legenda;

c) Projeto de Lei n. 4.637/09 ${ }^{196}$, que trata das coligações nas eleições proporcionais, coibindo a prática de constituições de coligações com o único objetivo de conferir maior tempo de propaganda eleitoral ao candidato da coligação nas eleições majoritárias;

d) Projeto de Lei n. 4.633/09 ${ }^{197}$, que sugere alteração do art. 41-A da LE, tipificando criminalmente a captação ilícita de voto;

e) Projeto de Lei Complementar n. 446/09 ${ }^{198}$, que altera a LI, dispondo sobre a inelegibilidade dos candidatos condenados por abuso do poder econômico ou político, entre outros;

f) Proposta de Emenda à Constituição n. $322 / 09^{199}$, que instituí no texto constitucional a cláusula de desempenho (ou de barreira); e

g) Projeto de Lei n. 4.634/09 200 , que sugere a adoção do sistema exclusivamente público para o financiamento de campanhas eleitorais.

\footnotetext{
${ }^{194}$ Disponível em: <http://www.camara.gov.br/sileg/integras/632495.pdf>. Último acesso em 20.12.2009. O projeto foi apensado ao PL n. 2.887/2000, que está pronto para ser incluído na pauta da Comissão de Constituição, Justiça e Cidadania (CCJC) da Câmara dos Deputados desde 25.08.2009.

${ }^{195}$ Disponível em: <http://www.camara.gov.br/sileg/integras/632492.pdf>. Último acesso em 20.12.2009. A proposta foi apensada ao PL n. 2.211/07, que aguarda novo parecer do deputado federal Gerson Peres (PP-Pará) desde 13.11.2009.

${ }^{196}$ Disponível em: <http://www.camara.gov.br/sileg/integras/632497.pdf>. Último acesso em 20.12.2009. O projeto está pronto para entrar na pauta da CCJC da Câmara desde 16.06.2009.

${ }^{197}$ Disponível em: <http://www.camara.gov.br/sileg/integras/632496.pdf>. Último acesso em 20.12.2009. A proposta foi apensada ao PL n. 2.870/08. Em 24.11.2009, a Mesa da Câmara dos Deputados determinou seu arquivamento, eis que sua análise ficou prejudica pela vigência da Lei n. 12.034/09.

${ }^{198}$ Disponível em: <http://www.camara.gov.br/sileg/integras/632485.pdf>. Último acesso em 20.12.2009. O projeto foi apensado ao PLP n. 168/1993, este também de autoria do poder Executivo, e está pronto para votação no Plenário desde 14.11.2001.

${ }^{199}$ Disponível em: <http://www.camara.gov.br/sileg/integras/632479.pdf>. Último acesso em 20.12.2009. A proposta aguarda o parecer de seu relator, deputado João Almeida (PSDB-Bahia) e membro da CCJC desde 25.03.2009.
} 
O PL n. 4.636/09 não tem nenhuma diferença substancial em comparação ao PL n. 2.679/03 estudado no item 2.2.1 anterior. As justificativas e os objetivos ${ }^{201}$, inclusive, são bastante parecidos: fortalecimento dos partidos, facilitação do controle dos gastos de campanha, fim da competição intrapartidária entre os candidatos.

Já o PL n. 4.637/09 propõe a extinção das coligações nas eleições proporcionais diante dos pontos já estudados no item 2.1.1.1 deste trabalho, que é principalmente a possibilidade de o voto de um eleitor beneficiar outro partido coligado (sem que o eleitor saiba de tal mecanismo legal).

Há também a preocupação com o fato de se formar coligações nas eleições majoritárias sem qualquer relação com a ideologia das legendas coligadas, importando apenas o aumento do tempo de propaganda eleitoral na televisão e no rádio para a formação da aliança. Assim, o projeto propõe a mudança do art. $47, \S 2^{\circ}$, incisos I e II, diminuindo o tempo de propaganda eleitoral dos partidos que não tem representação na Câmara dos Deputados, além de incluir o $\S 7^{\circ}$, que determina que para os efeitos de distribuição de tempo na propaganda eleitoral, só será levado em conta o tempo de direito do partido com maior representação na Câmara (se houver coligação), determinação esta que tira o poder de barganha dos partidos menores em negociações para as coligações.

A PEC n. 322/09 traz a proposta do poder Executivo para uma cláusula de desempenho eleitoral no texto constitucional. Contém tal proposta a inclusão do $\S 5^{\circ}$ no art. 17 da CRFB, que define que somente os partidos que atingirem ao menos $1 \%$ dos votos válidos para a Câmara dos Deputados - sendo estes votos distribuídos em pelo menos um terço dos Estados e com o mínimo de 0,5\% dos votos em cada um deles poderão ter seus candidatos eleitos o direito de exercer mandatos na Câmara dos Deputados, nas Assembléias Legislativas ou na Câmara Distrital.

\footnotetext{
${ }^{200}$ Disponível em: <http://www.camara.gov.br/sileg/integras/632489.pdf>. Último acesso em 20.12.2009. O projeto foi apensado ao PL n. 1.538/07, e aguarda parecer de seu relator, deputado Ricardo Berzoini (PT- São Paulo) e membro da CFT - Comissão de Finanças e Tributação desde 22.08.2007.

${ }^{201}$ As propostas originais, suas justificativas e os objetivos de seus elaboradores na Secretaria de Assuntos Legislativos do Ministério da Justiça estão disponíveis em: <http://www.mj.gov.br/data/Pages/MJD7695499CITEMID55498E7C67BF49BA9B9D3CAF311B41F4P TBRIE.htm>.Último acesso em 15.01.2009.
} 
A regra proposta parece menos rígida que a prevista no art. 13 da LPP e considerada inconstitucional pelo STF, pois esta previa a votação de 5\%. Porém, na regra legal, se o partido não obtivesse tal índice de votação, ele perderia o direito ao funcionamento parlamentar, ou seja, os seus candidatos eleitos exerceriam seus respectivos mandatos, porém sem algumas das prerrogativas definidas nos Regimentos Internos de cada Casa Legislativa. Esta proposta, ao contrário, prevê que o partido que não superar a cláusula de desempenho eleitoral perderá todas as cadeiras conquistadas nas eleições para os cargos proporcionais.

O PL n. 4.635/09, que dispõe sobre a fidelidade partidária propõe a mudança de alguns dispositivos da LPP, em consonância com a já aqui debatida Resolução do TSE n. 22.610/07. Sua novidade é a "janela" prevista no art. 26, inciso IV da LPP proposto, que dá a chance ao político em exercício do mandato mudar de partido nas vésperas do início do período eleitoral (prevê tal inciso o prazo de 10 de maio até o prazo para início das convenções partidárias).

O PL n. 4.633/09, que trata da captação ilícita de sufrágio, prevê nova tipificação (a proposta contém sugestão para o texto do art. 41-B da LE): a compra de votos feita mediante violência. Para os dois tipos de captação ilícita de sufrágio, tal proposta também prevê multa ao candidato que pode variar se $\mathrm{R} \$ 10.000,00$ (dez mil reais) a $\mathrm{R} \$$ 100.000,00 (cem mil reais), sem prejuízo das sanções penais cabíveis e da decretação de perda do mandato.

A PLP n. 446/09 trata de mudanças na LI, alterações estas que guardam relação com o sistema normativo do financiamento da política no Brasil. A proposta encaminhada pelo poder Executivo contém alterações nas alíneas "d", "e" e "h" do inciso I do art. $1^{\circ}$ da LI, sendo as alíneas "d" e " $h$ " as que prevêem a punição de inelegibilidade por três anos àqueles que forem condenados por abuso de poder econômico. A PLP em comento, no entanto, não tem qualquer alteração no período de inelegibilidade hoje vigente (ao contrário do Projeto elaborado pela Comissão de Notáveis do TSE, que defende o aumento do prazo para quatro anos, conforme já estudado no item 2.2.2), mas a desnecessidade da ocorrência do trânsito em julgado para 
a aplicação da punição de inelegibilidade se houver decisão colegiada (havendo somente a decisão da primeira instância, deve-se esperar o trânsito em julgado).

Por fim, o PL n. 4.634/09 prevê a adoção do sistema de financiamento da atividade política de caráter exclusivamente público, sendo vedadas doações privadas de qualquer origem aos partidos políticos (alteração do art. 31 da LPP ${ }^{202}$ ) e às campanhas eleitorais (revogação dos arts. 23 e 81 da LE).

Ante o fato de o financiamento ser exclusivamente público, prevê o projeto que a responsabilidade sobre a arrecadação e a aplicação dos recursos na campanha será do partido, e não do candidato, alterando assim o art. 17 da LE ${ }^{203}$. Em comparação ao PL n. 2.679/2003 analisado no item 2.2.1, percebe-se que o projeto de autoria do poder Executivo prevê maiores recursos aos partidos menores (eis que garante 19\% aos partidos com representação na Câmara, ao contrário do projeto da Comissão Especial da Câmara, que determina somente $14 \%$ para estas legendas).

Pode-se afirmar que há um paradoxo nesta proposta da Secretaria de Assuntos Legislativos do Ministério da Justiça (SAL-MJ), eis que os outros projetos acima estudados prevêem mecanismos que enfraquecem as legendas maiores, como a adoção da cláusula de desempenho ou o fim das coligações nas eleições proporcionais, enquanto que os mesmos proponentes garantem mais recursos às campanhas eleitorais destes partidos menores.

\footnotetext{
${ }^{202}$ Texto proposto: “Art. 31. É vedado ao partido receber, direta ou indiretamente, sob qualquer forma ou pretexto, contribuição ou auxílio pecuniário ou estimável em dinheiro, inclusive através de publicidade de qualquer espécie, procedente de pessoa física ou jurídica, de direito público ou privado, nacional ou estrangeira."

${ }^{203}$ Texto proposto: “Art. 17. As despesas da campanha eleitoral serão realizadas sob a responsabilidade dos partidos e financiadas na forma desta Lei.

$\S 1^{\circ}$ Em ano eleitoral, a lei orçamentária incluirá dotação, em rubrica própria, consignada ao Tribunal Superior Eleitoral, no anexo referente ao Poder Judiciário, destinada ao financiamento de campanhas eleitorais, tendo por referência o eleitorado existente em 30 de abril do ano da elaboração da lei orçamentária.

$\S 2^{\circ} \mathrm{O}$ Tribunal Superior Eleitoral fará a distribuição dos recursos aos órgãos de direção nacional dos partidos políticos, obedecidos os seguintes critérios:

I - um por cento, dividido igualitariamente entre todos os partidos com estatutos registrados no Tribunal Superior Eleitoral;

II - dezenove por cento, divididos igualitariamente entre os partidos com representação na Câmara dos Deputados;

III - oitenta por cento, divididos entre os partidos, proporcionalmente ao número de eleitos na última eleição para a Câmara dos Deputados."
} 
Nos textos dos arts. 20 e 22 da LE, a proposta da SAL-MJ prevê a retirada do termo "candidato", eis que a administração dos recursos passaria a ser de responsabilidade exclusiva do partido. Propõe-se também a mudança do texto do art. 24 da $\mathrm{LE}^{204}$, cujo texto vigente define as fontes vedadas. Como a proposta traz a adoção do financiamento exclusivamente de origem pública, não há mais sentido em se falar pormenorizadamente de fontes vedadas, eis que só seria permitido administrar recursos provenientes do Tesouro Nacional com este propósito.

Quanto à prestação de contas, a responsabilidade pela sua feitura e pela sua apresentação à Justiça Eleitoral é do comitê financeiro partidário, em alteração ao art. 28 da $\mathrm{LE}^{205}$. O texto ora vigente determina responsabilizações diferenciadas em caso de eleição majoritária ou proporcional.

Já o art. 29 proposto resume as funções do Comitê Financeiro Partidário no momento de prestação de contas à Justiça Eleitoral, sendo retirado qualquer tipo de função ou responsabilidade do candidato neste tema. $\mathrm{O}$ art. 30 também prevê que somente o Comitê Financeiro poderá fornecer informações à Justiça Eleitoral referentes a possíveis irregularidades nas prestações de contas, sendo também excluída a responsabilidade do candidato.

Por fim, o art. 32 proposto mantém o prazo de 180 dias para a manutenção da documentação relativa à prestação de contas (ressalte-se que conforme item anterior do presente capítulo, a Comissão de Notáveis propôs um prazo de quatro anos, pelos motivos expostos no item 2.2.2). Porém, o projeto da SAL-MJ prevê novamente que a responsabilidade por tais documentos é do partido, e não do candidato.

\footnotetext{
${ }^{204}$ Texto proposto: "Art. 24. É vedado, a partido e candidato, receber direta ou indiretamente doação em dinheiro ou estimável em dinheiro, inclusive por meio de publicidade de qualquer espécie, procedente de pessoa física ou jurídica, de direito público ou privado, nacional ou estrangeira."

${ }^{205}$ Texto proposto: "Art. 28. As prestações de contas das campanhas eleitorais serão feitas por intermédio dos comitês financeiros, devendo ser acompanhadas dos extratos das contas bancárias referentes à movimentação dos recursos financeiros utilizados.

$\S 1^{\circ}$. A Justiça Eleitoral poderá expedir atos complementares para disciplinar a prestação de contas das campanhas eleitorais.

$\S 20$ Os partidos políticos são obrigados, durante a campanha eleitoral, a divulgar, pela rede mundial de computadores (internet), nos dias 6 de agosto e 6 de setembro, relatório discriminando os recursos em dinheiro ou estimáveis em dinheiro que tenham recebido para financiamento da campanha eleitoral, e os gastos que realizarem, em sítio criado pela Justiça Eleitoral para esse fim.”
} 
Há diversas observações a serem feitas em referência a este projeto do poder Executivo no que toca à adoção do sistema de financiamento da atividade política exclusivamente público.

A primeira delas é que não há no projeto da SAL-MJ nenhum critério para a divisão dos recursos no momento em que eles são depositados nas contas correntes dos partidos políticos. Não há, por exemplo, nenhuma previsão referente à qual campanha receberá recursos.

Pode-se até alegar que o partido tem o dever de repassar os recursos financeiros para todas as campanhas de seus candidatos, mas se isso for verdade, quanto cada uma delas receberá? As campanhas majoritárias, por serem mais caras e de maior destaque na corrida eleitoral, devem receber mais dinheiro? E se o partido entender que somente as campanhas que tiverem algum tipo de chance de vitória devem receber recursos? Os diretórios regionais e municipais localizados em lugares mais populosos devem receber mais dinheiro que os outros? Ou o partido deve ter outro tipo de critério, como injetar mais recursos nos locais em que é mais fraco, dificultando o trabalho dos seus adversários?

Diante desta omissão, pode haver também o favorecimento de alguns diretórios regionais ou municipais, se for o caso, pelos mais variados critérios como, por exemplo, a importância da vitória em um estado, ou a necessidade da eleição de importante liderança partidária na eleição para deputado federal. Abre-se a possibilidade de haver a hipertrofia exacerbada da burocracia partidária e do fortalecimento em demasia do poder dos líderes partidários, que seriam em tese os responsáveis pela distribuição dos recursos de campanha assim que depositados na conta do partido pelo Tesouro Nacional.

Ao contrário do PL n. 2.679/03, também não há previsão na proposta elaborada pela SAL-MJ do prazo máximo para o TSE distribuir os recursos, o que pode prejudicar o planejamento administrativo dos partidos no caso de atraso.

Analisando conjuntamente todos os aspectos merecedores de mudança legislativa na visão dos membros da SAL-MJ, nota-se que a adoção do sistema de 
financiamento exclusivamente público como ora proposto é viável apenas se aprovado conjuntamente, no mínimo, o PL n. 4.636/09, que trata da adoção do sistema de lista fechada nas eleições proporcionais.

O cenário das eleições proporcionais existente hoje no Brasil é o de candidaturas individuais (conforme item 2.1.1.2), além de haver disputas entre candidatos do mesmo partido nestas eleições. O sistema de lista aberta vigente proporciona, destarte, infraestruturas de campanhas individuais praticamente independentes das legendas, acarretando arrecadação e aplicação de recursos também independentes nas campanhas eleitorais.

Há, portanto, absoluta incompatibilidade entre o sistema de financiamento exclusivamente público com a existência de campanhas individuais, ainda mais sendo todos os atos de administração financeira sob responsabilidade do partido, e não mais do candidato, conforme proposição elaborada pela SAL-MJ.

Fernando Neves da Silva corrobora com este entendimento, afirmando que nas eleições proporcionais, seria difícil para os partidos decidirem quais critérios seriam adotados para a distribuição dos recursos (valor igual; mais dinheiro para os candidatos "puxadores de votos"; por exemplo), vez que as eleições em lista aberta acarretam em existência de candidaturas individuais ${ }^{206}$.

Ademais, mesmo que adotada a proposta de lista fechada conjuntamente com o financiamento exclusivamente público, não há sentido em responsabilizar-se somente o partido caso haja irregularidades nas eleições majoritárias: o candidato ao poder Executivo e ao Senado tem, de qualquer modo, campanha individualizada

\footnotetext{
${ }^{206}$ Cf. Fernando Neves da Silva, "Financiamento de campanha política e corrupção eleitoral”, p. 37.
} 


\subsubsection{Financiamento da Política de caráter Público x Financiamento da Política de caráter Privado: vantagens e desvantagens}

A discussão entre as vantagens e as desvantagens dos sistemas de financiamento da política existentes em outros países tem sido a tônica não só entre os analistas do sistema brasileiro, mas também principalmente entre a classe política brasileira ${ }^{207}$.

Entre os três projetos estudados anteriormente, dois deles defendem o sistema de financiamento das campanhas eleitorais exclusivamente público como a melhor forma de dirimir os problemas causados pela atual legislação.

A adoção de um sistema exclusivamente público de financiamento da política no Brasil ganhou inclusive status de programa de defesa dos direitos humanos. O Programa Nacional de Direitos Humanos lançado pela Secretaria Especial de Direitos Humanos da Presidência da República (SEDH/PR) sob o Decreto n. 7.037, de 21.12.2009, determina, dentre outros temas, do apoio aos projetos legislativos de adoção do sistema público de financiamento de campanhas como uma de suas diretrizes para garantir uma maior "participação igualitária e acessível na vida política"208.

O financiamento público, conforme visto no item 2.2 no caso brasileiro, é apontado como a solução para as questões presentes no cenário político brasileiro conseqüentemente, o financiamento privado atualmente vigente é taxado como principal problema do panorama político brasileiro.

Outros estudiosos, conforme se verá adiante, afirmam que as vantagens da adoção do sistema exclusivamente público no Brasil apontadas pela doutrina não justificam uma mudança tal radical, já que o sistema misto vigente atualmente também apresenta grandes virtudes, devendo ele ser melhor aperfeiçoado, e não extinto.

\footnotetext{
207 Renato Janine Ribeiro afirma que dentre os diversos aspectos abrangidos sob o tema da reforma política no Brasil, o voto obrigatório e o financiamento das campanhas eleitorais sejam os únicos em que haja forte polarização não só entre os políticos, mas também na sociedade (Cf. Renato Janine Ribeiro, "Financiamento de campanha (público versus privado)", in Leonardo Avritzer e Fátima Anastasia (orgs.), Reforma política no Brasil, Belo Horizonte: Editora UFMG, 2006, p. 77).

${ }^{208}$ Programa Nacional de Direitos Humanos (PNDH-3, Decreto n. 7.037, de 21.12.2009; Secretaria Especial de Direitos Humanos da Presidência da República), disponível em <http://www.mj.gov.br/sedh/pndh3/pndh3.pdf>. Último acesso em 10.1.2009.
} 
Para um melhor entendimento do debate doutrinário entre as vantagens e desvantagens do sistema de financiamento de caráter público ou de caráter privado, é necessário apontar quais são esses elementos, vantajosos ou não.

Os partidos políticos começaram a ganhar força institucional e legislativa principalmente no início do século XX. Muitas das Constituições européias, principalmente aquelas redigidas após o fim da II Guerra Mundial, reconheceram a relevância que os partidos obtiveram ao longo dos anos no cenário social, por meio de disposições específicas no texto constitucional sobre a importância das legendas e dos princípios a serem seguidos pelas mesmas, como na Lei Fundamental da República Federal da Alemanha de $1949^{209}$, na Constituição francesa de $1958^{210}$, na Constituição Italiana de $1949^{211}$ e no texto constitucional português de $1976^{212}$.

Andrés Serra Rojas corrobora com a opinião de que os partidos são entes fundamentais do sistema democrático, classificando-os de "indispensáveis ao processo político", principalmente pela função de "mobilizar os eleitores"213. Rodrigo Borja afirma no mesmo sentido, conforme trecho adiante:

Os partidos são os pilares do sistema democrático. (...) Intermediários entre o governo e a sociedade, estão chamados a recolher, enriquecer e processar as aspirações da comunidade. ${ }^{214}$

\footnotetext{
209 "Artigo 21 (Partidos)

(1) Os partidos colaboram na formação política do povo. A sua fundação é livre. a sua organização interna tem de corresponder aos princípios democráticos. Eles têm de prestar contas publicamente sobre a origem e a aplicação de seus recursos, bem como sobre seu patrimônio".

${ }^{210 ، A r t i g o ~ 4 . ~ O s ~ p a r t i d o s ~ e ~ o s ~ g r u p o s ~ p o l i ́ t i c o s ~ c o n c o r r e m ~ p a r a ~ a ~ e x p r e s s a ̃ o ~ d o ~ s u f r a ́ g i o . ~ F o r m a m-s e ~ e ~}$ exercem sua atividade livremente. Eles devem respeitar os princípios da soberania nacional e da democracia.Eles contribuem à aplicação do princípio enunciado na última alínea do art. 3 nas condições determinadas pela lei".

211 "Art. 49. Todos os cidadãos têm o direito de se associarem livremente em partidos para concorrer pelo método democrático para determinar a política nacional".

212 "Artigo $10^{\circ}$ - (Sufrágio universal e partidos políticos)

1. O povo exerce o poder político através do sufrágio universal, igual, direto, secreto e periódico, do referendo e das demais formas previstas na Constituição.

2. Os partidos políticos concorrem para a organização e para a expressão da vontade popular, no respeito pelos princípios da independência nacional, da unidade do Estado e da democracia política".

${ }^{213}$ Cf. Andrés Serra Rojas, "Partido político", in Andrés Serra Rojas, Diccionario de ciencia política, 2. ed., 1. reimp., 2001, p. 832.

${ }^{214}$ Rodrigo Borja, "Partido político", in Rodrigo Borja, Enciclopedia de la política, 2. ed. rev. e aum., México: Fondo de Cultura Económica, 1998, p. 768.
} 
Apesar do reconhecimento constitucional de sua importância para os respectivos sistemas políticos nacionais, os partidos sofreram um processo de enfraquecimento, nos âmbitos interno e externo.

Os partidos perderam prestígio e credibilidade entre a população por diversos fatores, entre eles a ocorrência de diversos casos de corrupção em diversos países, a discrepância entre a vontade popular e os atos partidários no Legislativo ou no Governo e também a diminuição do caráter ideológico dos partidos ${ }^{215}$.

Internamente, percebeu-se não só a diminuição do número de filiados, mas também uma grande redução não só do tempo despendido com as atividades partidárias, mas também uma diminuição dos recursos doados a título de contribuição financeira pelos filiados $^{216}$.

Estes acontecimentos deram para a sociedade a impressão de que os partidos existiam somente para a promoção de assuntos de interesse exclusivo dos próprios políticos ou daqueles que contribuem diretamente para os partidos, primordialmente aqueles que fazem doações financeiras para a manutenção da máquina partidária ou para as campanhas eleitorais, sendo deixadas de lado as aspirações populares ${ }^{217}$.

Ademais, somada à queda do montante de recursos advindos dos filiados, notouse também uma maior exigência organizacional dos partidos políticos. A televisão tornava-se o principal meio de comunicação na sociedade (e da mesma forma, aos partidos), o que gerou uma maior necessidade de recursos para que os partidos pudessem aprimorar a comunicação com a sociedade por esse novo veículo. Houve também uma maior exigência organizacional dentro dos partidos, com contratação de pessoas especializadas, por exemplo, em pesquisas de opinião, comunicação e marketing político $^{218}$.

\footnotetext{
${ }^{215}$ Cf. Rodrigo Borja, "Partido polítiico", p. 768 e Toti S. Musumeci, Il costo della politica ed il finanziamento ai partiti, Padova: CEDAM, 1999, p. 46.

${ }^{216} \mathrm{Cf}$. Toti S. Musumeci, Il costo della política ed il finanziamento ai partiti, p. 46.

${ }^{217}$ Cf. Rodrigo Borja, "Partido político", p. 768.

${ }^{218}$ Cf. José Woldenberg, "Relevancia y actualidad de la contienda", p. 18.
} 
A queda da arrecadação entre as "fontes tradicionais" da política veio, portanto, de encontro com a crescente necessidade de recursos para que os partidos pudessem competir com chances nas eleições. Este impasse vivido pelos partidos pode ser resumido pelas palavras de Toti Musumeci, que afirma que as legendas tinham a necessidade de adquirir em caráter definitivo, irreversível uma nova estrutura organizativa, mas ao mesmo tempo eram incapazes de fazer frente às suas exigências funcionais e estruturais vivendo e dependendo somente do autofinanciamento lícito e transparente ${ }^{219}$.

Assim, diante do quadro de queda na arrecadação e crescimento dos gastos, houve a instituição em vários países de um sistema normativo de financiamento da atividade política de caráter misto, ou seja, mantendo-se a previsão legal de doações privadas aos partidos e às campanhas eleitorais, mas também reservando parte de recursos do orçamento público para o pagamento das despesas de manutenção das estruturas partidárias e das campanhas eleitorais.

A criação de dispositivos legais que prevêem parte do dinheiro a ser utilizado pelos partidos e candidatos em suas atividades ressaltou o valor que os partidos políticos ganharam no ordenamento jurídico desde o fim da II Guerra Mundial. Sua importância para o funcionamento do sistema democrático, bem como seu autêntico caráter de entidade de interesse público justificariam a destinação de recursos públicos para o pagamento de duas despesas cotidianas.

Além de enfatizar o partido como principal instrumento para o jogo democrático, a obrigatoriedade legal de alocar recursos públicos para a sustentação financeira dos partidos políticos (e de suas campanhas eleitorais, por conseqüência) tem, da mesma forma, outros objetivos.

O primeiro deles é garantir maior eqüidade na competição eleitoral. As legislações que prevêem alocação de recursos públicos para os partidos políticos se sustentarem e também financiarem suas campanhas nos períodos eleitorais concedem às legendas e aos seus respectivos candidatos um montante mínimo para competir nas

${ }^{219}$ Cf. Toti S. Musumeci, Il costo della política ed il finanziamento ai partiti, p. 45. 
eleições, independentemente de o candidato ou o partido ser mais rico ou não, ou de o seu potencial eleitorado também ser mais abastado ou não ${ }^{220}$.

O segundo objetivo dos dispositivos legais de financiamento público da atividade política é garantir uma maior independência aos partidos políticos com relação aos seus possíveis doadores privados. Com uma parcela de recursos de origem pública, os partidos conseqüentemente não ficariam tão dependentes de seus doadores privados.

É forçoso reconhecer que muitos doadores privados, notadamente pessoas jurídicas, doam recursos aos partidos e às campanhas com o escopo de conseguir favorecimentos futuros, no caso de vitória eleitoral do candidato donatário ou do partido receptor das doações, em flagrante cometimento de corrupção e/ou tráfico de influência.

Com mais recursos públicos, os partidos e os candidatos tornar-se-iam automaticamente menos dependentes dos recursos privados, o que pode garantir maior independência no exercício do mandato, reduzindo em tese o impacto do poder econômico de origem privada ${ }^{221}$. No mesmo sentido, o financiamento público pode evitar que os partidos e seus candidatos procurem se acudir em fontes ilegítimas de financiamento, já que recebem recursos públicos que garantiriam pelo menos o mínimo necessário para poderem competir nas eleições ${ }^{222}$.

A transparência na arrecadação dos recursos é outro objetivo do financiamento público da política. Primeiramente, constata-se que com uma predominância de recursos com origem numa mesma fonte (os cofres públicos), haverá uma maior facilidade de controle na arrecadação pelos órgãos fiscalizadores ${ }^{223}$. Além disso, por se tratarem de recursos públicos dos contribuintes, haveria um melhor controle dos respectivos gastos,

\footnotetext{
${ }^{220}$ Corroboram com essa afirmação José Woldenberg ("Relevancia y actualidad de la contienda”, p. 20.), David Samuels ("Financiamento de campanha e eleições no Brasil: o que podemos aprender com o "caixa um' e propostas de reforma", p. 384) e Jairo Nicolau ("Para reformar o financiamento de campanhas no Brasil", p. 9)

${ }^{221}$ Cf. Jairo Nicolau, "Para reformar o financiamento de campanhas no Brasil", p. 9.

${ }^{222}$ Cf. José Woldenberg, "Relevancia y actualidad de la contienda", p. 20.

${ }^{223}$ Cf. Marcelo Passamani Machado, "O financiamento das campanhas eleitorais: perspectivas para uma reforma política", p. 202.
} 
havendo também maior pressão popular pelo seu controle e para a real aplicação do princípio da transparência ${ }^{224}$.

Os partidos sairiam fortalecidos com o sistema público de financiamento da atividade política, pois seriam os principais responsáveis pela distribuição dos recursos entre seus filiados postulantes e também pela administração do montante ${ }^{225}$.

Por fim, o financiamento público evita também uma distorção da representação política. Se o candidato foi eleito após realizar uma campanha eleitoral em que os recursos privados foram predominantes, sua atuação no exercício do mandato pode ficar vinculada aos interesses do doador e não de seu eleitorado "comum", defendendo propostas que defendem interesses particulares em detrimento do bem público.

Ademais, as camadas sociais que não tem qualquer condição econômica de fazer doações aos partidos e aos candidatos tornar-se-ia "subrepresentada" nos órgãos políticos (menos candidatos desse eleitorado seriam eleitos), enquanto que a classe mais abastada tornar-se-ia "super representada" - com mais dinheiro, mais candidatos representantes dos ricos e das pessoas jurídicas seriam eleitos ${ }^{226}$.

Bruno Wilhelm Speck critica o fato de a legislação brasileira prever como limites para as quantias doadas às campanhas eleitorais uma porcentagem do rendimento financeiro obtido pela pessoa física ou jurídica, independentemente se este rendimento foi alto ou baixo, indicando que este limite atualmente vigente pode ocasionar a "super representação" da classe mais abastada ou de pessoas jurídicas, conforme trecho a seguir:

Por que um cidadão com renda mais alta está autorizado a contribuir mais para campanhas do que seu vizinho, que tem rendimentos menores? Semelhante dispositivo talvez nem resista a um questionamento sério quanto à sua

\footnotetext{
${ }^{224}$ Cf. Daniel Zovatto, "Financiamento dos partidos e campanhas eleitorais na América Latina: uma análise comparada", in Opinião Pública, v. XI, n. 2, out./2005, p. 299.

${ }^{225}$ Cf. Marcelo Passamani Machado, "O financiamento das campanhas eleitorais: perspectivas para uma reforma política", p. 203.

${ }^{226}$ Cf. Delia Ferreira Rubio, "Financiamento de partidos e campanhas: fundos públicos versus fundos privados", in Novos Estudos Cebrap, n. 73, nov./2005, p. 8. No mesmo sentido, Marcelo Passamani Machado, "O financiamento das campanhas eleitorais: perspectivas para uma reforma política", p. 208.
} 
constitucionalidade, uma vez que transforma em norma a desigualdade dos cidadãos no processo eleitoral $^{227}$.

O financiamento público, apesar das vantagens acima relacionadas, apresenta também algumas desvantagens, conforme apontam os estudiosos do tema.

O primeiro problema a ser apontado é o fato de que a adoção de um sistema predominante ou exclusivamente público não garante o fim da arrecadação de recursos de fonte ilegal ou em paralelo à contabilidade do partido ou da campanha eleitoral ${ }^{228}$. Fernando Neves, da mesma forma, concorda com este diagnóstico, asseverando inclusive que se adotado sistema público de financiamento da política, quase certamente ocorrerão doações privadas em paralelo 229 .

David Samuels também indica que a adoção do sistema público implicará no fortalecimento dos partidos políticos. Afirma, no entanto, que este fortalecimento pode ser excessivo, pois com o órgão partidário nacional incumbido de controlar o repasse do dinheiro aos seus filiados candidatos, pode ocorrer o favorecimento financeiro de candidatos alinhados à direção partidária, em detrimento de outros menos alinhados ${ }^{230}$.

Outro argumento contrário, presente principalmente nos países pobres ou em desenvolvimento, é o fato de o montante total previsto no orçamento público nunca ter recursos suficientes para as áreas sociais. Renato Janine Ribeiro indica que este é um dos principais argumentos utilizados pelos críticos do financiamento público da política, conforme trecho a seguir:

\footnotetext{
${ }^{227}$ Bruno Wilhelm Speck, "Cinco teses sobre o financiamento da competição política e a proposta da respectiva reforma", in Revista Jurídica Consulex, ano VIII, n. 179, jun.2004, p. 37.

${ }_{228}$ Apóia essa afirmação Jairo Nicolau, "Para reformar o financiamento de campanhas no Brasil", p. 9. Bruno Wilhelm Speck corrobora da mesma forma, enfatizando inclusive que a instituição do sistema e financiamento exclusivamente público no Brasil remontaria à legislação vigente no país até as eleições de 1992, sistema esse alijado do ordenamento jurídico brasileiro após as denúncias contra o então presidente da República Fernando Collor de Mello (Cf. Bruno Wilhelm Speck, "Cinco teses sobre o financiamento da competição política e a proposta da respectiva reforma", p. 36). David Samuels, da mesma maneira, concorda com a afirmação, asseverando inclusive a necessidade de reformas na legislação bancária e tributária caso o financiamento exclusivamente público de campanhas venha a ser adotado no Brasil (Cf. David Samuels, "Financiamento de campanha e eleições no Brasil: o que podemos aprender com o "caixa um' e propostas de reforma", p. 384).

${ }^{229}$ Cf. Fernando Neves da Silva, "Financiamento de campanha política e corrupção eleitoral", p. 37.

${ }^{230}$ Cf. David Samuels, "Financiamento de campanha e eleições no Brasil: o que podemos aprender com o 'caixa um' e propostas de reforma", p. 386.
} 
Os oponentes do financiamento público afirmam que dinheiro precioso seria desviado de fins mais nobres - a educação, a saúde, a segurança - para alimentar a atividade político-partidária ${ }^{231}$.

Não havendo recursos para as áreas mais importantes a serem bancadas pelo Estado, não haveria sentido em haver dotações orçamentárias para bancar a estrutura dos partidos políticos, quanto mais suas campanhas eleitorais ${ }^{232}$.

A busca dos partidos e dos candidatos por dinheiro entre o eleitorado e as pessoas jurídicas, segundo Jairo Nicolau e Bruno Wilhelm Speck, não é um mal em si. Nicolau afirma que a adoção de um sistema exclusivamente público violaria, inclusive, o direito de os "indivíduos contribuírem com os partidos e os candidatos que defendem suas causas", pois "a busca de apoio financeiro é um mecanismo fundamental para dar vitalidade aos partidos e envolver cidadãs e cidadãos nas campanhas políticas" ${ }^{233}$.

Para Bruno Speck, a existência de dispositivos legais que permitam o financiamento privado favorece o fortalecimento dos laços entre os partidos políticos e a sociedade. Segundo o autor, as doações feitas por filiados é uma espécie de "reflexo do enraizamento social dos partidos", e as contribuições feitas por doadores não filiados (pessoas físicas ou jurídicas) são "manifestações legítimas de apoio às candidaturas"234.

Outro argumento apresentado na doutrina que vai contra a adoção do sistema de financiamento público é o fato de a necessidade de controle da arrecadação de recursos e de transparência nas movimentações financeiras e nos momentos de prestações de contas serem no mínimo do mesmo tamanho que nos sistemas de financiamento privado, não havendo assim nenhuma vantagem na adoção do sistema exclusivamente público.

\footnotetext{
${ }^{231}$ Renato Janine Ribeiro, "Financiamento de campanha (público versus privado)", p. 78.

${ }^{232}$ Cf. Fernando Neves da Silva, "Financiamento de campanha política e corrupção eleitoral", p. 38; Monica Herman Salem Caggiano, Direito parlamentar e direito eleitoral, p. 143; e Eurico A. Gonzalez Cursino dos Santos. "Comentários ao PL 2.679/2003, da Comissão de Reforma Política da Câmara dos Deputados", p. 19.

${ }^{233}$ Jairo Nicolau, "Para reformar o financiamento de campanhas no Brasil", p. 10.

${ }^{234}$ Bruno Wilhelm Speck, "Cinco teses sobre o financiamento da competição política e a proposta da respectiva reforma", p. 36. No mesmo sentido, Delia Ferreira Rubio, "Financiamento de partidos e campanhas: fundos públicos versus fundos privados", p. 11.
} 
O controle e a transparência no sistema exclusivamente público, mesmo com a vantagem de haver uma única fonte, deve ter a mesma importância que a existente em um sistema misto ou em um sistema com forte predominância de recursos privados, pois além de se lidar com recursos dos contribuintes, há a possibilidade de os candidatos utilizarem estes recursos para o pagamento de gastos particulares, ao invés de gastá-los em suas campanhas ${ }^{235}$.

Ademais, no caso específico brasileiro, a adoção do sistema exclusivamente público sujeitaria a Justiça Eleitoral, órgão responsável pelo controle e pela promoção da transparência nas contas partidário-eleitorais, a uma maior pressão não só da sociedade como também dos próprios políticos, principalmente após decisões em que houvesse a determinação da suspensão do repasse dos recursos a uma legenda ou uma candidatura $^{236}$.

Apesar de o financiamento privado não apresentar mecanismos que privilegiem a eqüidade de condições para a competição eleitoral entre candidatos e partidos, há um importante fator presente em todos os sistemas de financiamento público que também pode distorcer a igualdade de condições entre as legendas concorrentes e seus respectivos candidatos: o método legal de distribuição dos recursos entre os partidos.

Delia Ferreira Rubio, Bruno Wilhelm Speck e Toti S. Musumeci apontam que a instituição legal do critério do "sucesso eleitoral" para a distribuição dos recursos entre os partidos gera a manutenção do status quo partidário, e não a promoção de novas legendas e novos candidatos por meio da igualdade de condições para a competição eleitoral $^{237}$.

Este método, também chamado de "critério da força eleitoral" por Daniel Zovatto, é adotado em diversos países da América Latina ${ }^{238}$, consiste em repassar para

\footnotetext{
${ }^{235}$ Cf. Jairo Nicolau, "Para reformar o financiamento de campanhas no Brasil", p. 9.

${ }^{236}$ Cf. Bruno Wilhelm Speck, "Cinco teses sobre o financiamento da competição política e a proposta da respectiva reforma", p. 36.

${ }^{237}$ Cf. Delia Ferreira Rubio, "Financiamento de partidos e campanhas: fundos públicos versus fundos privados", p. 9; Bruno Wilhelm Speck, "Cinco teses sobre o financiamento da competição política e a proposta da respectiva reforma", p. 36; e Toti S. Musumeci, Il costo della politica ed il finanziamento ai partiti, p. 67.

${ }^{238} \mathrm{O}$ critério da força eleitoral, segundo Daniel Zovatto, é o único previsto nas legislações partidárioeleitorais de Bolívia, Colômbia, Costa Rica, Chile, El Salvador, Guatemala, Honduras, Nicarágua e
} 
os partidos os recursos destinados ao financiamento público de acordo com a votação obtida por cada legenda na última eleição: portanto, os partidos recebem recursos em valores proporcionais à votação recebida no último pleito - quanto mais votos obtidos, mais dinheiro a receber; com menos votos, menos dinheiro, e conseqüentemente menor chance de um maior sucesso nas próximas eleições.

José Woldenberg enfatiza que o método de distribuição baseado no sucesso do partido nas últimas eleições reforça a necessidade dos partidos não tão bem sucedidos em arrecadar recursos na iniciativa privada, fatos este que pode calhar em nova escalada dos gastos de campanha e anular algumas das vantagens trazidas pelos mecanismos legais de financiamento público da atividade política $^{239}$.

Delia Ferreira Rubio destaca que o método de divisão dos recursos pode tornarse uma possibilidade legislativa para o governo de ocasião execute manobras legislativas no intuito de "criar obstáculos para a atuação política dos grupos de oposição",240.

A dependência dos partidos políticos em relação a suas fontes financeiras é um problema a ser resolvido pelos legisladores tanto no sistema público quanto no sistema de financiamento privado da atividade política.

Como já visto anteriormente, a necessidade de arrecadar-se dinheiro entre a iniciativa privada pode ser ruim, pois há a chance de os laços criados entre doadores e partidos/candidatos terem sido feitos para que haja a prática de atos de corrupção ou de tráfico de influência.

Os sistemas nos quais predominam os recursos públicos, no entanto, criam da mesma maneira uma dependência dos partidos com relação à sua fonte financeira, mas em relação ao Estado, principalmente em países em que cabe a um órgão governamental

Uruguai. Já Brasil, Argentina, Equador, México, Panamá, Paraguai, Peru e República Dominicana adotam dispositivos legais que prevêem parte dos recursos públicos distribuídos às legendas conforme sua respectiva força eleitoral e outra parte dividida igualmente entre os partidos. (Cf. Daniel Zovatto, "Financiamento dos partidos e campanhas eleitorais na América Latina: uma análise comparada", p. 303304).

${ }^{239}$ Cf. José Woldenberg, "Relevancia y actualidad de la contienda", p. 22-23.

240 Delia Ferreira Rubio, "Financiamento de partidos e campanhas: fundos públicos versus fundos privados", p. 11. 
a administração dos recursos (e não a um órgão independente). A maior dependência dos recursos estatais distancia, conforme visto anteriormente, os partidos da sociedade, podendo aprofundar a crise de credibilidade vivida pelas legendas ${ }^{241}$.

Apesar de reconhecerem que o tema é importante para a "qualidade e estabilidade da democracia" ${ }^{242}$, recheado de polêmicas e de afirmarem que não há uma "solução universal"243 para o problema, eis que devem ser analisados "o contexto histórico e cultural em que se desenvolvem as atividades dos partido" e "as características do sistema de governo, as regras eleitorais, o sistema partidário e mesmo as práticas que informam a vida política" ${ }^{244}$, os autores aqui estudados defendem a instituição de sistemas mistos como o melhor caminho a ser percorrido pelos países que atualmente enfrentam problemas na área ${ }^{245}$, alguns fazendo propostas específicas ao caso brasileiro.

Para tanto, os autores sugerem uma série de novos mecanismos a serem adotados no sistema normativo do financiamento misto para tentar dirimir os efeitos negativos existentes tanto no sistema público quanto no sistema privado.

A primeira sugestão é o aprimoramento dos mecanismos de controle e de transparência nas contas partidárias eleitorais. Fernando Neves, por exemplo, sugere no caso brasileiro que a Justiça Eleitoral faça, antes de cada período eleitoral, uma colheita de dados visando informar-se a respeito dos preços de mercado dos principais tipos de gastos de uma campanha eleitoral, como despesas com pessoal, transporte, aluguel de

\footnotetext{
${ }^{241}$ Cf. Delia Ferreira Rubio, "Financiamento de partidos e campanhas: fundos públicos versus fundos privados", p. 10; e Marcelo Passamani Machado, "O financiamento das campanhas eleitorais: perspectivas para uma reforma política", p. 206.

${ }_{242}$ Daniel Zovatto, "Financiamento dos partidos e campanhas eleitorais na América Latina: uma análise comparada", p. 288.

${ }^{243}$ Cf. Delia Ferreira Rubio, "Financiamento de partidos e campanhas: fundos públicos versus fundos privados", p. 7.

${ }^{244}$ Delia Ferreira Rubio, "Financiamento de partidos e campanhas: fundos públicos versus fundos privados", p. 7.

${ }^{245}$ Cf. Daniel Zovatto, "Financiamento dos partidos e campanhas eleitorais na América Latina: uma análise comparada", p. 301; Delia Ferreira Rubio, "Financiamento de partidos e campanhas: fundos públicos versus fundos privados", p. 10; David Samuels, "Financiamento de campanha e eleições no Brasil: o que podemos aprender com o 'caixa um' e propostas de reforma", p. 388; Jairo Nicolau, "Para reformar o financiamento de campanhas no Brasil", p. 9; Fernando Neves da Silva, "Financiamento de campanha política e corrupção eleitoral", p. 38; Bruno Wilhelm Speck, "Cinco teses sobre o financiamento da competição política e a proposta da respectiva reforma", p. 37.
} 
bens móveis e imóveis, material de propaganda, contratação de pesquisas, entre outros $^{246}$.

Essa colheita serviria como parâmetro para que a Justiça Eleitoral, no momento de verificação das contas eleitorais, percebesse eventual sub ou superfaturamento, criando melhores condições para a punição dos candidatos e partidos que cometessem irregularidades.

Ante o grande número de prestações de contas a serem analisadas, Jairo Nicolau defende que a Justiça Eleitoral faça um sistema de auditagem por sorteio. As contas sorteadas seriam aquelas em que a Justiça promoveria rigoroso controle, consistindo esse sistema como espécie de desestímulo ao cometimento de irregularidades ${ }^{247}$.

As prestações de contas, da mesma forma, deveriam ser alvo de reforma legislativa, no sentido de desenvolver uma melhor sistematização, separando as grandes das pequenas doações, pois é mais importante para efeito de fiscalização o monitoramento das grandes doações, e não das contribuições de baixo valor ${ }^{248}$. Ademais, a transparência com relação às fontes financeiras dos partidos e candidatos garante ao eleitorado a possível verificação entre a coerência do discurso do candidato e a postura dos partidos nas eleições e os atos exercidos no decurso do mandato ${ }^{249}$.

A obrigatoriedade dos partidos e candidatos prestarem contas não só ao final do período eleitoral, mas também durante a campanha é defendida por David Samuels como método capaz de assegurar maior facilidade de controle por parte da Justiça Eleitoral no momento de julgamento da prestação de contas e também para dificultar eventuais manobras contábeis feitas pelos partidos ou candidatos após o encerramento das eleições ${ }^{250}$. Esta proposta também facilitaria o controle da mídia e do eleitorado em relação à arrecadação de respectivas despesas durante a campanha.

\footnotetext{
${ }^{246}$ Cf. Fernando Neves da Silva, "Financiamento de campanha política e corrupção eleitoral", p. 39.

${ }^{247}$ Cf. Jairo Nicolau, "Para reformar o financiamento de campanhas no Brasil", p. 11.

${ }^{248}$ Cf. Jairo Nicolau, "Para reformar o financiamento de campanhas no Brasil", p. 12.

${ }^{249}$ Cf. Daniel Zovatto, "Financiamento dos partidos e campanhas eleitorais na América Latina: uma análise comparada", p. 317.

${ }^{250}$ Cf. David Samuels, "Financiamento de campanha e eleições no Brasil: o que podemos aprender com o ‘caixa um' e propostas de reforma", p. 389-390.
} 
Os estudiosos também sugerem a instituição de normas que prevejam rigorosas sanções, inclusive de caráter criminal (e não somente a aplicação de multas pecuniárias), para aqueles que por ventura cometam irregularidades ${ }^{251}$. As sanções de caráter político, como a subordinação da expedição do diploma à aprovação das contas pela Justiça Eleitoral, são defendidas no caso brasileiro por Fernando Neves ${ }^{252}$.

Por fim, o regime legal dos limites de doações deve ganhar especial atenção do legislador. No caso brasileiro, David Samuels e Bruno Wilhelm Speck afirmam que a legislação brasileira deve ser reformada no sentido de mudar as disposições legais que tratam dos limites às doações.

Para Samuels, a redução do limite de doação, devendo o limite ser fixado em valor monetário e não em porcentagem da renda obtida pelo doados no ano anterior à eleição, é medida imperativa para a diminuição da influência do poder econômico no âmbito eleitoral $^{253}$. Já Bruno Wilhelm Speck, ao advogar a favor do sistema misto de financiamento da atividade política, também foca a questão dos limites às doações. Alega o autor que são as grandes contribuições que geram os problemas aqui apontados ao sistema brasileiro, pois são elas que podem caracterizar a dependência entre candidato e doador. Para a resolução do problema, Speck defende que o limite deve ser reduzido, para que também aumente o número de doadores no intuito de os candidatos não ficarem presos a poucos doadores, conforme trecho a seguir:

Já se o candidato conseguir diversificar as suas fontes de financiamento, poderá dispensar aquelas que vinculam o seu apoio financeiro à lógica do toma-lá-dá-cá. Concluindo: o problema do financiamento privado não reside na origem privada dos recursos. Esta tem até efeitos benéficos, desde que mantidos determinados patamares máximos quanto aos montantes que se pode doar. O vício está na diferença entre contribuições pequenas, saudáveis, e outras, de valor elevado, que

\footnotetext{
${ }^{251}$ Cf. Jairo Nicolau, "Para reformar o financiamento de campanhas no Brasil", p. 11. Daniel Zovatto corrobora com a necessidade de dispositivos legais que determinem sanções duras aos que cometem irregularidade. No entanto, o autor alerta para o risco de os legisladores se excederem ao definirem as penas para tais condutas, gerando o fenômeno do "excesso de regulamentação" ou o da "criminalização da política". Assim, ao definir o regime de sanções, deve o legislador agir com prudência e "buscar o equilíbrio necessário" para que não se exceda. (Daniel Zovatto, "Financiamento dos partidos e campanhas eleitorais na América Latina: uma análise comparada", p. 319-322).

${ }^{252}$ Cf. Fernando Neves da Silva, "Financiamento de campanha política e corrupção eleitoral", p. 39.

${ }^{253}$ Cf. David Samuels, "Financiamento de campanha e eleições no Brasil: o que podemos aprender com o ‘caixa um' e propostas de reforma", p. 388-389.
} 
tornam a competição desigual e estabelecem vínculos de dependência, tornando a representação viciada na origem ${ }^{254}$.

Estudados os principais aspectos do sistema político-eleitoral brasileiro, as principais propostas de reforma deste sistema e com maior profundidade as vantagens e desvantagens que cada tipo de sistema normativo de financiamento da atividade política traz ao ser adotado, passar-se-á à análise do sistema normativo vigente atualmente no que se refere ao financiamento da atividade política no Brasil.

${ }^{254}$ Bruno Wilhelm Speck, "Cinco teses sobre o financiamento da competição política e a proposta da respectiva reforma", p. 37. 


\section{SISTEMA NORMATIVO DO FINANCIAMENTO DA POLÍTICA NO BRASIL}

Neste capítulo, será tratado todo o sistema normativo que rege o financiamento da política no Brasil. Serão analisados aqui todos os dispositivos no ordenamento jurídico brasileiro que estão relacionados à arrecadação de capital, de bens e de serviços para que as campanhas eleitorais e os partidos políticos possam funcionar.

Todas as regras concernentes ao financiamento da atividade política no Brasil, tanto no que se refere aos partidos políticos como às campanhas eleitorais têm por objetivo garantir a normalidade e a legitimidade das eleições, evitando-se que elas venham a ser maculadas por partidos ou candidatos que eventualmente cometam atos de abuso do poder econômico capazes de ferir a igualdade entre os candidatos e a real vontade do eleitorado ao decidir seu voto ${ }^{255}$, em respeito ao ditame constitucional previsto no art. $14, \S 9^{\circ}$.

O estudo dessas regras será iniciado com a análise do texto da Lei das Eleições (Lei n. 9.504/97), norma esta que dispõe sobre o financiamento das campanhas eleitorais. Há quatro itens para serem abordados no que toca à Lei das Eleições: (i) arrecadação, administração e aplicação de recursos nas campanhas; (ii) dispositivos sobre as doações: a forma de se doar, os limites, as vedações constitucionais e legais e as penas para a desobediência do texto da lei; (iii) o rol de despesas legais a serem feitas em uma campanha eleitoral; (iv) as normas relativas às prestações de contas de campanha.

Após a abordagem da legislação referente às campanhas eleitorais, serão discutidos os dispositivos referentes ao financiamento dos partidos políticos no Brasil. Assim, estudar-se-á a Lei dos Partidos Políticos (Lei n. 9.096/95), com ênfase nas finanças e contabilidade dos partidos, no Fundo Partidário e no Horário Eleitoral e Partidário Gratuito.

\footnotetext{
${ }^{255}$ Cf. Vera Maria Nunes Michels, Direito eleitoral: de acordo com a Constituição Federal, LC 64/90, Lei 9.096/95 e Lei 9.504/97, p. 183-184.
} 
Em seguida, os crimes eleitorais referentes ao financiamento das campanhas eleitorais e dos partidos políticos serão examinados. Todos estes crimes estão previstos no Código Eleitoral (Lei n. 4.737/65). Posteriormente, há o exame da Lei das Inelegibilidades (Lei Complementar n. 64/90), que dispõe sobre as hipóteses de abuso do poder econômico e também sobre o rito processual da apuração do cometimento do abuso.

\subsection{Lei das Eleições (Lei n. 9.504/97)}

3.1.1. Arrecadação, administração e aplicação de recursos nas campanhas eleitorais

O capítulo da Lei das Eleições que contém as disposições relativas ao financiamento das campanhas eleitorais, intitulado "Da Arrecadação e da Aplicação de Recursos nas Campanhas Eleitorais" tem em seu primeiro artigo (art. 17) a determinação sobre de quem é a responsabilidade sobre as despesas da campanha eleitoral: partidos políticos ou de seus candidatos. Firma-se, nas palavras de Joel Cândido, o "princípio da responsabilidade financeira solidária" entre os partidos e os candidatos $^{256}$.

Há em seguida dispositivo incluído pela Lei n. 11.300/06 (a chamada minirreforma eleitoral), lei esta que tinha por objetivo principal reduzir os gastos de campanha no país. Para tanto, incluiu na Lei das Eleições do art. 17-A, que dispõe sobre os limites de gastos de cada campanha.

Os limites de gastos serão estabelecidos por lei a ser editada até 10 de junho de cada ano eleitoral, limites estes que observarão as peculiaridades locais. No caso de esta lei não ser editada até a data fixada, cabe ao partido político fixar o limite de gastos, comunicando a Justiça Eleitoral sobre esses limites fixados, que serão amplamente publicados pela Justiça.

\footnotetext{
${ }^{256}$ Cf. Joel J. Cândido, Direito eleitoral brasileiro, p. 433.
} 
A observação das "peculiaridades locais" traz ao legislador a possibilidade de ele fixar os critérios para o estabelecimento desses limites, podendo-se criar critérios das mais diversas referências, como o populacional (o Estado com maior população tem um limite maior), o geográfico (o Estado com maior território tem um limite diferente), o de número de candidatos registrados (um alto número de candidatos gera maior competição, fazendo com que esse Estado tenha um limite maior), por exemplo.

Essa possibilidade abre brecha para que a lei provada com os limites estabelecidos possa, deliberada ou acidentalmente, beneficiar alguns partidos e candidatos em detrimento de seus adversários ${ }^{257}$, pois facilita casuísmos ${ }^{258}$.

Há também a alegação de que o artigo ora é comento é eivado de inconstitucionalidade, por desrespeitar o princípio constitucional da anterioridade eleitoral (art. 16 da Constituição). Este princípio prescreve que qualquer lei que altere o processo eleitoral deve ser publicada ao menos um ano antes da data da eleição pra que tenha sua vigência já no próximo pleito. O art. 17-A da LE prevê que a norma fixadora dos limites de gastos nas campanhas possa entrar em vigor para valer já na eleição seguinte em até 10 de junho do ano eleitoral, havendo assim flagrante desrespeito ao determinado no art. 16 da Constituição. Além disso, a edição de uma lei fixadora de gastos eleitorais a cada eleição ressuscita a tão criticada instabilidade legislativa no campo político-eleitoral ${ }^{259}$.

Também não prevê o artigo critérios para a obrigatoriedade de "ampla publicidade" aos limites estabelecidos pelos partidos, ficando a critério da Justiça Eleitoral a interpretação deste termo.

Não havendo a edição da lei (aliás, nem na eleição de 2006 e nem na de 2008 houve), cabe então ao partido político fixar seus limites de gasto, comunicando à Justiça Eleitoral sobre os mesmos no momento de registro das candidaturas de seus filiados (art. 18, caput). Havendo coligação partidária, cada partido participante poderá fixar

\footnotetext{
${ }^{257}$ Cf. Joel J. Cândido, Direito eleitoral brasileiro, p. 434.

${ }^{258}$ Cf. Renato Ventura Ribeiro, Lei eleitoral comentada, p. 166.

259 Cf. Joel J. Cândido, Direito eleitoral brasileiro, p. 435; Renato Ventura Ribeiro, Lei eleitoral comentada, p. 166; e Roberto Porto, Lei eleitoral anotada: Lei n. 9.504, de 30 de setembro de 1997, São Paulo: Saraiva, 2009, p. 44.
} 
limites diversos, devendo cada partido informar a Justiça Eleitoral separadamente, se for o caso (art. 18, inciso I).

A incumbência da fixação do limite de gastos a serem realizados nas campanhas eleitorais deveria ser sempre do partido ou do candidato, já que são eles quem faz todo o planejamento necessário para a consecução de uma campanha eleitoral, conhecedores notórios que são de todas as nuances existentes numa corrida eleitoral capazes de afetar ou não o caixa financeiro de uma campanha ${ }^{260}$, em respeito à autonomia partidária prevista constitucionalmente (art. 17, § $\left.1^{\circ}\right)$.

Havendo descumprimento dos limites declarados, o candidato ou o partido pagará multa de cinco a dez vezes equivalente ao valor gasto em excesso (art. 18, inciso II), podendo o responsável também responder por abuso do poder econômico (art. $2^{\circ}, \S$ $4^{\circ}$ da Resolução TSE n. 22.715/08).

A fixação de limites, na prática, não serve de parâmetro para um melhor controle da arrecadação e da aplicação de recursos nas campanhas eleitorais. A fixação por meio de lei pode acarretar problemas, conforme acima visto.

Ademais, conferir tamanha liberdade aos partidos políticos pode ocasionar também a ineficácia do dispositivo. A legenda pode, por exemplo, fixar valor muito alto, fora da realidade, com o escopo de não haver a possibilidade de infringir o limite declarado e o conseqüente pagamento de multa.

Ao fixar limite muito alto, pode também ocorrer de o partido chamar a atenção dos adversários, da Justiça Eleitoral e da própria sociedade, gerando um efeito negativo para suas campanhas. Mas também ao estabelecer limite baixo (decorrente de um planejamento financeiro ruim, por exemplo), ficam seus candidatos limitados em sua capacidade administrativo-financeira de suas campanhas. Há também a possibilidade de o limite ser alterado a pedido do candidato, com a devida autorização da Justiça Eleitoral, devendo o pedido ser justificado na ocorrência de fatos supervenientes e

\footnotetext{
${ }^{260}$ Corrobora com esta afirmação Joel J. Cândido, Direito eleitoral brasileiro, p. 437.
} 
imprevisíveis, fatos estes que inviabilizem o cumprimento do limite originalmente estabelecido (art. $2^{\circ}, \S 5^{\circ}$ da Resolução TSE n. 22.715/08).

A arrecadação e aplicação de recursos para as campanhas eleitorais podem ser administradas não só pelo candidato, mas também por um comitê financeiro, conforme previsão contida no art. 19 da LE.

Esses comitês devem ser constituídos pelo partido em até dez dias úteis após a realização da Convenção partidária que escolheu quais filiados serão seus candidatos nas eleições (art. 19, caput) Constituídos, os partidos devem registrá-los em até cinco dias nos órgãos competentes da Justiça Eleitoral (art. 19, § $3^{\circ}$ ). Portanto, os comitês municipais devem ser registrados perante o juiz eleitoral; os estaduais, nos Tribunais Regionais Eleitorais; o nacional, no TSE.

Em cada eleição para a qual o partido tenha candidato, deve a legenda constituir um comitê. Pode a legenda reunir, em um único comitê, as atribuições relativas às eleições de uma circunscrição ( $\operatorname{art.} 19, \S 1^{\circ}$ ).

$\mathrm{Na}$ prática, isso significa que, por exemplo, na eleição municipal, em cada cidade em que tiver candidato, o partido terá duas possibilidades: (i) abrir um comitê único (englobando a eleição majoritária e a proporcional); ou (ii) abrir um comitê para a eleição majoritária e outra para a eleição proporcional. Se não tiver candidato na eleição para prefeito, basta abrir comitê para a eleição de vereador.

Na eleição estadual, pode então a legenda fazer da seguinte forma: (i) comitê financeiro único (englobando as eleições para governador, senador, deputado federal e deputado estadual); ou (ii) abrir um comitê para cada eleição, desde que tenha candidato (ou seja, comitês diferentes para a eleição ao Governo Estadual, ao Senado, à Câmara dos Deputados e às Assembléias Legislativas).

Para as eleições presidenciais, se apresentar candidato, o partido é obrigado a abrir um comitê nacional, sendo facultativa à legenda a abertura de comitês estaduais para a eleição presidencial $\left(\S 2^{\circ}\right)$. 
Cada partido é livre para designar quem participará dos comitês financeiros. Não havendo previsão no estatuto, fica a direção do partido livre para designar os membros dos comitês.

A Resolução TSE n. 22.715/08, em seu art. $6^{\circ}$, prevê que eles devem ser constituídos ao menos por duas pessoas, que serão o presidente e o tesoureiro. Porém, é faculdade do partido determinar o número de membros do comitê e quem serão os indicados.

Também dispõe a Resolução que a criação de comitê de coligação partidária é proibida (art. $6^{\circ}, \S 3^{\circ}$ ), além de o partido participante de coligação, mas sem candidato na eleição para prefeito ser desobrigado de criar comitê financeiro para a eleição majoritária $\left(\operatorname{art.} 6^{\circ}, \S 2^{\circ}\right)$.

Os comitês têm por atribuição (art. $7^{\circ}$ ), além de arrecadar e aplicar os recursos de campanha, distribuir aos candidatos os recibos eleitorais para as doações feitas por pessoas físicas e jurídicas; orientar os candidatos sobre a normatização do financiamento das campanhas e encaminhar à Justiça Eleitoral as prestações de contas, na forma dos arts. 28 e 29 da LE.

O pedido de registro do comitê financeiro à Justiça Eleitoral deve conter a ata da reunião que decidiu por sua constituição; a relação nominal dos membros, acompanhadas dos respectivos CPFs (Cadastro de Pessoa Física) e assinaturas; endereço e número de fac-símile para o recebimento de intimações e comunicados da Justiça Eleitoral.

A responsabilidade pela administração financeira da campanha é do candidato, conforme dispõe o art. 20 da LE. Ou seja, todos os recursos de campanha, desde as doações de pessoas físicas e jurídicas, recursos repassados pelos comitês (inclusive os provenientes do Fundo Partidário), ou recursos próprios ficam sob a guarida legal do candidato. Ele pode nomear pessoa de sua confiança, pessoas estas conhecidas na prática como "tesoureiros de campanha" para auxiliá-lo na administração. 
A veracidade das informações financeiras e contábeis da campanha também é de responsabilidade do candidato, mas se houve designação de um administrador/tesoureiro, deve este também assinas a prestação de contas, sendo ambos responsáveis solidários (art. 21, com redação dada pela Lei n. 11.300/06).

No campo penal, entretanto, deve-se demonstrar a responsabilidade por meio probatório de que o administrador também teve responsabilidade na eventual irregularidade. No âmbito extrapenal, entretanto, a responsabilidade é de todos aqueles que tiveram como trabalho na campanha a administração financeira dela, devendo todos estes assinar a prestação de contas.

Houve a mudança no texto do artigo pela Lei n. 11.300/06 (antes, era de responsabilidade exclusiva do candidato a veracidade das informações financeiras e contábeis nas prestações de contas de campanha) pelo fato de no escândalo do "mensalão", o tesoureiro do PT e da campanha de Luiz Inácio Lula da Silva à Presidência da República, Delúbio Soares, ter assumido publicamente na CPI dos Correios (comissão esta que investigou a denúncia do "mensalão" em 2005) que ele foi o único responsável por todas as irregularidades cometidas pelo partido na campanha, isentando o presidente Lula de qualquer responsabilidade (ele não teve conhecimento de nenhuma das irregularidades, segundo Delúbio). Ao assumir a responsabilidade pela arrecadação, administração e aplicação de "recursos não contabilizados" na campanha do presidente Lula de 2002 sozinho, afirmando que somente ele coordenou todo o esquema de “caixa 2" da campanha presidencial ${ }^{261}$, Delúbio, ao menos na esfera eleitoral, não pôde ser denunciado e indiciado, pois não havia previsão legal de eventual punição de administrador de campanha.

Joel Cândido, no entanto, critica a nova redação do art. 21, pois segundo ele o art. 22, inciso XIV da LI prevê que respondem por abuso do poder econômico todos (candidatos ou não, que tenham ou não assinado a prestação de contas apresentadas à Justiça Eleitoral) aqueles que "hajam contribuído para a prática do ato", sendo desnecessária a previsão contida no art. 21 da $\mathrm{LE}^{262}$.

\footnotetext{
${ }^{261}$ Cf. Augusto Nunes, A esperança estilhaçada: crônicas da crise que abalou o PT e o governo Lula. São Paulo: Planeta, 2005, p. 83.

${ }^{262}$ Cf. Joel Cândido, Direito eleitoral brasileiro, p. 440.
} 
As movimentações financeiras de campanha eleitoral devem todas passar pela conta bancária aberta pelo partido ou candidato para tal fim, sendo sua abertura obrigatória (art. 22, caput). O dispositivo tem o objetivo de facilitar o controle da administração financeira da campanha por parte da Justiça Eleitoral, principalmente pelo fato de os extratos bancários serem documentos que podem ajudar em um melhor controle das prestações de contas para que se veja a origem das receitas e das despesas.

Os bancos são obrigados a abrir as contas bancárias para as campanhas eleitorais em nome do candidato ou do comitê financeiro em até três dias da data do pedido de abertura, não restando ao banco a possibilidade de condicionar a abertura a um depósito mínimo ou à cobrança de taxas e/ou outras despesas para a manutenção da conta $\left(\S 1^{\circ}\right.$ do art. 22, com nova redação dada pela Lei n. 12.034/09).

Assim, não pode o banco recusar a abertura da conta bancária de campanha pelo fato de o candidato constar em listas de restrições cadastrais impeditivas de movimentação financeira ${ }^{263264}$, nem exigir que haja um depósito mínimo para que a conta tenha alguma quantia e nem mais (essa foi a novidade trazida pela Lei $\mathrm{n}$. 12.034/09) exigir o pagamento de taxas para qualquer serviço bancário ou despesa referente à manutenção desta conta.

Não há, entretanto, previsão de sanção para o banco que se recuse abrir a conta de campanha, cabendo ao candidato ou partido recorrer à Justiça Eleitoral, que provavelmente determinará ao banco a abertura da conta, sob pena de crime de desobediência (art. 347 do CE) ${ }^{265}$.

Para a abertura da conta bancária (art. 13 da Resolução TSE n. 22.715/08), são necessários os seguintes documentos: (i) requerimento de abertura de conta bancária

\footnotetext{
${ }^{263}$ Cf. Renato Ventura Ribeiro, Lei eleitoral comentada, p. 177.

${ }^{264}$ Conforme Carta-Circular-Bacen n. 3.320, de 4.6.2008, os bancos podem não fornecer talonário de cheques ao depositante (candidato) que figurar no Cadastro de Emitentes de Cheque sem Fundo, devendo a movimentação financeira ocorrer por meio magnético ou cheque avulso.

${ }^{265}$ Cf. Olivar Coneglian, Lei das eleições anotada, p. 150.
} 
eleitoral (Race), com modelo disponível no Anexo III da referida Resolução; e (ii) comprovante de inscrição no Cadastro Nacional de Pessoas Jurídicas para as eleições ${ }^{266}$.

Apesar de a abertura da conta ser obrigatória, há exceções legais a esta regra. Tanto nos municípios em que não haja agência bancária como naqueles que o eleitorado seja menor do que vinte mil pessoas o candidato não precisa abrir conta de campanha (art. 22, § $2^{\circ}$ ). Apesar de não haver a necessidade de abertura de conta nos casos ora expostos, deve-se, porém, manter a contabilização das receitas e despesas de campanha. As previsões legais que dispõem sobre as exceções à regra de abertura obrigatória de conta bancária para as campanhas são elogiadas por Carlos Velloso e Walber Agra, conforme trecho a seguir:

As exceções permitidas foram de extrema sensibilidade, tendo em vista que inexiste razoabilidade de se exigir o deslocamento para outras cidades para a abertura de conta bancária ou a obrigatoriedade de abri-las nos municípios em que o aporte financeiro para as campanhas é baixo ${ }^{267}$.

Interessante notar que a hipótese que dispensa a abertura de conta bancária no caso de não haver agência no Município não tem mais eficácia. $\mathrm{O}$ art. 12, parágrafo único da Resolução TSE n. 22.715/08, que disciplinou as eleições municipais de 2008, considera agência bancária para efeitos da LE os "postos de atendimento bancários e congêneres, bem como os correspondentes bancários contratados e registrados no Banco Central do Brasil”. Há, porém, um banco privado que tem agências ou postos de atendimento bancário em todos os municípios do país, deixando de ter a primeira hipótese do $\S 2^{\circ}$ do art. 22 razão de existir.

Novamente a Lei n. 11.300/06 inclui dispositivo na LE, desta vez o $\S 3^{\circ}$ do art. 22. Prevê o texto deste parágrafo que caso a campanha se utilize de recursos financeiros que não sejam movimentados por meio da conta bancária de campanha, deve sofrer as seguintes punições: (i) desaprovação da prestação de contas do candidato ou do partido;

\footnotetext{
${ }^{266}$ As contas bancárias eleitorais para as eleições de 2008 deveriam ser identificadas da seguinte forma, conforme determinação dos $\S \S 1^{\circ} \mathrm{e} 2^{\circ}$ do art. 13 da Resolução TSE n. 22.715/08: "Eleição 2008 - Comitê Financeiro (Município) - (UF) - (cargo eletivo) ou a expressão "único", seguida da sigla do partido", no caso de comitês, e "Eleição 2008 - (nome do candidato) - (cargo eletivo)", no caso de contas bancárias de candidatos.

${ }^{267}$ Carlos Mário da Silva Velloso e Walber de Moura Agra, Elementos de direito eleitoral, p. 224.
} 
e (ii) havendo abuso do poder econômico, cancelamento do registro de candidatura ou cassação do diploma, se este já tiver sido expedido.

O parágrafo em comento é nova tentativa de punir os candidatos que utilizem do "caixa dois" de campanha como forma de esconder recursos e gastos eleitorais, infringindo assim a igualdade de condições entre os postulantes.

Joel Cândido, entretanto, defende que a conduta descrita pelo texto legal como irregular é o "uso" de recursos não declarados. Portanto, se a campanha arrecadar irregularmente, mas não aplicar o dinheiro, não se configura a hipótese infracional contida no parágrafo, desde que o valor recebido paralelamente não seja de fonte vedada $^{268}$.

Ademais, afirma Cândido que o $\$ 3^{\circ}$, pelo menos em sua parte final, é inconstitucional, pois somente pode-se prever o cancelamento de registro ou a cassação do diploma de um candidato em sede de lei complementar, e não em lei ordinária. Porém, ressalta o autor que se a infração caracterizada como abuso do poder econômico tiver como base legal as hipóteses presentes na LI e não o $\S 3^{\circ}$ do art. 22 , poderá o candidato sofrer as sanções inicialmente citadas ${ }^{269}$.

A hipótese ora discutida não abrange tanto os candidatos que não são obrigados a abrir conta bancária de campanha $\left(\S 2^{\circ}\right)$ como também os gastos eleitorais realizados por eleitor (art. 27, com comentários adiante). No entanto, Renato Ventura Ribeiro defende que o candidato que não é obrigado a abrir conta, conforme $\S 2^{\circ}$, mas mesmo assim resolve abri-la; e em sua campanha há recursos e gastos que não passam por essa conta não deve ser punido, desde que ele faça a declaração desses recursos e gastos em sua prestação de $\operatorname{contas}^{270}$.

No caso de rejeição das contas por haver recursos movimentados nas campanhas sem passar pela conta bancária de campanha, a Justiça Eleitoral deve remeter cópia dos

\footnotetext{
${ }^{268}$ Cf. Joel J. Cândido, Direito eleitoral brasileiro, p. 442 e Ricardo Porto, Lei eleitoral anotada: Lei $n$. 9.504, de 30 de setembro de 1997, p. 48.

${ }^{269}$ Cf. Joel J. Cândido, Direito eleitoral brasileiro, p. 444.

${ }^{270}$ Cf. Renato Ventura Ribeiro, Lei eleitoral comentada, p. 178.
} 
autos processuais ao Ministério Público Eleitoral para a apresentação de AIJE por abuso do poder econômico, conforme determina o $§ 4^{\circ}$ da LE, incluído pela Lei n. 11.300/06.

A Lei n. 12.034/09 incluiu na LE o art. 22-A, que trata da inscrição de candidaturas e comitês financeiros no Cadastro Nacional de Pessoas Jurídicas (CNPJ).

O caput do art. 22-A faz menção à obrigatoriedade da inscrição no CNPJ de "candidatos e comitês financeiros". Esta possibilidade existia no ordenamento jurídico brasileiro desde a eleição de 2002, por meio da Instrução Normativa Conjunta SRF/TSE n. $183 / 02^{271}$. Apesar de um inicial estranhamento ao fato de o caput do art. 22-A obrigar candidatos a se inscreverem no CNPJ (afinal, tratam-se de pessoas físicas e não jurídicas), Denise Schlickmann explica os motivos dessa disposição, além de suas vantagens, conforme trecho a seguir:

A inscrição de candidatos e comitês financeiros no CNPJ teve por objetivo, única e exclusivamente, a abertura de contas bancárias para o registro da movimentação financeira de campanha eleitoral. Com o CNPJ, instituiu-se importante diferenciação entre o candidato e a pessoa física, dissociando-os e auxiliando a evitarf a confusão advinda da movimentação equivocada dos recursos de campanha eleitoral em contas de natureza particular, estabelecendo a norma o cancelamento dessas inscrições, de ofício, em 31.12.2002. Veja-se: não teve a instituição do CNPJ a finalidade de tornar exigíveis aos candidatos - até porque seria absolutamente incorreto - as obrigações instituídas para as pessoas jurídicas. (...) Tal inscrição teve - uma vez mais - por único e exclusivo objetivo a abertura de contas banc'rias de campanha eleitoral, identificando-as como contas referentes às eleições de 2002. Sobre esse aspecto, ressalte-se que a norma introduziu a exigência salutar de identificação dessas contas com a expressão 'ELEIÇÃO 2002 - CF ou CANDIDATO', diferenciado-as de contas de natureza particular ${ }^{272}$.

Recebido o pedido de registro de candidatura, deve a Justiça Eleitoral fornecer em até três dias úteis o número de registro no CNPJ (Art. 22-A, $\S 1^{\circ}$ ). Com o número do CNPJ em mãos e com sua respectiva conta bancária aberta, os candidatos e os comitês financeiros podem iniciar a administração dos recursos financeiros de campanha, sendo

\footnotetext{
${ }^{271}$ Para as eleições municipais de 2008, foi expedida a Instrução Normativa Conjunta RFB/TSE n. 838, de 18.4.2008.

${ }^{272}$ Denise Goulart Schlickmann, Financiamento de campanhas eleitorais, p. 95-96.
} 
permitidas a arrecadação e a aplicação dos recursos nas campanhas eleitorais (art. 22-A, $\left.\S 2^{\circ}\right)$.

\subsubsection{Doações: forma, limites, vedações e penas}

As doações feitas para as campanhas eleitorais podem vir de dois tipos de pessoas: as pessoas físicas (art. 23, caput) e as pessoas jurídicas (art. 81, caput).

Interessante notar que a previsão de doações advindas de pessoas jurídicas consta nas disposições transitórias da LE. Essa localização se deve ao fato de o art. 79 prever lei específica para disciplinar o "financiamento das campanhas eleitorais com recursos públicos". Isso ocorreu pelo fato de não haver acordo entre os partidos na época sobre as regras do financiamento público (a oposição ao então presidente Fernando Henrique Cardoso defendia o sistema público exclusivo), sendo o problema deixado para o futuro ${ }^{273}$.

Portanto, a vontade do legislador federal ao editar a Lei n. 9.504/97 era a de tornar o sistema normativo de financiamento das campanhas eleitorais no Brasil de caráter exclusivamente público, ficando assim os dispositivos que normatizam as doações de pessoas jurídicas localizadas nas disposições transitórias da lei (ou seja, assim que disciplinado o financiamento público, os ditames das doações das pessoas jurídicas seriam revogados). A possibilidade de doações por parte de pessoas físicas, no entanto, seria preservada ${ }^{274}$, configurando-se na verdade um sistema misto, e não exclusivamente público.

As pessoas jurídicas ${ }^{275}$ podem doar recursos para as campanhas eleitorais de seu interesse, não havendo limite ao número de campanhas beneficiadas nem qualquer filtro

\footnotetext{
${ }^{273}$ Cf. Adriano Soares da Costa, Instituições de direito eleitoral, p. 904-905.

${ }^{274}$ Cf. Renato Ventura Ribeiro, Lei eleitoral comentada, p. 449.

275 “A Art. 81. As doações e contribuições de pessoas jurídicas para campanhas eleitorais poderão ser feitas a partir do registro dos comitês financeiros dos partidos ou coligações.

$\S 1^{\circ}$ As doações e contribuições de que trata este artigo ficam limitadas a dois por cento do faturamento bruto do ano anterior à eleição.

$\S 2^{\circ}$ A doação de quantia acima do limite fixado neste artigo sujeita a pessoa jurídica ao pagamento de multa no valor de cinco a dez vezes a quantia em excesso.

$\S 3^{\circ}$ Sem prejuízo do disposto no parágrafo anterior, a pessoa jurídica que ultrapassar o limite fixado no $\S$ $1^{\circ}$ estará sujeita à proibição de participar de licitações públicas e de celebrar contratos com o Poder
} 
ideológico (as empresas podem doar para quaisquer partidos e candidatos, inclusive adversários em uma mesma eleição). $O$ texto do caput refere-se a "doações e contribuições", termos estes que devem ser entendidos como sinônimos ${ }^{276}$.

Porém, a LE impõe um limite de verba a ser doada para as campanhas eleitorais, que é de $2 \%$ do faturamento bruto da empresa auferido no ano anterior à eleição (art. 81, $\S 1^{\circ}$ ). Caso a empresa extrapole o limite, poderá arcar com o pagamento de multa no valor de 5 a 10 vezes ao valor doado em excesso, além de não poder celebrar contratos com o Poder Público, tampouco participar de procedimentos licitatórios por cinco anos $\left(\operatorname{art} .81, \S \S 2^{\circ}\right.$ e $\left.3^{\circ}\right)$.

Enfatiza a LE, em conformidade ao texto constitucional, a garantia da possibilidade da empresa supostamente infratora ter acesso à ampla defesa no processo judicial. Não há no texto legal, entretanto, clareza quanto ao marco inicial para a contagem desses cinco anos: pode-se interpretar que a contagem da punição inicia-se tanto a partir da prolação da sentença condenatória, data em que ocorreu a eleição ${ }^{277}$, do cometimento do ato irregular ou do trânsito em julgado da sentença ${ }^{278}$.

A Lei n. 12.034/09 inclui o $\S 4^{\circ}$ no art. 81 da LE, definindo o rito processual da ação de investigação judicial eleitoral previsto na LI como o adequado para a apuração de eventual irregularidade na doação de pessoas jurídicas que possam ensejar as punições acima citadas. A inclusão do $\S 4^{\circ}$ se deve ao fato de até então o rito processual a ser seguido ser o da representação eleitoral (art. 96 da LE) de caráter sumário, considerado incompatível principalmente em relação à natureza da sanção do $\S 3^{\text {o279 }}$. O rito da AIJE, ao contrário, prevê prazos mais longos para a defesa e eventual recurso, além de oitiva de testemunhas e dilação probatória.

Público pelo período de cinco anos, por determinação da Justiça Eleitoral, em processo no qual seja assegurada ampla defesa.

$\S 4^{\circ}$ As representações propostas objetivando a aplicação das sanções previstas nos $\S \S 2^{\circ}$ e $3^{\circ}$ observarão o rito previsto no art. 22 da Lei Complementar $\mathrm{n}^{\circ} 64$, de 18 de maio de 1990, e o prazo de recurso contra as decisões proferidas com base neste artigo será de 3 (três) dias, a contar da data da publicação do julgamento no Diário Oficial".

${ }_{276}$ Cf. Olivar Coneglian, Lei das eleições comentada, p. 376.

${ }^{277}$ Cf. Olivar Coneglian, Lei das eleições comentada, p. 377.

${ }^{278}$ Cf. Joel J. Cândido, Direito eleitoral brasileiro, p. 582.

${ }^{279}$ Cf. Joel J. Cândido, Direito eleitoral brasileiro, p. 582. 
Quanto às pessoas físicas, as doações são permitidas conforme disposto no art. 23 da LE. As pessoas físicas também não sofrem qualquer limitação quanto ao número de candidaturas beneficiadas com suas doações, nem mesmo qualquer filtro ideológico.

O limite disposto na legislação é monetário: a pessoa física pode doar para as campanhas eleitorais de sua preferência o valor de até $10 \%$ seus rendimentos brutos auferidos no ano anterior à eleição (art. $23, \S 1^{\circ}$, inciso I). Já os candidatos que utilizam recursos próprios nas suas campanhas têm como limite o valor máximo de gastos estabelecido pelo seu partido, conforme prevê o art. 18 da LE (art. $23, \S 1^{\circ}$, inciso II).

Neste limite imposto pela legislação à utilização de recursos próprios repousa críticas e dúvidas entre os estudiosos do tema. Alguns crêem que o candidato que usa recursos próprios não está submetido ao limite de $10 \%$ de seus rendimentos brutos do inciso I, já que em algumas eleições com menor necessidade de recursos os candidatos bancam suas campanhas sozinhos, sem a necessidade de doadores externos ${ }^{280}$. O entendimento diametralmente contrário se justifica ante o fato de a lei não fazer diferença entre a pessoa física comum e a pessoa física candidata (se houvesse distinção, haveria quebra do princípio constitucional da isonomia), além de se evitar que o candidato depene seu patrimônio com o escopo de evitar o pagamento de credores ou até em proteção aos seus próprios familiares ${ }^{281}$.

No entanto, a inclusão do $\S 7^{\circ}$ no art. 23 , por meio da Lei n. $12.034 / 09$ pode ter esclarecido a questão. Seu texto prevê que o limite do inciso I (máximo de $10 \%$ do rendimento bruto auferido no ano anterior) "não se aplica a doações estimáveis em dinheiro relativas à utilização de bens móveis ou imóveis de propriedade do doador, desde que o valor da doação não ultrapasse R \$ 50.000,00”.

Assim sendo, percebe-se ao analisar o texto do $\S 7^{\circ}$ que o candidato deve respeitar o limite de $10 \%$ de seu rendimento bruto ao usar recursos próprios em sua campanha. No entanto, este limite não precisa ser respeitado no único caso de utilização

\footnotetext{
${ }^{280}$ Cf. Olivar Coneglian, Lei das eleições comentada, p. 154-155 e Adriano Soares da Costa, Instituições de direito eleitoral, p. 747.

${ }^{281}$ Cf. Renato Ventura Ribeiro, Lei eleitoral comentada, p. 183 e Joel J. Cândido, Direito eleitoral brasileiro, p. 447.
} 
em sua própria campanha de bem móvel ou imóvel de sua propriedade, desde que essa utilização não seja estimada em valor acima de $\mathrm{R} \$ 50.000,00$.

Esta previsão, apesar de esclarecer a dúvida acima citada, é uma porta para o cometimento de atos de abuso de poder econômico, eis que cabe ao próprio candidato estabelecer o valor da doação referente ao uso desses bens móveis ou imóveis, ensejando assim a possibilidade de os candidatos subvalorizarem sua própria doação, havendo mais espaço para doações de terceiro ou para novas doações de bens de sua propriedade para sua campanha.

A Lei n. 12. 034/09 mudou a redação do $\S 2^{\circ}$ do art. 23, mantendo a necessidade de expedição de recibo eleitoral para cada doação ${ }^{282}$ (independentemente da origem, pessoa física ou jurídica) e trouxe a possibilidade de se fazer doações pela Internet, devendo ser emitido também recibo desta doação eletronicamente.

Os recibos, segundo definição legal contida do art. $3^{\circ}$ da Resolução TSE $n$. 22.715/08, são "documentos oficiais que viabilizem e tornam legítima a arrecadação de recursos para a campanha", sendo "imprescindíveis seja qual for a natureza do recurso, ainda que do próprio candidato".

A confecção e a distribuição aos comitês financeiros são de responsabilidade dos diretórios nacionais dos partidos políticos, cabendo aos comitês repassarem os recibos aos candidatos antes do início do período de arrecadação de recursos de campanha (art. $4^{\text {o }}$, caput, da Resolução TSE n. 22.715/08)

Caso haja infração aos limites dispostos no art. 23 , seu $\S 3^{\circ}$ prevê multa ao doador pessoa física infrator no valor de cinco a dez vezes o valor em excesso, tal como no caso de pessoas jurídicas ${ }^{283}$.

\footnotetext{
${ }^{282}$ O TSE decidiu, no Agravo n. 6.265 (julgado em 01.12.2005, DJ 03.02.2006, Rel. Min. Humberto Gomes de Barros), que a ausência dos recibos eleitorais na prestação de contas constitui irregularidade insanável.

${ }^{283}$ A Resolução TSE n. 22.715/08 prevê, em seu art. 17, § 5 ${ }^{\circ}$, a possibilidade da Justiça Eleitoral solicitar informações a quaisquer órgãos que por ventura possam colaborar na apuração do possível desrespeito aos limites de doação para as pessoas físicas ou jurídicas, excluídas as hipóteses de quebra do sigilo bancário ou fiscal.
} 
O caput do art. 23 prevê que as doações podem ser feitas em dinheiro ou em bens estimáveis em dinheiro, como por exemplo, a cessão de um carro ou uma casa para a campanha eleitoral. A doação em bem estimável deve ser convertida em dinheiro, para efeito na prestação de contas a ser apresentada à Justiça Eleitoral.

As doações em dinheiro, no entanto, jamais podem ser feitas fora da conta bancária de campanha (ou seja, nunca uma campanha pode receber doação em dinheiro vivo, apesar de tal proibição ser obviamente bastante difícil de ser controlada). Assim, recursos financeiros devem ser doados por meio de cheques cruzados e nominais, transferência eletrônica de depósitos (hipótese incluída pela Lei n. 11.300/06), depósito bancário de dinheiro em espécie devidamente identificado (incluída pela Lei $\mathrm{n}$. 11.300/06) e por meio de doações pela Internet em mecanismo a ser disponibilizado na página eletrônica do candidato, com a identificação do doador e a emissão do recibo eleitoral (em repetição ao previsto no $\S 2^{\circ}$ deste artigo; hipótese incluída pela Lei $\mathrm{n}$. $12.034 / 09)$.

Essas doações por meio da página do candidato na Internet podem ser feitas de duas formas: por cartão de crédito e também por meio de emissão de boleto bancário. $\mathrm{O}$ TSE ainda não regulamentou a prática, devendo fazê-lo até 5 de março de 2010, data limite para a apresentação das Resoluções que regulamentarão as eleições gerais de 2010. Havendo fraudes ou erros cometidos nas doações pela Internet ocorridos em conhecimento dos candidatos, partidos ou coligações, os mesmos não terão qualquer responsabilidade e esta ocorrência não ensejará a rejeição da prestação de contas apresentada à Justiça Eleitoral (art. 23, § 6º incluído pela Lei n. 12.034/09).

O texto, porém, não faz menção à figura do administrador de campanha, que divide a responsabilidade com o candidato pela veracidade das informações financeiras e contábeis da campanha (art. 21 da LE), restando assim a dúvida: se restar provado nos autos que o administrador da campanha teve conhecimento da fraude ou do erro cometido em doação pela Internet, ele responde pela irregularidade? Diante do fato de que há na lei a previsão de responsabilidade solidária entre o administrador e o candidato na administração financeira da campanha - devendo inclusive a prestação de contas ser assinada por ambos - o candidato também não deveria ser responsabilizado? 
São vedadas também aos candidatos as doações em dinheiro, como também as de prêmios, troféus e quaisquer tipos de ajudas feitas por candidatos a pessoas físicas e jurídicas durante o período eleitoral (art. 23, $§ 5^{\text {o284 }}$, incluído pela Lei n. 11.300/06).

A inclusão desta vedação como um parágrafo do artigo da LE que disciplina as doações aos candidatos é criticada, já que se trata de modalidade de gasto ou propaganda eleitoral, além de irregularidade que tem como objetivo beneficiar eleitor ou grupo de eleitor em troca de seus votos ${ }^{285}$.

Deve-se atentar ao fato de que há vedação à doação feita somente por candidato, não havendo previsão legal contra a eventual doação feita por partido, coligação ou até mesmo a outro eleitor em favor de candidato de sua preferência (previsão contida no art. 27 da LE).

Joel Cândido, no entanto, afirma que ao contrário da conduta de compra de votos prevista no art. 41-A da $\mathrm{LE}^{286}$, em que o candidato corrompe o eleitor em troca de seu voto, na previsão do $\S 5^{\circ}$ do art. 23 não há necessariamente nesses tipos de doação a finalidade de obter o voto dos beneficiados, havendo, portanto, infração de abuso do poder econômico e não corrupção eleitoral ${ }^{287}$.

$\mathrm{O}$ autor critica duramente o fato de a irregularidade prevista no $\S 5^{\circ}$ do art. $23-$ de caráter menos grave que a compra de votos prevista no art. 41-A - ter como possível sanção condenação mais grave ao infrator que a prevista no artigo que trata da compra de votos.

A conduta do $\S 5^{\circ}$ do art. 23 pode ensejar ao infrator não só a cassação do registro de candidatura ou do diploma (se este já tiver sido expedido), mas também a

\footnotetext{
284 “\$ $5^{\circ}$ Ficam vedadas quaisquer doações em dinheiro, bem como de troféus, prêmios, ajudas de qualquer espécie feitas por candidato, entre o registro e a eleição, a pessoas físicas ou jurídicas".

${ }^{285}$ Cf. Renato Ventura Ribeiro, Lei eleitoral comentada, p. 185.

286 “Art. 41-A. Ressalvado o disposto no art. 26 e seus incisos, constitui captação de sufrágio, vedada por esta Lei, o candidato doar, oferecer, prometer, ou entregar, ao eleitor, com o fim de obter-lhe o voto, bem ou vantagem pessoal de qualquer natureza, inclusive emprego ou função pública, desde o registro da candidatura até o dia da eleição, inclusive, sob pena de multa de mil a cinqüenta mil Ufir, e cassação do registro ou do diploma, observado o procedimento previsto no art. 22 da Lei Complementar $\mathrm{n}^{\circ}$ 64, de 18 de maio de 1990".

${ }^{287}$ Cf. Joel J. Cândido, Direito eleitoral brasileiro, p. 448.
} 
possibilidade de declaração de inelegibilidade por três anos ao candidato infrator, conforme art. $1^{\circ}$, inciso I, alínea "d”, que prevê esta sanção em caso de abuso do poder econômico. $\mathrm{O}$ art. 41-A, entretanto, não prevê a decretação de inelegibilidade, mas tão somente a cassação do registro ou do diploma. Na visão de Joel Cândido, o advento do $\S 5^{\circ}$ ao art. 23 trará um "esvaziamento" do art. 41-A, pois a apuração dessas irregularidades prevê o mesmo rito processual (o da AIJE), mas poderá ter consequiências judiciais diferentes aos seus infratores. Provavelmente, o propositor de eventual AIJE procurará processar o candidato infrator por cometimento da conduta do art. $23, \S 5^{\circ}$, e não pelo art. $41-\mathrm{A}^{288}$.

Além das doações provenientes de pessoas físicas e jurídicas e dos recursos próprios do candidato, são fontes de receitas das campanhas eleitorais, conforme disposto no art. 15 da Resolução TSE n. 22.715/08 as (i) doações de outros candidatos, comitês financeiros ou partidos políticos, ou seja, pode haver transferência de montantes financeiros entre quaisquer candidatos, partidos e comitês, no intuito de ajudar financeiramente campanha com dificuldades financeiras; (ii) os repasses de recursos provenientes do Fundo Partidário (a ser analisado no item 3.2.2); e (iii) receita decorrente da comercialização de bens ou da realização de eventos. Todas essas receitas também são hipóteses de expedição compulsória de recibo eleitoral.

A comercialização de bens ou a realização de eventos com o escopo de arrecadação de recursos para campanhas eleitorais deve ser comunicada previamente pelo candidato ou comitê à Justiça Eleitoral (prazo de cinco dias antes do ato), já que a Justiça pode determinar diligência para fiscalização do ato. (art. 20, inciso I da Resolução TSE n. 22.715/08), devendo ser tudo comprovado na prestação de contas (art. 20, inciso II), além de serem considerados como doações para os efeitos financeirocontábeis da campanha eleitoral (art. 20, $\S 1^{\circ}$ ). Deve todo o montante arrecadado ser depositado na conta bancária de campanha para a sua posterior aplicação (art. 20, § $2^{\circ}$ ).

A LE também prevê extenso rol de pessoas jurídicas que não podem doar recursos a nenhuma campanha eleitoral, rol este de caráter taxativo, e não

\footnotetext{
${ }^{288}$ Cf. Joel J. Cândido, Direito eleitoral brasileiro, p. 449-450 e Ricardo Porto, Lei eleitoral anotada: Lei n. 9.504, de 30 de setembro de 1997, p. 50.
} 
exemplificativo $^{289}$, por haver restrições às doações para as campanhas eleitorais. A lei prevê estas vedações, segundo Carlos Velloso e Walber Agra, pelo fato de essas entidades serem capazes, ante seu tamanho e importância, de influenciar a eleição ao ponto de desequilibrá-la por meio de eventuais doações, além também de impedir que entidades públicas ou entidades que possuam laços com o poder público possam exercer suas funções com desvio de finalidade ${ }^{290}$.

As doações vedadas são as realizadas tanto em dinheiro como em estimável em dinheiro, inclusive por meio de qualquer tipo de publicidade. Permite-se, porém, que os partidos ou os candidatos celebrem contratos de prestação de serviços com estas pessoas jurídicas, conforme trecho explicativo a seguir:

Note-se, entretanto, que o artigo somente veda a doação de dinheiro ou em bens e serviços estimáveis em dinheiro das entidades nele referidas. No entanto, é permitida a celebração, pelos partidos e candidatos, de contratos de prestação de serviços, fornecimento ou empréstimo de bens, móveis e imóveis, com concessionários ou permissionários de serviço público, entidade de classe ou sindical ou pessoa jurídica sem fins lucrativos que receba recursos do exterior, desde que haja pagamentos a preços de mercado, como aluguel de imóveis para eventos, transporte e até propaganda em imprensa escrita ${ }^{291}$.

Deve estar atenta a Justiça Eleitoral para esta possibilidade, já que os candidatos, em conluio com a entidade privada, podem subvalorizar o contrato, havendo assim espécie de doação em estimável cuja fonte é proibida de doar às campanhas eleitorais.

As hipóteses de doadores vedados previstas nos incisos do art. 24 da LE podem ser divididas em três tipos, quais sejam: (i) doadores que tenham relações com entidades estrangeiras; (ii) doadores que recebem recursos públicos ou que tenham estreitos laços com o Poder Público; e (iii) entidades que não tenham como objetivo social primordial a política ou as eleições.

Em respeito ao ditame constitucional da preservação da soberania nacional, a LE veda a doação para as campanhas eleitorais de entidades e governos estrangeiros (art.

\footnotetext{
${ }^{289}$ Cf. Olivar Coneglian, Lei das eleições comentadas, p. 158; Joel J. Cândido, Direito eleitoral brasileiro, p. 451 e Renato Ventura Ribeiro, Lei eleitoral comentada, p. 187.

${ }^{290}$ Cf. Carlos Mário da Silva Velloso e Walber de Moura Agra, Elementos de direito eleitoral, p. 228.

${ }^{291}$ Renato Ventura Ribeiro, Lei eleitoral comentada, p. 187.
} 
24, inciso I) e de pessoas jurídicas sem fins lucrativos que recebam recursos do exterior (inciso VII).

Também são vedadas as doações de entidades que recebam recursos públicos para sua administração e sobrevivência, entre elas os órgãos da administração pública direta ou indireta (inciso II); fundações mantidas com recursos públicos, independentemente de serem pessoas jurídicas de direito público ou privado (inciso II); entidade de direito privado que receba, na condição de beneficiária, contribuição compulsória em virtude de disposição legal (inciso IV, caso do Sesc, Senac e do Sesi); entidades de classe e sindicatos (de caráter patronal ou de empregados, assim como as federações ou centrais sindicais - inciso VI); e organizações não-governamentais que recebam recursos públicos (inciso X) ${ }^{292}$.

Estas organizações não podem doar recursos para nenhuma campanha eleitoral por receberem quantias públicas para sua administração de sobrevivência, em respeito aos princípios constitucionais da impessoalidade, de moralidade administrativa e da igualdade de oportunidade entre os candidatos. Se pudessem doar recursos (mesmo que de origem privada), não haveria como saber se os recursos doados tinham originalmente caráter público ou privado.

Incluem-se na lista das entidades vedadas de doarem recursos às campanhas eleitorais por terem estreitos laços com o Poder Público as concessionárias ou permissionárias de serviço público (inciso III); as entidades de utilidade pública (inciso V); e as organizações da sociedade civil de interesse público (inciso XI).

Estas entidades não necessariamente recebem recursos públicos, mas seus vínculos com o Poder Público podem acarretar distorções no que toca eventual permissão de doações às campanhas eleitorais.

As concessionárias ou permissionárias, por exemplo, têm seu trabalho fiscalizado pelo Poder Público, podendo os contratos administrativos celebrados serem

\footnotetext{
${ }^{292}$ A Resolução TSE n. 22.715/08, em seu art. 16, inciso XIII, prevê vedação à possibilidade de cartórios de serviços notariais e de registro doarem recursos às campanhas eleitorais. Esta previsão há flagrante desrespeito ao princípio constitucional da legalidade, eis que somente lei pode definir as possibilidades de vedações de doações às campanhas, e não Resolução, norma infralegal.
} 
rescindidos unilateralmente pela Administração Pública. A vedação contida do art. 24, inciso III protege tanto as próprias concessionárias ou permissionárias de eventual desmando por parte da Administração Pública como impede a possibilidade de elas doarem recursos para obter benefícios futuros ${ }^{293}$.

Já as entidades de utilidade pública podem gozar de benesses fiscais, além de ganhar tal status por meio de discussão no respectivo Legislativo. Estes fatos poderiam também ensejar relações entre candidatos e entidades de caráter obscuro, cada um visando obter vantagens graças a esse relacionamento.

Por fim, há também a vedação de doação para as campanhas eleitorais de entidades que não tenham como fim social a política ou as eleições: tratam-se das entidades beneficentes e religiosas (inciso VIII, incluído pela Lei n. 11.300/06) e das entidades esportivas (inciso IX, incluído pela Lei n. 11.300/06 e com redação alterada pela Lei n. 12.034/09).

As entidades beneficentes e religiosas estão no rol das pessoas que não podem doar recursos para nenhuma campanha eleitoral pelo fato de serem beneficiadas no âmbito tributário $^{294}$. Ademais, segundo Joel Cândido, tratou-se de inclusão casuística, já que a verdadeira intenção do legislador foi a de dificultar a candidatura de religiosos, "cujas bancadas nas Casas Legislativas aumentam a cada eleição". O autor não encontra justificativa plausível para a inclusão desta hipótese, já que o eixo do artigo é evitar as doações de entidades estrangeiras ou de entidades que recebam recursos públicos ou que tenham fortes vínculos com o Poder Público, o que não é o caso das entidades beneficentes e religiosas ${ }^{295}$.

Hoje, com a redação dada pela Lei n. 12.034/09, todas as entidades esportivas estão vedadas de doar recursos para qualquer campanha eleitoral. Após a Lei n. 11.300/06, estavam vedadas as doações com origem de entidades esportivas que recebessem recursos públicos. Para Joel Cândido, a inclusão dessa hipótese de vedação tem a mesma justificativa da anteriormente debatida: evitar o crescimento do número de

\footnotetext{
${ }^{293}$ Cf. Renato Ventura Ribeiro, Lei eleitoral comentada, p. 190.

${ }^{294}$ Cf. Renato Ventura Ribeiro, Lei eleitoral comentada, p. 191.

${ }^{295}$ Cf. Joel J. Cândido, Direito eleitoral brasileiro, p. 452-453.
} 
pessoas relacionadas à atividade profissional esportiva nos Legislativos, em especial a famosa "bancada da bola", em que ex-jogadores e ex-dirigentes esportivos conseguem eleger-se para lutar pelos interesses de parte dos atores do cenário esportivo brasileiro $^{296}$.

Por fim, foi incluído pela Lei n. 12.034/09 no art. 24 o parágrafo único, que prevê a possibilidade de as cooperativas realizarem doações às campanhas eleitorais, desde que: (i) não haja entre os cooperados concessionários ou permissionários de serviços públicos; e (ii) desde que as cooperativas não recebam recursos públicos.

Critica-se este artigo e seu respectivo rol principalmente pelo fato de não ter sido incluída a hipótese de vedação de doações de pessoas jurídicas que tenham celebrado contratos com o Poder Público, como empreiteiras e agências de publicidade ${ }^{297}$.

Não se discute aqui o fato de uma empresa ter interesse na eleição de um candidato pelo fato de ele, por exemplo, propor programas econômicos que incentivem sua produção. Mas ao assumir tal relação com a Administração Pública por meio da celebração de um contrato, pode-se inferir que o contrato foi assinado pelo fato de a empresa ter ajudado a campanha eleitoral do candidato ora eleito ou até na promessa de futuro auxílio à campanha de reeleição.

Adriano Soares da Costa inclusive classifica o rol do art. 24 como oportunista, fruto da "vivacidade" do legislador, ao apontar que paradoxalmente, uma empresa contratada pelo Poder Público pode doar recursos ao chefe do seu "cliente", mas ao mesmo tempo um sindicato que tenha candidatos ligados ao seu ideário e aos seus anseios não pode efetuar doações ${ }^{298}$.

Além das sanções pecuniárias previstas aos doadores infratores, há também previsão de pena para o partido político que descumprir as normas referentes à arrecadação e à aplicação de recursos nas campanhas eleitorais, conforme art. 25 da LE.

\footnotetext{
${ }^{296}$ Cf. Joel J. Cândido, Direito eleitoral brasileiro, p. 452.

${ }^{297}$ Cf. Renato Ventura Ribeiro, Lei eleitoral comentada, p. 191.

${ }^{298}$ Cf. Adriano Soares da Costa, Instituições de direito eleitoral, p. 749.
} 
Sua localização na lei é criticada, pois se refere a todo o sistema de arrecadação e aplicação dos recursos nas campanhas eleitorais, devendo vir após os artigos que tratam dos gastos eleitorais ${ }^{299}$.

Os partidos políticos infratores terão sua respectiva quota do Fundo Partidário suspensa no ano seguinte ao do trânsito em julgado da ação que apurou tal irregularidade. Já os candidatos infratores ou beneficiados por eventuais infrações poderão também responder por prática de abuso do poder econômico.

Como há no texto o termo "beneficiados", há a possibilidade de se punir o candidato que não tivera conhecimento ou mesmo participado do cometimento da irregularidade ${ }^{300}$.

A Lei n. 12.034/09 incluiu o parágrafo único no art. 25 da LE, determinando que “a sanção de suspensão do repasse de novas quotas do Fundo Partidário, por desaprovação total ou parcial da prestação de contas do candidato, deverá ser aplicada de forma proporcional e razoável, pelo período de 1 (um) mês a 12 (doze) meses, ou por meio do desconto, do valor a ser repassado, na importância apontada como irregular, não podendo ser aplicada a sanção de suspensão, caso a prestação de contas não seja julgada, pelo juízo ou tribunal competente, após 5 (cinco) anos de sua apresentação.”

Note-se que o caput do art. 25 não tem qualquer menção a uma possível desaprovação, total ou parcial, da prestação de contas do candidato, mas sim do cometimento de irregularidades na arrecadação ou aplicação de recursos na campanha eleitoral. A prestação de contas é a etapa financeira seguinte à campanha eleitoral, tanto é que foi merecedor de capítulo a parte na LE.

Ademais, mesmo que se entenda que o texto do parágrafo único se refira ao art. 25, caput, percebe-se que se criou dispositivo que pode ensejar um incentivo legal ao cometimento de irregularidades, já que cabe somente ao juiz, respeitando-se os princípios da proporcionalidade e da razoabilidade: (i) aplicar pena de um a doze meses

\footnotetext{
${ }^{299}$ Cf. Renato Ventura Ribeiro, Lei eleitoral comentada, p. 192.

${ }^{300}$ Olivar Coneglian tem entendimento contrário. Afirma o autor que é necessário provar a participação do candidato para que ele possa sofrer as penas previstas em caso de abuso do poder econômico (Cf. Olivar Coneglian, Lei das eleições comentadas, p. 164).
} 
de suspensão da quota do Fundo Partidário; ou (ii) por meio de desconto, do valor a ser repassado, na importância apontada como irregular.

Portanto, a pena que pelo texto do "caput" do art. 25 era de suspensão da quota do Fundo Partidário por um ano hoje pode ser aplicada por apenas um mês. Além disso, pode o juiz arbitrar a pena de desconto nesta quota de apenas o valor tido como irregular. Ademais, prevê também a prescrição da pena em cinco anos caso não haja decisão final da Justiça Eleitoral, o que pode estimular os partidos a apresentarem recursos visando atingir o prazo prescricional.

O prazo final para a arrecadação de recursos para as campanhas eleitorais é o dia da eleição (art. 21, caput, da Resolução TSE n. 22.715/08). Porém, há uma exceção: havendo obrigações já contraídas e ainda não pagas, permite-se a arrecadação após esse prazo para seu cumprimento (art. $21, \S 1^{\circ}$ ), devendo ser pagas até a data da apresentação da prestação de contas à Justiça Eleitoral (o caso de não pagamento neste prazo será estudado no item 3.1.4).

\subsubsection{Gastos eleitorais}

A LE prevê dois tipos de gastos nas campanhas eleitorais, quais sejam: os gastos feitos pelo candidato e gastos feitos por eleitor em favor de candidato de sua preferência.

O art. 26 da LE e seus incisos trazem extenso rol de gastos eleitorais. Senão, vejamos:

Art. 26. São considerados gastos eleitorais, sujeitos a registro e aos limites fixados nesta Lei:

I - confecção de material impresso de qualquer natureza e tamanho;

II - propaganda e publicidade direta ou indireta, por qualquer meio de divulgação, destinada a conquistar votos;

III - aluguel de locais para a promoção de atos de campanha eleitoral;

IV - despesas com transporte ou deslocamento de candidato e de pessoal a serviço das candidaturas;

V - correspondência e despesas postais; 
VI - despesas de instalação, organização e funcionamento de Comitês e serviços necessários às eleições;

VII - remuneração ou gratificação de qualquer espécie a pessoal que preste serviços às candidaturas ou aos comitês eleitorais;

VIII - montagem e operação de carros de som, de propaganda e assemelhados;

IX - a realização de comícios ou eventos destinados à promoção de candidatura;

$\mathrm{X}$ - produção de programas de rádio, televisão ou vídeo, inclusive os destinados à propaganda gratuita;

XII - realização de pesquisas ou testes pré-eleitorais;

XIV - aluguel de bens particulares para veiculação, por qualquer meio, de propaganda eleitoral;

XV - custos com a criação e inclusão de sítios na Internet;

XVI - multas aplicadas aos partidos ou candidatos por infração do disposto na legislação eleitoral.

XVII - produção de jingles, vinhetas e slogans para propaganda eleitoral.

O caput do art. 26 da LE foi alterado pela Lei n. 11.300/06, que retirou o termo "dentre outros". Com a retirada do termo, o rol, que era considerado exemplificativo, abrindo a possibilidade de as campanhas terem outros tipos de despesa, passou a ser taxativo. Corroboram com essa opinião, entre outros, Renato Ventura Ribeiro ${ }^{301}$ e Joel Cândido $^{302303}$. Olivar Coneglian, Carlos Velloso e Walber Agra, porém, discordam, já que nos incisos há trechos vagos como gastos "de qualquer natureza" ou "por qualquer meio" 304 ., além do fato de surgir com o passar do tempo novas necessidades nas campanhas, o que pode gerar a necessidade de se mudar constantemente a legislação ${ }^{305}$.

Denise Schlickmann ressalta que além da retirada do tempo citado, houve também a retirada de algumas hipóteses de gastos, acentuando assim a taxatividade do rol, pois se ainda fosse o rol exemplificativo, não haveria nenhum efeito legal a retirada dos incisos XI e XII, que previam como gastos eleitorais o pagamento de cachê a artistas ou animadores de eventos e a confecção, aquisição e distribuição de brindes de

\footnotetext{
${ }^{301}$ Cf. Renato Ventura Ribeiro, Lei eleitoral comentada, p. 197.

${ }^{302}$ Cf. Joel J. Cândido, Direito eleitoral brasileiro, p. 456.

${ }^{303}$ A Resolução TSE n. 22.715/08, porém, dispõe em seu art. 22, inciso XV que as doações feitas a outros candidatos ou comitês financeiros sejam considerados gastos eleitorais.

${ }^{304}$ Cf. Olivar Coneglian, Lei das eleições comentada, p. 166.

${ }^{305}$ Cf. Carlos Mário da Silva Velloso e Walber de Moura Agra, Elementos de direito eleitoral, p. 228.
} 
campanha em geral $^{306}$. Esse rol tem também a finalidade de definir os gastos eleitorais para facilitar a contabilização dos partidos e das campanhas nas prestações de contas a serem apresentadas à Justiça Eleitoral.

A mudança perpetrada pela Lei n. 11.300/06 tem o intuito de diminuir os custos de campanha, considerados um dos males do cenário político brasileiro, conforme já estudado no item 2.1.4.1. Ademais, tanto os "showmícios" - comícios em que os políticos apresentavam suas propostas, porém recheados de artistas e/ou animadores que faziam apresentação de caráter unicamente artístico e não político, como os brindes de campanha foram retirados do ordenamento jurídico brasileiro por serem considerados gastos que beneficiavam os candidatos com forte poder econômico.

Renato Ventura Ribeiro reconhece que pode haver diminuição da influência negativa do poder econômico com as mudanças feitas pela Lei n. 11.300/06. No entanto, afirma o autor que haverá maior dificuldade de os candidatos, principalmente os menos conhecidos pelo eleitorado, divulgarem suas candidaturas, eis que os brindes serviam como meio barato e fácil de exposição, por exemplo, do seu respectivo número de registro para ser votado na urna eletrônica ${ }^{307}$.

O primeiro dos gastos eleitorais permitidos é a confecção de material impresso, como santinhos, jornais, cartazes e faixas. A Resolução TSE n. 22.715/08, em seu art. 22, determinou que de todas as propagandas impressas de campanha devem compulsoriamente conter o CNPJ ou o CPF do responsável pela confecção do impresso, e a respectiva tiragem. $\mathrm{O}$ dispositivo tem como objetivo detectar a origem do material impresso, facilitando assim o controle dos gastos de campanha pela Justiça Eleitoral ${ }^{308}$.

Entre outros gastos com propaganda, estão as hipóteses elencadas nos incisos II, na qual se incluem gastos com marqueteiro e agências de marketing, por exemplo; correspondência e despesas postais (inciso V), carros de som (inciso VIII), comícios ou outros eventos de propagação da candidatura (inciso IX); produção de programas para o horário eleitoral gratuito no rádio ou na televisão (inciso X); aluguel de bem particular

\footnotetext{
${ }^{306}$ Cf. Denise Goulart Schlickmann, Financiamento de campanhas eleitorais, p. 160-161.

${ }^{307}$ Cf. Renato Ventura Ribeiro, Lei eleitoral comentada, p. 197.

${ }^{308}$ Cf. Denise Goulart Schlickmann, Financiamento de campanhas eleitorais, p. 163.
} 
para a veiculação de propaganda, como muros para a pintura de propaganda eleitoral (inciso XIV), criação e manutenção de sítios na Internet (inciso XV) e produções de jingles, vinhetas e slogans para propaganda eleitoral (inciso XVII).

Este último inciso foi incluído pela Lei n. 11.300/06, porém de forma desnecessária, já que este tipo de gasto poderia ser incluído tanto na hipótese do inciso II como também na do inciso X. Quanto aos comícios, não restou vedada a participação de artistas que tenha simpatia pela candidatura; o que se vedou foi a apresentação artística de qualquer tipo: música, dança, artística, humorística, dentre outras ${ }^{309}$.

Há também a previsão de gastos referentes à infra-estrutura da campanha, quais sejam: aluguel de local para ato de campanha (inciso III); despesas com transporte do candidato ou do pessoal de campanha (inciso IV); despesas com comitês e serviços necessários às eleições (inciso VI); e pagamento de pessoal de campanha (inciso VII).

Os locais alugados para ato de campanha (inciso II) pode ser salões de festa, auditórios, terrenos para a realização de comícios, entre outros. Renato Ventura Ribeiro rememora que se o bem foi cedido gratuitamente, deve ser declarado na prestação de contas como doação estimável em dinheiro ${ }^{310}$.

Quanto ao pagamento do pessoal, encaixa-se como gasto eleitoral a remuneração pelo seu trabalho, eis que não há vínculo empregatício entre o candidato-empregador e o funcionário-empregado (art. 100 da LE). No entendimento de Renato Ventura Ribeiro, portanto, a candidatura não deve qualquer tipo de encargos trabalhista. $\mathrm{O}$ autor assevera que a disposição guarda coerência com as normas de financiamento das campanhas eleitorais, eis que se houver uma reclamação trabalhista contra o candidato, a ação só teria seu valor monetário definido com a ocorrência do trânsito em julgado, o que impede a aferição do respeito ou não do limite de gastos imposto pela legislação eleitoral, restando pendente o julgamento das contas ${ }^{311}$.

\footnotetext{
${ }^{309}$ Cf. Renato Ventura Ribeiro, Lei eleitoral comentada, p. 199.

${ }^{310}$ Cf. Renato Ventura Ribeiro, Lei eleitoral comentada, p. 198.

${ }^{311}$ Cf. Renato Ventura Ribeiro, Lei eleitoral comentada, p. 496.
} 
O fato é que há relações de trabalho formalizadas em campanhas eleitorais que caracterizam relações de emprego, eis que cumpridos os requisitos ditados pelo art. $3^{\circ}$ da Consolidação das Leis do Trabalho, quais sejam: não eventualidade, subordinação e pagamento de salário. Há trabalhadores como secretarias e telefonistas que são contratados desde o início do período eleitoral, em julho, e permanecem na campanha até seu fim, no início ou final de outubro, dependendo do caso, e são remunerados, são subordinados e seu trabalho não tem caráter eventual neste período. Assim, pode-se alegar eventual inconstitucionalidade do art. 100 da LE, por afronta aos direitos dos trabalhadores previstos no art. $7^{\circ}$ da Constituição.

Ademais, podem as relações de trabalho existentes nas campanhas eleitorais serem consideradas prestações de serviço, havendo inclusive Instrução Normativa da Receita Federal ${ }^{312}$ disciplinando o recolhimento das contribuições previdenciárias de pessoas físicas prestadoras de serviços para os Comitês Financeiros.

São também gastos eleitorais aqueles referentes à realização de pesquisas ou testes pré-eleitorais (inciso XII), itens fundamentais para melhor análise dos rumos da campanha, conforme visto no item 2.1.3 e o pagamento de multas eleitorais (inciso XVI). Tanto Renato Ventura Ribeiro como Joel Cândido consideram a previsão das multas como gastos eleitorais como positivas, já que tem o condão de fazer os candidatos evitarem o cometimento de irregularidades passíveis de condenações pecuniárias, já que o pagamento destas diminui o valor a ser gasto na campanha, já que se deve respeitar o limite registrado pelo partido no momento do registro da candidatura, conforme prevê o art. 18 da $\mathrm{LE}^{313}$.

O outro tipo de gasto eleitoral previsto na LE é a despesa feita por um eleitor em apoio ao seu candidato favorito (art. $27^{314}$ ). Neste caso, não há doação de dinheiro ou de estimável por pessoa física (art. 23 da LE), mas sim um gasto feito por eleitor de forma direta, a beneficiar uma candidatura.

\footnotetext{
${ }^{312}$ Instrução Normativa RFB n. 872, de 26.8.2008.

${ }^{313}$ Cf. Renato Ventura Ribeiro, Lei eleitoral comentada, p. 200-201 e Joel J. Cândido, Direito eleitoral brasileiro, p. 457.

314 "Art. 27. Qualquer eleitor poderá realizar gastos, em apoio a candidato de sua preferência, até a quantia equivalente a um mil UFIR, não sujeitos a contabilização, desde que não reembolsados”.
} 
A crítica a este artigo reside ao fato de que se o gasto do eleitor for equivalente ao máximo de mil UFIR (Unidade Fiscal de Referência) ${ }^{315}$ não precisa ser contabilizado.

Posicionam-se Renato Ventura Ribeiro, Joel Cândido, Olivar Coneglian, Vera Michels ${ }^{316}$ e Adriano Soares da Costa como abertura legal para o cometimento de abuso do poder econômico, pois o dispositivo vai contra a transparência das prestações de contas de campanha. O último autor considera o dispositivo como "um meio de burla da legislação ${ }^{317}$ ". Renato Ventura Ribeiro dá exemplo de que como tal mecanismo pode funcionar, iludindo assim os adversários e a Justiça Eleitoral:

Candidatos com maior disponibilidade de recursos e que eventualmente desejem efetuar mais gastos do que o permitido por lei podem distribuir tais despesas entre diversos eleitores (principalmente entre seus correligionários), com a agravante de não haver fiscalização e tais recursos não serem contabilizados nem como doações nem como gastos, para fins de prestação de $\operatorname{contas}^{318}$.

Critica-se também o fato de que o texto do artigo prevê somente que o eleitor possa fazer tal gasto, e não o cidadão. Um analfabeto, por exemplo, mesmo que não alistado (e, portanto, não eleitor) pode querer beneficiar uma campanha de sua preferência $^{319}$. Ademais, a LE prevê a punição ao candidato que cometer irregularidades nesse assunto (art. 25), mas não há qualquer previsão de punição ao eleitor que desrespeitar o artigo.

\subsubsection{Prestações de contas eleitorais}

As prestações de contas das campanhas eleitorais ganharam capítulo específico na Lei das Eleições, localizado logo após o tópico que disciplina a arrecadação e a aplicação dos recursos financeiros nas campanhas eleitorais.

\footnotetext{
315 A UFIR foi extinta em 2001. Para efeitos nas eleições municipais de 2008, a Resolução TSE n. 22.715/08, em seu artigo 24, caput, fixou o valor em $\mathrm{R} \$ 1.064,10$.

${ }^{316}$ Cf. Renato Ventura Ribeiro, Lei eleitoral comentada, p. 201; Joel J. Cândido, Direito eleitoral brasileiro, p. 459; Olivar Coneglian, Lei das eleições comentada, p. 169 e Vera Michels, Direito eleitoral, p. 188.

${ }^{317}$ Adriano Soares da Costa, Instituições de direito eleitoral, p. 753.

${ }^{318}$ Renato Ventura Ribeiro, Lei eleitoral comentada, p. 202.

${ }^{319}$ Cf. Renato Ventura Ribeiro, Lei eleitoral comentada, p. 204.
} 
A responsabilidade pela feitura da prestação de contas difere, dependendo do tipo da eleição a ser observada. No caso das eleições majoritárias, cabe ao respectivo comitê financeiro (se na circunscrição o comitê foi único, ele é o responsável) a elaboração da prestação de contas, na forma disciplinada pela Justiça Eleitoral por meios de suas resoluções (art. 28 , inciso I e $\S 1^{\circ}$ da LE).

Caso se trate de eleição proporcional, tanto o comitê financeiro como o próprio candidato podem apresentar à Justiça Eleitoral a prestação de contas, de acordo com os modelos de prestação de contas constantes no Anexo da LE (art. 28, inciso II e $\S 2^{\circ}$ da LE).

Nas prestações de contas referentes às eleições majoritárias, o comitê financeiro deve apresentá-la à Justiça Eleitoral, acompanhado dos extratos bancários da conta específica da campanha e também com uma relação dos cheques recebidos, com respectivos números, valores e emitentes (art. $28, \S 1^{\circ}$, in fine).

O art. 30 da Resolução TSE n. 22.715/08 prevê diversos documentos diferentes a serem remetidos pelo Comitê ou candidato à Justiça Eleitoral como parte de suas respectivas prestações de contas. Abaixo, há a relação resumida dos documentos obrigatórios das prestações de contas, com as respectivas descrições e objetivos ${ }^{320}$ :

a) Ficha de Qualificação do Candidato ou do Comitê Financeiro: trata-se de formulário que contém os dados pessoais do candidato, seu limite de gastos, os dados da conta bancária de sua campanha e os dados pessoais do administrador financeiro, caso tenha designado um (art. 30, inciso I da Resolução);

b) Demonstrativo dos Recibos Eleitorais Recebidos: para o controle de tudo o que a campanha recebeu (recursos financeiros ou não, como comercialização de serviços e realização de eventos, ou recursos estimáveis em dinheiro), com os respectivos canhotos de recibo utilizados (art. 30, incisos II e XIII da Resolução);

c) Demonstrativo dos Recibos Eleitorais Distribuídos: documento de responsabilidade dos Comitês Financeiro que tem o escopo de esclarecer os dados relativos aos talonários de recibos eleitorais distribuídos entre os candidatos do partido,

\footnotetext{
${ }^{320}$ Cf. Sídia Maria Porto Lima, Prestação de contas e financiamento de campanhas eleitorais. 2. ed., rev. e atual., Curitiba: Juruá, 2009, p. 129-145.
} 
devendo ser incluídas informações sobre a data em que ocorreu a distribuição, a numeração dos recibos distribuídos e a quantidade de talonários / recibos entregues (art. 30, inciso III);

d) Demonstrativo dos Recursos Arrecadados: neste formulário, devem estar declarados todos os recursos arrecadados pela campanha. No caso de recursos estimáveis em dinheiro, deve haver "notas explicativas com descrição, quantidade, valor unitário e avaliação pelos preços praticados no mercado, com indicação da origem da avaliação e do respectivo recibo eleitoral" (art. 30, inciso IV e $\S 1^{\circ}$ da Resolução TSE n. 22.715/08);

e) Demonstrativo das Despesas Pagas após a Eleição: aqui, devem ser declarados os gastos eleitorais feitos após a data da eleição (permissão prevista no art. $21, \S 1^{\circ}$ da Resolução). As obrigações assumidas até a data da eleição, mas não pagas até o dia do pleito devem contar desse demonstrativo (art. 30, inciso $\mathrm{V}$ e $\S 2^{\mathbf{o}}$ da Resolução);

f) Demonstrativo de Receitas e Despesas: relatório que especificará todas as receitas, despesas, saldos e eventuais sobras de campanha (art. 30, incisos VI, X e $\S 3^{\circ}$ da Resolução)

g) Demonstrativo do Resultado da Comercialização de Bens e da Realização de Eventos: neste demonstrativo, devem constar (i) o período de comercialização ou de realização do evento; (ii) o valor total arrecadado; (iii) o valor da aquisição dos bens e insumos para a comercialização ou realização de eventos, mesmo que tenham sido doados; (iv) a identificação completa de todos os doadores (art. 30, inciso VII e $\S 4^{\circ}$ da Resolução);

h) Conciliação Bancária: relatório contendo os débitos e os créditos eventualmente ainda não lançados pelo banco. Este relatório deve ser apresentado somente para justificar a diferença (se houver) entre o saldo financeiro do Demonstrativo de Receitas de Despesas e o saldo bancário constante no extrato bancário (art. 30, inciso VIII e $\S 5^{\circ}$ da Resolução);

i) Termo de Entrega à Justiça Eleitoral dos recibos eleitorais não utilizados: este termo integrante dos autos da prestação de contas estará acompanhado dos respectivos recibos não utilizados, cabendo à Justiça Eleitoral sua guarda até o trânsito em julgado da decisão sobre prestação de contas, devendo após isso ser inutilizados (art. 30, inciso IX e $\S 7^{\circ}$ da Resolução); 
j) Demonstrativo de Doações Efetuadas a Candidatos ou a Comitês Financeiros: relatório que esclareça todas as doações efetuadas pelo candidato ou comitês a outros candidatos ou outros comitês (estas doações são consideradas na contabilidade do doador como gastos eleitorais), previsto no art. 30, inciso XI da Resolução;

k) Extratos da conta bancária aberta em nome do candidato ou do comitê financeiro: servem os extratos para demonstrar toda a movimentação financeira (ou a ausência) ocorrida no período de campanha. Os extratos devem ser definitivos, sendo proibida a apresentação de: (i) extrato parcial; (ii) extrato que haja omissão de qualquer movimentação ocorrida; (iii) extrato sem validade legal; e (iv) extrato sujeitos à alteração (art. 30, inciso XII e $\S 6^{\circ}$ da Resolução) ${ }^{321}$;

1) Documentação referente à sobra de campanha: havendo saldo monetário positivo na conta bancária eleitoral, deve o comitê ou candidato apresentar guia de depósito comprovando o recolhimento à respectiva direção partidária das sobras financeiras de campanha, acompanhada da declaração da direção partidária comprovando o recebimento das sobras de campanha constituídas por bens e/ou materiais permanentes (art. 30, incisos XIV e XV da Resolução),

m) Documentação dos recursos do Fundo Partidário: documentos que comprovem a regularidade dos gastos eleitorais realizados com recursos do Fundo Partidário (art. 30, inciso XVI da Resolução).

Todos os documentos das prestações de contas deverão ser assinados, obrigatoriamente, pelo candidato e seu administrador financeiro de campanha (em caso de prestação de contas de candidato) e pelo presidente e tesoureiro do comitê financeiro (em caso de prestação de contas de comitê), conforme determinação do $\S 8^{\circ}$ do art. 30 da Resolução TSE n. 22.715/08.

$\mathrm{O} \S 3^{\circ}$ do art. 28 prevê que todos os dados financeiros apresentados na prestação de contas deverão ser convertidos em UFIR (Unidade Fiscal de Referência). Este parágrafo tornou-se letra morta, em virtude do fato de a UFIR ter sido extinta em 2001.

\footnotetext{
${ }^{321} \mathrm{O}$ encaminhamento dos extratos bancários à Justiça Eleitoral é disciplinado pela Carta Circular-Bacen n. 3.341, de 30.9.2008 e pela Resolução TSE n. 22.867/08.
} 
A Lei n. 11.300/06 incluiu no art. 28 o $§ 4^{\circ}$, que prevê as prestações de contas de campanha parciais. Na legislação vigente anteriormente, os comitês e candidatos somente tinham que apresentar suas respectivas prestações de contas quando findo o período eleitoral. Agora, com o advento do texto em comento, devem os mesmos apresentar prestações de contas em 6 de agosto e 6 de setembro, com relatório que discriminará as receitas recebidas (em dinheiro ou em estimável em dinheiro) para as campanhas, além dos gastos realizados.

Estes relatórios, chamados pela doutrina de prestações de contas parciais, devem ser divulgados pelos comitês e pelos candidatos pela Internet, em sítio criado pela Justiça Eleitoral para esse fim ${ }^{322}$.

$\mathrm{O} \S 4^{\circ}$ do art. 28 tem como principal vantagem o fato de obrigar candidatos e comitês a guardarem coerência entre as receitas e gastos declarados na prestação parcial e a prestação de contas final ${ }^{323}$.

Há, porém, duas críticas a serem feitas a este parágrafo. A primeira é o fato de prever a obrigatoriedade de coligações apresentarem as prestações de contas parciais. Conforme já estudado anteriormente, não há nenhum outro dispositivo legal que preveja a prestação de contas por coligação (já que também não recebem recursos e não realizam gastos), sendo tal obrigação dos partidos, candidatos ou comitês.

O segundo comentário crítico a ser feito é o fato de os candidatos, partidos ou comitês não precisarem apresentar em suas prestações de contas parciais a indicação dos nomes dos doadores e os respectivos valores doados, que somente serão divulgados na prestação de contas final/definitiva, conforme texto do $\S 4^{\circ}$ do art. 28 , in fine.

Esta permissão vai de encontro ao da legislação, que pretende dar maior transparência ao financiamento das campanhas eleitorais. Ao mesmo tempo, reconhecese que se fosse obrigatória a identificação dos doadores e dos valores doados, muitos

\footnotetext{
322 Todo o procedimento a ser feito pelo comitê ou pelo candidato para a publicação das prestações de contas parciais na Internet foi disciplinado, nas eleições de 2008, pela Resolução TSE n. 22.868/08.

${ }^{323}$ Cf. Joel J. Cândido, Direito eleitoral brasileiro, p. 461.
} 
somente efetuariam a doação após a data de 6 de setembro, com o objetivo de não serem vinculados aos candidatos/partidos de sua preferência antes da data da eleição ${ }^{324}$.

O art. 29 da LE prevê as obrigações dos comitês financeiros no processo de prestação de contas, ou seja, desde o recebimento das contas prestadas pelos candidatos (majoritários, obrigatoriamente; e proporcionais, se o candidato optar por prestar suas contas por meio do comitê partidário) até o encaminhamento da prestação à Justiça Eleitoral.

Sua primeira obrigação é a de fazer uma conferência entre os valores transferidos pelo próprio comitê aos seu candidato majoritário (valores estes constantes em seus registros financeiros e contábeis) e os valores declarados pelo candidato como recebidos do comitê (art. 29, inciso I).

Depois, deve o comitê resumir as informações contidas nas prestações de contas recebidas dos candidatos para apresentar à Justiça Eleitoral um demonstrativo consolidado das campanhas de seus candidatos (art. 29, inciso II). Segundo Olivar Coneglian, para cada candidato, o comitê deve preparar o demonstrativo que contenha ao menos as seguintes informações: (i) quanto o comitê repassou ao candidato de verbas do Fundo Partidário; (ii) quanto o comitê repassou ao candidato de recursos advindos de outras fontes; (iii) quanto o candidato arrecadou, de forma independente; (iv) quanto foi gasto; (v) com o quê foi gasto; (vi) destinos dos gastos; e (vii) data e local dos gastos ${ }^{325}$.

Todas as prestações de contas devem ser entregues à Justiça Eleitoral no prazo máximo de 30 dias após a realização das eleições. No caso de segundo turno, as prestações de contas dos candidatos participantes da nova rodada eleitoral devem ser encaminhadas em no máximo 30 dias após a realização da segunda eleição (art. 29, incisos III e IV).

No caso de candidatos às eleições proporcionais que optaram por fazer prestações de contas próprias, individuais, o prazo para a apresentação de sua prestação à Justiça Eleitoral é de 30 dias após a data da eleição (art. 29, § $1^{\circ}$ ).

\footnotetext{
${ }^{324}$ Cf. Renato Ventura Ribeiro, Lei eleitoral comentada, p. 209.

${ }^{325}$ Cf. Olivar Coneglian, Lei das eleições comentada, p. 176.
} 
Os prazos acima citados não são preclusivos. Portanto, há a possibilidade de os comitês e/ou os candidatos entregarem as prestações de contas fora do prazo fixado legalmente. Porém, os candidatos não serão diplomados enquanto o atraso persistir (art. $\left.29, \S 2^{\circ}\right)$.

A Lei n. 12.034/09 incluiu o $\S 3^{\circ}$ no art. 29 , que trata das dívidas de campanha (ou seja, saldo negativo entre os valores recebidos e os valores aplicados nos gastos eleitorais). No caso de haver saldo negativo na prestação de contas apresentada pela Justiça Eleitoral, o débito pode ser assumido pelo partido político, em decisão interna do órgão nacional de direção.

Assim sendo, o candidato ou comitê tem até o prazo final da apresentação da prestação de contas à Justiça Eleitoral para pagar eventuais débitos. Após esse prazo, o partido poderá assumir a dívida, já que se a dívida não for paga, poderá acarretar a desaprovação das prestações de contas apresentadas. Tanto é que se o partido decidir assumir a dívida, a responsabilidade por ela passa a ser do órgão partidário da respectiva circunscrição eleitoral e do candidato, responsabilidade essa solidária. Nessa hipótese, a existência do débito não será causa motivadora da rejeição das contas de campanha (art. 29, § 4º, incluído pela Lei n. 12.034/09).

Este dispositivo pode ensejar a má administração das campanhas eleitorais por parte principalmente dos candidatos, já que se fizerem gastos maiores que o valor recebido, provavelmente os partidos assumirão a responsabilidade por suas dívidas de campanha, já que não interessa nem ao candidato e nem ao partido (principalmente se o candidato tiver sido eleito) que suas contas sejam rejeitadas.

A legislação também disciplina o saldo positivo de campanha, ou seja, quando a receita de campanha for maior que os gastos realizados. $\mathrm{O}$ saldo positivo é intitulado legalmente como "sobra de campanha", conforme disposição do art. 31, caput, da LE ${ }^{326}$.

\footnotetext{
${ }^{326}$ Também são sobras de campanha, conforme definição legal contida na Resolução TSE n. 22.715/08 (art. 29, incisos II e III), "os recursos de origem não identificada" e "os bens e materiais permanentes". Recursos de origem não identificada, segundo a mesma Resolução (art. 25, $\S 1^{\text {o }}$ ), são os recursos sem identificação do doador e/ou com identificação inválida do doador no CPF ou no CNPJ. Estes recursos
} 
Prevê o art. 31, caput, com redação alterada pela Lei n. 12.034/09, que havendo sobra de campanha, deve-se esperar o trânsito em julgado da decisão que julgou respectiva prestação de contas para que esses recursos sejam transferidos ao órgão partidário na circunscrição do pleito (ou seja, sobra de campanha em eleição municipal vai para o diretório municipal, por exemplo) ou para a coligação. Se a sobra for destinada para a coligação, deve haver uma divisão igualitária entre os partidos que a compõem. No entanto, não deveria haver a possibilidade legal de distribuição das sobras entre os partidos coligados, eis que elas não arrecadam, não aplicam os recursos e não fazem prestação de contas. Ademais, os comitês financeiros são sempre partidários, e não das coligações ${ }^{327}$.

O parágrafo único do art. 31 também teve sua redação alterada pela Lei n. 12.034/09. Determina o novo texto que os recursos amealhados pelos partidos a título de sobra de campanha devem ser declarados nas respectivas prestações de contas, sendo necessária a respectiva identificação do candidato responsável pelo saldo positivo de campanha.

A novidade, porém, é que o novo texto não prevê destinação obrigatória para esses recursos. Anteriormente, as sobras de campanha deveriam ser destinadas pelos partidos obrigatoriamente para o fomento de suas fundações/institutos partidários de pesquisa e de doutrinação e educação política (criadas pela LPP, art. 44, inciso IV).

Ao julgar as contas, a Justiça Eleitoral poderá decidir de quatro formas, conforme incisos acrescidos ao art. 30 da LE pela Lei n. 12.034/09:

a) pela aprovação, quando tudo estiver regular;

b) pela aprovação com ressalvas, quando houver falhas nas prestações de contas que não sejam graves o suficiente para comprometer a regularidade das contas;

c) pela desaprovação, quando as contas apresentarem falhas graves, que possam comprometer sua regularidade;

d) pela ausência de prestação, quando as contas não tiverem sido apresentadas.

não podem ser aplicados nas campanhas, restando caracterizados como sobras de campanha (art. 25, caput e $\$ 2^{\circ}$ ).

${ }^{327}$ Cf. Olivar Coneglian, Lei das eleições comentada, p. 187. 
No último caso, constatada a não prestação de contas, deve a Justiça Eleitoral emitir notificação para que o candidato ou o comitê apresente a prestação, em 72 horas, devendo a notificação constar expressamente a obrigação de o candidato ou comitê realizar a prestação de contas eleitorais. Se mesmo assim não forem prestadas, o candidato fica impedido de receber a certidão de quitação eleitoral durante o curso do mandato ao qual concorreu e, ultrapassado este prazo, até a apresentação das contas (art. 42, inciso I da Resolução TSE n. 22.715/08) ${ }^{328}$. Ao comitê financeiro inadimplente cabe a sanção de perda do direito do recebimento do Fundo Partidário no ano seguinte ao da decisão, sanção essa para o órgão partidário ao qual o comitê é vinculado (art. 42, inciso II da Resolução).

Não há, porém, previsão legal para a simples rejeição de contas, conforme a possibilidade dada pelo art. 30, inciso III, devendo o Ministério Público ou o interessado ingressar com ação de apuração de abuso do poder econômico (AIME, AIJE, recurso contra a diplomação) ${ }^{329}$.

Quanto à certidão de quitação eleitoral citada anteriormente, a Resolução TSE n. 22.715/08 repete interpretação fixada pelo TSE desde a eleição de 2004 (por meio da Resolução n. 21.823/04) a respeito da expedição ou não da certidão de quitação eleitoral em caso de rejeição ou não apresentação de prestação de contas.

$\mathrm{O}$ art. $27, \S 5^{\circ}$ combinado com o art. 42, inciso I (no caso de não apresentação de contas) e o art. $41, \S 3^{\circ}$ (no caso de rejeição das contas prestadas), todos da aludida Resolução, definem que o candidato não terá direito à certidão de quitação eleitoral enquanto durar o mandato pelo qual concorreu, sendo que tal prazo se estende $a d$ infinitum em caso de o candidato que não apresentou suas contas continuar inadimplente perante a Justiça Eleitoral.

\footnotetext{
${ }^{328}$ Ademais, a Justiça Eleitoral fará lista com os nomes dos candidatos inadimplentes e a encaminhará ao Ministério Público, para as medidas que entender cabíveis (art. 44, caput, da Resolução TSE n. 22.715/08).

${ }^{329}$ Cf. Olivar Coneglian, Lei das eleições comentadas, p. 180 e Renato Ventura Ribeiro, Lei eleitoral comentada, p. 217.
} 
A certidão de quitação eleitoral consiste em documento necessário ao registro da candidatura, conforme previsão do art. $11, \S 1^{\circ}$, inciso VI da LE. O conceito de quitação eleitoral, segundo a Resolução TSE n. 22.823, de 15.6.2004,

(...) reúne a plenitude do gozo dos direitos políticos, o regular exercício do voto, salvo quando facultativo, o atendimento a convocações da Justiça Eleitoral para auxiliar os trabalhos relativos ao pleito, a inexistência de multas aplicadas, em caráter definitivo, pela Justiça Eleitoral e não remitidas, excetuadas as anistias legais, e a regular prestação de contas de campanha eleitoral, quando se tratar de candidatos $^{330}$. (grifo nosso).

Assim sendo, desde a edição da Resolução acima citada, os candidatos que não prestassem contas ou que tivessem suas contas rejeitadas não teriam direito à certidão de quitação eleitoral, documento obrigatório para o registro de futuras candidaturas.

Levando-se em conta os dispositivos da Resolução TSE n. 22.715/08, que disciplinou as últimas eleições municipais, o candidato que não apresentou contas não terá a certidão eleitoral por quatro anos, ou seja: não poderá ser candidato nem nas eleições de 2010 e nem no pleito de 2012. E mais: enquanto não prestar as contas ainda não apresentadas, não poderia ser candidato também nas eleições posteriores (2014 em adiante). Já o candidato que teve suas contas reprovadas não poderia ser candidato nas eleições de 2010 e 2014.

Essa nova interpretação do TSE, que teve como principal conseqüência a maior preocupação dos candidatos com a apresentação de suas prestações de contas eleitorais, já que a desaprovação de contas passou de ato meramente formal da Justiça Eleitoral para ser ato dotado de real eficácia para sancionar os candidatos que cometem irregularidades nas prestações de $\operatorname{contas}^{331}$.

Alega-se que esta nova interpretação do TSE cria nova sanção no ordenamento jurídico eleitoral brasileiro por meio de Resolução e não por meio de lei, ferindo assim o princípio constitucional da legalidade. O fato é que na verdade o TSE atribuiu nova

\footnotetext{
${ }^{330}$ Resolução TSE n. 22.823, de 15.6.2004. (Processo Administrativo n. 19.205, Rel. Min. Francisco Peçanha Martins).

${ }^{331}$ Cf. Adriano Denardi Júnior, "Prestação de contas de campanha, quitação eleitoral e inelegibilidade", in Revista de Doutrina e Jurisprudência TRE-MG, n. 18, 2008, p. 10.
} 
eficácia a um inciso da LE (inciso VI do $\S 1^{\circ}$ do art. 11 , que prevê a certidão de quitação eleitoral como documento indispensável para o registro de candidatura).

A obtenção desta certidão alude, por parte do candidato, o cumprimento de todas as suas obrigações político-eleitorais, entre elas - no caso de o candidato ter sido postulante também na eleição anterior - da entrega da prestação de contas e de sua não reprovação. Sendo inadimplente perante a Justiça Eleitoral, simplesmente não poderia ser candidato ${ }^{332}$.

A Lei n. 12.034/09, porém, incluiu ao art. 11 da LE o $§ 7^{0^{333}}$. Este texto deixou bastante claro que a certidão de quitação eleitoral, no que toca à prestação de contas, só não será emitida se as contas de campanha eleitoral não forem apresentadas, extinguindo a possibilidade de não de expedir a certidão também no caso de rejeição de contas, boa novidade trazida ao ordenamento por meio da nova interpretação do TSE.

Para facilitar o posterior julgamento das prestações de contas pela Justiça Eleitoral, a Resolução TSE n. 22.715/08 prevê mecanismos de circularização prévia, ou seja, confronto de dados para melhor controle das receitas e aplicações constantes nas prestações de contas.

O primeiro deles é a declaração de doadores e fornecedores diretamente à Justiça Eleitoral sobre as doações e despesas realizadas pelos candidatos e/ou comitês. Nesta declaração, deve haver a identificação do declarante (com CPF ou CNPJ), devendo a Justiça incluir em sistema informatizado específico tal informação para a divulgação nas páginas da Internet dos Tribunais Regionais Eleitorais (art. 48, § $2^{\circ}$ ).

A Justiça Eleitoral também tem a competência de "circularizar fornecedores e doadores", com o objetivo de obter informações prévias para o exame posterior das contas (art. 48, $\S 3^{\circ}$ ), devendo as informações obtidas por meio dos dois mecanismos

\footnotetext{
${ }^{332}$ Cf. Denise Goulart Schlickmann, Financiamento de campanhas eleitorais, p. 332.

333 “Art. 11. (...)

$\S 7^{\circ}$ A certidão de quitação eleitoral abrangerá exclusivamente a plenitude do gozo dos direitos políticos, o regular exercício do voto, o atendimento a convocações da Justiça Eleitoral para auxiliar os trabalhos relativos ao pleito, a inexistência de multas aplicadas, em caráter definitivo, pela Justiça Eleitoral e não remitidas, e a apresentação de contas de campanha eleitoral
} 
normativos acima descritos servir de subsídio para o julgamento das prestações de contas.

A Lei n. 11.300/06 alterou a redação do $\S 1^{\circ}$ do art. 30 , determinando que somente as contas dos candidatos eleitos devam ser julgadas antes da diplomação, devendo a decisão ser publicada em até oito dias antes da diplomação. Esta nova disposição tem como objetivo acelerar o julgamento das prestações de contas (a redação anterior previa que todas as prestações deveriam ser julgadas antes da diplomação), dando prioridade às contas dos candidatos eleitos.

Determina a lei que as prestações de contas que constem erros formais e/ou materiais corrigidos não ensejem a rejeição (desaprovação) das contas, nem a cominação de sanções ao candidato ou ao partido. Erros formais e materiais são, segundo Carlos Velloso e Walber Agra, os erros presentes nas prestações de contas que: (...) não observaram os padrões atinentes à aritmética ou que apresentem equívocos crassos, que são reconhecidos de forma tautológica. Como não provocam prejuízos a qualquer das partes envolvidas ou à lisura da eleição, bem como se perfilham no sentido de tornar exequível um procedimento célere e eficiente, o magistrado, sponte propria, pode mandar suprir esses pecadilhos ${ }^{334}$.

A Lei n. 12.034/09 acrescentou o $\S 2^{\circ}$-A ao art. 30, determinando que a existência de erros materiais ou formais irrelevantes no conjunto da prestação de contas, mesmo que não corrigidos e que não comprometam o seu resultado, não acarreta a rejeição das contas.

A hipótese acrescida é infeliz, pois nem ao menos prevê a necessidade de o partido ou candidato corrigir tal erro. Ademais, conforme entendimento de Carlos Velloso e Walber Agra, estes erros naturalmente não provocam prejuízos à lisura eleitoral; assim sendo, não havia real necessidade da inclusão deste parágrafo.

Para o melhor exame das contas eleitorais, a Justiça Eleitoral pode requisitar técnicos dos Tribunais de Contas da União, dos Estados, do Distrito Federal ou dos Municípios por quanto tempo foi necessário (art. $30, \S 3^{\circ}$ ). Isso se deve ao fato de a

${ }^{334}$ Carlos Mário da Silva Velloso e Walber de Moura Agra, Elementos de direito eleitoral, p. 232. 
infra-estrutura da Justiça Eleitoral não ser grande o suficiente para que possa dar contas de todas as prestações de contas apresentadas em cada eleição ${ }^{335}$.

Se a Justiça Eleitoral detectar qualquer indício de irregularidade nas contas analisadas, pode requisitar do comitê ou do candidato informações adicionais para o melhor esclarecimento do indício e também determinar diligências com o intuito de amealhar novas informações, dados ou sanear as falhas apresentadas (art. 30, $\S 4^{\circ}$ ).

Outra novidade muito importante trazida pela Lei n. 12.034/09 é a previsão de um rito processual para a prestação de contas, com determinação de prazos e possíveis recursos a serem apresentados.

Assim sendo, prevê o $\S 5^{\circ}$ do art. 30 que o prazo recursal contra a decisão da Justiça Eleitoral que julgar as contas é de três dias, prazo este contado a partir da publicação da decisão no Diário Oficial.

Em caso de decisão exarada por um Tribunal Regional Eleitoral, cabe recurso especial eleitoral ao TSE, no mesmo prazo de três dias contados a partir da publicação da decisão no Diário Oficial (art. 30, $\S 6^{\circ}$ da LE), caso esta decisão tenha sido proferida contra disposição expressa da Constituição ou de lei vigente (art. $121, \S 4^{\text {o }}$, inciso I da Constituição) ou se a decisão recorrida contenha divergência jurisprudencial entre dois ou mais tribunais eleitorais (art. 121, $\S 4^{\circ}$, inciso II da Constituição). O $\S 7^{\circ}$ do art. 30 da LE também previu que as mudanças realizadas no art. 30 da LE pelo advento da Lei $n$. 12.034/09 já se aplicam aos processos de prestações de contas ainda pendentes de julgamento na Justiça Eleitoral.

A documentação referente às contas eleitorais deve ser guardada pelos partidos ou pelos candidatos pelo prazo máximo de 180 dias após a diplomação. Porém, se não houve o trânsito em julgado de qualquer processo relativo às contas (AIME, AIJE, recurso contra a diplomação ou o próprio julgamento da prestação de contas, por

\footnotetext{
${ }^{335}$ Renato Ventura Ribeiro entende que havendo resposta negativa ao pedido da Justiça Eleitoral sem justa causa, há a caracterização do crime de desobediência, conforme art. 347 do CE (Renato Ventura Ribeiro, Lei eleitoral comentada, p. 216).
} 
exemplo ${ }^{336}$ ) a decisão sobre a prestação de contas, a documentação deve ser mantida até a decisão final ser proferida (art. 32, caput, e parágrafo único da LE). Percebe-se, como em outros dispositivos da Lei das Eleições, que não há previsão de sanção para o partido ou candidato que descumprir a regra do art. 32 da LE ${ }^{337}$.

Há também no capítulo da "Prestação de Contas" da Lei das Eleições dispositivo incluído pela Lei n. 11.300/06, porém com redação alterada pela Lei n. 12.034/09, que dá a possibilidade de partido ou coligação apresentar AIJE no sentido de apurar eventual conduta que tenha tido o condão de infringir normas relativas à arrecadação e gastos de campanha eleitoral. Trata-se do art. 30-A da $\mathrm{LE}^{338}$.

O caput do artigo em comenta menciona a possibilidade do partido ou coligação "representar" à Justiça Eleitoral, termo este que pode ensejar interpretações de que o rito a ser seguido é o da representação eleitoral, de caráter sumário, previsto no art. 96 da LE.

No entanto, entende-se que a ação cabível para a hipótese prevista no art. 30-A é o da AIJE, eis que no próprio caput há menção à "abertura de investigação judicial", além de o $\S 1^{\circ}$ do artigo explicitar que o rito a ser seguido é o do art. 22 da LI. Esta AIJE pode ser proposta com base apenas em indícios, mas deve conter em sua petição inicial indicação de quais os meios probatórios serão utilizados no transcorrer da ação para a devida comprovação da irregularidade ${ }^{339}$.

Este novo artigo é a base fundamental do espírito das mudanças sofridas na Lei das Eleições trazidas pela Lei n. 11.300/06, que é a de fazer as campanhas eleitorais transcorrerem de maneira mais limpa, mais transparente e com maior equilíbrio entre os

\footnotetext{
${ }^{336}$ Cf. Renato Ventura Ribeiro, Lei eleitoral comentada, p. 222.

${ }^{337}$ Cf. Adriano Soares da Costa, Instituições de direito eleitoral, p. 762.

338 “Art. 30-A. Qualquer partido político ou coligação poderá representar à Justiça Eleitoral, no prazo de 15 (quinze) dias da diplomação, relatando fatos e indicando provas, e pedir a abertura de investigação judicial para apurar condutas em desacordo com as normas desta Lei, relativas à arrecadação e gastos de recursos.

$\S 1^{0} \mathrm{Na}$ apuração de que trata este artigo, aplicar-se-á o procedimento previsto no art. 22 da Lei Complementar $\mathrm{n}^{0}$ 64, de 18 de maio de 1990, no que couber.

$\S 2^{\underline{0}}$ Comprovados captação ou gastos ilícitos de recursos, para fins eleitorais, será negado diploma ao candidato, ou cassado, se já houver sido outorgado.

$\S 3^{\circ} \mathrm{O}$ prazo de recurso contra decisões proferidas em representações propostas com base neste artigo será de 3 (três) dias, a contar da data da publicação do julgamento no Diário Oficial".

${ }^{339}$ Cf. Renato Ventura Ribeiro, Lei eleitoral comentada, p. 218.
} 
postulantes. Ressalte-se que a Lei n. 11.300/06 teve como motivo para seu nascimento os debates congressuais de reforma do cenário político brasileiro após o surgimento do escândalo do "mensalão"340.

Apesar de seu espírito nobre, a inclusão desse artigo na LE também sofreu críticas, pois já haveria no ordenamento jurídico vigente norma com o mesmo diapasão, que é o art. 22 da LI. Assim sendo, "em matéria de combate às ilegalidades (...) pertinentes à arrecadação, gasto e prestação de contas no particular, nenhuma vantagem ou melhora específica nos trouxe esta 'Minirreforma política' de que já não dispuséssemos em nosso ordenamento ${ }^{341 "}$ ".

A captação de recursos ou o gasto eleitoral fora da lei é, conforme ditame do $\S$ $2^{\circ}$ do art. 30-A, nova hipótese de infração prevista na LE, ensejando a não expedição do diploma ao candidato infrator ou sua cassação, se já outorgado. Não há qualquer previsão, porém, quanto à eventual cassação de registro de candidatura, fato este criticado por Renato Ventura Ribeiro ${ }^{342}$. Apesar de o rito ser o do art. 22 da LI, não há possibilidade jurídica de o infrator condenado também se tornar inelegível ${ }^{343}$, já que somente Lei Complementar pode criar hipóteses de inelegibilidade.

O prazo recursal contras as decisões proferidas em sede de AIJE com base no art. 30-A da LE é de três dias, contados da data da publicação da decisão no Diário oficial (art. 30-A, § $3^{\circ}$, incluído pela Lei n. 12.034/09) ${ }^{344}$.

A responsabilidade sobre a eventual conduta de captação ou aplicação ilícita de recursos nas campanhas eleitorais é do candidato, que é o responsável pela administração da campanha e pela prestação de contas. $\mathrm{O}$ administrador financeiro de campanha, conforme disposição dos arts. 20 e 21 da LE, também pode ser responsabilizado, mas o art. 30-A não prevê qualquer punição a ele.

\footnotetext{
${ }^{340}$ Cf. José Jairo Gomes, Direito eleitoral, 3. ed., rev. e ampl., Belo Horizonte: Del Rey, 2008, p. 412.

${ }^{341}$ Joel J. Cândido, Direito eleitoral brasileiro, p. 469.

${ }^{342}$ Cf. Renato Ventura Ribeiro, Lei eleitoral comentada, p. 219.

${ }^{343}$ Cf. Olivar Coneglian, Lei das eleições comentada, p. 184 e José Jairo Gomes, Direito eleitoral, p. 414.

344 José Jairo Gomes (Direito eleitoral, p. 414), entende que o recurso ora previsto não tem efeito suspensivo, conforme ditame do art. 257 do CE.
} 
Vagner Bispo da Cunha defende que para a caracterização da ilicitude prevista no art. 30-A, devem estar presentes as seguintes condições: (i) recursos movimentados ilicitamente por candidato e/ou administrador financeiro; (ii) recursos movimentados paralelamente à conta bancária de campanha, o chamado "caixa dois"; (iii) recursos movimentados ilicitamente provindos de fontes vedadas; e (iv) utilização desses recursos ilícitos na campanha eleitoral em gastos eleitorais não previstos na norma ${ }^{345}$.

Porém, a movimentação de recursos paralelamente à conta bancária de campanha pode muito bem advir de recurso obtido junto à entidade que tenha a permissão legal para fazer a doação legalmente. $O$ candidato infrator pode não contabilizar o recurso recebido, se essa for sua vontade, advindo tanto de um banco privado, uma empreiteira ou até mesmo de uma pessoa física como também se o recurso tiver como origem um sindicato ou organização religiosa.

Reconhece-se que se o recurso vier de fonte vedada, o candidato não fará a declaração do recurso em prestação de contas, pois isso acarretaria uma confissão de ilicitude oficial. Mas para uma das duas hipóteses de caracterização do crime, que é a de captação ilícita, pode sim o recurso ter como origem fonte permitida legalmente. Corrobora com essa afirmação José Jairo Gomes, ao afirmar que

(...) o termo captação ilícita remete tanto à fonte quanto à forma de obtenção de recursos. Assim, abrange não só o recebimento de recursos de fontes ilícitas e vedadas (vide artigo 24 da LE), como também sua obtenção de modo ilícito, embora aqui a fonte seja legal. Exemplo desse último caso são os recursos obtidos à margem do sistema legal de controle, que compõem o que se tem denominado "caixa dois" de campanha ${ }^{346}$.

No mesmo sentido deve ser ponderada a exigência para a caracterização da infração no caso de gastos ilícitos. Assim, não deve o gasto ter tido como destino somente hipótese não abrangida pelo rol de gastos eleitorais do art. 26 da LE como a única hipótese de caracterização da infração do art. 30-A (por exemplo, em confecção de brindes para distribuição ao eleitorado)

\footnotetext{
${ }^{345}$ Cf. Wagner Bispo da Cunha, "O artigo 30-A e as suas implicações. Arrecadação, gastos e prestação de contas de campanha eleitoral - Eleições 2008", in Revista IOB de Direito Administrativo, ano III, n. 34, out./2008, p. 11.

${ }^{346}$ José Jairo Gomes, Direito eleitoral, p. 413.
} 
Se o gasto foi feito em propaganda eleitoral ou para o pagamento de remuneração de pessoal de campanha, por exemplo, mas sem o recurso ter passado pela conta bancária de campanha ou sem haver a contabilização desses gastos na prestação de contas de campanha, há também a conduta infracional prevista no art. 30-A da LE.

Há também discussão doutrinária no que se refere à necessidade de a conduta ilícita prevista no art. 30-A ter potencialidade lesiva para que o infrator possa sofrer a sanção prevista.

Wagner Bispo da Cunha defende que diante dos elementos necessários, no seu entender, para a caracterização da conduta (já expostos anteriormente), a infração do art. 30-A tem natureza de abuso do poder econômico, sendo necessário assim medir a potencialidade do ato lesivo para se justificar eventual cassação ou não expedição do diploma do candidato infrator ${ }^{347}$.

No entanto, há também a posição de que a infração prevista no art. 30-A não tem natureza de abuso do poder econômico, afastando a necessidade de exame de potencialidade lesiva do ato. Para Jairo Gomes, o bem protegido pelo artigo em comento é a "higidez ou a regularidade da campanha", fato este que por si só não requer a existência de potencialidade para haver um desequilíbrio do processo eleitoral, mesmo argumento presente na análise do art. 41-A (compra de votos) e art. 73 (condutas vedadas aos agentes públicos), ambos da $\mathrm{LE}^{348}$.

Reconhece Gomes, porém, que apesar de não haver a exigência da existência da potencialidade lesiva do ato previsto no art. 30-A, também não deve ser afastada a incidência dos princípios da proporcionalidade e da razoabilidade. Se a irregularidade

\footnotetext{
${ }^{347}$ Cf. Wagner Bispo da Cunha, "O artigo 30-A e as suas implicações. Arrecadação, gastos e prestação de contas de campanha eleitoral - Eleições 2008”, p. 15.

${ }^{348}$ Cf. José Jairo Gomes, Direito eleitoral, p. 413. No mesmo sentido e com a mesma argumentação, Olivar Augusto Roberti Coneglian, ao afirmar que a infração prevista no art. 30-A não caracteriza abuso do poder econômico, não havendo, portanto, necessidade de se examinar a possibilidade de potencialidade lesiva. (Olivar Augusto Roberti Coneglian, Inelegibilidade: inelegibilidade $e$ proporcionalidade, inelegibilidade e abuso de poder. Curitiba: Juruá, 2008, p. 186).
} 
foi pequena, "sem maior repercussão no contexto da campanha do candidato (...) que não agrida seriamente o bem jurídico tutelado", não deve o candidato ser sancionado ${ }^{349}$.

Porém, como mencionado no início dos comentários referentes a este artigo, a Lei n. 12.034/09 alterou a redação do caput do art. 30-A de forma decisiva, tornando o artigo na prática ineficaz ${ }^{350}$, eis que a nova redação determinou que a AIJE com base no art. 30-A da LE só poderá ser apresentada à Justiça Eleitoral após a diplomação, no prazo de quinze dias (art. 30-A, caput).

$\mathrm{Na}$ redação anterior, havia a possibilidade de se apresentar a AIJE com base em atos em desacordo com as normas relativas à arrecadação e gastos de recursos de campanha desde o início do período eleitoral ${ }^{351}$.

Esta mudança acarretou tal diagnóstico pelo fato de a redação anterior ter como grande vantagem a possibilidade de os legitimados ativos (partidos, coligações e Ministério Público) terem a possibilidade de apresentar a ação a qualquer momento do período eleitoral ou pós-eleitoral, não havendo necessidade de se aguardar pelo julgamento da prestação de contas e/ou da diplomação, fato este que poderia dar maior celeridade ao serviço jurisdicional e mais rapidez para a aplicação da sanção.

Com a redação atual, o candidato infrator já terá o status de diplomado, sendo que a ação será proposta poucos dias antes de sua posse, fato esse que dificulta na prática a cominação da sanção prevista. Há um sentimento em parte da sociedade de que a apresentação de ações judiciais visando à cassação de diplomas ou a impugnação de mandatos na verdade se tornaram verdadeiros "terceiros turnos eleitorais", nos quais os candidatos derrotados pelo voto popular procuram a vitória eleitoral nos Tribunais, com decisões que possam no fundo ignorar a vontade do eleitorado.

Ademais, a nova redação pode também na prática esvaziar seu conteúdo, eis que ao prever que somente após a diplomação a ação poderá ser proposta, para o proponente

\footnotetext{
${ }^{349}$ Cf. José Jairo Gomes, Direito eleitoral, p. 414.

${ }^{350}$ Corrobora com esta afirmação Luiz Carlos dos Santos Gonçalves, procurador-regional eleitoral da Procuradoria Regional Eleitoral de São Paulo, em entrevista dada ao autor deste trabalho em 9.12.2009.

${ }^{351}$ Cf. Wagner Bispo da Cunha, "O artigo 30-A e as suas implicações. Arrecadação, gastos e prestação de contas de campanha eleitoral - Eleições 2008”, p. 20.
} 
será mais interessante apresentar ação de impugnação de mandato eletivo - obviamente se houver também indícios de abuso do poder econômico, fraude ou corrupção - pois em caso de futura condenação poderá conseguir não só a perda do mandato do infrator, mas também a declaração de sua inelegibilidade pelo prazo de três anos.

\subsection{Lei dos Partidos Políticos (Lei n. 9.096/95)}

\subsubsection{Finanças e contabilidade partidárias}

A Lei dos Partidos Políticos traz regras sobre a administração dos recursos financeiros dos partidos políticos, recursos estes de origem pública ou privada. Os seus estatutos, inclusive, obrigatoriamente devem dispor sobre regras que disciplinem as finanças e a contabilidade partidária e eleitoral, conforme prevê o art. 15, incisos VII e VIII $^{352}$, da LPP

Estas normas devem estabelecer limites para as contribuições por partes dos filiados e definir as outras fontes de receita para os partidos. Ademais, há também a determinação de que os estatutos contenham disposições sobre a distribuição de recursos do Fundo Partidário entre seus órgãos nacional, estaduais e municipais.

Os Estatutos dos partidos políticos registrados no TSE prevêem, em respeito ao determinado no artigo acima citado, os seguintes assuntos relacionados à administração financeira: (i) administração do patrimônio do partido; (ii) contribuição financeira obrigatória por parte dos filiados, com adoção de parâmetros financeiros definindo o valor a ser doado, em especial entre os filiados ocupantes de cargos de confiança na Administração Pública ou que exercem mandato eletivo; (iii) normas de contabilização e administração dos recursos do partido; (iv) regras para as doações recebidas conforme permitido pela LPP ou pela LE; (v) normas de distribuição dos recursos monetários

\footnotetext{
352 “Art. 15. O Estatuto do partido deve conter, entre outras, normas sobre:

(...)

VII - finanças e contabilidade, estabelecendo, inclusive, normas que os habilitem a apurar as quantias que os seus candidatos possam despender com a própria eleição, que fixem os limites das contribuições dos filiados e definam as diversas fontes de receita do partido, além daquelas previstas nesta Lei;

VIII - critérios de distribuição dos recursos do Fundo Partidário entre os órgãos de nível municipal, estadual e nacional que compõem o partido".
} 
(doações, contribuições, rendimentos, montante do Fundo Partidário) entre os diretórios nacional, estaduais e municipais.

Determina também a LPP a obrigatoriedade dos partidos políticos manterem, em todos os seus órgãos, escrituração contábil, para que se possa ter ciência da origem de seus recursos e o destino de seus gastos. O dispositivo da LPP (art. 30 353 ) atende à determinação constitucional do dever de os partidos políticos prestarem contas à Justiça Eleitoral, conforme ditame do art. 17, inciso III da Constituição ${ }^{354}$.

Os partidos devem prestar contas à Justiça Eleitoral todo ano, no prazo máximo de 30 de abril do ano seguinte do exercício findo a ser controlado (art. 32, caput). Os balanços contábeis devem ser enviados no prazo acima pelo respectivo órgão da seguinte forma: o órgão nacional presta contas ao TSE; os órgãos estaduais ao respectivo Tribunal Regional Eleitoral e os órgãos partidários municipais devem apresentar suas contas ao Juiz Eleitoral do respectivo município (art. 32, $\S 1^{\circ}$ ). Recebidas as prestações de contas, deve a Justiça Eleitoral publicá-las na Imprensa Oficial. Não havendo imprensa oficial no município, os balanços serão afixados no próprio Cartório Eleitoral (art. 32, $\S 2^{\circ}$ ).

Em ano eleitoral, porém, os partidos devem prestar contas à Justiça Eleitoral de modo mais célere, para que se possa haver um controle maior dos atos partidários referentes às campanhas eleitorais. Assim, determina o $\S 3^{\circ}$ do art. 32 da LPP que os partidos devem enviar balancetes em periodicidade mensal entre os quatro meses anteriores e os dois meses posteriores à realização do pleito. Todos os balanços, em suas modalidades anual ou mensal, se for o caso, devem conter (art. 33): (i) valores recebidos do Fundo Partidário e respectivos gastos; (ii) origem e valor das contribuições e das doações recebidas; (iii) despesas de caráter eleitoral (ou seja, no período de campanha),

\footnotetext{
353 “Art. 30. O partido político, através de seus órgãos nacionais, regionais e municipais, deve manter escrituração contábil, de forma a permitir o conhecimento da origem de suas receitas e a destinação de suas despesas".

354 “Art. 17. É livre a criação, fusão, incorporação e extinção de partidos políticos, resguardados a soberania nacional, o regime democrático, o pluripartidarismo, os direitos fundamentais da pessoa humana e observados os seguintes preceitos:

(...)

II - proibição de recebimento de recursos financeiros de entidade ou governo estrangeiros ou de subordinação a estes;

III - prestação de contas à Justiça Eleitoral”.
} 
despesas estas especificadas e com as respectivas comprovações dos gastos, com especial ênfase nos dispêndios relativos à propaganda eleitoral (programa de rádio e televisão, propaganda em geral, publicações, comícios, infra-estrutura e demais atos de campanha).

Cabe à Justiça Eleitoral realizar a fiscalização sobre as prestações de contas partidárias e despesas feitas pelo partido durante suas campanhas eleitorais, devendo realçar na fiscalização se há veracidade na movimentação financeira declarada - com enfoque também nos gastos feitos nas campanhas - verificando se os partidos constituíram comitês para a administração dos recursos de campanha (comitês formados por dirigentes partidários, que eventualmente responderão civil e criminalmente em caso de anormalidades) e se mantiveram escrituração contábil de todo o montante circulado nas campanhas. Caso seja necessário, a Justiça Eleitoral pode requisitar técnicos do Tribunal de Contas da União ou dos Estados para este trabalho (art. 34).

Havendo denúncia advinda de filiado ou delegado de qualquer partido ou representação do Ministério Público Eleitoral ou havendo iniciativa do Corregedor do respectivo tribunal eleitoral, o TSE e os TRE's deverão determinar a análise da prestação de contas eventualmente maculada, para que se apure se houve ato violador das disposições legais e/ou estatutárias relativas às finanças partidárias. Para melhor análise, garante o texto do art. 35 da LPP a possibilidade de quebra do sigilo bancário das contas do partido denunciado, com o intuito de melhor esclarecimento ou apuração da denúncia.

Qualquer legenda pode analisar as prestações de contas dos outros partidos, havendo o prazo de 15 dias para tanto assim que forem publicadas as prestações. Feita a análise, se houver o interesse em face de eventual irregularidade, pode o partido impugnar as prestações em até cinco dias, em petição com indicação de provas e requerendo abertura de investigação para a apuração de infração legal e/ou estatutária em relação às finanças do partido acusado (art. 35, parágrafo único). 
A LPP traz em seu art. $31^{355}$ a relação das fontes de doações vedadas, entre elas: (i) entidade ou governo estrangeiro, em conformidade ao texto constitucional, em seu art. 17, inciso II; (ii) autoridade ou órgãos públicos, excepcionando-se à possibilidade do Fundo Partidário, que será estudado no próximo item deste trabalho; (iii) entidades da Administração Pública indireta (autarquias e fundações públicas, por exemplo) ou que tenham o poder público como financiador (sociedades de economia mista) e (iv) entidade de classe ou sindical.

As três últimas possibilidades estão no rol de fontes vedadas pelo fato de a doação de dinheiro público para partidos políticos constituir afronta aos princípios constitucionais da impessoalidade, da moralidade administrativa e da igualdade entre os candidatos. No caso das pessoas jurídicas de direito privado que recebem recursos públicos, há também a vedação pelo fato de ser impossível saber com precisão se os recursos eventualmente doados tinham origem pública ou privada.

Quanto à proibição de recebimento de recursos advindos de partidos ou governos estrangeiros, protege-se assim a soberania nacional, conforme determinado no art. 17, caput, da Constituição. Ressalte-se que a norma em comento não impede que os partidos brasileiros tenham relações com legendas de outros países, já que pode haver afinidades de caráter ideológico entre os dois partidos, por exemplo. Esta relação não caracteriza necessariamente uma relação de subordinação, mas sim o caráter global de algumas ideologias políticas presentes nas mais diversas nações ${ }^{356}$. Fora as vedações aqui apresentadas, os partidos políticos podem receber recursos advindos de pessoas físicas e jurídicas (art. 39).

Havendo irregularidades, a legenda poderá sofrer sanções de caráter financeiro, dependendo do tipo de infração cometida. Se o partido não esclarecer a origem de um

\footnotetext{
355 “Art. 31. É vedado ao partido receber, direta ou indiretamente, sob qualquer forma ou pretexto, contribuição ou auxílio pecuniário ou estimável em dinheiro, inclusive através de publicidade de qualquer espécie, procedente de:

I - entidade ou governo estrangeiros;

II - autoridade ou órgãos públicos, ressalvadas as dotações referidas no art. 38;

III - autarquias, empresas públicas ou concessionárias de serviços públicos, sociedades de economia mista e fundações instituídas em virtude de lei e para cujos recursos concorram órgãos ou entidades governamentais;

IV - entidade de classe ou sindical".

${ }^{356}$ Cf. Orides Mezzaroba, Partidos políticos: princípios e garantias constitucionais, Lei 9.096/95 anotações jurisprudenciais. Curitiba: Juruá, 2008, p. 37.
} 
recurso financeiro recebido, o repasse do seu montante do Fundo Partidário fica suspenso até que seja esclarecida a origem do recurso recebido (art. $36, \S 1^{\circ}$ )

Valores recebidos cuja origem é uma das fontes vedadas pelo art. 31 enseja o não recebimento do montante do Fundo Partidário por um ano (art. 36, $\S 2^{\circ}$ ). Se o partido tiver suas contas desaprovadas total ou parcialmente - ou se simplesmente não prestá-las - haverá também a suspensão do Fundo Partidário (art. $37^{357}$ ).

Se a Justiça Eleitoral entender necessário, pode o partido sofrer diligência para que se amealhem melhores informações para o julgamento das contas, ou até para o saneamento destas contas.

A pena de suspensão do Fundo Partidário deve ser imposta ao respectivo órgão infrator. Por exemplo, se o Diretório Municipal de Campinas foi o infrator, somente ele deixará de receber sua quota do Fundo Partidário, não havendo sanção aos outros diretórios partidários (art. 37, $\S 2^{\circ}$ ).

A lei era omissa quanto ao prazo de referida suspensão até o advento da Lei n. $12.034 / 09$, que inclui o $\S 3^{\circ}$ neste artigo que prevê o período de um a doze meses de suspensão, devendo o juiz aplicar a punição de forma "proporcional e razoável". Continua omissa, porém, no caso de o partido não apresentar as contas, eis que o prazo

\footnotetext{
357 “Art. 37. A falta de prestação de contas ou sua desaprovação total ou parcial implica a suspensão de novas cotas do Fundo Partidário e sujeita os responsáveis ás penas da lei.

$\S 1^{\circ}$. A Justiça Eleitoral pode determinar diligências necessárias à complementação de informações ou ao saneamento de irregularidades encontradas nas contas dos órgãos de direção partidária ou de candidatos. $\S 2^{\circ} \mathrm{A}$ sanção a que se refere o caput será aplicada exclusivamente à esfera partidária responsável pela irregularidade.

$\S 3^{\underline{0}}$ A sanção de suspensão do repasse de novas quotas do Fundo Partidário, por desaprovação total ou parcial da prestação de contas de partido, deverá ser aplicada de forma proporcional e razoável, pelo período de 1 (um) mês a 12 (doze) meses, ou por meio do desconto, do valor a ser repassado, da importância apontada como irregular, não podendo ser aplicada a sanção de suspensão, caso a prestação de contas não seja julgada, pelo juízo ou tribunal competente, após 5 (cinco) anos de sua apresentação $\S 4^{\circ}$ Da decisão que desaprovar total ou parcialmente a prestação de contas dos órgãos partidários caberá recurso para os Tribunais Regionais Eleitorais ou para o Tribunal Superior Eleitoral, conforme o caso, o qual deverá ser recebido com efeito suspensivo.

$\S 5^{\mathrm{o}}$ As prestações de contas desaprovadas pelos Tribunais Regionais e pelo Tribunal Superior poderão ser revistas para fins de aplicação proporcional da sanção aplicada, mediante requerimento ofertado nos autos da prestação de contas.

$\S 6^{\circ}$ O exame da prestação de contas dos órgãos partidários tem caráter jurisdicional”.
} 
da suspensão do Fundo é mencionado no texto do parágrafo somente se houver "desaprovação total ou parcial da prestação de contas do partido".

Outra novidade é o prazo prescricional: se não julgada a prestação de contas em cinco anos após sua apresentação pelo partido, não pode mais o partido sofrer a punição de suspensão de sua cota do Fundo Partidário.

A Lei n. 12.034/09 trouxe outros novos parágrafos ao art. 37 da LPP. Entre os novos dispositivos, há a previsão de recurso contra a decisão que desaprovar total ou parcialmente as contas, sendo que o recurso deve ser recebido sempre com efeito suspensivo (art. 37, $\S 4^{\circ}$ ). Isso significa que somente havendo o trânsito em julgado da decisão sobre a prestação de contas condenando o partido à suspensão do Fundo Partidário é que a pena poderá ser aplicada, fato este que somado ao prazo prescricional previsto no texto do $\S 3^{\circ}$ in fine, pode significar a impunidade de muitas das eventuais irregularidades eventualmente cometidas.

No mesmo espírito dos $\S \S 3^{\circ}$ e $4^{\circ}$, há também a possibilidade legal de revisão das prestações de contas desaprovadas, no intuito de rever a punição aplicada em caso de condenação, para que a proporcionalidade na aplicação da pena prevaleça (art. 37, § $\left.5^{\circ}\right)$.

Por fim, a Lei n. 12.034/09 deu à análise da prestação de contas dos órgãos partidários o caráter jurisdicional (art. 37, $\S 6^{\circ}$ ). Até então, está análise tinha caráter administrativo, não sendo possível ao partido infrator recorrer de decisão negativa ao TSE e tampouco ao STF, conforme entendimento jurisprudencial.

\subsubsection{Fundo Partidário}

Em atendimento ao disposto no art. $17, \S 3^{\circ}$ da Constituição, a LPP traz as regras que disciplinam o Fundo Especial de Assistência Financeira aos Partidos Políticos (abreviado pela própria lei para Fundo Partidário, conforme art. 38, caput).

Constitui o Fundo Partidário a única forma vigente na legislação partidárioeleitoral brasileira de financiamento da atividade político com recursos públicos de caráter direito. Ou seja, os recursos são disponibilizados diretamente na conta bancária 
do partido político, devendo a legenda decidir os destinos desses recursos, respeitandose os parâmetros legais que serão analisados adiante. Assevere-se que o Fundo Partidário também prevê entre seus recursos eventuais doações com origem privada. Porém, tal fato jamais ocorreu, pelos motivos explanados em seguida.

Os valores que são distribuídos aos partidos pelo Fundo Partidário têm várias origens, entre elas: (i) multas e penalidades pecuniárias aplicadas em atendimento à legislação eleitoral; (ii) os recursos financeiros que lhe são destinados por lei; (iii) doações de pessoa física ou jurídica feitas diretamente na conta bancária do Fundo; (iv) dotação orçamentária da União em valor nunca inferior ao de $\mathrm{R} \$ 0,35$ por eleitor (o número de eleitores para este cálculo é o número de pessoas alistadas na Justiça Eleitoral em 31 de dezembro do ano anterior ao feitura da lei orçamentária).

Interessante ressaltar as grandes diferenças entre as diversas origens que constituem o Fundo Partidário. Ter multas eleitorais como origem (art. 38, inciso I) significa que a lei prevê um autofinanciamento dos partidos políticos.

Já o inciso II, que tratada possibilidade de recursos financeiros estabelecidos em lei, trata-se de letra morta, eis que não há nenhuma outra lei que preveja outros recursos ao partido político.

Mesma situação encontra-se o inciso III, que dá a possibilidade de uma pessoa jurídica ou física doar recursos diretamente ao Fundo. Pergunta-se: quem terá interesse em doar recurso que será dividido entre as 27 legendas registradas no TSE? Se a pessoa física ou jurídica estiver interessada em incrementar financeiramente um ou até mais partidos, o fará diretamente, evitando-se assim que o recurso seja dividido inclusive entre os adversários da legenda de sua preferência.

Já o inciso IV é o mais relevante, eis que ele é o que garante boa parte dos recursos aos partidos políticos. José Bispo Sobrinho, ao ressaltar a importância da existência do Fundo Partidário, o critica também ao dizer que as quantias repassadas "são tão irrisórias que deixam muito a desejar como assistência financeira ${ }^{358, " . ~ N o ~}$

\footnotetext{
${ }^{358}$ José Bispo Sobrinho, Comentários à lei orgânica dos partidos políticos. Brasília: Brasília Jurídica, 1996, p. 84. Mesma opinião tem Carlos Velloso e Walber Agra, conforme trecho a seguir: "A utilização
} 
entanto, ao se analisar a quantia repassada pelo TSE aos partidos em 2008, vê-se que não se trata de valores insignificantes, pelo contrário: o Tesouro Nacional repassou ao TSE em referência à hipótese do inciso IV o valor de R\$135.614.982,00, enquanto que os partidos se utilizaram de $\mathrm{R} \$ 34.398 .112,77$ advindos das multas recolhidas pela Justiça Eleitoral $^{359}$.

O montante relativo ao Fundo Partidário deve estar previsto na lei orçamentária anual, mais especificamente no anexo da lei referente ao Poder Judiciário, na dotação referente ao TSE (art. 40, caput). Este montante será dividido em doze parcelas mensais, sendo responsabilidade do Tesouro Nacional a realização do depósito mensalmente em conta bancária no Banco do Brasil específica do TSE para este fim. Na mesma conta devem ser depositadas as quantias relativas à arrecadação de multas e/ou outras penalidades pecuniárias aplicadas em decisões condenatórias relativas ao descumprimento de normas previstas na legislação eleitoral.

Feito o depósito do valor do Fundo Partidário pelo Tesouro Nacional, o TSE tem cinco dias para fazer a distribuição entre os órgãos nacionais partidários, com a seguinte distribuição (art. 41-A da LPP ${ }^{360}$ ):

a) $5 \%$ do montante serão divididos igualitariamente entre todos os partidos registrados no TSE;

b) $95 \%$ do montante serão divididos entre todos os partidos registrados no TSE, de forma proporcional à votação obtida por cada um deles na última eleição para a Câmara dos Deputados.

Este artigo foi incluído na LPP pela Lei n. 11.459/07, em rápida resposta às decisões expedidas pelo STF sobre a inconstitucionalidade da cláusula de desempenho eleitoral contida no art. 13 da LPP ${ }^{361}$. Nas duas decisões unânimes do Pleno do STF, os

do Fundo Partidário (...) não supre as necessidades básicas de manutenção financeira da campanha, muito menos possibilita suportar os gastos de campanha" (Carlos Mário da Silva Velloso e Walber de Moura Agra, Elementos de direito eleitoral, p. 223).

359 Disponível em: < http://www.tse.jus.br/internet/partidos/fundo_partidario/2008.htm>. Último acesso em 10.12.2009.

360 “Art. 41-A. 5\% (cinco por cento) do total do Fundo Partidário serão destacados para entrega, em partes iguais, a todos os partidos que tenham seus estatutos registrados no Tribunal Superior Eleitoral e $95 \%$ (noventa e cinco por cento) do total do Fundo Partidário serão distribuídos a eles na proporção dos votos obtidos na última eleição geral para a Câmara dos Deputados".

${ }^{361}$ ADI 1351-3 e ADI 1354-8, j. em 07.12.2006, DJ 30.03.2007, Rel. Min. Marco Aurélio. 
incisos I e II do art. $41^{362}$ também foram julgados inconstitucionais, por desrespeito aos princípios constitucionais do pluralismo político e da isonomia.

Os incisos julgados inconstitucionais previam uma distribuição draconiana dos recursos do Fundo Partidário: 1\% do montante distribuído igualitariamente entre todos os partidos registrados no TSE e 99\% do montante distribuídos entre os partidos com funcionamento parlamentar (portanto, até 2006, os partidos com representantes na Câmara dos Deputados), sendo esses $99 \%$ divididos na proporção dos votos obtidos na última eleição para a Câmara.

Ante a divisão acima, os partidos que não conseguissem eleger ao menos um deputado federal teria apenas aproximadamente 0,037\% do Fundo Partidário (levandose em conta o número de 27 partidos registrados no TSE). O Ministro Cezar Peluso, em seu voto, critica o caráter "assaz restritivo" dessa distribuição, com forte prejuízo aos partidos pequenos e às legendas em formação, sendo elas condenadas a "uma morte lenta e segura", pois não terão "as condições mínimas a concorrer no prélio eleitoral subseqüente em regime de igualdade com as demais agremiações partidárias"363.

Prevê também a LPP a obrigatoriedade de a movimentação dos recursos do Fundo Partidário ocorrer em bancos públicos, controlados pelo Poder Público Federal ou Estadual (art. 43). José Bispo Sobrinho afirma que o dispositivo advém do dispositivo constitucional que determina a realização em estabelecimentos bancários oficiais das movimentações de recursos públicos (art. 164, § $3^{\circ}$ da Constituição) ${ }^{364}$.

O art. 42 da LPP prevê a obrigatoriedade do retorno ao Fundo Partidário de quantia relativa a órgão partidário que foi cancelado ou em caso de caducidade. Essas possibilidades ocorrem, por exemplo, quando um diretório municipal não atinge mais o

\footnotetext{
362 “Art. 41. O Tribunal Superior Eleitoral, dentro de cinco dias, a contar da data do depósito a que se refere $0 \S 1^{\circ}$ do artigo anterior, fará a respectiva distribuição aos órgãos nacionais dos partidos, obedecendo aos seguintes critérios:

I - um por cento do total do Fundo Partidário será destacado para entrega, em partes iguais, a todos os partidos que tenham seus estatutos registrados no Tribunal Superior Eleitoral;

II - noventa e nove por cento do total do Fundo Partidário serão distribuídos aos partidos que tenham preenchido as condições do art. 13, na proporção dos votos obtidos na última eleição geral para a Câmara dos Deputados".

${ }_{363}$ ADI 1351, Voto do Min. Cezar Peluso, p. 150.

${ }^{364}$ Cf. José Bispo Sobrinho, Comentários à lei orgânica dos partidos políticos. p. 90.
} 
número mínimo de filiados (condição especificada em Estatuto para sua existência dentro da hierarquia partidária) ou quando há o fim do mandato de um quadro diretivo do órgão partidário sem haver a respectiva renovação por meio da democracia interna da legenda.

Essas possibilidades tornam-se mais preocupantes em caso de ocorrer no órgão nacional do partido. Se tal fato ocorrer, o partido não deixa de existir, mas até nova eleição para a formação do corpo diretivo, a legenda ficará sem membros designados para a administração financeira do partido ${ }^{365}$.

A LPP determina, em seu art. 44, quais são os tipos de gastos a serem realizados pelos partidos com os recursos do Fundo Partidário, entre eles: (i) manutenção das sedes e de seus serviços, além do pagamento de pessoal; (ii) propaganda doutrinária e política; (iii) no alistamento e nas campanhas eleitorais; (iv) na criação e manutenção de instituto de fundação de pesquisa e de doutrinação e educação política; e (v) criação e manutenção de programas para promover a participação política das mulheres.

O inciso I prevê gastos basicamente com a infra-estrutura permanente do partido. A Lei n. 12. 034/09, porém, mudou a redação do artigo, ao prever que o gasto com pessoal pode atingir até $50 \%$ dos recursos recebidos do Fundo Partidário (antes, o limite era de $20 \%$ ).

A mudança reconhece a importância da manutenção de uma densa infraestrutura nos partidos políticos, em especial de funcionários que possam realizar um trabalho de fortalecimento dos vínculos do partido com a sociedade ou assessorar os filiados que exercem mandatos eletivos em suas responsabilidades, além de planejar os rumos político-eleitorais a serem tomados pelo partido.

Angelo Panebianco reconhece a importância de um forte corpo burocrático dos partidos, afirmando inclusive que o número de funcionários - em combinação com outros fatores - é a "espinha dorsal” da distinção entre partidos fortes e fracos, pois esse

${ }^{365}$ Cf. José Bispo Sobrinho, Comentários à lei orgânica dos partidos políticos, p. 89. 
corpo burocrático traz melhores condições para principalmente o partido atingir um alto nível de "coerência estrutural interna ${ }^{366 "}$ ".

A possibilidade de os partidos políticos se fortalecerem graças a um extenso corpo de funcionários é também reconhecida por Jairo Nicolau. Ao detectar o PT e o PSDB como as duas legendas mais fortes e programáticas em âmbito nacional (são as duas únicas que apresentaram candidatos em todas as eleições presidenciais ocorridas após a redemocratização), o autor rememora que tal fato se deu também pelo fato de em cada eleição presidencial os partidos terem a necessidade de elaborar um programa de governo, sendo mobilizados seus membros para a consecução deste trabalho, gerando uma coerência programática interna ${ }^{367}$.

Os recursos do Fundo Partidário também terão como alvo a manutenção de fundações ou institutos de pesquisa para a doutrinação e educação política. As fundações/institutos partidárias também têm o objetivo de ser um meio de fortalecimento dos vínculos entre os partidos e as sociedades. Para tanto, podem as fundações/institutos realizar cursos, palestras, reunião de estudantes, acadêmicos e demais interessados em política para discutir os rumos do país em seus mais variados aspectos, fazendo com que mais pessoas possam se interessar pelo trabalho político realizados pelos partidos ${ }^{368}$.

Os recursos destinados às fundações/institutos deverão ser de, no mínimo, $20 \%$ do montante recebido do Fundo Partidário. Elas são pessoas jurídicas de direito privado, com autonomia para contratar com instituições públicas e privadas, prestar serviços e manter estabelecimentos de acordo com suas finalidades, podendo, ainda, manter intercâmbio com instituições não nacionais (art. 53 da LPP).

A Lei n. 12.034/09 acresceu à LPP o inciso V no art. 44, determinando a criação e manutenção de programas de promoção e difusão da participação política feminina. $\mathrm{O}$

\footnotetext{
${ }^{366}$ Angelo Panebianco. Modelos de partido: organização e poder nos partidos políticos, (tradução de Denise Agostinetti). São Paulo: Martins Fontes, 2005, p. 435.

${ }^{367}$ Cf. Jairo Nicolau, "Notas sobre as eleições de 2002 e o sistema partidário brasileiro", p. 15.

${ }^{368}$ Cf. Daniel Gustavo Falcão Pimentel dos Reis, "Os partidos políticos e as organizações não governamentais: proposta de trabalho conjunto", in Instituto Tancredo Neves - Partido da Frente Liberal, Prêmio Luís Eduardo Magalhães - 8a edição ano 2005, Brasília: ITN, 2006, p. 31-32.
} 
percentual de recursos do Fundo Partidário a ser destinado a estes programas fica a critério do partido, mas deve respeitar o mínimo de 5\% fixado legalmente.

Esse dispositivo veio em reforço ao previsto no art. $10, \S 3^{\circ}$ da LE, que determina ao partido político o preenchimento de ao menos $30 \%$ das candidaturas nas eleições proporcionais para cada sexo. Esse dispositivo, no entanto, é sistematicamente descumprido, sob a alegação de que não há número suficiente de mulheres filiadas para que a cota seja cumprida. Assim sendo, os programas previstos no inciso V do art. 44 da LPP, pagos com recursos do Fundo Partidário, vêm, portanto, assegurar uma possibilidade de crescimento no número de filiados do sexo feminino, meio este capaz de incentivar uma maior participação das mulheres na seara política ${ }^{369}$.

Se o partido descumprir o mínimo determinado aos programas de incentivo da participação feminina, terá que no ano seguinte acrescer 2,5\% do Fundo Partidário para essa destinação, não havendo outra possibilidade de uso desse recurso (art. 44, $\S 5^{\circ}$, incluído pela Lei n. 12.034/09).

$\mathrm{O}$ art. 44 também prevê o uso dos recursos do Fundo Partidário na propaganda política e nas campanhas eleitorais. No entanto, nota-se que essas destinações terão poucos recursos, já que somados os percentuais mínimos destinados às fundações $(20 \%$, no mínimo), aos programas de difusão da participação feminina na política (5\%, no mínimo) e os gastos com sua infra-estrutura (com destaque ao pagamento de pessoal, não incluídos nesta dotação os encargos e os tributos de qualquer natureza, conforme dispõe o $\S 4^{\circ}$ do art. 44, incluído pela Lei n. 12.034/09), pouco sobrará para a disputa eleitoral ou para sua propaganda.

As despesas referentes aos incisos I (infra-estrutura e pessoal) e IV (manutenção das fundações/institutos) deverão ser discriminadas pormenorizadamente nas prestações de contas, de modo que a Justiça Eleitoral possa fazer efetivo controle dos limites máximo (inciso I) e mínimo (inciso IV) determinado legalmente, conforme ditame do $§$ $1^{\circ}$ do art. 44. O texto também deveria incluir maior controle sobre os recursos destinados aos programas de incentivo à participação feminina na política, eis que

${ }^{369}$ Cf. Vera Lúcia Rocha Souza Jucovsky, Representação política da mulher. São Paulo: Juarez de Oliveira, 2000, p. 41. 
também há um piso legal para tanto. A Justiça Eleitoral pode, a qualquer tempo, realizar investigação sobre a aplicação dos recursos advindos do Fundo Partidário (art. 44, § $2^{\circ}$ ).

A LPP também prevê a desnecessidade de os partidos realizarem procedimentos licitatórios para a aplicação dos recursos do Fundo Partidário (art. 44, § $3^{\circ}$ ). Apesar de os recursos serem públicos, os partidos políticos são pessoas jurídicas de direito privado (art. $1^{\mathrm{o}}$ da LPP), com autonomia para determinar suas regras de organização e funcionamento (art. $3^{\circ}$ da LPP).

As doações feitas por pessoas físicas ou pessoas jurídicas também são permitidas aos partidos políticos, com exceção às entidades previstas no art. 31 da LPP (art. 39). Estas doações não necessariamente são centralizadas no órgão partidário nacional, ou seja, o doador pode realizar sua contribuição diretamente ao órgão partidário de seu interesse, seja ele de abrangência nacional, estadual ou municipal, devendo o órgão receptor fazer a devida contabilização, não só à Justiça Eleitoral, mas também ao órgão partidário imediatamente superior, se houver. Se houver doação de bens ou de valores estimados, deve o partido fazer sua contabilização em valores em moeda corrente. Havendo doação em dinheiro, a transferência dever ser feita obrigatoriamente por cheque cruzado endossado ao partido ou depósito bancário na conta da legenda.

A Lei n. 12.034/09 incluiu o $\S 5^{\circ}$ neste art. 39 da LPP, deixando claro que o partido pode aplicar essas doações nas campanhas eleitorais, desde que essas doações respeitem os limites de doações às pessoas físicas e jurídicas determinados pela LE (art. $23, \S 1^{\circ}$ e art. $81, \S 1^{\circ}$, ambos da LE), além de não ter origem nas fontes de doações vedadas às campanhas eleitorais (art. 24 da LE). Na verdade, sempre houve a possibilidade de os partidos receberem doações e repassarem os recursos doados às suas campanhas eleitorais.

Esta possibilidade, porém, é criticada na forma que a legislação atual dispõe, eis que é bastante interessante ao doador e ao candidato que a doação para as campanhas eleitorais sejam feitas pelo partido. Enquanto que o candidato deve prestar contas das doações feitas diretamente a ele no prazo de um mês após a eleição, as doações feitas aos partidos políticos somente serão de conhecimento público em 30 de abril do ano 
seguinte à eleição. Este prazo evita que os eleitores e os candidatos adversários saibam quem está doando para quais candidatos.

Ademais, ao doar ao partido, também se torna impossível para a sociedade saber que doação foi dirigida a um candidato específico ou não, pois ao receber essas doações, o partido pode repassar para diversos candidatos. Na prática, não é possível contabilizar quais candidaturas o doador quis incentivar financeiramente, prejudicando assim sobremaneira a transparência das campanhas eleitorais e das relações entre os partidos políticos e a sociedade, principalmente entre àqueles que fazem doações partidárioeleitorais. Caso não haja estabelecimento bancário oficial no Município, porém, é permitida a movimentação dos recursos do Fundo Partidário em bancos privados.

\subsubsection{Horário Partidário e Eleitoral Gratuito}

O Horário Partidário Gratuito e o Horário Eleitoral Gratuito, previstos no art. 17, $\S 3^{\circ}$ da Constituição, são formas de financiamento da atividade política de caráter público indireto presentes na legislação eleitoral brasileira.

Os horários gratuitos são de caráter público porque é o Estado quem paga às emissoras de rádio e televisão por sua veiculação, e não os partidos políticos ou os candidatos, que têm acesso aos horários de forma gratuita (por isso a denominação). Trata-se de financiamento público da atividade política de forma indireta pelo fato de a movimentação financeira referente aos custos dos horários gratuitos não passarem pelas contas bancárias dos partidos e dos candidatos em nenhuma hipótese: trata-se de um mecanismo de compensação fiscal do Imposto de Renda a ser pago pelas emissoras.

A fundamental diferença entre o horário eleitoral e o horário partidário assentase no fato de que o primeiro é veiculado somente durante o período de campanha eleitoral. No primeiro turno, haverá propaganda eleitoral no rádio e na televisão nos 45 dias anteriores à antevéspera da eleição (art. 47, caput, da LE); havendo segundo turno, a propaganda eleitoral gratuita ocorrerá a partir de quarenta e oito horas da proclamação do resultado do primeiro turno e a antevéspera da eleição (art. 49, caput, da LE). Já o horário partidário gratuito é veiculado somente em períodos não-eleitorais, com o 
objetivo de difundir os programas e posições partidárias, além de informar sobre o trabalho realizado pelo partido e também fomentar a participação feminina na política (art. 45, incisos I, II, III e IV da LPP).

Conforme visto no item 2.1.3, trata-se do principal meio de propagação das propostas e promessas feitas tanto pelos partidos políticos como pelos candidatos. Porém, neste item, será analisada somente a forma como o Estado ressarce as emissoras e rádio e televisão pela veiculação das propagandas políticas e eleitorais. Roque Antonio Carrazza considera o mecanismo de compensação fiscal como correto, já que as emissoras têm prejuízos financeiros ao exibir a propaganda partidário-eleitoral, conforme o autor explica adiante

Todavia, na medida em que a Constituição Brasileira reconhece e garante o direito de propriedade (embora o submeta ao princípio da função social), é indiscutível que as emissoras de rádio e televisão têm que ser financeiramente compensadas pela perda de receita que a cedência de seus horários lhes acarreta. (...) Tais ônus deverão ser suportados pelo Estado, pois as propagandas beneficiam, como explicado, a sociedade em geral $^{370}$.

Ademais, ante a grande importância dessa modalidade de propaganda política, a legislação veda a compra por parte dos partidos ou dos candidatos de espaço para propaganda partidária ou eleitoral nas emissoras de rádio e televisão, no intuito de preservar a igualdade de condições entre os candidatos (art. $45, \S 6^{\circ}$ da LPP).

O direito à compensação fiscal garantido às emissoras está previsto no art. 52, parágrafo único da LPP (no caso do horário partidário gratuito) e no art. 99, caput, da LE (em se tratando de horário eleitoral gratuito).

Rogério Carlos Born aponta possível incompatibilidade entre o as normas que possibilitam o mecanismo da compensação fiscal para o ressarcimento das emissoras que veiculam compulsoriamente a propaganda política e o art. 66, $\S 1^{\circ}$ da Lei $n$. 8.383/91, que determina que somente possa ser feita compensação entre tributos da

\footnotetext{
${ }^{370}$ Roque Antonio Carrazza, Imposto sobre a renda: perfil constitucional e temas específicos. 2. ed., rev., ampl. e atual., São Paulo: Malheiros, 2006, p. 360.
} 
mesma espécie. Mas como a LPP e a LE foram editadas posteriormente, no caso em voga entende-se possível a compensação ${ }^{371}$.

O mecanismo de compensação fiscal em favor das emissoras de rádio e televisão consiste na "possibilidade de abatimento, da base de cálculo do tributo, dos valores monetários que, pela cessão de seus horários de programação, deixaram de receber $^{372}$ ".

Ressalte-se que mesmo no caso de a emissora não ter auferido lucro, mas sim prejuízos fiscais - não recolhendo nenhum valor a título de Imposto de Renda - a emissora deve ser ressarcida, pois sofreu perda de receita pelo fato de ser obrigada a veicular a propaganda partidário-eleitoral.

Para efeitos do cálculo do imposto e do direito de compensação, as emissoras devem excluir do seu lucro líquido, para efeito de cálculo do lucro real, todos os rendimentos que deixou de auferir por conta da veiculação da propaganda partidárioeleitoral.

Mas deve-se perguntar: no caso de exibição de propaganda em bloco (ou seja, em tempo contínuo), a emissora tem o direito de compensar por todo o tempo de exibição do bloco de propaganda política? A resposta é não.

$\mathrm{O}$ art. 124 do Código Brasileiro de Telecomunicações (Lei n. 4.117/62) dispõe que as emissoras devem ocupar com publicidade no máximo $25 \%$ do tempo total de suas programações. Assim sendo, numa transmissão de bloco de propaganda política de 50 minutos, por exemplo, o tempo a ser considerado para o cálculo é o de 12,5 minutos ( $25 \%$ de 50 minutos), e não o que a emissora pode utilizar cotidianamente - as emissoras normalmente veiculam mais propagandas comerciais em horários nobres que em horários com baixa audiência; e os horários considerados mais nobres são justamente aqueles em que a veiculação da propaganda partidário-eleitoral é obrigatória (dispõe na mesma forma o $\S 3^{\circ}$ do art. $1^{\circ}$ do Decreto $n$. 5.331/05, que regulamenta o art. 52 da LPP e também o art. 99 da LE).

\footnotetext{
${ }^{371}$ Cf. Rogério Carlos Born, "O direito à compensação fiscal pela propaganda política gratuita", in Informativo eleitoral, v. 16, p. 44-45.

${ }^{372}$ Roque Antonio Carrazza, Imposto sobre a renda: perfil constitucional e temas específicos, p. 361.
} 
Em caso de inserção (ou seja, propaganda partidária ou eleitoral exibida entre as outras peças de publicidade comercial da emissora), considera-se tempo efetivamente utilizado todo o tempo de veiculação da inserção.

Corrobora com o entendimento acima exposto Roque Antonio Carrazza, afirmando também que em respeito ao princípio da isonomia (art. $5^{\circ}$, inciso II e art. 150, inciso II da Constituição), todas as emissoras têm direito ao mesmo valor de abatimento, eis que as propagandas políticas gratuitas transmitidas em bloco têm o mesmo tempo de duração para todas as emissoras ${ }^{373}$.

$\mathrm{O}$ art. $1^{\circ}$, caput, do Decreto n. $5 \cdot 331 / 05^{374}$ determina que no cálculo que a emissora dever fazer para obter o valor a ser compensado em seu pagamento do Imposto de Renda, deve-se fazer a seguinte conta: valor do preço do espaço comercializável multiplicado pelo tempo que a emissora utilizaria em sua programação destinado à publicidade comercial. O resultado desta primeira conta multiplicado por oito décimos é o valor ${ }^{375}$

O $\S 1^{\circ}$ do art. $1^{\circ}$ define o preço do espaço comercializável como “o preço de propaganda da emissora, comprovadamente vigente no dia anterior à data de início da propaganda partidária ou eleitoral", devendo esse preço guardar proporcionalidade com o praticado nos trinta dias anteriores e com os trinta dias posteriores a esta data. Ante o disposto, cabe ao Fisco apenas "aferir a proporcionalidade entre os preços de tabela das propagandas convencionais com os efetivamente praticados, pela emissora 'trinta dias antes e trinta dias depois" ${ }^{, 376}$.

\footnotetext{
${ }^{373}$ Cf. Roque Antonio Carrazza, Imposto sobre a renda: perfil constitucional e temas específicos, p. 373

374 “'Art. $1^{\circ}$.As emissoras de rádio e televisão obrigadas à divulgação gratuita da propaganda partidária ou eleitoral poderão, na apuração do Imposto sobre a Renda da Pessoa Jurídica (IRPJ), excluir do lucro líquido, para efeito de determinação do lucro real, valor correspondente a oito décimos do resultado da multiplicação do preço do espaço comercializável pelo tempo que seria efetivamente utilizado pela emissora em programação destinada à publicidade comercial, no período de duração da propaganda eleitoral ou partidária gratuita".

${ }^{375}$ Assim, por exemplo, se uma emissora cobra $\mathrm{R} \$ 2.000,00$ por minuto para veiculação de publicidade comercial, e se for obrigada a disponibilizar 60 minutos seguidos para a propaganda política, ela poderá excluir do lucro real $\mathrm{R} \$ 24.000,00$, conforme seguinte cálculo: $(\mathrm{R} \$ 2.000,00 \times 15 \mathrm{~min}) \times 0,8=\mathrm{R} \$$ 24.000,00.

${ }^{376}$ Roque Antonio Carrazza, Imposto sobre a renda: perfil constitucional e temas específicos, p. 376.
} 
Carrazza ressalta que o preço do espaço comercializável deverá ser o valor mais alto que a emissora cobra para os anunciantes comerciais, vigorando assim o que se chama de tabela cheia, não se considerando, portanto, descontos eventualmente dados aos seus clientes nem as porcentagens pagas às agências de publicidade ${ }^{377}$.

\subsection{Código Eleitoral (Lei n. 4.737/65)}

Não há no texto do Código Eleitoral nenhum dispositivo que trate da arrecadação, administração de recursos para os partidos políticos, tampouco para as campanhas eleitorais. Também não há referência às prestações de contas eleitorais ou partidárias. Assim, deve-se o interesse na análise de dispositivos presentes no CE no que tange aos crimes eleitorais.

Dividindo-se as espécies de crimes eleitorais, chega-se aos crimes contra a fé pública eleitoral. Em um ambiente democrático, a fé e a confiança são imprescindíveis para que as eleições - momento de reflexão e decisão do eleitor sobre o futuro da sociedade e do Estado - transcorram da maneira mais limpa e autêntica possível ${ }^{378}$. Nesta espécie estão arrolados em especial os tipos penais eleitorais que tratam da falsificação de documentos públicos ou particulares para fins eleitorais.

Há, em se tratando da falsificação na seara eleitoral, três tipos penais que tratam do assunto: (i) falsificação de documento público para fins eleitorais (art. $348^{379}$ do CE); (ii) falsificação de documento particular para fins eleitorais (art. $349^{380}$ do CE) e. (iii) falsidade ideológica (art. $350^{381}$ do CE).

\footnotetext{
${ }^{377}$ Cf. Roque Antonio Carrazza, Imposto sobre a renda: perfil constitucional e temas específicos, p. 376.

${ }^{378}$ Cf. Suzana de Camargo Gomes, Crimes eleitorais, 3. Ed., rev., atual., e ampl., São Paulo: Revista dos Tribunais, 2008, p. 330-331.

379 "Art. 348. Falsificar, no todo ou em parte, documento público, ou alterar documento público verdadeiro, para fins eleitorais:

Pena - reclusão de dois a seis anos e pagamento de 15 a 30 dias-multa.

$\S 1^{\circ}$ Se o agente é funcionário público e comete o crime prevalecendo-se do cargo, a pena é agravada.

$\S 2^{\circ}$ Para os efeitos penais, equipara-se a documento público o emanado de entidade paraestatal inclusive Fundação do Estado".

380 "Art. 349. Falsificar, no todo ou em parte, documento particular ou alterar documento particular verdadeiro, para fins eleitorais:

Pena - reclusão até cinco anos e pagamento de 3 a 10 dias-multa".

381 "Art. 350. Omitir, em documento público ou particular, declaração que dele devia constar, ou nele inserir ou fazer inserir declaração falsa ou diversa da que devia ser escrita, para fins eleitorais:
} 
Os dois primeiros tipos tratam da falsidade do tipo material, ou seja, a criação ou a alteração de um documento público ou particular em sua forma. Trata-se de “adulteração, rasura, inclusão ou retirada de letras ou algarismos do documento"382. Já o terceiro tipo, a falsidade ideológica, diferencia-se pelo fato deste tipo caracterizar-se pela existência de documento que contém uma "menção inverídica (...) seu texto é falso ou omisso em relação à realidade que devia consignar ${ }^{383 "}$.

Em se tratando de arrecadação e administração de recursos de campanha eleitoral ou de partido político, o manejo de recursos fora da contabilização oficial (ou seja, angariar doações e aplicá-las sem qualquer menção na prestação de contas parcial ou final) - manejo esse conhecido popularmente como "caixa dois" - pode ser caracterizado como falsidade ideológica? Para se chegar a uma resposta a esta pergunta, é imprescindível uma análise mais profunda do tipo penal.

A primeira hipótese do tipo trata da omissão declaração em documento. Omitir tem o sentido de deixar de fazer algo, quando era dever do agente a fazer menção no documento do conteúdo que deixou de ser incluído. Já a segunda hipótese é a de inserir no documento declaração não verdadeira ou declaração diferente daquela que deveria ser mencionada. A terceira hipótese do tipo é a de fazer inserir, ou seja, um terceiro determinar a inclusão de declaração não verdadeira ou diferente daquele que deveria ser mencionada ${ }^{384}$.

Em se tratando de "caixa dois", a hipótese que se amolda é a primeira, já que o candidato, administrador de campanha ou dirigente partidário infrator omite a arrecadação realizada e também omite o gasto realizado com o montante coletado ocultamente, com o intuito de ludibriar a Justiça Eleitoral e seus adversários ao produzir documento (a prestação de contas) inverídico, com omissão de dados que dele deveriam constar (no caso, o recurso angariado e seu respectivo gasto).

Pena - reclusão até cinco anos e pagamento de 5 a 15 dias-multa, se o documento é público, e reclusão até três anos e pagamento de 3 a 10 dias-multa se o documento é particular.

Parágrafo único. Se o agente da falsidade documental é funcionário público e comete o crime prevalecendo-se do cargo ou se a falsificação ou alteração é de assentamentos de registro civil, a pena é agravada".

${ }^{382}$ Cf. Suzana de Camargo Gomes, Crimes eleitorais, p. 341.

${ }^{383}$ Cf. Suzana de Camargo Gomes, Crimes eleitorais, p. 341-342.

${ }^{384}$ Cf. Suzana de Camargo Gomes, Crimes eleitorais, p. 342-343. 
Joel Cândido, porém, afirma que o tipo ora estudado não abarca a prática de "caixa dois". Explica o autor que o candidato ou o administrador da campanha, no caso de campanhas eleitorais, que arrecadou recursos paralelamente à contabilização oficial, mas prestou contas "de todo o valor máximo que se propunha a receber, gastar e contabilizar, e que foi declarado por ocasião de seu pedido de registro, na forma do art. 18 , caput, da LE" não comete o crime de falsidade ideológica ${ }^{385}$.

O autor relaciona a prática do "caixa dois" ao limite máximo de gastos declarado pelo partido ou pelo candidato no momento do registro da candidatura, declaração de limite máximo essa determinada pelo art. 18 da $\mathrm{LE}^{386}$, que também prevê a aplicação de sanção extrapenal de multa em caso de descumprimento (art. $18, \S 2^{\circ}$ ), conforme se depreende do trecho a seguir:

Para que crime se pudesse falar, nesse caso, teria que haver tipicidade, punindo a existência de contabilidade paralela, ou dupla (“caixa 2"), e não única. Teria que haver figura típica punindo 'o gasto acima do valor máximo declarado no registro' (LE, art. 18, caput), o que, hoje, ainda não é crime eleitoral tipificado em norma penal alguma, não passando a conduta de mera infração extrapenal: LE, art. 18, § $2^{\text {o387. }}$.

$\mathrm{Na}$ jurisprudência, nota-se que há espaço para interpretações diametralmente diferentes: há acórdãos tanto para reconhecer a atipicidade da conduta como para o contrário, ou seja, dizendo que a arrecadação e administração de recursos não declaradas na prestação de contas amoldam-se ao previsto no art. 350 do CE.

No Recurso Especial Eleitoral n. 26.610, o TSE manteve decisão do TRE-SP que não reconhecia a tipicidade do ato de "caixa dois" pelo fato de a conduta de ocultar

\footnotetext{
${ }^{385}$ Cf. Joel J. Cândido. Direito penal eleitoral \& processo penal eleitoral. Bauru: EDIPRO, 2006, p. 413. 386 "Art. 18. No pedido de registro de seus candidatos, os partidos e coligações comunicarão aos respectivos Tribunais Eleitorais os valores máximos de gastos que farão por cargo eletivo em cada eleição a que concorrerem, observados os limites estabelecidos, nos termos do art. 17-A desta Lei.

$\S 1^{\circ}$ Tratando-se de coligação, cada partido que a integra fixará o valor máximo de gastos de que trata este artigo.

$\S 2^{\circ}$ Gastar recursos além dos valores declarados nos termos deste artigo sujeita o responsável ao pagamento de multa no valor de cinco a dez vezes a quantia em excesso".

${ }^{387}$ Joel J. Cândido, Direito penal eleitoral \& processo penal eleitoral, p. 413-414.
} 
na prestação de contas eventual doação recebida não ter finalidade eleitoral, conforme se depreende do trecho a seguir:

Com efeito, a rejeição da prestação de contas, decorrente de omissão em relação à despesa que dela deveria constar não implica, necessariamente, a caracterização do crime capitulado no art. 350 do CE. (...) Não há como reconhecer, na espécie, a finalidade eleitoral da conduta omissiva, elemento subjetivo do tipo penal em apreço, porquanto as contas são apresentadas à Justiça Eleitoral após a realização do pleito, estando ausente, portanto, a potencialidade lesiva para macular o processo eleitoral. Note-se que, em se tratando de norma penal, sua interpretação deve ser estrita, jamais extensiva. Se falsidade houver, será a prevista no direito penal comum ${ }^{388}$. (grifo nosso).

No entanto, em decisão monocrática expedida no Habeas Corpus n. 581 (julgado em 18.03.2008, DJ 03.04.2008), o Ministro Cezar Peluso não afastou a tipicidade da falsidade ideológica, reconhecendo que a omissão de declarações na prestação de contas pode configurar o crime de falsidade ideológica ${ }^{389}$.

Na decisão proferida no Habeas Corpus n. 482 há outra discussão interessante do TSE quanto à tipicidade do crime de falsidade ideológica na seara eleitoral. $\mathrm{O}$ fato concreto é que o candidato ora acusado não havia assinado a prestação de contas (somente o administrador da campanha o havia feito). O Ministro Relator originário Luiz Carlos Madeira entendeu que mesmo sem a assinatura do candidato, o mesmo deveria responder pelo crime, eis que houve ocultação de doações em sua prestação de contas, conforme trecho a seguir:

O fato de não ter assinado a prestação de contas não pode vir em proveito do candidato para eximir-se ou da ação de investigação judicial eleitoral, ou contra a diplomação, ou da impugnação de mandato eletivo ou da ação penal

\footnotetext{
${ }^{388}$ REspe n. 26.610, julgado em 8.5.2008, Rel. Min. Marcelo Henriques Ribeiro de Oliveira, DJ 29.5.2008. No mesmo sentido, REspe n. 35.518, julgado em 25.8.2009, Rel. Min. Félix Fischer, DJE 15.9.2009 e REspe n. 36.050, julgado em 24.11.2009, Rel. Min. Enrique Ricardo Lewandowski, DJE 30.11.2009.

${ }^{389}$ Ementa: “(...)AÇÃO PENAL. Prestação de contas de campanha. Suposta inserção de declaração falsa. Art. 350 do CE. Justa causa. Reconhecimento. A omissão e a inserção de informações falsas nos documentos de prestação de contas, dado o suposto montante de despesas não declaradas, configuram, em tese, o ilícito previsto no art. 350 do CE. 3. AÇÃO PENAL. Aprovação de contas no âmbito administrativo. Independência entre as esferas cível-eleitoral e penal. Precedente. "A eventual aprovação da prestação de contas, dado seu caráter administrativo, não impede a análise de fatos a ela relacionados em procedimento criminal que investigue a possível prática de crime eleitoral". (grifo nosso).
} 
correspondente. As omissões na prestação de contas estão relacionadas com fins eleitorais, tendo em vista que o volume dos gastos não declarados estaria a configurar ilícitos eleitorais, de cuja responsabilização ficaria o paciente ao $\operatorname{largo}{ }^{390}$.

A decisão do Plenário do TSE, porém, foi no sentido de que para a conduta ser típica o suposto infrator deve ter assinado a prestação de contas. Trecho do voto do relator designado, Ministro Marco Aurélio, resume o entendimento:

Separo a responsabilidade civil eleitoral, a responsabilidade administrativa, da responsabilidade penal. Não tenho como concluir pela prática do crime de falso em relação a um documento que não veio a ser subscrito por quem é acusado ${ }^{391}$.

Deve-se enfatizar que a proposta de reforma eleitoral apresentada pela Comissão de Notáveis do TSE em novembro de 2005 (estudada no item 2.2.2) apresenta uma nova tipificação exclusiva para o crime de "caixa dois", fato este que pode facilitar a interpretação de que o crime de falsidade ideológica previsto no art. 350 do CE não se amolda à conduta concernente em ocultar arrecadação e aplicação de recursos de campanha eleitoral na respectiva prestação de contas.

\subsection{Lei das Inelegibilidades (Lei Complementar n. 64/90)}

A Lei das Inelegibilidades tem como função estabelecer, em conformidade ao art. $14, \S 9^{\circ}$ da Constituição as hipóteses infraconstitucionais de inelegibilidade, ou seja, mesmo no caso de o candidato já postular as condições de elegibilidade (previstas no art. $14, \S 3^{\circ}$, quais sejam: nacionalidade brasileira, pleno exercício dos direitos políticos, alistamento eleitoral, domicílio eleitoral na circunscrição, filiação partidária e idade mínima na posse para o exercício do cargo), pode ele ser alijado das eleições caso possua alguma condição de inelegibilidade.

Há hipóteses de inelegibilidade no texto constitucional, entre elas a relação de parentesco ou a vedação do exercício de um terceiro mandato seguido no poder

\footnotetext{
${ }^{390}$ HC n. 482, j. 17.6.2004, Rel. Min. Luiz Carlos Madeira, Rel. designado Min. Marco Aurélio. DJ 27.8.2004.

${ }^{391}$ HC n. 482, j. 17.6.2004, Rel. Min. Luiz Carlos Madeira, Rel. designado Min. Marco Aurélio. DJ 27.8.2004.
} 
Executivo, mas esse item foca as duas hipóteses de inelegibilidade previstas na LI, eis que elas são relacionadas à eventual ocorrência do abuso do poder econômico nas eleições, fato este decorrente, dentre outros motivos, do financiamento irregular da atividade política.

$\mathrm{O}$ art. $1^{\circ}$, inciso I, alínea "d"392 traz a primeira hipótese de inelegibilidade por abuso do poder econômico, sendo consideradas inelegíveis as pessoas que cometerem ou se beneficiarem do cometimento de ato configurador de abuso do poder econômico. Eles ficam inelegíveis, se condenados, para a eleição a qual estão concorrendo e para todos os pleitos que ocorrerem nos três anos seguintes.

A segunda hipótese de decretação de inelegibilidade no caso de ocorrência de abuso do poder econômico é o previsto no art. $1^{\circ}$, inciso I, alínea " $h$ " da LI. Trata esta hipótese da eventual decretação de inelegibilidade de pessoas que no ato de abuso estejam ocupando cargos na Administração Pública.

Enquanto que a previsão da alínea "d" diz respeito a pessoas pertençam à Administração Pública como agentes políticos e aos que não fazem parte dela ${ }^{393}$, a proposição da alínea " $h$ " tem como objetivo punir os detentores de cargos ou empregos públicos, como por exemplo, um diretor de sociedade de economia mista que direciona recursos da empresa em um projeto, visando assim obter votos para si ou para um candidato de sua preferência ${ }^{394}$.

Ressalte-se que no caso da alínea "h" o agente infrator deve ter algum tipo de poder de mando político ou administrativo na hierarquia da Administração Pública. Não sendo o infrator portador de influência ou prestígio suficiente para exceder-se no poder,

392 “Art. $1^{\text {o }}$ São inelegíveis:

I - para qualquer cargo:

(...)

d) os que tenham contra sua pessoa representação julgada procedente pela Justiça Eleitoral, transitada em julgado, em processo de apuração de abuso do poder econômico ou político, para a eleição na qual concorrem ou tenham sido diplomados, bem como para as que se realizarem 3 (três) anos seguintes;

(...)

h) os detentores de cargo na administração pública direta, indireta ou fundacional, que beneficiarem a si ou a terceiros, pelo abuso do poder econômico ou político apurado em processo, com sentença transitada em julgado, para as eleições que se realizarem nos 3 (três) anos seguintes ao término do seu mandato ou do período de sua permanência no cargo".

${ }^{393}$ Cf. Joel J. Cândido, Inelegibilidades no direito brasileiro, p. 156.

${ }^{394}$ Cf. Adriano Soares da Costa, Instituições de direito eleitoral, p. 258-259. 
não há a incidência da norma. Nos dois casos, o cometimento do abuso deve ter finalidade eleitoral ou partidária, adequando-se assim no disposto no art. $14, \S 9^{\circ}$ da Constituição ${ }^{395}$.

Para um melhor exame das duas previsões de inelegibilidade que se referem ao abuso do poder econômico, deve-se entender mais profundamente qual é sua definição. Adriano Soares da Costa, por exemplo, afirma que há abuso do poder econômico quando o candidato dá algum tipo de vantagem a uma parte do eleitorado, vantagem essa de caráter determinável ou não, havendo ou não a possibilidade de beneficiar o eleitorado, com o objetivo de obter deles o voto. Assevera o autor, porém, que para a caracterização do abuso, deve haver a potencialidade do ato lesivo, ou seja, há a necessidade de que o fato jurídico irregular tenha possibilidade de influir no resultado da eleição. Portanto, deve haver nexo causal entre o resultado das urnas e o ato cometido $^{396}$.

Ressalte-se que a norma não pune o uso do poder econômico. Há a punição se houver abuso, ou seja, se o infrator usar do poder econômico em excesso com o intuito de amealhar mais votos, quebrando assim o princípio da igualdade, princípio esse que norteia todo o processo eleitoral e deve prevalecer na disputa entre os candidatos.

$\mathrm{O}$ texto das duas previsões de inelegibilidade em comento diz respeito à "representação julgada procedente pela Justiça Eleitoral". Cabe perguntar: de que representação refere-se o texto normativo?

O art. 96 da LE, por exemplo, prevê o trâmite da representação eleitoral. Pode-se entender também que o texto refere-se à ação de investigação judicial eleitoral (AIJE), prevista no art. 22 da LI. Além dessas duas possibilidades, poder-se-ia entender que a ação cabível neste caso é a prevista no art. 14, § 10 da Constituição, ou seja, a ação de impugnação de mandato eletivo.

\footnotetext{
${ }^{395}$ Cf. Joel J. Cândido, Inelegibilidades no direito brasileiro, p.203-205.

${ }^{396}$ Cf. Adriano Soares da Costa, Instituições de direito eleitoral, p. 531. Afirmam no mesmo sentido, ou seja, de que a irregularidade deve ter distorcido o resultado a ponto de afetar a normalidade e a legitimidade do pleito, a probidade administrativa, a moralidade para o exercício do mandato (art. 14, § $9^{\circ}$ da Constituição) Renato Ventura Ribeiro, Lei eleitoral comentada, p. 194 e Joel J. Cândido, Direito eleitoral brasileiro, p. 455
} 
O termo "representação" no texto em debate refere-se, na verdade, à petição inicial. Em observação ao disposto no art. 22 da LI, que remete ao rito processual da AIJE, há referência à representação, ação esta com o objetivo de se abrir investigação judicial para a apuração de abuso do poder econômico. Assim sendo, a ação cabível para a apuração de abuso do poder econômico nas hipóteses de inelegibilidade é a AIJE, conforme afirmação de Adriano Soares da Costa e Joel Cândido ${ }^{397}$, eis que esta pode acarretar ao candidato infrator a condenação de inelegibilidade, sendo cassado o seu registro de candidatura, se ainda não tiver sido diplomado; ou a cassação do diploma ( e a conseqüente perda do mandato, se já houver sido expedido).

A apresentação de AIME também é possível, já que o $§ 10$ do art. 14 da Constituição prevê a eventual ocorrência do abuso do poder econômico como um dos requisitos para a impugnação do mandato eletivo. Porém, a mesma disposição prevê que a AIME só poderá ser apresentada após a diplomação do suposto infrator (prazo máximo de 15 dias contados da diplomação) ${ }^{398}$.

Os outros dois requisitos para uma possível apresentação de uma AIME é a eventual ocorrência de fraude ou corrupção. $\mathrm{O}$ abuso do poder econômico consiste na conquista do voto de maneira que o eleitor não suspeite de que está sendo convencido por meio de artifícios. Essa conquista se dá por meio arguto, tênue; e o infrator se usa de meios legais para conquistar o convencimento do eleitor, mas esses meios legais são usados de maneira abusiva, gerando desequilíbrio, afronta ao princípio de igualdade de condições. Ao contrário, quando o voto é amealhado de maneira direta, amoral, como na compra do voto em troca de bem ou dinheiro, ocorre a hipótese constitucional da corrupção eleitoral $^{399}$. A fraude, de outra forma, consiste na eventual enganação do eleitor. O votante é iludido, ludibriado com o intuito de conseguir benefícios na seara eleitoral.

Dispõe o texto em análise que a condenação somente será aplicada se houver o trânsito em julgado da ação. Assim sendo, em respeito ao princípio da presunção da inocência (art. 5\%, inciso LVIII da Constituição), o representado, se eleito e já

\footnotetext{
${ }^{397}$ Cf. Joel J. Cândido, Inelegibilidades no direito brasileiro, p. 157.

${ }^{398}$ Cf. Adriano Soares da Costa, Instituições de direito eleitoral, p. 236.

${ }^{399}$ Cf. Joel J. Cândido, Inelegibilidades no direito brasileiro, p. 338-339.
} 
diplomado, exercerá o mandato até que a condenação judicial seja confirmada, não havendo mais nenhuma possibilidade de recurso.

Quanto ao prazo da punição, prevê as duas alíneas ora em debate a cassação do registro de candidatura ou do diploma, se este já tiver sido expedido, e mais três anos de condenação por inelegibilidade. Assim sendo, a primeira sanção refere-se ao pleito em que ocorreu o abuso. Se o trânsito em julgado ocorrer antes da diplomação, cassa-se o registro da candidatura do infrator. Se a impossibilidade de recurso contra a decisão condenatória ocorreu depois da diplomação, cassa-se o diploma.

Os três anos previstos nas alíneas "d" e "h" do inciso I do art. $1^{\circ}$ da LI contam-se da eleição em que houve o abuso do poder econômico. Assim, caso o candidato tenha cometido abuso na eleição de 2008, ele não poderá candidatar-se para as eleições que ocorrerem até três anos após. Ou seja, fica o infrator impedido de concorrer na própria eleição em que infringiu a norma (2008) e na de 2010. Na eleição seguinte, em 2012, já poderá concorrer, eis que o pleito ocorrerá quatro anos após o cometimento do abuso.

A alínea "h", no entanto, dispõe sobre a inelegibilidade durante o período de permanência no cargo. Criou-se essa hipótese, segundo Joel Cândido, para que fossem punidos também os infratores que detêm cargos sem mandato por tempo certo ${ }^{400}$. Assim, no caso em voga, o infrator estará inelegível enquanto permanecer no cargo e por mais três anos, contados a partir da data de sua saída do cargo.

Surge, no entanto, interessante questão, ante o prazo acima citado: se o infrator não deixar o cargo, há algum tipo de limite temporal para os efeitos dessa condenação de inelegibilidade? A resposta é não; não há qualquer limite temporal: o detentor do cargo poderá ser considerado inelegível até, por exemplo, sua aposentadoria ou sua demissão. Obviamente, após isto, contar-se-á mais três anos para o fím da pena, em claro desrespeito à vedação constitucional de aplicação de penas perpétuas ( $\operatorname{art.} 5^{\circ}$, inciso XLVII, alínea “b”).

${ }^{400}$ Cf. Joel J. Cândido, Inelegibilidades no direito brasileiro, p. 207. 
Joel Cândido sugere a adoção de delimitação do período de pena no caso em debate de um prazo de oito anos, por ser esse o maior prazo de inelegibilidade previsto na própria LI (art. $1^{\mathrm{o}}$, inciso I, alínea “b”) $)^{401}$.

Outra discussão pertinente às hipóteses de inelegibilidade por abuso do poder econômico refere-se ao fato de o inciso XIV do art. 22 da LI, que determina caso seja julgada procedente a AIJE, a declaração da inelegibilidade e de todos aqueles que contribuíram para o abuso para as eleições que ocorrerem nos três anos subseqüentes ao pleito maculado, além da cassação do registro do candidato beneficiado pelo cometimento do abuso.

Declarada a inelegibilidade, os autos processuais devem ser remetidos ao Ministério Público Eleitoral, para instauração de processo disciplinar ou processocrime, se for o caso.

O inciso citado deve ser aplicado ao infrator que não foi candidato; ao infrator que foi candidato, porém não obteve sucesso; e ao infrator candidato que foi eleito, desde que a AIJE tenha sido julgada em até 15 dias após a diplomação.

No caso de a AIJE não ter sido julgada após a diplomação (há permissão legal para tanto, eis que o art. $1^{\circ}$, I, “d”, por exemplo, contém a expressão “ou tenham sido diplomados", deve o interessado apresentar recurso contra a expedição de diploma (caso atenda os requisitos do recurso, previstos no art. 262, inciso IV do CE) ou aguardar até o $15^{\circ}$ dia após a diplomação para propor uma AIME, conforme expressa determinação do inciso XV do art. 22. Se não propuser nem o recurso contra a diplomação e nem a ação impugnando o mandato do infrator caso a AIJE não tenha ainda sido julgada, verá seu direito decair ${ }^{402}$. No mesmo sentido manifesta-se Olivar Augusto Roberti Coneglian, que ressalta o fato de o texto do inciso XV ser contrário ao espírito do resto da $\mathrm{LI}^{403}$.

\footnotetext{
${ }^{401}$ Cf. Joel J. Cândido, Inelegibilidades no direito brasileiro, p. 208.

${ }^{402} \mathrm{Cf}$. Joel J. Cândido, Inelegibilidades no direito brasileiro, p. 375.

${ }^{403}$ Cf. Olivar Augusto Roberti Coneglian, Inelegibilidade: inelegibilidade e proporcionalidade, inelegibilidade e abuso de poder , p. 169.
} 


\section{ANÁlISE DAS PRESTAÇÕES DE CONTAS DAS CAMPANHAS PRESIDENCIAIS DE 2002 E 2006}

\subsection{Parâmetros para a análise das prestações de contas presidenciais}

Neste capítulo serão feitas as análises das prestações de contas entregues à Justiça Eleitoral nas eleições de 2002 e 2006 de dois tipos de pleitos ocorridos: a eleição para a Presidência da República e a eleição para a Câmara dos Deputados no Estado de São Paulo.

Na eleição à Presidência, serão estudados quatro candidatos (de um total de seis) nas eleições de 2002 e mais quatro candidatos (de um total de oito candidatos) nas eleições de 2006.

Houve a exclusão de alguns dos candidatos por dois motivos: o primeiro é o fato de nenhum dos candidatos excluídos ter atingido ao menos $1 \%$ dos votos válidos nestas eleições. Este resultado eleitoral denota a falta de representatividade de suas candidaturas frente ao eleitorado, fato este comprovado pelo segundo motivo do corte dos mesmos desta análise: tanto em 2002 como em 2006, os candidatos que não conseguiram pelo menos $1 \%$ dos votos válidos pertenciam a partidos que da mesma forma são bastante fracos na contagem de votos: nenhuma das legendas desses candidatos conseguiu ao menos uma cadeira na Câmara dos Deputados ${ }^{404}$.

Em 2002, portanto, serão analisadas as prestações de contas de Luiz Inácio Lula da Silva (PT), José Serra (PSDB), Anthony Garotinho (PSB) e Ciro Gomes (PPS). Não serão examinadas as prestações de contas eleitorais dos candidatos Zé Maria (PSTU) e Rui Costa Pimenta (PCO), uma vez que não atingiram o patamar de $1 \%$ dos votos válidos, além de seus partidos não conseguirem sequer uma cadeira na Câmara dos Deputados.

\footnotetext{
${ }^{404}$ Nas eleições de 2002, havia 30 partidos registrados no TSE, e 19 deles conseguiram eleger ao menos um deputado federal. PCO e PSTU foram uma das 11 legendas que não atingiram o feito. Nas eleições de 2006, 21 partidos conseguiram eleger ao menos um deputado federal em todo o território nacional. O PRP, o PCO, o PSL e o PSDC, mesmo patrocinando candidaturas presidenciais, fato este que garante maior visibilidade no período eleitoral, principalmente no horário eleitoral gratuito, estiveram na relação de oito partidos que não elegeram sequer um de seus filiados nas eleições para a Câmara dos Deputados.
} 
Em 2006, da mesma forma, serão estudadas as prestações de contas de Luiz Inácio Lula da Silva (PT), Geraldo Alckmin (PSDB), Heloísa Helena (PSOL) e Cristovam Buarque (PDT). Ficam excluídas da análise neste trabalho as prestações de contas entregues à Justiça Eleitoral por Ana Maria Rangel (PRP), José Maria Eymael (PSDC), Luciano Bivar (PSL) e Rui Costa Pimenta (PCO), visto que suas respectivas votações foram menores que $1 \%$ dos votos válidos e seus partidos não conseguiram eleger nenhum deputado federal em todos Estados brasileiros e também no Distrito Federal.

A análise das prestações de contas dos candidatos à Presidência da República se divide em duas partes. A primeira delas tratará da arrecadação de recursos para as campanhas presidenciais e a segunda parte é relativa às despesas feitas pelos postulantes ao Palácio do Planalto. A análise da arrecadação de campanha será dividida em três partes: (i) origem das receitas; (ii) meio financeiro de doação; e (iii) período em que ocorreu a doação.

A primeira parte, que trata da origem das doações, servirá para comprovar se as campanhas eleitorais presidenciais são realmente dependentes das doações de pessoas jurídicas, conforme afirmam, por exemplo, David Samuels ${ }^{405}$, com as decorrências negativas já vistas no item 2.1.4.

O segundo elemento referente à arrecadação nas campanhas eleitorais presidenciais a ser checado trata-se do meio financeiro utilizado pelos doadores para que o recurso chegasse ao candidato.

Este item deve ser estudado porque há três meios para tanto: cheque (entregue diretamente ao responsável pelas finanças da campanha ou depositado em conta bancária; em dinheiro, a ser entregue diretamente ao responsável financeiro da campanha; ou em bens ou serviços estimáveis em dinheiro, que nessa pesquisa aparecerá como "estimado".

\footnotetext{
${ }^{405}$ Cf. David Samuels, "Financiamento de campanhas e eleições no Brasil: o que podemos aprender com o 'caixa um' e propostas de reforma", p. 367.
} 
Renato Ventura Ribeiro define a doação de bens ou serviços estimáveis em dinheiro "os serviços prestados por terceiros e não cobrados, como, por exemplo, serviços advocatícios" ${ }^{\text {406. }}$.

A análise dos meios financeiros usados pelos doadores para contribuírem para as campanhas eleitorais é importante pelo fato que tanto nas doações em dinheiro como nas doações em estimado, há uma maior dificuldade da Justiça Eleitoral em realizar a fiscalização.

No caso do dinheiro, apesar da obrigatoriedade de o responsável financeiro pela campanha fazer o depósito do dinheiro recebido na conta bancária da campanha, há a possibilidade de o tesoureiro, em conluio com o doador, declarar o recebimento de uma quantia menor, usando parte do dinheiro para montar uma contabilidade paralela.

Ao mesmo tempo, a doação em bens ou serviços estimados dificulta a fiscalização e posterior julgamento pela Justiça Eleitoral pelo fato de haver subjetividade no momento da aferição do valor a ser declarado na prestação de contas como doação, visto que o responsável financeiro pode subfaturar a doação com o intuito de diminuir o valor das doações recebidas, não chamando tanta a atenção da sociedade, da mídia e também do fiscalizador.

Para terminar a análise da arrecadação nas campanhas presidenciais, serão examinados os momentos em que acontecem as doações. A legislação determina que a arrecadação possa ser iniciada no momento em que o comitê financeiro for registrado na Justiça Eleitoral. Conforme entendimento de Renato Ventura Ribeiro, no exame do art. 23 da LE, o registro do comitê se dá após os seguintes passos: solicitação do registro da candidatura; solicitação de registro do comitê, inscrição no CNPJ; abertura de conta bancária específica para a campanha; e impressão e obtenção dos recibos eleitorais ${ }^{407}$.

Da mesma forma, a arrecadação deve terminar no dia em que ocorre a eleição. Após, permite-se a arrecadação somente para a quitação das obrigações já contraídas. A

\footnotetext{
${ }^{406}$ Renato Ventura Ribeiro, Lei eleitoral comentada, p. 182.

${ }^{407}$ Cf. Renato Ventura Ribeiro, Lei eleitoral comentada, p. 180.
} 
legislação determina como prazo máximo para a quitação de todas as obrigações o momento de entrega da prestação de contas à Justiça Eleitoral.

A segunda parte da análise das prestações de contas trata das despesas feitas nas campanhas eleitorais. Serão analisados os períodos em que as despesas são feitas, no intuito de perceber se as mesmas acompanham o ritmo da receita ou se elas são feitas independentemente da receita, diante da rápida necessidade da campanha em gastar recursos visando à vitória eleitoral.

Por fim, serão analisados os tipos de gastos eleitorais, para se possa entender melhor como são feitas as campanhas presidenciais brasileiras.

Antes de adentrar na análise em si, é necessário explicar os parâmetros usados nesta pesquisa para o melhor entendimento deste trabalho. Em referência à origem da arrecadação, houve a divisão em: pessoa física; pessoa jurídica, recursos não identificados ${ }^{408}$; recursos advindos da comercialização de bens ou da realização de eventos; e recursos com origem em outras candidaturas, em comitês financeiros ou do próprio partido.

Para a arrecadação de mais recursos, os candidatos podem realizar eventos, como jantares de campanha ou comercializar bens. Todo o valor arrecadado será revertido à campanha, devendo ser tudo declarado, além de haver emissão de recibos eleitorais para cada pessoa que contribuir nessa forma de doação.

Quanto às análises referentes aos períodos em que ocorreram receitas ou despesas, este trabalho fez a seguinte divisão: (i) período pré-eleitoral; (ii) primeiro mês eleitoral; (iii) segundo mês eleitoral; (iv) terceiro mês eleitoral; (v) segundo turno (se for o caso); e (vi) período eleitoral.

O período pré-eleitoral consiste em qualquer receita ou despesa feita antes de 30 de junho do ano eleitoral; já o primeiro mês eleitoral refere-se ao mês de julho ( $1^{\circ}$ a 31 )

\footnotetext{
${ }^{408}$ Os recursos não identificados consistem em recursos em que houve falha na identificação ou até nenhuma identificação. Os mesmos não podem ser usados na campanha eleitoral, devendo compor as chamadas sobras de campanhas, que serão repassadas aos partidos após o fim do período eleitoral.
} 
do ano eleitoral; o segundo mês eleitoral trata-se do mês de agosto do ano eleitoral $\left(1^{\circ}\right.$ a $31)$.

O terceiro mês eleitoral é na verdade um período maior que setembro do ano eleitoral: nesta pesquisa, ele equivale ao mês de setembro inteiro até o dia da ocorrência da eleição. A CRFB prevê, em seu art. 77 caput, que as eleições em primeiro turno aconteçam no primeiro domingo de outubro do ano eleitoral. Assim sendo, na eleição de 2002 a eleição ocorreu no dia 7; em 2006, no dia $1^{\circ}$ de outubro.

Não obstante, para as eleições de 2002, considera-se o terceiro mês eleitoral todo o mês de setembro de mais os seis primeiros dias de outubro. Já em 2006, o terceiro mês eleitoral consiste no mês inteiro de setembro mais o dia $1^{\circ}$ de outubro.

Para os candidatos derrotados já no primeiro turno, o período pós-eleitoral começa exatamente no dia seguinte ao da eleição. Assim sendo, para a eleição de 2002, o período pós-eleitoral se inicia em 7 de outubro; para a eleição de 2006, começa em 2 de outubro.

Aos postulantes presidenciais que passaram ao segundo turno, no entanto, nestas datas começa o período chamado "segundo turno", que dura até o dia da eleição no segundo turno, já que o art. 77, caput da CRFB dispõe que a eleição de segundo turno ocorra no último domingo de outubro. Em 2002, a segunda votação ocorreu em 27 de outubro; em 2006, em 29 de outubro. A partir daí - para os candidatos que foram ao segundo turno - inicia-se o período pós-eleitoral.

Nas prestações de contas disponíveis no sítio eletrônico do TSE, há um longo rol de tipos de gastos eleitorais. Neste trabalho, eles foram condensados em nove temas:

a) Encargos: despesas com taxas bancárias, impostos, taxas, contribuições previdenciárias e outros tributos;

b) Propaganda: toda e qualquer despesa que se relacione à divulgação da candidatura perante o eleitorado, como criação de sítios na Internet; impressos; publicidade por meio de faixas, placas, carros de som; produção de programas para rádio e/ou televisão;

c) Pessoal: despesa com remuneração de funcionários e alimentação; 
d) Serviços: despesas com honorários profissionais ou o item referente a serviços prestados por terceiros

e) Infra-estrutura: gastos com a formação de um comitê e os materiais necessários para seu funcionamento: água, energia elétrica, telefone, materiais de expediente, locação de bens móveis, bens permanentes, aluguéis

f) Diversas: são as despesas que, conforme ditame do art. $28, \S 2^{\circ}$, alínea "b" da Resolução TSE n. 20.987/02, não se adéquam a nenhum outro item;

g) Doações: são considerados gastos eleitorais a doação de uma candidatura para outra;

h) Transporte: despesas com combustível, lubrificantes, passagens e locação de bens móveis.

i) Baixa Recursos Estimáveis: segundo Felippe Lizardo, esses gastos consistem na doação de bens ou serviços em estimado para a própria campanha eleitoral. O doador doa o bem ou serviço de forma gratuita, sem que o candidato ou comitê realize qualquer transação financeira para o pagamento deste bem ou serviço. Ao fazer a inclusão desse bem ou serviço por meio do programa SPCE, o mesmo realiza "a baixa automática da receita na despesa correspondente, ou seja, para que possa haver o 'fechamento' das contas realiza-se a saída desta receita como uma despesa na prestação de contas”.

O analista do Tribunal Regional Eleitoral de São Paulo especialista em prestação de contas eleitorais explica que caso não houvesse a baixa, o programa apresentaria sobra de campanha, pois haveria receita sem a conseqüente despesa ${ }^{409}$.

Nas eleições de 2006, porém, não há a identificação do tipo de despesa realizada por meio desse mecanismo. Por exemplo, se a doação em bem ou serviço consistiu na cessão de um imóvel de propriedade de uma pessoa física para o funcionamento de um comitê, no momento da despesa aparecerá como tipo de gasto "recurso de pessoa física", e não "cessão de imóvel”, por exemplo. Assim, nessa pesquisa, foram reunidos em um só tipo de gasto todos os tipos de doação em valor estimado feita durante a campanha, seja de pessoa física, jurídica, partido, comitê ou candidato.

\footnotetext{
409 Entrevista feita com Felippe Lizardo, analista judiciário da Coordenadoria de Contas Partidárias e Eleitorais do Tribunal Regional Eleitoral de São Paulo em 8.1.10.
} 


\subsection{Eleição Presidencial de 2002}

As eleições de 2002 à Presidência da República contaram com seis candidatos: o ex-deputado federal e candidato à Presidência nas eleições de 1989, 1994 e 1998 Luiz Inácio Lula da Silva (PT/PL/PC do B/PCB/PMN), o ex-deputado federal, ex-ministro do Planejamento e da Saúde e então senador José Serra (PSDB/PMDB), o exgovernador Anthony Garotinho (PSB/PGT/PTC), o ex-governador e ex-ministro da Fazenda Ciro Gomes (PPS/PTB/PDT), José Maria de Almeida (PSTU) e Rui Costa Pimenta (PCO).

Muitos partidos não apresentaram candidatos e também não participaram de nenhuma coligação em virtude da decisão exarada pelo TSE e confirmada pelo STF que criou o princípio da coerência político-eleitoral, conhecida popularmente como "verticalização" das coligações.

Esse princípio, conforme já visto no Capítulo 2 deste trabalho, consiste na proibição de um partido participante de uma coligação na eleição presidencial formar uma aliança em um ou mais Estados com uma legenda participante de outra coligação para o pleito presidencial. Exemplificando: havendo uma coligação na eleição ao Palácio do Planalto formada pelos partidos ABC e DEF; e outra com os partidos GHI e MNO, os partidos ABC e DEF não poderiam coligar-se em nenhuma eleição estadual (ou distrital) aos partidos GHI e MNO.

Não havia, porém, a obrigatoriedade da manutenção da coligação nacional nos Estados; portanto, os partidos $\mathrm{ABC}$ e DEF poderiam lanças candidaturas ao governo estadual separadamente, mas jamais se coligarem com GHI ou MNO. Os partidos que não fizessem parte de nenhuma coligação na eleição presidencial estavam livres para formar alianças nos estados com qualquer partido, participante ou não da eleição presidencial.

O eleição ocorreu em 6 de outubro de 2002, mas nenhum candidato atingiu a maioria absoluta dos votos válidos, conforme se vê na tabela a seguir: 
Tabela 1- Resultado $1^{\circ}$ Turno Eleição Presidencial (6.10.2002) $)^{410}$

\begin{tabular}{|l|l|r|c|}
\hline \multicolumn{1}{|c|}{ Candidato } & Partido & Votos Nominais & Votos Válidos \\
\hline LUIZ INÁCIO LULA DA SILVA & PT & 39.455 .233 & $46,45 \%$ \\
\hline JOSÉ SERRA & PSDB & 19.705 .445 & $23,20 \%$ \\
\hline ANTHONY GAROTINHO & PSB & 15.180 .097 & $17,87 \%$ \\
\hline CIRO GOMES & PPS & 10.170 .882 & $11,97 \%$ \\
\hline JOSÉ MARIA DE ALMEIDA & PSTU & 402.236 & $0,47 \%$ \\
\hline RUI COSTA PIMENTA & PCO & 38.619 & $0,04 \%$ \\
\hline
\end{tabular}

Foram para o segundo turno, portanto, Lula e José Serra. Na eleição realizada em 27 de outubro de 2002, o resultado foi a vitória de Lula, conforme a tabela a seguir:

Tabela 29 - Resultado $2^{\circ}$ Turno Eleição Presidencial $(27.10 .2002)^{411}$

\begin{tabular}{|l|l|r|r|}
\hline \multicolumn{1}{|c|}{ Candidato } & Partido & Votos Nominais & \multicolumn{1}{c|}{ Votos Válidos } \\
\hline LUIZ INÁCIO LULA DA SILVA & PT & 52.793 .364 & $61,27 \%$ \\
\hline JOSÉ SERRA & PSDB & 33.370 .739 & $38,73 \%$ \\
\hline
\end{tabular}

Nas eleições de 2002, os candidatos José Serra, Anthony Garotinho e Ciro Gomes apresentam suas contas eleitorais por meio de seus respectivos comitês, não havendo prestação de contas em separado em nome do candidato. Já o candidato e vencedor da eleição Luiz Inácio Lula da Silva apresentou duas prestações de contas: a de seu comitê e outra em nome de sua candidatura. Neste trabalho, será analisada a prestação de contas em nome de sua candidatura.

A arrecadação de recursos, os gastos eleitorais e as prestações de contas nas campanhas eleitorais foram disciplinados pela Lei das Eleições (artigos 17 a 32 e 81) e pela Resolução TSE n. 20.987/02. Os artigos referentes à Lei das Eleições já foram analisados em profundidade no Capítulo 3 deste trabalho. No que couber, serão feitas reminiscências aos dispositivos legais, além de ser citados da mesma forma os ditames relevantes da referida Resolução exarada pelo TSE.

\footnotetext{
${ }^{410}$ Resultado disponível em <www.tse.jus.br>. Último acesso em 15.11.2009.

${ }^{411}$ Resultado disponível em <www.tse.jus.br>. Último acesso em 15.11.2009.
} 
Conforme visto no item 5.1, no que toca à arrecadação, haverá três tipos de análise: a origem das receitas; o meio financeiro utilizado; e o período em que ocorreram as doações.

Quanto à origem das receitas, o art. 10 da Resolução TSE n. 20.987/02 determina que as possíveis origens das doações às campanhas eleitorais são: (i) recursos próprios; (ii) doações de pessoas físicas; (iii) doações de pessoas jurídicas; (iv) doações de outros candidatos, comitês financeiros ou partidos; (v) repasse de recursos provenientes do Fundo Partidário; (v) receita decorrente da comercialização de bens ou serviços. Ressalte-se que se um recurso arrecadado não tiver a respectiva arrecadação, é vedado seu uso na campanha, devendo o valor compor as sobras de campanha e ser repassado à direção partidária (art. 17 da Resolução TSE n. 20.987/02).

Neste quesito, a arrecadação dos candidatos à Presidência em 2002 deu-se da seguinte forma, entre os candidatos que não foram ao segundo turno da eleição:

Tabela 30 - Origem da Arrecadação (Ciro Gomes e Anthony Garotinho)

\begin{tabular}{|l|r|r|r|r|}
\hline & \multicolumn{2}{|c|}{ Ciro Gomes } & \multicolumn{2}{c|}{ Garotinho } \\
\hline Pessoa Física & $\mathrm{R} \$ 570.260,00$ & $4,1 \%$ & $\mathrm{R} \$ 42.557,00$ & $1,3 \%$ \\
\hline Pessoa Jurídica & $\mathrm{R} \$ 13.367 .605,72$ & $95,9 \%$ & $\mathrm{R} \$ 3.186 .520,00$ & $97,2 \%$ \\
\hline Partido ou Comitê & $\mathrm{R} \$ 0,00$ & $0,0 \%$ & $\mathrm{R} \$ 50.000,00$ & $1,5 \%$ \\
\hline Não Identificados & $\mathrm{R} \$ 210,43$ & $0,0 \%$ & $\mathrm{R} \$ 0,00$ & $0,0 \%$ \\
\hline $\begin{array}{l}\text { Comercialização / } \\
\text { Eventos }\end{array}$ & $\mathrm{R} \$ 4.800,00$ & $0,0 \%$ & $\mathrm{R} \$ 0,00$ & $0,0 \%$ \\
\hline TOTAL & $\mathrm{R} \$ 13.942 .876,15$ & $100,0 \%$ & $\mathrm{R} \$ 3.279 .077,00$ & $100,0 \%$ \\
\hline
\end{tabular}

Vê-se claramente que no caso dos dois candidatos derrotados no primeiro turno, a absoluta predominância dos recursos com origem em pessoas jurídicas. Foram as pessoas jurídicas as responsáveis por 95,9\% e 97,2\% da arrecadação das campanhas de Ciro Gomes e Anthony Garotinho, respectivamente, havendo em conseqüência pequena participação das pessoas físicas no financiamento da campanha eleitoral de ambos.

Ciro Gomes não recebeu nenhuma quantia dos três partidos pertencentes à sua coligação; já Garotinho recebeu apenas R\$ 50.000,00 de seu partido, valore que representou $1,5 \%$ de sua arrecadação total. Ciro Gomes amealhou insignificante 
montante referente à comercialização de bens, além de recursos não identificados, visto que somados não chegam sequer a $0,1 \%$.

Da mesma forma, os candidatos que competiram no segundo turno - José Serra e Luiz Inácio Lula da Silva - também tiveram suas campanhas majoritariamente financiadas por pessoas jurídicas, conforme se depreende da tabela abaixo:

Tabela 431 - Origem da Arrecadação (José Serra e Luiz Inácio Lula da Silva)

\begin{tabular}{|l|r|r|r|r|}
\hline & \multicolumn{2}{|c|}{ Serra } & \multicolumn{2}{c|}{ Lula } \\
\hline Pessoa Física & $\mathrm{R} \$ 1.459 .175,00$ & $5,1 \%$ & $\mathrm{R} \$ 221.428,02$ & $1,1 \%$ \\
\hline Pessoa Jurídica & $\mathrm{R} \$ 27.036 .486,80$ & $94,7 \%$ & $\mathrm{R} \$ 13.433 .078,16$ & $63,7 \%$ \\
\hline Partido ou Comitê & $\mathrm{R} \$ 44.600,00$ & $0,2 \%$ & $\mathrm{R} \$ 7.402 .183,80$ & $35,1 \%$ \\
\hline Não Identificados & $\mathrm{R} \$ 0,00$ & $0,0 \%$ & $\mathrm{R} \$ 11.129,00$ & $0,1 \%$ \\
\hline $\begin{array}{l}\text { Comercialização / } \\
\text { Eventos }\end{array}$ & $\mathrm{R} \$ 0,00$ & $0,0 \%$ & $\mathrm{R} \$ 4.657,00$ & $0,0 \%$ \\
\hline TOTAL & $\mathrm{R} \$ 28.540 .261,80$ & $100,0 \%$ & $\mathrm{R} \$ 21.072 .475,98$ & $100,0 \%$ \\
\hline
\end{tabular}

A arrecadação de José Serra se aproximou bastante das de Ciro Gomes e Anthony Garotinho, já que as pessoas jurídicas foram responsáveis por 94,7\% do dinheiro para o financiamento de sua campanha. Seu partido doou apenas $0,2 \%$ do valor total arrecadado, enquanto as pessoas físicas doaram $5,1 \%$.

$\mathrm{Na}$ prestação de contas de Luiz Inácio Lula da Silva permanece a forte predominância das doações proeminentes das pessoas jurídicas, responsáveis por $63,7 \%$ do valor arrecadado em sua vitoriosa campanha. No entanto, houve uma porcentagem de $35,1 \%$ de doações com origem em partidos, comitês financeiros de campanha ou de outros candidatos.

Conforme já visto anteriormente, empresas doam recursos ao partido na tentativa de esconder essa operação financeira por alguns meses, já que o partido prestará suas contas à Justiça Eleitoral somente em abril do ano seguinte.

Outros doadores preferem contribuir para as campanhas eleitorais de sua preferência fazendo donativos pelos comitês financeiros porque procuram não vincular seus nomes e as quantias doadas a um determinado candidato, uma vez que recebida a 
doação, o comitê - mesmo que seja específico para uma candidatura - pode repassar parcial ou integralmente esse valor para vários candidatos, impedindo que o eleitor e/ou a mídia saiba para quem exatamente dirigiu-se a doação.

Assim, mesmo que todas as doações feitas pelos partidos ou comitês à candidatura de Luiz Inácio Lula da Silva nas eleições de 2002 tenham sido feitas por pessoas físicas, percebe-se que, da mesma forma que nas prestações de contas de seus adversários, há uma clara predominância das doações originárias das pessoas jurídicas.

Quanto ao meio financeiro utilizado pelos doadores para a realização da contribuição ao candidato presidencial de sua preferência, houve notável diferença entre as candidaturas derrotadas no primeiro turno, conforme tabela a seguir:

Tabela 532 - Meio de Doação (Ciro Gomes e Anthony Garotinho)

\begin{tabular}{|l|r|r|r|r|}
\hline & \multicolumn{2}{|c|}{ Ciro Gomes } & \multicolumn{2}{c|}{ Garotinho } \\
\hline Cheque & $\mathrm{R} \$ 8.035 .250,00$ & $57,6 \%$ & $\mathrm{R} \$ 3.170 .060,00$ & $96,7 \%$ \\
\hline Dinheiro & $\mathrm{R} \$ 2.410 .020,43$ & $17,3 \%$ & $\mathrm{R} \$ 109.017,00$ & $3,3 \%$ \\
\hline Estimado & $\mathrm{R} \$ 3.497 .605,72$ & $25,1 \%$ & $\mathrm{R} \$ 0,00$ & \\
\hline TOTAL & $\mathrm{R} \$ 13.942 .876,15$ & $100,0 \%$ & $\mathrm{R} \$ 3.279 .077,00$ & $100,0 \%$ \\
\hline
\end{tabular}

Na campanha de Anthony Garotinho houve o predomínio absoluto das doações por cheque $(96,7 \%)$. As doações em dinheiro somaram apenas 3,3\%, não havendo nenhuma doação em bem ou serviço estimável em dinheiro.

Já a candidatura Ciro Gomes também arrecadou a maioria dos valores doados por meio de cheque $(57,6 \%)$. No entanto, houve grande parte das doações em dinheiro em espécie $(17,3 \%)$ e também em bens ou serviços estimáveis em dinheiro $(25,1 \%)$. Nas campanhas lideradas por José Serra e Luiz Inácio Lula da Silva, a situação não foi muito diferente, conforme tabela abaixo: 
Tabela 6 - Meio de doação (José Serra e Luiz Inácio Lula da Silva)

\begin{tabular}{|l|r|r|r|r|}
\hline & \multicolumn{2}{|c|}{ Serra } & \multicolumn{2}{c|}{ Lula } \\
\hline Cheque & $\mathrm{R} \$ 18.508 .335,01$ & $64,8 \%$ & $\mathrm{R} \$ 11.447 .450,00$ & $54,3 \%$ \\
\hline Dinheiro & $\mathrm{R} \$ 6.988 .150,00$ & $24,5 \%$ & $\mathrm{R} \$ 7.786 .428,21$ & $37,0 \%$ \\
\hline Estimado & $\mathrm{R} \$ 3.043 .776,79$ & $10,7 \%$ & $\mathrm{R} \$ 1.838 .597,77$ & $8,7 \%$ \\
\hline TOTAL & $\mathrm{R} \$ 28.540 .261,80$ & $100,0 \%$ & $\mathrm{R} \$ 21.072 .475,98$ & $100,0 \%$ \\
\hline
\end{tabular}

Em ambas as campanhas que foram ao segundo turno, a maioria das doações foi realizada por meio de cheque (Serra $-64,8 \%$; Lula $-54,3 \%$ ). Lula obteve $37 \%$ de suas doações em dinheiro em espécie, enquanto Serra obteve $24,5 \%$ dos recursos de campanha nesta modalidade. As doações em bens ou serviços estimáveis em dinheiro representaram a Serra e Lula, respectivamente, $10,7 \%$ e $8,7 \%$.

Esse quadro é preocupante, visto que das quatro principais candidaturas presidenciais em 2002, três delas usaram substancialmente das doações em dinheiro em espécie e das contribuições em bens e serviços estimáveis em dinheiros. Esses dois meios de doação, conforme já visto no item 5.1, representa a possibilidade de haver irregularidades nas campanhas eleitorais, uma vez que sua fiscalização é mais difícil.

No caso de doações em bens ou serviços estimados, para verificar a regularidade da doação, deve-se fazer uma pesquisa de mercado no intuito de descobrir se o valor doado realmente corresponde à realidade fática. Já a doação em dinheiro traz a possibilidade de haver a contabilidade em paralelo, com gastos eleitorais fora da prestação de contas, além de impossibilidade de se saber se o valor efetivamente doado é o mesmo que consta na prestação apresentada à Justiça Eleitoral.

O terceiro item a ser analisado no que se refere à arrecadação nas eleições presidenciais de $2002 \mathrm{diz}$ respeito ao momento em que o valor foi doado. Nas campanhas derrotadas no primeiro turno, a arrecadação de Anthony Garotinho disparou no terceiro mês do período eleitoral, se comparada com os dois primeiros meses.

Já Ciro Gomes também teve crescimento no terceiro mês, cujo último dia, para efeitos desta pesquisa, é o dia da eleição. Porém, boa parte do valor arrecadado na campanha já havia sido amealhado nos dois primeiros meses, conforme se vê na tabela adiante: 
Tabela 733 - Período de Arrecadação (Ciro Gomes e Anthony Garotinho)

\begin{tabular}{|l|r|r|r|r|}
\hline & \multicolumn{2}{|c|}{ Ciro Gomes } & \multicolumn{2}{c|}{ Garotinho } \\
\hline Período Pré-Eleitoral & $\mathrm{R} \$ 0,00$ & $0,0 \%$ & $\mathrm{R} \$ 0,00$ & $0,0 \%$ \\
\hline $\mathbf{1}^{\mathbf{0}}$ Mês Eleitoral & $\mathrm{R} \$ 821.300,00$ & $5,9 \%$ & $\mathrm{R} \$ 0,00$ & $0,0 \%$ \\
\hline $\mathbf{2}^{\mathbf{o}}$ Mês Eleitoral & $\mathrm{R} \$ 4.794 .372,74$ & $34,4 \%$ & $\mathrm{R} \$ 51.064,00$ & $1,6 \%$ \\
\hline $\mathbf{3}^{\mathbf{o}}$ Mês Eleitoral & $\mathrm{R} \$ 6.625 .384,98$ & $47,5 \%$ & $\mathrm{R} \$ 2.538 .013,00$ & $77,4 \%$ \\
\hline Período Pós-Eleitoral & $\mathrm{R} \$ 1.701 .818,43$ & $12,2 \%$ & $\mathrm{R} \$ 690.000,00$ & $21,0 \%$ \\
\hline TOTAL & $\mathrm{R} \$ 13.942 .876,15$ & $100,0 \%$ & $\mathrm{R} \$ 3.279 .077,00$ & $100,0 \%$ \\
\hline
\end{tabular}

Os dois candidatos tiveram a maior quantia de sua arrecadação para suas campanhas eleitorais doadas no terceiro período eleitoral (de $1^{\circ}$ de setembro a 6 de outubro, dia da eleição). No entanto, apenas 1,6\% das doações à candidatura Garotinho foram feitas em agosto de 2002 (não houve uma doação sequer em julho), enquanto $77,4 \%$ do valor arrecadado foi doado no $3^{\circ}$ período eleitoral (Ciro teve "apenas" 47,5\% no mesmo período).

Há duas explicações possíveis para esse crescimento da arrecadação de Garotinho após 1.9.2002: (i) a arrecadação nos dois primeiros meses eleitorais (julho e agosto) foi tão baixa que forçou o candidato e/ou seus assessores a intensificar a procura por recursos, sob pena de fracasso nas eleições (até 31.8.2002, a candidatura de Garotinho arrecadou apenas $\mathrm{R} \$ 51.064,00$ ); ou (ii) as pesquisas de intenção de voto eventualmente mostraram um crescimento da candidatura de Garotinho, motivando os potenciais financiadores a contribuírem com a campanha.

A tabela a seguir, que contém as pesquisas de intenção de voto para as eleições presidenciais de 2002 feitas pelo Instituto Datafolha, pode esclarecer a questão:

Tabela 8 - Pesquisas de Intenção de Voto $1^{\circ}$ Turno (Datafolha)

\begin{tabular}{|l|c|c|c|c|c|c|c|c|c|c|}
\hline & $\mathbf{7 / 6}$ & 4 e 5/7 & $\mathbf{3 0 / 7}$ & $\mathbf{1 5}$ e 16/8 & $\mathbf{3 0 / 8}$ & $\mathbf{9 / 9}$ & $\mathbf{1 9}$ e 20/9 & $\mathbf{2 6}$ e 27/9 & $\mathbf{2 / 1 0}$ & 4 e 5/10 \\
\hline Lula & 40 & 38 & 33 & 37 & 37 & 40 & 44 & 45 & 45 & 45 \\
\hline Serra & 21 & 20 & 16 & 13 & 19 & 21 & 19 & 19 & 21 & 19 \\
\hline Garotinho & 16 & 13 & 11 & 12 & 10 & 14 & 15 & 15 & 15 & 17 \\
\hline Ciro & 11 & 18 & 28 & 27 & 20 & 15 & 13 & 11 & 10 & 11 \\
\hline
\end{tabular}


Depreende-se que Anthony Garotinho, desde a primeira pesquisa feita no início do período eleitoral definido pela legislação (os dados foram coletados em 4 e em 5 de julho de 2002), estava em quarto lugar na intenção de votos do eleitorado brasileiro, tendo seu menor índice nas pesquisas justamente em 30 de agosto.

A próxima pesquisa, realizada em 9 de setembro, mostrou forte reação de Garotinho, que ainda estava em quarto lugar, mas empatado com Ciro Gomes pela margem de erro (que era de 2\%). Na pesquisa seguinte, feita pelo Datafolha em 19 e 20 de setembro, Garotinho ultrapassou Ciro Gomes, aumentando a diferença para o candidato do PPS em cada nova pesquisa. Com a consolidação de Garotinho em terceiro lugar, é possível que potenciais doadores tenham se interessado a contribuir com sua campanha, principalmente pela chance de ainda ultrapassar Serra e chegar ao segundo turno contra Luiz Inácio Lula da Silva. Essa possibilidade foi vislumbrada na última pesquisa, realizada na antevéspera e na véspera do dia da eleição, em que as intenções de voto em Garotinho encostaram-se ao índice apresentado por José Serra, havendo inclusive empate técnico graças a margem de erro de dois pontos percentuais (Garotinho 19 x Serra 21).

Ao mesmo tempo, a queda no ritmo da arrecadação da campanha de Ciro Gomes também pode ser explicada pelos resultados das pesquisas eleitorais. $\mathrm{O}$ candidato do PPS estava em quarto lugar na última pesquisa realizada antes do início do período eleitoral. Já em julho Ciro alcança o terceiro lugar, ultrapassando Garotinho. Na pesquisa realizada em 30 de julho, Ciro não só ultrapassa Serra, mas encosta no índice de Lula (Ciro 28 x Lula 33).

Essa pesquisa poderia sinalizar que o primeiro turno estava praticamente definido, e diante da pequena diferença, Ciro poderia vencer Lula, que sempre esteve bem à frente nas pesquisas realizadas até então. A pesquisa realizada no meio do segundo mês eleitoral (15 e 16 de agosto) demonstra estabilização no índice de Ciro, enquanto Lula novamente cresceu, permanecendo mais uma vez próximo aos $40 \%$ nas intenções de voto. 
Serra havia caído mais um pouco, porém agora em empate técnico com Garotinho e 14 pontos percentuais de distância de Ciro Gomes, cenário este que confirmava a pesquisa anterior, com Ciro e Lula indo ao segundo turno.

Essas duas pesquisas podem ter motivado os potenciais doadores a investirem pesado na campanha de Ciro Gomes. Contando-se apenas os dois primeiros meses do período eleitoral, Ciro Gomes foi o segundo candidato que mais arrecadou, ultrapassando inclusive Lula, líder em todas as pesquisas até então.

$\mathrm{Na}$ última pesquisa de agosto, porém, as intenções de voto em Ciro Gomes sofreram brusca queda. Com o crescimento do índice do candidato do PSDB, José Serra, os dois estavam em situação de empate técnico (Serra 19 x Ciro 20), enquanto Lula consolidou sua liderança, com 40 pontos. A partir de então, percebeu-se uma queda constante do índice de Ciro Gomes (chegou a $11 \%$ na última pesquisa de opinião), fato este que pode ter arrefecido seus doadores - as doações cresceram no período, mas não no mesmo ritmo de Garotinho e Lula.

Serra, ao contrário dos outros três candidatos, teve queda na arrecadação no terceiro mês eleitoral. Porém, os valores amealhados pela candidatura do PSDB eram tão maiores, conforme se depreenderá na tabela seguinte, que não é possível fazer qualquer relação entre sua arrecadação de campanha e os resultados indicados pelo Instituto Datafolha:

Tabela 9 - Período de Arrecadação (José Serra e Luiz Inácio Lula da Silva)

\begin{tabular}{|l|r|r|r|r|}
\hline & \multicolumn{2}{|c|}{ Serra } & \multicolumn{2}{c|}{ Lula } \\
\hline Período Pré-Eleitoral & $\mathrm{R} \$ 0,00$ & $0,0 \%$ & $\mathrm{R} \$ 0,00$ & $0,0 \%$ \\
\hline $\mathbf{1}^{\mathbf{0}}$ Mês Eleitoral & $\mathrm{R} \$ 12.000,00$ & $0,0 \%$ & $\mathrm{R} \$ 500.000,00$ & $2,4 \%$ \\
\hline $\mathbf{2}^{\mathbf{o}}$ Mês Eleitoral & $\mathrm{R} \$ 10.449 .165,53$ & $36,6 \%$ & $\mathrm{R} \$ 3.153 .577,62$ & $15,0 \%$ \\
\hline $\mathbf{3}^{\mathbf{0}}$ Mês Eleitoral & $\mathrm{R} \$ 10.318 .853,11$ & $36,2 \%$ & $\mathrm{R} \$ 5.628 .160,20$ & $26,7 \%$ \\
\hline Segundo Turno & $\mathrm{R} \$ 6.742 .043,16$ & $23,6 \%$ & $\mathrm{R} \$ 6.296 .597,22$ & $29,9 \%$ \\
\hline Período Pós-Eleitoral & $\mathrm{R} \$ 1.018 .200,00$ & $3,6 \%$ & $\mathrm{R} \$ 5.494 .140,94$ & $26,1 \%$ \\
\hline TOTAL & $\mathrm{R} \$ 28.540 .261,80$ & $100,0 \%$ & $\mathrm{R} \$ 21.072 .475,98$ & $100,0 \%$ \\
\hline
\end{tabular}

José Serra, conforme já debatido, teve forte queda no final do primeiro período eleitoral. Em meados de agosto, teve inclusive o terceiro lugar ameaçado, iniciando sua 
recuperação somente no final do segundo período (quando empatou tecnicamente com Ciro Gomes). Após, já em setembro, distanciou-se de Ciro e assumiu o segundo lugar, mas no final do período eleitoral viu-se ameaçado por Garotinho, consolidando sua segunda posição somente no dia da eleição, em 6 de outubro.

A arrecadação do candidato tucano começou na verdade também em agosto (em julho, coletou apenas R\$ 12.000,00). A quantia angariada no segundo mês eleitoral, porém, foi muito mais alta que as dos demais candidatos, sendo mais que o dobro da quantia amealhada por Ciro e quase três vezes maior que a do candidato petista.

Esse valor pode também explicar a forte e rápida reação nas pesquisas de intenção de voto de José Serra. Em pouco mais de um mês, saiu de uma situação de terceiro lugar (e em empate técnico com o quarto colocado, ressalte-se) para um segundo posto na intenção de votos, sem jamais ser novamente ultrapassado. Para tanto, arrecadou enorme quantia também no terceiro período eleitoral (entre $1^{\circ}$ de setembro e 6 de outubro, Serra novamente arrecadou mais de R \$ 10,3 milhões de reais), enquanto Ciro angariou pouco mais de $\mathrm{R}$ \$ 6,6 milhões e Lula $\mathrm{R} \$$ 5,6 milhões.

Garantido no segundo turno, Serra continuou a arrecadar mais que Lula. Entre 7 e 27 de outubro, o candidato tucano coletou $\mathrm{R} \$ 6,7$ milhões, enquanto que o postulante petista angariou quase R \$ 6,3 milhões. As pesquisas de intenção de votos, nesse caso, também não explicam os valores arrecadados, visto que no segundo turno, Serra jamais ameaçou a provável e concretizada vitória de Lula, conforme se vê na tabela a seguir:

Tabela 10 - Pesquisas de Intenção de Voto $2^{\circ}$ Turno (Datafolha)

\begin{tabular}{|l|c|c|c|c|}
\hline & $\mathbf{1 1 / 1 0}$ & $\mathbf{1 8 / 1 0}$ & $\mathbf{2 3 / 1 0}$ & $\mathbf{2 6 / 1 0}$ \\
\hline Luiz Inácio Lula da Silva & 58 & 61 & 59 & 58 \\
\hline José Serra & 32 & 32 & 31 & 32 \\
\hline
\end{tabular}

Tanto a reação de Serra no mês de agosto como sua consolidação no segundo posto no terceiro período eleitoral, consolidação esta que o levou ao segundo turno, não pode ser explicada pelo ritmo de arrecadação de recursos para sua campanha. Todavia, há outro dado que esclareça os motivos da reação de Serra e também sua consolidação 
no segundo posto, garantindo a possibilidade de vencer a eleição no segundo turno: o ritmo de suas despesas eleitorais e também a de seus adversários.

Tanto Ciro Gomes como Garotinho, os dois candidatos que em momentos diferentes ameaçaram o posto de José Serra no segundo turno, gastaram a maior parte de seus recursos no terceiro período eleitoral, conforme tabela a seguir:

Tabela 11 - Período de Gastos Eleitorais (Ciro Gomes e Anthony Garotinho)

\begin{tabular}{|l|rr|r|r|r|}
\hline & \multicolumn{3}{|c|}{ Ciro Gomes } & \multicolumn{2}{c|}{ Garotinho } \\
\hline Período Pré-Eleitoral & $\mathrm{R} \$$ & $502.232,79$ & $3,6 \%$ & $\mathrm{R} \$ 0,00$ & $0,0 \%$ \\
\hline $\mathbf{1}^{\mathbf{0}}$ Mês Eleitoral & $\mathrm{R} \$$ & $824.526,39$ & $5,9 \%$ & $\mathrm{R} \$ 0,00$ & $0,0 \%$ \\
\hline $\mathbf{2}^{\mathbf{o}}$ Mês Eleitoral & $\mathrm{R} \$ 3.178 .582,80$ & $22,8 \%$ & $\mathrm{R} \$ 41.360,70$ & $1,3 \%$ \\
\hline $\mathbf{3}^{\mathbf{o}}$ Mês Eleitoral & $\mathrm{R} \$ 8.624 .426,01$ & $61,9 \%$ & $\mathrm{R} \$ 1.983 .756,85$ & $61,8 \%$ \\
\hline Período Pós -Eleitoral & $\mathrm{R} \$$ & $808.276,50$ & $5,8 \%$ & $\mathrm{R} \$ 1.186 .316,35$ & $36,9 \%$ \\
\hline TOTAL & $\mathrm{R} \$ 13.938 .044,49$ & $100,0 \%$ & $\mathrm{R} \$ 3.211 .433,90$ & $100,0 \%$ \\
\hline
\end{tabular}

Os dois candidatos derrotados no primeiro turno tiveram índices praticamente idênticos de gastos eleitorais: ambos gastaram quase $62 \%$ do que arrecadaram entre $1^{\circ}$ de setembro e 6 de outubro, na tentativa de ultrapassar Serra e conseguirem chegar ao segundo turno contra Lula. Somados os períodos anteriores, Ciro gastou 94,2\% de seus recursos até o dia da eleição (somente 5,8\% foi gasto depois da eleição, em obrigações já fechadas, porém ainda não cumpridas). Garotinho, ao contrário, assumiu muito mais obrigações sem o imediato pagamento, já que 36,9\% de seus gastos foram feitos depois de 6 de outubro (ou seja, realizou o gasto antes da eleição, mas só pagou por ele após 6.10.02).

Parece bastante natural que quanto mais perto a eleição, mas se gaste na tentativa de vencê-la ou de ao menos garantir seu lugar no segundo turno. Esse fato se confirma com os dados obtidos na prestação de contas de José Serra. Quanto à prestação de contas de Lula, há índices diferentes, conforme a tabela adiante: 
Tabela 12 - Período de Gastos Eleitorais (José Serra e Luiz Inácio Lula da Silva)

\begin{tabular}{|l|r|r|r|r|}
\hline & \multicolumn{2}{|c|}{ Serra } & \multicolumn{2}{c|}{ Lula } \\
\hline Período Pré-Eleitoral & $\mathrm{R} \$ 347,69$ & $0,0 \%$ & $\mathrm{R} \$ 64.464,05$ & $0,3 \%$ \\
\hline $\mathbf{1}^{\mathbf{0}}$ Mês Eleitoral & $\mathrm{R} \$ 1.523 .781,25$ & $4,4 \%$ & $\mathrm{R} \$ 363.132,37$ & $1,7 \%$ \\
\hline $\mathbf{2}^{\mathbf{0}}$ Mês Eleitoral & $\mathrm{R} \$ 14.022 .799,14$ & $40,4 \%$ & $\mathrm{R} \$ 2.488 .358,72$ & $11,8 \%$ \\
\hline $\mathbf{3}^{\mathbf{o}}$ Mês Eleitoral & $\mathrm{R} \$ 11.973 .911,02$ & $34,5 \%$ & $\mathrm{R} \$ 5.795 .848,62$ & $27,5 \%$ \\
\hline Segundo Turno & $\mathrm{R} \$ 5.554 .167,09$ & $16,0 \%$ & $\mathrm{R} \$ 11.496 .622,34$ & $54,6 \%$ \\
\hline Período Pós -Eleitoral & $\mathrm{R} \$ 1.641 .529,83$ & $4,7 \%$ & $\mathrm{R} \$ 852.846,47$ & $4,0 \%$ \\
\hline TOTAL & $\mathrm{R} \$ 34.716 .536,02$ & $100,0 \%$ & $\mathrm{R} \$ 21.061 .272,57$ & $100,0 \%$ \\
\hline
\end{tabular}

Conforme os dados acima, nota-se que Serra concentrou a maior parte de seus gastos no segundo mês eleitoral (agosto), contrário dos outros três candidatos, na tentativa de retornar ao segundo posto nas pesquisas de intenção de voto e de garantir sua vaga no segundo turno.

O candidato tucano também despendeu grande parte de seus recursos no terceiro período eleitoral (de 1.9.02 a 6.10.02), como forma de garantir o segundo lugar. Ressalte-se que mesmo com o valor gasto no terceiro período sendo menor que no segundo mês, o valor despendido por Serra é maior que a soma dos valores gastos por Ciro Gomes e Anthony Garotinho no mesmo período.

No afã de conseguir a vaga no segundo turno, no entanto, José Serra viu-se sem recursos financeiros para a disputa com Lula: enquanto que as despesas do tucano no segundo e terceiro período eleitoral foram de quase $\mathrm{R} \$ 26$ milhões, no período do segundo turno (de 7 a 27 de outubro) despendeu apenas R \$ 5,5 milhões, e após 28 de outubro (classificado como período pós-eleitoral), houve o dispêndio de R \$ 1,6 milhão.

Lula, ao contrário, gastou 54,6\% de seus recursos (R \$ 11,5 milhões) no próprio segundo turno, garantindo assim sua vitória sem percalços sobre José Serra. Percebe-se também que a candidatura Serra na verdade viveu uma asfixia financeira, posto que foi a única dentre as quatro candidaturas que teve saldo negativo nas contas de campanha, conforme se vê adiante: 
Tabela 13 - Saldo Financeiro das Campanhas

\begin{tabular}{|l|r|}
\hline & Saldo de Campanha \\
\hline Ciro Gomes & $\mathrm{R} \$ 4.831,66$ \\
\hline Garotinho & $\mathrm{R} \$ 67.643,10$ \\
\hline Serra & $-\mathrm{R} \$ 6.176 .274,22$ \\
\hline Lula & $\mathrm{R} \$ 11.203,41$ \\
\hline
\end{tabular}

As campanhas de Ciro Gomes, Anthony Garotinho e Luiz Inácio Lula da Silva tiveram pequenos saldos positivos, mesmo assumindo obrigações durante as eleições e pagando-as somente após o período eleitoral. A candidatura de José Serra, entretanto, ainda conseguiu fazer alguns pagamentos após a eleição, mas deixou uma dívida de mais de R \$ 6,1 milhões, dívida essa assumida pelo PSDB.

Quanto ao tipo de gastos, as despesas entre os quatro candidatos foram bastante parecidas. Entre os dois postulantes derrotados já no primeiro turno, ambos concentraram seus gastos principalmente em propaganda, ficando em segundo lugar nas despesas eleitorais os gastos relativos a transporte.

Tabela 14 - Tipos de Gastos Eleitorais (Ciro Gomes e Anthony Garotinho)

\begin{tabular}{|l|r|r|r|r|}
\hline & \multicolumn{2}{|c|}{ Ciro Gomes } & \multicolumn{2}{c|}{ Garotinho } \\
\hline Encargos & $\mathrm{R} \$ 249.695,77$ & $1,8 \%$ & $\mathrm{R} \$ 12.456,49$ & $0,4 \%$ \\
\hline Propaganda & $\mathrm{R} \$ 10.286 .267,56$ & $73,8 \%$ & $\mathrm{R} \$ 2.117 .069,53$ & $65,9 \%$ \\
\hline Pessoal & $\mathrm{R} \$ 242.094,03$ & $1,7 \%$ & $\mathrm{R} \$ 83,65$ & $0,0 \%$ \\
\hline Serviços & $\mathrm{R} \$ 715.407,63$ & $5,1 \%$ & $\mathrm{R} \$ 52.500,00$ & $1,6 \%$ \\
\hline Infra-estrutura & $\mathrm{R} \$ 545.770,19$ & $3,9 \%$ & $\mathrm{R} \$ 26.061,45$ & $0,8 \%$ \\
\hline Diversas & $\mathrm{R} \$ 295.588,27$ & $2,1 \%$ & $\mathrm{R} \$ 0,00$ & $0,0 \%$ \\
\hline Doações & $\mathrm{R} \$ 17.200,00$ & $0,1 \%$ & $\mathrm{R} \$ 0,00$ & $0,0 \%$ \\
\hline Transporte & $\mathrm{R} \$ 1.586 .021,04$ & $11,4 \%$ & $\mathrm{R} \$ 1.003 .262,78$ & $31,2 \%$ \\
\hline TOTAL & $\mathrm{R} \$ 13.938 .044,49$ & $100,0 \%$ & $\mathrm{R} \$ 3.211 .433,90$ & $100,0 \%$ \\
\hline
\end{tabular}

Ciro Gomes despendeu 73,8\% de seus gastos com todos os tipos de propaganda. Garotinho gastou um pouco menos, mas ainda assim configurando a maior parte de seus gastos: 65,9\%. Em relação a transportes, Garotinho gastou o equivalente a 31,2\% de suas despesas no item; já Ciro, 11,4\%. Ganha destaque também nessa tabela o fato de Garotinho ter gasto ínfimo no item "Pessoal". Essa ocorrência pode ser explicada pelo fato de alguns candidatos colocarem em suas prestações de contas os gastos relativos à 
remuneração pelo trabalho dos funcionários de campanha, como cabos eleitorais, motoristas, secretarias, assessores e telefonistas, por exemplo, no item "Serviços prestados por terceiros", e não em "Pessoal", como deve ser feito, já que o item referente a serviços serve para o pagamento de pessoas físicas e jurídicas que prestem serviços à candidatura em caráter eventual, e não em uma relação de trabalho.

Os gastos eleitorais feitos por José Serra e Luiz Inácio Lula da Silva também demonstram que o item "Propaganda" é fundamentalmente o mais importante em uma eleição presidencial.

Tabela 15 - Tipos de Gastos Eleitorais (José Serra e Luiz Inácio Lula da Silva)

\begin{tabular}{|l|r|r|r|r|}
\hline & \multicolumn{2}{|c|}{ Serra } & \multicolumn{2}{c|}{ Lula } \\
\hline Encargos & $\mathrm{R} \$ 488.898,27$ & $1,4 \%$ & $\mathrm{R} \$ 160.408,65$ & $0,8 \%$ \\
\hline Propaganda & $\mathrm{R} \$ 21.869 .815,60$ & $63,0 \%$ & $\mathrm{R} \$ 17.183 .698,41$ & $81,6 \%$ \\
\hline Pessoal & $\mathrm{R} \$ 130.359,84$ & $0,4 \%$ & $\mathrm{R} \$ 698.044,90$ & $3,3 \%$ \\
\hline Serviços & $\mathrm{R} \$ 6.080 .042,13$ & $17,5 \%$ & $\mathrm{R} \$ 913.201,62$ & $4,3 \%$ \\
\hline Infra-estrutura & $\mathrm{R} \$ 2.727 .221,71$ & $7,9 \%$ & $\mathrm{R} \$ 193.362,01$ & $0,9 \%$ \\
\hline Diversas & $\mathrm{R} \$ 0,00$ & $0,0 \%$ & $\mathrm{R} \$ 145.018,22$ & $0,7 \%$ \\
\hline Doações & $\mathrm{R} \$ 310.000,00$ & $0,9 \%$ & $\mathrm{R} \$ 15.000,00$ & $0,1 \%$ \\
\hline Transporte & $\mathrm{R} \$ 3.110 .198,47$ & $9,0 \%$ & $\mathrm{R} \$ 1.752 .538,76$ & $8,3 \%$ \\
\hline TOTAL & $\mathrm{R} \$ 34.716 .536,02$ & $100,0 \%$ & $\mathrm{R} \$ 21.061 .272,57$ & $100,0 \%$ \\
\hline
\end{tabular}

Os itens transporte e propaganda, da mesma forma que nas candidaturas de Ciro Gomes e Anthony Garotinho, surgem como destaque nas contas de Serra e Lula. O item "propaganda" foi o responsável por $63 \%$ dos gastos da campanha tucana e $81,6 \%$ da campanha petista. Já o item transporte aparece com 9\% (Serra) e 8,3\% (Lula). Outros dois tipos de gastos são significativos na campanha de Serra: serviços $(17,5 \%)$ e infraestrutura $(7,9 \%)$.

É bastante provável que o mesmo erro feito pela campanha de Garotinho tenha ocorrido na campanha de Serra: a alocação de gastos com a remuneração de funcionários de campanha no item "serviços", ao invés de "pessoal". O pequeno gasto de Lula com infra-estrutura (apenas 0,9\%) pode ser explicado, provavelmente, por dois motivos: (i) a utilização da estrutura do próprio partido já existente (e não contabilizada na prestação de contas do candidato); ou (ii) o dispêndio desse item foi contabilizado na prestação de contas do Comitê Financeiro. 
Estudada a eleição presidencial de 2002, passar-se-á à análise das prestações de contas da eleição presidencial de 2006, para que depois possa ser feita uma comparação entre as duas eleições.

\section{3.. Eleição Presidencial de 2006}

Nas eleições de 2006, foram candidatos Luiz Inácio Lula da Silva (PT, postulante à reeleição), o ex-governador de São Paulo Geraldo Alckmin (PSDB), a então senadora por Alagoas Heloísa Helena (PSOL) e o senador pelo Distrito Federal, ex-governador e ex-ministro da Educação Cristovam Buarque (PDT).

Também foram candidatos Ana Maria Rangel (PRP), José Maria Eymael (PSDC), Luciano Bivar (PSL) e Rui Costa Pimenta (PCO). Esses quatro candidatos, porém, não serão estudados, vez que tiveram votação muito baixa (menor que $1 \%$ dos votos válidos), além de serem de partidos com pequena representatividade no cenário político brasileiro (nenhum dos quatro partidos conseguiu eleger um deputado federal em 2006).

O primeiro turno, que ocorreu em $1^{\circ}$ de outubro de 2006 , teve o seguinte resultado:

Tabela 16 - Resultado $1^{\circ}$ Turno Eleição Presidencial (1.10.2006)

\begin{tabular}{|l|l|r|r|}
\hline \multicolumn{1}{|c|}{ Candidato } & Partido & \multicolumn{1}{c|}{ Votos Nominais } & Votos Válidos \\
\hline LUIZ INÁCIO LULA DA SILVA & PT & 46.662 .365 & $48,61 \%$ \\
\hline GERALDO ALCKMIN & PSDB & 39.968 .369 & $41,64 \%$ \\
\hline HELOÍSA HELENA & PSOL & 6.575 .393 & $6,85 \%$ \\
\hline CRISTOVAM BUARQUE & PDT & 2.538 .844 & $2,64 \%$ \\
\hline ANA MARIA RANGEL & PRP & 126.404 & $0,13 \%$ \\
\hline JOSÉ MARIA EYMAEL & PSDC & 63.294 & $0,07 \%$ \\
\hline LUCIANO BIVAR & PSL & 62.064 & $0,06 \%$ \\
\hline RUI COSTA PIMENTA & PCO & 0 & $0,00 \%$ \\
\hline
\end{tabular}

Assim sendo, Lula e Alckmin passaram ao segundo turno, que ocorreu em 29 de outubro de 2006, com o seguinte resultado: 
Tabela 17 - Resultado $2^{\circ}$ Turno Eleição Presidencial (29.10.2006)

\begin{tabular}{|l|l|r|r|}
\hline Candidato & Partido & Votos Nominais & Votos Válidos \\
\hline LUIZ INÁCIO LULA DA SILVA & PT & 58.295 .042 & $60,83 \%$ \\
\hline GERALDO ALCKMIN & PSDB & 37.543 .178 & $39,17 \%$ \\
\hline
\end{tabular}

Nas eleições de 2006, tanto Lula como Alckmin tiveram duas prestações de contas: a da própria candidatura e a do respectivo Comitê Financeiro. Já Heloísa Helena prestou contas de sua campanha apenas por meio de seu Comitê. Cristovam Buarque, ao contrário, não apresentou nenhuma conta do Comitê, havendo apenas a conta de sua candidatura.

Assim sendo, serão estudadas, no caso de Cristovam Buarque e Heloísa Helena, as prestações de contas disponíveis. Quanto ao candidato à reeleição Luiz Inácio Lula da Silva, será analisada a prestação de contas de sua candidatura, pelos motivos expostos no item 5.1 deste trabalho.

Quanto a Geraldo Alckmin, entretanto, será analisada a conta apresentada por seu Comitê Financeiro, e não a de sua candidatura. Isso se deve ao fato de que na prestação de contas em nome de sua candidatura, haver apenas receitas advindas do próprio Comitê - na há nenhuma outra fonte. Além disso, as despesas referentes às contas da candidatura são todas de um tipo só, "Baixa de Recursos Estimáveis". Configura-se, portanto em doação de bens ou serviços do comitê à candidatura, como já explicado no item 5.1, não havendo a prestação de contas da candidatura Alckmin nenhuma serventia para os fins dessa pesquisa.

Como no subitem anterior, referente à eleição de 2002, primeiro serão examinadas as informações sobre a arrecadação das quatro principais campanhas presidenciais, e após serão analisadas os gastos eleitorais feitos pelos quatro postulantes ao Palácio do Planalto.

Quanto à origem dos recursos doados, há uma novidade em relação a 2002 e ao apontado pelos estudiosos do tema. A candidata Helísa Helena, do então recém criado 
PSOL, tem sua campanha baseada nas doações feitas pelo próprio partido e nas pessoas físicas, conforme se depreende da leitura da tabela abaixo:

Tabela 18 - Origem da Arrecadação (Heloísa Helena e Cristovam Buarque)

\begin{tabular}{|l|r|r|r|r|}
\hline & \multicolumn{2}{|c|}{ Heloísa Helena } & \multicolumn{2}{c|}{ Cristovam } \\
\hline Comercialização & $\mathrm{R} \$ 0,00$ & $0,0 \%$ & $\mathrm{R} \$ 0,00$ & $0,0 \%$ \\
\hline $\begin{array}{l}\text { Comitês, Partidos e } \\
\text { Candidatos }\end{array}$ & $\mathrm{R} \$ 313.966,63$ & $83,2 \%$ & $\mathrm{R} \$ 144,28$ & $0,0 \%$ \\
\hline Pessoas Físicas & $\mathrm{R} \$ 61.555,32$ & $16,3 \%$ & $\mathrm{R} \$ 310.810,00$ & $18,1 \%$ \\
\hline Pessoas Jurídicas & $\mathrm{R} \$ 2.007,84$ & $0,5 \%$ & $\mathrm{R} \$ 1.405 .200,00$ & $81,9 \%$ \\
\hline Recursos Não Identificados & $\mathrm{R} \$ 0,00$ & $0,0 \%$ & $\mathrm{R} \$ 0,00$ & $0,0 \%$ \\
\hline TOTAL & $\mathrm{R} \$ 377.529,79$ & $100,0 \%$ & $\mathrm{R} \$ 1.716 .154,28$ & $100,0 \%$ \\
\hline
\end{tabular}

Na campanha da socialista, $83,2 \%$ dos recursos arrecadados vieram do próprio partido, de comitês financeiros de outras campanhas da legenda ou de recursos arrecadados por outros candidatos do partido. Ressaltando a novidade, apenas $0,5 \%$ dos recursos arrecadados por Heloísa Helena vieram de pessoas jurídicas (um montante de pouco mais de $\mathrm{R} \$ 2$ mil), sendo todo o resto dos recursos com origem em doações feitas por pessoas físicas.

Já a campanha de Cristovam segue a linha das demais candidaturas aqui estudadas, sendo predominante as doações de pessoas jurídicas (81,9\%). As doações de pessoas físicas representaram $18,1 \%$ do montante angariado. Houve uma doação do próprio PDT a Cristovam, que não representa nem ao menos $0,1 \%$. Quanto aos candidatos Lula e Alckmin, há também uma novidade, conforme se vê na tabela adiante:

Tabela 19 - Origem da Arrecadação (Luiz Inácio Lula da Silva e Geraldo Alckmin)

\begin{tabular}{|l|r|r|r|r|}
\hline & \multicolumn{2}{|c|}{ Lula } & \multicolumn{2}{c|}{ Alckmin } \\
\hline Comercialização & $\mathrm{R} \$ 584.489,28$ & $0,7 \%$ & $\mathrm{R} \$ 0,00$ & $0,0 \%$ \\
\hline $\begin{array}{l}\text { Comitês, Partidos e } \\
\text { Candidatos }\end{array}$ & $\mathrm{R} \$ 79.183 .636,01$ & $97,5 \%$ & $\mathrm{R} \$ 8.259 .382,10$ & $13,3 \%$ \\
\hline Pessoas Físicas & $\mathrm{R} \$ 159.362,75$ & $0,2 \%$ & $\mathrm{R} \$ 2.724 .592,10$ & $4,4 \%$ \\
\hline Pessoas Jurídicas & $\mathrm{R} \$ 1.260 .809,97$ & $1,6 \%$ & $\mathrm{R} \$ 51.032 .396,25$ & $82,3 \%$ \\
\hline Recursos Não Identificados & $\mathrm{R} \$ 0,00$ & $0,0 \%$ & $\mathrm{R} \$ 6.000,00$ & $0,0 \%$ \\
\hline & & 100,0 & & 100,0 \\
TOTAL & $\mathrm{R} \$ 81.188 .298,01$ & $\%$ & $\mathrm{R} \$ 62.022 .370,45$ & $\%$ \\
\hline
\end{tabular}


A primeira diferença refere-se ao fato de que a candidatura Lula foi a única entre os presidenciáveis que arrecadou recursos por meio da comercialização de bens ou realização de eventos, montantes este que somou quase $\mathrm{R} \$ 600$ mil, representando 0,7\% do montante total arrecadado.

No entanto, a arrecadação proveniente de comitês financeiros (da própria candidatura ou de outras), do próprio partido (do diretório nacional, de diretórios regionais e municipais) e de outras candidaturas representaram 97,5\% da arrecadação total da candidatura. Conforme já explicado anteriormente, doadores por vezes preferem doar via comitê para que a doação não fique vinculada a um candidato; da mesma forma, outros doadores preferem doar pelos diretórios partidários para que essa doação seja publicada pela Justiça Eleitoral à mídia e à sociedade apenas em abril do ano seguinte ao da realização da eleição.

Quanto à candidatura tucana, a predominância das doações de pessoas jurídicas (82,3\% do total arrecadado), havendo significante participação das doações efetuadas pelo partido e pelos comitês financeiros de outras candidaturas. As pessoas físicas doaram apenas 4,4\% do total arrecadado. Houve $\mathrm{R} \$ 6$ mil em doações cujo doador não foi devidamente identificado. Essa doação, no entanto, não configurou ao menos $0,1 \%$ do montante total arrecadado.

Quanto ao meio de realização da doação, não é possível fazer esta análise nas contas das eleições de 2006, simplesmente porque a prestação de contas disponibilizada pelo TSE não traz a informação sobre o meio utilizado para a doação. Há somente a possibilidade de se saber se houve doação em bens ou serviços estimáveis em dinheiro, a ser analisada no momento de exame dos tipos de gastos eleitorais efetuados pelos candidatos.

Quanto ao período de arrecadação, a campanha de Heloísa Helena também se destaca, visto que concentrou a maior parte de sua arrecadação em dois momentos: no primeiro mês eleitoral e principalmente no período pós-eleitoral. Isso pode denotar a dificuldade da candidata em arrecadar recursos, visto que o PSOL, em ditame estatutário, não arrecada recursos para suas campanhas eleitorais com pessoas jurídicas. 
Assim, diante desse fato, Heloísa Helena fez seus gastos eleitorais, realizando a quitação da maioria dos mesmos somente após o dia da eleição do primeiro turno $\left(01^{\circ}\right.$ de outubro de 2006), uma vez que arrecadou 45,4\% de seu montante total somente após a eleição, conforme tabela abaixo:

Tabela 20 - Período de Arrecadação (Heloísa Helena e Cristovam Buarque)

\begin{tabular}{|l|r|r|r|r|}
\hline & \multicolumn{2}{|c|}{ Heloísa Helena } & \multicolumn{2}{c|}{ Cristovam } \\
\hline Período Pré-Eleitoral & $\mathrm{R} \$ 0,00$ & $0,0 \%$ & $\mathrm{R} \$ 0,00$ & $0,0 \%$ \\
\hline $\mathbf{1}^{\mathbf{0}}$ Mês Eleitoral & $\mathrm{R} \$ 102.966,04$ & $27,3 \%$ & $\mathrm{R} \$ 135.000,00$ & $7,9 \%$ \\
\hline $\mathbf{2}^{\mathbf{0}}$ Mês Eleitoral & $\mathrm{R} \$ 70.170,75$ & $18,6 \%$ & $\mathrm{R} \$ 815.154,28$ & $47,5 \%$ \\
\hline $\mathbf{3}^{\circ}$ Mês Eleitoral & $\mathrm{R} \$ 33.043,00$ & $8,8 \%$ & $\mathrm{R} \$ 367.000,00$ & $21,4 \%$ \\
\hline Período Pós-Eleitoral & $\mathrm{R} \$ 171.350,00$ & $45,4 \%$ & $\mathrm{R} \$ 399.000,00$ & $23,2 \%$ \\
\hline TOTAL & $\mathrm{R} \$ 377.529,79$ & $100,0 \%$ & $\mathrm{R} \$ 1.716 .154,28$ & $100,0 \%$ \\
\hline
\end{tabular}

Cristovam Buarque, diferentemente da candidata socialista, concentrou sua arrecadação em agosto (47,5\% do montante arrecadado), distribuindo outros $44 \%$ no terceiro período eleitoral e após as eleições.

Já Lula e Alckmin também tiveram períodos diferentes de arrecadação, conforme a tabela adiante:

Tabela 21 - Período de Arrecadação (Luiz Inácio Lula da Silva e Geraldo Alckmin)

\begin{tabular}{|l|r|r|r|r|}
\hline & \multicolumn{2}{|c|}{ Lula } & \multicolumn{2}{c|}{ Alckmin } \\
\hline Período Pré-Eleitoral & $\mathrm{R} \$ 0,00$ & $0,0 \%$ & $\mathrm{R} \$ 0,00$ & $0,0 \%$ \\
\hline $\mathbf{1}^{\mathbf{0}}$ Mês Eleitoral & $\mathrm{R} \$ 3.419 .970,52$ & $4,2 \%$ & $\mathrm{R} \$ 1.322 .697,58$ & $2,2 \%$ \\
\hline $\mathbf{2}^{\mathbf{o}}$ Mês Eleitoral & $\mathrm{R} \$ 11.684 .518,95$ & $14,4 \%$ & $\mathrm{R} \$ 19.718 .584,88$ & $32,3 \%$ \\
\hline $\mathbf{3}^{\mathbf{0}}$ Mês Eleitoral & $\mathrm{R} \$ 21.847 .940,66$ & $26,9 \%$ & $\mathrm{R} \$ 15.557 .727,59$ & $25,5 \%$ \\
\hline Segundo Turno & $\mathrm{R} \$ 15.773 .927,50$ & $19,4 \%$ & $\mathrm{R} \$ 21.915 .504,16$ & $35,9 \%$ \\
\hline Período Pós-Eleitoral & $\mathrm{R} \$ 28.461 .940,38$ & $35,1 \%$ & $\mathrm{R} \$ 2.507 .856,24$ & $4,1 \%$ \\
\hline TOTAL & $\mathrm{R} \$ 81.188 .298,01$ & $100,0 \%$ & $\mathrm{R} \$ 61.022 .370,45$ & $100,0 \%$ \\
\hline
\end{tabular}

O principal período de arrecadação do candidato petista foi o período pós eleitoral: mais um caso de candidato que faz o gasto sem ter dinheiro suficientemente arrecadado para tanto, deixando o pagamento para somente depois da eleição (no caso, 29 de outubro, visto que disputou o segundo turno). No período eleitoral, Lula 
arrecadou recursos principalmente no terceiro período eleitoral $\left(1^{\circ}\right.$ de setembro até $1^{\circ}$ de outubro, dia da eleição), numa provável tentativa de vencer a eleição já no primeiro turno, conforme indicam as pesquisas de opinião realizadas pelo Datafolha abaixo apresentadas:

Tabela 22 - Pesquisas de Intenção de Voto $1^{\circ}$ Turno (Datafolha) ${ }^{412}$

\begin{tabular}{|c|c|c|c|c|c|c|c|c|c|c|c|}
\hline & $\begin{array}{l}28 \text { e } \\
29 / 6\end{array}$ & $\begin{array}{l}17 \mathrm{e} \\
18 / 7\end{array}$ & $\begin{array}{l}7 \text { e } \\
8 / 8\end{array}$ & $\begin{array}{l}21 \text { e } \\
22 / 8\end{array}$ & $29 / 8$ & $\begin{array}{l}4 \mathrm{e} \\
5 / 9 \\
\end{array}$ & $\begin{array}{l}11 \mathrm{e} \\
12 / 9\end{array}$ & $\begin{array}{l}18 \mathrm{e} \\
19 / 9\end{array}$ & $22 / 9$ & $27 / 9$ & $30 / 9$ \\
\hline Lula & 46 & 44 & 47 & 49 & 50 & 51 & 50 & 50 & 49 & 49 & 46 \\
\hline Alckmin & 29 & 28 & 24 & 25 & 27 & 27 & 28 & 29 & 31 & 33 & 35 \\
\hline $\begin{array}{l}\text { Heloísa } \\
\text { Helena } \\
\end{array}$ & 6 & 10 & 12 & 11 & 10 & 9 & 9 & 9 & 7 & 8 & 8 \\
\hline
\end{tabular}

Lula sempre liderou as pesquisas de intenção de voto nas eleições de 2006, além de seus índices sempre ficarem próximos a uma possível vitória já no primeiro turno. Essa impressão foi acentuada no final de agosto, quando o candidato à reeleição atingiu o patamar de $50 \%$ das intenções de voto. Porém, no final de setembro, o candidato tucano conseguiu reagir, levando a disputa ao segundo turno.

Já no segundo turno Alckmin arrecadou praticamente 50\% mais de recursos que o candidato à reeleição. Este fato pode ter pode ter ocorrido pelo fato de Alckmin, no início do segundo turno, ter se aproximado de Lula na pesquisa de intenções de votos, conforme se vê a seguir:

Tabela 23 - Pesquisas de Intenção de Voto $2^{\circ}$ Turno (Datafolha) ${ }^{413}$

\begin{tabular}{|l|c|c|c|c|c|}
\hline & $\mathbf{5}$ e 6/10 & $\mathbf{1 0 / 1 0}$ & $\mathbf{1 6}$ e 17/10 & $\mathbf{2 3}$ e 24/10 & $\mathbf{2 8 / 1 0}$ \\
\hline Lula & 50 & 51 & 57 & 58 & 58 \\
\hline Alckmin & 43 & 40 & 38 & 37 & 37 \\
\hline
\end{tabular}

Na pesquisa realizada logo após a realização do primeiro turno, Alckmin havia diminuído a diferença para Lula, o que poderia significar maior equilíbrio na disputa eleitoral. Seus potenciais doadores, interessados em sua vitória, aportaram mais dinheiro na campanha tucana neste período, visando à derrota de Lula. Na pesquisa seguinte,

${ }^{412}$ Pesquisas disponíveis em: <http://datafolha.folha.uol.com.br/po/ver_po.php?session=309>. Último acesso em 12.12.2009.

${ }_{413}$ Pesquisas disponíveis em: <http://datafolha.folha.uol.com.br/po/ver_po.php?session=323〉. Último acesso em 12.12.2009. 
todavia, Lula novamente consegue abrir boa vantagem, consolidando sua segunda vitória na eleição presidencial com bastante folga.

No que toca ao período em que são feitas as despesas, vê-se da mesma forma que nas despesas, que Alckmin gastou a maior parte de seus recursos no segundo turno, como forma de tentar vencer Lula.

Enquanto que em 2002 José Serra teve que gastar boa parte do montante arrecadado no primeiro turno, no intuito de conseguir um dos dois postos no segundo turno, em ferrenha disputa com Ciro Gomes e Anthony Garotinho, Alckmin também teve que fazer grandes despesas no primeiro turno, mas por outro motivo: tentar fazer com que o segundo turno houvesse.

Como já visto nas pesquisas de intenção de voto na Tabela 22, o candidato do PSDB não foi em nenhum momento ameaçado por Heloísa Helena, tampouco por Cristovam Buarque, que nunca passou do índice de dois pontos percentuais nas pesquisas de intenção de voto do Datafolha. A luta de Alckmin era a de fazer Lula não vencer já no primeiro turno, o que o fez gastar muitos recursos nos três primeiros períodos eleitorais, conforme tabela adiante:

Tabela 24 - Período de Gastos Eleitorais (Luiz Inácio Lula da Silva e Geraldo Alckmin)

\begin{tabular}{|c|c|c|c|c|}
\hline & \multicolumn{2}{|l|}{ Lula } & \multicolumn{2}{|l|}{ Alckmin } \\
\hline Período Pré-Eleitoral & $\mathrm{R} \$ 0,00$ & $0,0 \%$ & $\mathrm{R} \$ 3,75$ & $0,0 \%$ \\
\hline $\mathbf{1}^{\circ}$ Mês Eleitoral & $\mathrm{R} \$ 2.631 .852,54$ & $2,9 \%$ & $\mathrm{R} \$ 788.310,17$ & $1,0 \%$ \\
\hline $2^{\circ}$ Mês Eleitoral & $\mathrm{R} \$ 11.609 .985,89$ & $12,7 \%$ & $\mathrm{R} \$ 14.090 .486,30$ & $17,2 \%$ \\
\hline $3^{\circ}$ Mês Eleitoral & $\mathrm{R} \$ 18.955 .795,91$ & $20,7 \%$ & $\mathrm{R} \$ 20.358 .182,94$ & $24,9 \%$ \\
\hline Segundo Turno & $\mathrm{R} \$ 15.626 .827,34$ & $17,1 \%$ & $\mathrm{R} \$ 21.079 .394,00$ & $25,7 \%$ \\
\hline Período Pós-Eleitoral & $\mathrm{R} \$ 26.377 .015,35$ & $28,8 \%$ & $\mathrm{R} \$ 3.104 .389,76$ & $3,8 \%$ \\
\hline Sem Data ${ }^{414}$ & $\mathrm{R} \$ 16.289 .193,68$ & $17,8 \%$ & $\mathrm{R} \$ 22.502 .857,83$ & $27,5 \%$ \\
\hline TOTAL & $\mathrm{R} \$ 91.490 .670,71$ & $100,0 \%$ & $\mathrm{R} \$ 81.923 .624,75$ & $100,0 \%$ \\
\hline
\end{tabular}

\footnotetext{
${ }^{414}$ Os gastos classificados como "Sem Data", em sua grande maioria, consiste nas doações feitas em bens ou serviços estimáveis em dinheiro que no programa SPCE aparece automaticamente como despesas eleitorais do tipo "Baixa Recursos Estimáveis", ocorrência explicada com mais detalhes no item 5.1. Esses gastos, porém, não aparecem com data nas prestações de contas disponíveis no sítio eletrônico do TSE. Há casos também em que o gasto eleitoral - mesmo não sendo do tipo de doação estimada automaticamente convertida em despesa - foi registrado sem a data da ocorrência.
} 
Já a campanha de Lula teve seus gastos distribuídos entre os períodos, havendo maiores despesas no período pós-eleitoral (ou seja, a partir de 30 de outubro de 2006), com $28,8 \%$ do montante gasto. No período de eleições, Lula gastou a maior parte no terceiro mês eleitoral (na tentativa de já vencer no primeiro turno) e no próprio segundo turno.

Chama a atenção, no entanto, a diferença tanto na arrecadação quanto nos gastos na comparação entre Lula e Alckmin no período pós-eleitoral. Já eleito, Lula arrecadou quase R $\$ 28,5$ milhões (35,1\% do total arrecadado); Alckmin, apenas R 2,5 milhões (4,1\% do seu respectivo montante arrecadado). Nos gastos, o petista despendeu R $\$ 26,3$ milhões em obrigações contraídas no período eleitoral, porém só quitadas após 29 de outubro de 2006. Em contrapartida, o tucano gastou apenas R \$ 3,1 milhões.

Nota-se claramente que após eleito, Lula consegue arrecadar muito mais que o candidato tucano derrotado. É forçoso reconhecer que ao contrário da doação no período eleitoral, momento em que a disputa ainda está ocorrendo e que há o interesse do doador na vitória de um candidato ou na derrota de outro, no período pós-eleitoral as doações ocorrem normalmente sem qualquer vinculação a um possível resultado eleitoral positivo aos seus interesses: lida-se nesse caso com o resultado já posto, sendo possivelmente interessante ajudar o vencedor do pleito nas suas dívidas de campanha, para no futuro conseguir algo em troca.

Nas campanhas de Heloísa Helena e Cristovam Buarque, as despesas póseleitorais foram bem menos significativas em comparação à candidatura de Luiz Inácio Lula da Silva, conforme se vê na tabela adiante 
Tabela 25 - Período de Gastos Eleitorais (Heloísa Helena e Cristovam Buarque)

\begin{tabular}{|l|r|r|r|r|}
\hline & \multicolumn{2}{|c|}{ Heloísa Helena } & \multicolumn{2}{c|}{ Cristovam } \\
\hline Período Pré-Eleitoral & $\mathrm{R} \$ 0,00$ & $0,0 \%$ & $\mathrm{R} \$ 0,00$ & $0,0 \%$ \\
\hline $\mathbf{1}^{\mathbf{0}}$ Mês Eleitoral & $\mathrm{R} \$ 0,00$ & $0,0 \%$ & $\mathrm{R} \$ 60.286,11$ & $3,5 \%$ \\
\hline $\mathbf{2}^{\mathbf{0}}$ Mês Eleitoral & $\mathrm{R} \$ 47.800,00$ & $12,7 \%$ & $\mathrm{R} \$ 676.078,66$ & $39,4 \%$ \\
\hline $\mathbf{3}^{\mathbf{o}}$ Mês Eleitoral & $\mathrm{R} \$ 30.423,99$ & $8,1 \%$ & $\mathrm{R} \$ 529.667,70$ & $30,9 \%$ \\
\hline Segundo Turno & $\mathrm{R} \$ 0,00$ & $0,0 \%$ & $\mathrm{R} \$ 0,00$ & $0,0 \%$ \\
\hline Período Pós-Eleitoral & $\mathrm{R} \$ 10.475,91$ & $2,8 \%$ & $\mathrm{R} \$ 239.432,72$ & $14,0 \%$ \\
\hline Sem Data & $\mathrm{R} \$ 288.822,78$ & $76,5 \%$ & $\mathrm{R} \$ 210.255,23$ & $12,3 \%$ \\
\hline TOTAL & $\mathrm{R} \$ 377.522,68$ & $100,0 \%$ & $\mathrm{R} \$ 1.715 .720,42$ & $100,0 \%$ \\
\hline
\end{tabular}

Na campanha de Heloísa Helena, destacam-se os gastos sem data, visto que suas receitas vieram principalmente de bens e serviços estimáveis em dinheiro de seu partido, conforme se verá adiante. Na campanha de Cristovam, diferentemente, mais de $70 \%$ de seus gastos se deu no período eleitoral, sem contar os gastos "sem data", nos quais boa parte também deve ter ocorrido no período eleitoral.

A análise dos tipos de despesas confirmou mais uma vez que a propaganda é o centro principal dos gastos eleitorais. Três dos quatro candidatos tiveram esse item como o foco de suas despesas, conforme a tabela a seguir:

Tabela 26 - Tipos de Gastos Eleitorais (Heloísa Helena e Cristovam Buarque)

\begin{tabular}{|l|r|r|r|r|}
\hline & \multicolumn{2}{|c|}{ Heloísa Helena } & \multicolumn{2}{c|}{ Cristovam } \\
\hline Encargos & $\mathrm{R} \$ 463,13$ & $0,1 \%$ & $\mathrm{R} \$ 10.159,14$ & $0,6 \%$ \\
\hline Propaganda & $\mathrm{R} \$ 72.700,00$ & $19,3 \%$ & $\mathrm{R} \$ 1.423 .555,28$ & $83,0 \%$ \\
\hline Pessoal & $\mathrm{R} \$ 0,00$ & $0,0 \%$ & $\mathrm{R} \$ 76.577,75$ & $4,5 \%$ \\
\hline Serviços & $\mathrm{R} \$ 0,00$ & $0,0 \%$ & $\mathrm{R} \$ 34.346,36$ & $2,0 \%$ \\
\hline Infra-estrutura & $\mathrm{R} \$ 3.356,36$ & $0,9 \%$ & $\mathrm{R} \$ 65.098,73$ & $3,8 \%$ \\
\hline Diversas & $\mathrm{R} \$ 4.249,88$ & $1,1 \%$ & $\mathrm{R} \$ 15.045,00$ & $0,9 \%$ \\
\hline Doações & $\mathrm{R} \$ 0,00$ & $0,0 \%$ & $\mathrm{R} \$ 0,00$ & $0,0 \%$ \\
\hline Transporte & $\mathrm{R} \$ 7.930,53$ & $2,1 \%$ & $\mathrm{R} \$ 90.793,88$ & $5,3 \%$ \\
\hline Baixa & $\mathrm{R} \$ 288.822,78$ & $76,5 \%$ & $\mathrm{R} \$ 144,28$ & $0,0 \%$ \\
\hline TOTAL & $\mathrm{R} \$ 377.522,68$ & $100,0 \%$ & $\mathrm{R} \$ 1.715 .720,42$ & $100,0 \%$ \\
\hline
\end{tabular}

Na campanha de Cristovam, $83 \%$ dos gastos eleitorais foram relativos aos diversos tipos de propaganda presentes nas campanhas eleitorais brasileiras. As despesas referentes a remuneração de pessoal, pagamento de itens de infra-estrutura e 
dispêndios com transporte foram os outros itens relevantes dos gastos da campanha do pedetista.

Já o Comitê de Heloísa Helena apresentou dois gastos como os mais proeminentes de sua campanha: a propaganda (19,3\% do montante gasto) e a baixa em recursos estimáveis, com $76,5 \%$ do montante despendido. Conforme anteriormente explicado no item 5.1, toda doação em estimado para uma campanha eleitoral na eleição de 2006, ao ser contabilizada na receita de campanha, gera automaticamente (pelo programa de computador desenvolvido pelo TSE para a prestação de contas, chamado SPCE) uma despesa na prestação, sob o título "baixa de recursos estimáveis".

Assim, na campanha da socialista, seu maior gasto foi justamente nessa modalidade, sem que o eleitor interessado em ver as contas eleitorais de alguns candidatos possa saber qual foi o verdadeiro gasto realizado.

Nas campanhas de Luiz Inácio Lula da Silva e Geraldo Alckmin, os três tipos de gastos predominantes são os mesmos: propaganda, transporte e serviços.

Tabela 27 - Tipos de Gastos Eleitorais (Luiz Inácio Lula da Silva e Geraldo Alckmin)

\begin{tabular}{|l|r|r|r|r|}
\hline & \multicolumn{2}{|c|}{ Lula } & \multicolumn{2}{c|}{ Alckmin } \\
\hline Encargos & $\mathrm{R} \$ 779.155,99$ & $0,9 \%$ & $\mathrm{R} \$ 458.024,89$ & $0,6 \%$ \\
\hline Propaganda & $\mathrm{R} \$ 64.484 .145,04$ & $70,5 \%$ & $\mathrm{R} \$ 60.981 .245,61$ & $74,4 \%$ \\
\hline Pessoal & $\mathrm{R} \$ 192.480,99$ & $0,2 \%$ & $\mathrm{R} \$ 1.680 .946,82$ & $2,1 \%$ \\
\hline Serviços & $\mathrm{R} \$ 6.101 .036,13$ & $6,7 \%$ & $\mathrm{R} \$ 5.859 .357,60$ & $7,2 \%$ \\
\hline Infra-estrutura & $\mathrm{R} \$ 2.083 .496,07$ & $2,3 \%$ & $\mathrm{R} \$ 1.706 .480,01$ & $2,1 \%$ \\
\hline Diversas a especificar & $\mathrm{R} \$ 1.721 .600,06$ & $1,9 \%$ & $\mathrm{R} \$ 13.487,72$ & $0,0 \%$ \\
\hline Doações & $\mathrm{R} \$ 0,00$ & $0,0 \%$ & $\mathrm{R} \$ 0,00$ & $0,0 \%$ \\
\hline Transporte & $\mathrm{R} \$ 10.141 .935,45$ & $11,1 \%$ & $\mathrm{R} \$ 8.626 .030,70$ & $10,5 \%$ \\
\hline Baixa & $\mathrm{R} \$ 5.986 .820,98$ & $6,5 \%$ & $\mathrm{R} \$ 2.598 .051,40$ & $3,2 \%$ \\
\hline TOTAL & $\mathrm{R} \$ 91.490 .670,71$ & $100,0 \%$ & $\mathrm{R} \$ 81.923 .624,75$ & $100,0 \%$ \\
\hline
\end{tabular}

No que toca à propaganda, tanto Lula quanto Alckmin gastaram mais de $70 \%$ do total despendido em no principal item de uma campanha eleitoral $(70,5 \%$ e $74,4 \%$, respectivamente). Para ambos, os gastos com transporte também configuraram as despesas mais importantes após a propaganda: Lula gastou R \$ 10,1 milhões com 
transporte (11,1\% do montante gasto), enquanto Geraldo Alckmin despendeu R\$ 8,6 milhões (10,5\% do montante gasto).

Os gastos em serviços, em infra-estrutura e em encargos apresentaram porcentuais equivalentes. As diferenças ocorreram principalmente nas despesas com a remuneração de pessoal (Lula $0,2 \%$ e Alckmin 2,1\%) e nos recursos recebidos a título de bens ou serviços estimados (Lula 6,5\% e Alckmin 3,2\%).

Por fim, o saldo de campanha é novamente um problema para os candidatos e para os partidos, conforme tabela abaixo:

Tabela 28 - Saldo Financeiro das Campanhas

\begin{tabular}{|l|c|}
\hline & Saldo de campanha \\
\hline Lula & $-\mathrm{R} \$ 10.302 .372,70$ \\
\hline Alckmin & $-\mathrm{R} \$ 19.901 .254,30$ \\
\hline Heloísa Helena & $\mathrm{R} \$ 7,11$ \\
\hline Cristovam & $\mathrm{R} \$ 433,86$ \\
\hline
\end{tabular}

Tanto a campanha de Heloísa Helena como a de Cristovam Buarque apresentaram pequeno saldo positivo. Já as campanhas de Luiz Inácio Lula da Silva e de Geraldo Alckmin tiveram enormes resultados negativos, resultados estes pagos ou pelo comitê financeiro ou pelo próprio partido.

\subsection{Comparativo entre as eleições presidenciais de 2002 e 2006 e a Lei $n$. 11.300/2006}

Conforme já apresentado anteriormente neste trabalho, a primeira grande reforma sofrida pela Lei das Eleições, principalmente nas disposições relativas ao financiamento das campanhas eleitorais aconteceu com o advento da Lei n. 11.300/06. Esta lei tem como principal objetivo, entre muitos outros, a redução dos gastos nas campanhas eleitorais, para que as campanhas precisem de menos dinheiro para sua realização, e por consequiência tornem-se menos dependentes do setor privado. 
Para tanto, foram eliminados do ordenamento jurídico brasileiro algumas espécies tipos de propaganda eleitoral que já estavam há muito tempo arraigadas na cultura político-eleitoral brasileiras, como os outdoors, a distribuição de brindes e os showmícios.

Assim, quer se detectar se houve realmente uma diminuição nos gastos eleitorais, em especial nas despesas com propaganda. Para essa análise, será feita a comparação entre os gastos feitos por Lula em 2002 e em 2006 (nesta última eleição, referida lei já estava em vigor). Serão comparados também os gastos feitos por José Serra em 2002 e Geraldo Alckmin em 2006. Apesar de se tratar de candidatos diferentes, os dois postulantes são do mesmo partido (PSDB). Ademais, foram justamente os dois que participaram do segundo turno contra o atual presidente da República nas últimas duas eleições presidenciais. Assim sendo, há bastante similitude entre as campanhas de Serra e Alckmin: as duas foram patrocinadas pelo mesmo partido; as duas concorreram contra o mesmo adversário pelo mesmo período de tempo.

Na comparação entre as campanhas de Lula em 2002 e em 2006, nota-se uma diminuição na porcentagem referente ao item "propaganda": em 2002, antes das mudanças promovidas pela Lei n. 11.300/06, Lula gastou o equivalente a $81,6 \%$ de sua arrecadação em propaganda; já em 2006, despendeu "apenas” 70,6\%. Somente no item "pessoal" houve queda no percentual apurado de despesa; em todos os outros itens, na verdade houve aumento do percentual.

Tabela 29 - Tipos de Gastos Eleitorais (Luiz Inácio Lula da Silva 2002 e 2006)34

\begin{tabular}{|r|r|c|r|r|}
\hline \multicolumn{2}{|c|}{ Lula 2006 } & \multicolumn{2}{|c|}{ Lula 2002 } \\
\hline $\mathrm{R} \$ 779.155,99$ & $0,9 \%$ & Encargos & $\mathrm{R} \$ 160.408,65$ & $0,8 \%$ \\
\hline $\mathrm{R} \$ 64.484 .145,04$ & $70,5 \%$ & Propaganda & $\mathrm{R} \$ 17.183 .698,41$ & $81,6 \%$ \\
\hline $\mathrm{R} \$ 192.480,99$ & $0,2 \%$ & Pessoal & $\mathrm{R} \$ 698.044,90$ & $3,3 \%$ \\
\hline $\mathrm{R} \$ 6.101 .036,13$ & $6,7 \%$ & Serviços & $\mathrm{R} \$ 913.201,62$ & $4,3 \%$ \\
\hline $\mathrm{R} \$ 2.083 .496,07$ & $2,3 \%$ & $\begin{array}{c}\text { Infra- } \\
\text { estrutura }\end{array}$ & $\mathrm{R} \$ 193.362,01$ & $0,9 \%$ \\
\hline $\mathrm{R} \$ 1.721 .600,06$ & $1,9 \%$ & Diversas & $\mathrm{R} \$ 145.018,22$ & $0,7 \%$ \\
\hline $\mathrm{R} \$ 0,00$ & $0,0 \%$ & Doações & $\mathrm{R} \$ 15.000,00$ & $0,1 \%$ \\
\hline $\mathrm{R} \$ 10.141 .935,45$ & $11,1 \%$ & Transporte & $\mathrm{R} \$ 1.752 .538,76$ & $8,3 \%$ \\
\hline $\mathrm{R} \$ 5.986 .820,98$ & $6,5 \%$ & Baixa & $\mathrm{R} \$ 0,00$ & $0,0 \%$ \\
\hline $\mathrm{R} \$ 91.490 .670,71$ & $100,0 \%$ & TOTAL & $\mathrm{R} \$ 21.061 .272,57$ & $100,0 \%$ \\
\hline
\end{tabular}


Apesar do valor relativo diminuir, o valor nominal explodiu em todos os itens; no item propaganda, o gasto de Lula passou de $R \$ 17,1$ milhões em 2002 para $R \$ 64,5$ milhões em 2006. Nas campanhas presidenciais do PSDB, porém, a Lei n. 11.300/06 não surtiu efeito, conforme a tabela abaixo:

Tabela 30 - Tipos de Gastos Eleitorais (José Serra - 2002 e Geraldo Alckmin 2006)

\begin{tabular}{|r|r|c|r|r|}
\hline \multicolumn{2}{|c|}{ Serra 2002 } & & \multicolumn{2}{|c|}{ Alckmin 2006 } \\
\hline $\mathrm{R} \$ 488.898,27$ & $1,4 \%$ & Encargos & $\mathrm{R} \$ 458.024,89$ & $0,6 \%$ \\
\hline $\mathrm{R} \$ 21.869 .815,60$ & $63,0 \%$ & Propaganda & $\mathrm{R} \$ 60.981 .245,61$ & $74,4 \%$ \\
\hline $\mathrm{R} \$ 130.359,84$ & $0,4 \%$ & Pessoal & $\mathrm{R} \$ 1.680 .946,82$ & $2,1 \%$ \\
\hline $\mathrm{R} \$ 6.080 .042,13$ & $17,5 \%$ & Serviços & $\mathrm{R} \$ 5.859 .357,60$ & $7,2 \%$ \\
\hline $\mathrm{R} \$ 2.727 .221,71$ & $7,9 \%$ & $\begin{array}{c}\text { Infra- } \\
\text { estrutura }\end{array}$ & $\mathrm{R} \$ 1.706 .480,01$ & $2,1 \%$ \\
\hline $\mathrm{R} \$ 0,00$ & $0,0 \%$ & Diversas & $\mathrm{R} \$ 13.487,72$ & $0,0 \%$ \\
\hline $\mathrm{R} \$ 310.000,00$ & $0,9 \%$ & Doações & $\mathrm{R} \$ 0,00$ & $0,0 \%$ \\
\hline $\mathrm{R} \$ 3.110 .198,47$ & $9,0 \%$ & Transporte & $\mathrm{R} \$ 8.626 .030,70$ & $10,5 \%$ \\
\hline $\mathrm{R} \$ 0,00$ & $0,0 \%$ & Baixa & $\mathrm{R} \$ 2.598 .051,40$ & $3,2 \%$ \\
\hline $\mathrm{R} \$ 34.716 .536,02$ & $100,0 \%$ & TOTAL & $\mathrm{R} \$ 81.923 .624,75$ & $100,0 \%$ \\
\hline
\end{tabular}

Nas campanhas presidenciais do PSDB, houve não só a explosão dos valores gastos no total de despesas eleitorais, mas no item propaganda, em especial, as campanhas tucanas passaram de um gasto de R \$21,9 milhões em 2002 com Serra para quase R \$ 61 milhões com Geraldo Alckmin, em 2006

Assim sendo, chega-se à conclusão de que pelo menos nas eleições presidenciais, não há como realmente verificar se a Lei n. 11.300/06 surtiu efeitos, já os gastos relativos com propaganda diminuíram na comparação entre as campanhas de 2002 e 2006 de Lula (PT). No entanto, nas postulações do PSDB ao Palácio do Planalto, houve um aumento do valor relativo gasto com propaganda, impossibilitando uma conclusão com base sólidas ao menos no que diz respeito das eleições presidenciais. 


\section{5 - CONSIDERAÇÕES FINAIS}

Após a análise profunda tanto do contexto político-eleitoral brasileiro como também das nuances e peculiaridades do sistema normativo referente exclusivamente ao financiamento da política no Brasil, pode-se inferir que para o entendimento dos problemas que afligem o sistema atualmente vigente, não basta a análise apenas dos dispositivos legais da Lei das Eleições, da Lei dos Partidos Políticos, do Código Eleitoral e da Lei das Inelegibilidades: deve-se também ver todo o cenário político brasileiro, já que várias outras de sua fragilidades trazem consequiência à prática do financiamento dos partidos políticos e das campanhas eleitorais, entre eles o vigente sistema proporcional de lista aberta, o inchado sistema partidário brasileiro e as regras que disciplinam a propaganda partidária e eleitoral.

Pude perceber também que as principais propostas apresentadas pelo Estado brasileiro e que estão no Congresso Nacional apresentam caminhos bastante diferentes para a tão desejada reforma do panorama político nacional, com destaque às normas do financiamento da atividade política. Como em vários outros temas debatidos no Congresso dentro do grande tema chamado "reforma política", há várias propostas nos mais diversos caminhos diferentes, sendo praticamente impossível chegar a um consenso de qual é a melhor proposta para dirimir os problemas latentes do sistema político brasileiro.

Ademais, as propostas normalmente são para uma mudança profunda, sem se levar em conta todo o histórico da legislação, a cultura política vigente, os usos e costumes (positivos ou negativos) existentes entre àqueles que são afetados diretamente (políticos, operadores do direito, profissionais da área, acadêmicos) ou indiretamente (o eleitorado, ou seja, todos os cidadãos) pelas regras eleitorais hoje vigentes.

Desde 2005, após o escândalo do "mensalão", fato que culminou em uma nova e longa discussão sobre a reforma política (com especial ênfase no financiamento da atividade política), o Congresso aprovou de forma rápida e co poucos debates sobre os reais motivos e as possíveis conseqüências duas novas leis que mudaram bastante e legislação aprovada em 1997. A primeira lei, de n. 11.300/06, não teve seu objetivo 
alcançado na eleição presidencial, conforme se demonstrou no capítulo 4 deste trabalho. Já a Lei n. 12.034/09 só poderá ser testada nas eleições de outubro de 2010.

Independentemente do caminho a ser tomado pela sociedade brasileira, por meio de seus legisladores, no que diz respeito às mudanças nas normas constitucionais e legais que disciplinam a atividade política, vale sempre ressaltar as afirmações de Daniel Zovatto e de Delia Ferreira Rubio sobre a possível reforma legislativa das normas da atividade política nos países latino-americanos.

Zovatto afirma que em um tema tão "complexo, controverso e não-resolvido, para o qual não existem panacéias nem fórmulas mágicas”, deve-se conseguir seu aperfeiçoamento por "aproximações sucessivas", e não por "iniciativas de reforma ampla e muito ambiciosas" 415 , afirmação esta que vai em sentido oposto ao que está sendo proposto na maioria das vezes no Brasil.

Para que uma proposta de reforma política possa realmente fazer com que as eleições sejam mais justas, limpas, normais e legítimas, conforme determina o art. 14 , § $9^{\circ}$ da Constituição, os legisladores devem considerar o contexto histórico e cultural do ambiente político vigente, além de se analisar o sistema partidário, o sistema de governo, as regras eleitorais e por fim as práticas que regem o jogo democrático brasileiro $^{416}$. Sem esses dois ensinamentos em mente, penso que será bastante improvável uma reforma no panorama político (e em especial nas normas de financiamento da política) que possam realmente diminuir todos os problemas apontados neste trabalho.

\footnotetext{
${ }^{415}$ Daniel Zovatto, "Financiamento dos partidos e campanhas eleitorais na América Latina: uma análise comparada", p. 327.

416 Cf. Delia Ferreira Rubio, "Financiamento de partidos e campanhas: fundos públicos versus fundos privados", p. 7.
} 


\section{BIBLIOGRAFIA}

Afonso da Silva, Luís Virgílio. Sistemas eleitorais: tipos, efeitos jurídico-políticos e aplicação ao caso brasileiro. São Paulo: Malheiros, 2002.

Albuquerque, Afonso de. A batalha pela Presidência: o Horário Gratuito de Propaganda Eleitoral na campanha de 1989. Tese de Doutorado apresentada na Escola de Comunicação da Universidade Federal do Rio de Janeiro, 1996.

Almeida, Jorge. Marketing político: hegemonia e contra-hegemonia. São Paulo: Editora Fundação Perseu Abramo; Xamã, 2002.

Aras, Augusto. Fidelidade partidária: a perda do mandato parlamentar. Rio de Janeiro: Lumen Juris, 2006.

Barros, Maurício Ribeiro de. Efeitos de campanha: um estudo sobre a valorização do Horário Gratuito de Propaganda Eleitoral no pleito para a prefeitura de São Paulo em 1996. Dissertação de Mestrado apresentada ao Departamento de Ciência Política da Faculdade de Filosofia, Letras e Ciências Humanas da Universidade de São Paulo, 2001.

Bispo Sobrinho, José, Comentários à lei orgânica dos partidos políticos. Brasília: Brasília Jurídica, 1996.

Bohn, Simone Rodrigues da Silva / David Fleischer / Francisco Whitacker. "A fiscalização das eleições", in Bruno Wilhelm Speck (org.), Caminhos da transparência: análise de dois componentes de um sistema nacional de integridade, Campinas: Editora da Unicamp, 2002, p. 334-354.

Borja, Rodrigo. "Partido político", in Rodrigo Borja, Enciclopedia de la política, 2. ed. rev. e aum., México: Fondo de Cultura Económica, 1998, p. 763-769.

Born, Rogério Carlos. "O direito à compensação fiscal pela propaganda política gratuita", in Informativo eleitoral, v. 16, p. 43-47. 
Braga, Maria do Socorro. "Dinâmica de coordenação eleitoral em regime presidencialista e federativo: determinantes e conseqüências das coligações partidárias no Brasil”, in Gláucio Ary Dillon Soares e Lucio R. Rennó (orgs.), Reforma política: lições da história recente, Rio de Janeiro: Editora FGV, 2006, p. 228-245.

Brasil. Tribunal Superior Eleitoral. Reforma eleitoral: delitos eleitorais, prestação de contas (partidos e candidatos), propostas do TSE. - Brasília: SDI, 2005. Disponível em: <http://tse.gov.br/servicos_online/catalogo_publicacoes/pdf/5 _reforma_eleitoral.pdf >. Último acesso em 14 de novembro de 2009.

Caggiano, Monica Herman Salem. "Corrupção e financiamento das campanhas eleitorais", in Fernando Aurelio Zilveti e Silvia Lopes (orgs.), O regime democrático e a questão da corrupção política, São Paulo: Atlas, p. 116-142.

. Direito parlamentar e direito eleitoral. Barueri: Manole, 2004.

Cândido, Joel José, Inelegibilidades no direito brasileiro. 2.ed. rev., atual. e ampl. Bauru: EDIPRO, 2003.

. Direito eleitoral brasileiro. 13. ed., rev., atual. e ampl., Bauru: EDIPRO, 2008,.

Direito penal eleitoral \& processo penal eleitoral. Bauru: EDIPRO, 2006.

Carrazza, Roque Antonio. Imposto sobre a renda: perfil constitucional e temas específicos. 2. ed., rev., ampl. e atual., São Paulo: Malheiros, 2006.

Carvalho, Rejane Vasconcelos Accioly. "Como se faz um 'fenômeno eleitoral': o caso Roseana", in: Antonio Albino Canelas Rubim (org.), Eleições presidenciais em 2002 no Brasil: ensaios sobre mídia, cultura e política. São Paulo, Hacker, 2004, p. 142-162.

Casseb, Paulo Adib. "Financiamento público de campanha", in Alberto Rollo (org.), Reforma política: uma visão prática, São Paulo: Iglu, 2007, p. 55-70. 
Cerqueira, Thales Tácito Pontes Luz de Pádua / Camila Medeiros de Albuquerque Pontes Luz de Pádua Cerqueira. Fidelidade partidária e perda de mandato no Brasil: temas complexos. São Paulo: Premier Máxima, 2008.

Coneglian, Olivar. Lei das eleições comentada: Lei 9.504/97 com as alterações das Leis 9.840/99, 10.408/02, 10.740/03 e 11.300/06, 5. ed., rev. e atual, 1. reimp., Curitiba: Juruá, 2009.

Coneglian, Olivar Augusto Roberti. Inelegibilidade: inelegibilidade $e$ proporcionalidade, inelegibilidade e abuso de poder. Curitiba: Juruá, 2008.

Costa, Adriano Soares da. Instituições de direito eleitoral. Belo Horizonte: Del Rey, 6. ed., rev., ampl. e atual., 2006.

. "Comentários à Lei no 11.300/2006", in Jus Navigandi, ano 10, n. 1.107, 13.07.2006. Disponível em: <http://jus2.uol.com.br/doutrina/texto.asp? $\mathrm{id}=8641>$. Último acesso em 17.10.2006.

Cunha, Wagner Bispo da. "O artigo 30-A e as suas implicações. Arrecadação, gastos e prestação de contas de campanha eleitoral - Eleições 2008", in Revista IOB de Direito Administrativo, ano III, n. 34, out./2008, p. 8-24.

Denardi Júnior, Adriano. "Prestação de contas de campanha, quitação eleitoral e inelegibilidade", in Revista de Doutrina e Jurisprudência TRE-MG, n. 18, 2008, p. 9-17.

Dias, Maurício. A mentira das urnas: crônica sobre dinheiro e fraudes nas eleições, Rio de Janeiro: Record, 2004.

Ferreira Rubio, Delia. "Financiamento de partidos e campanhas: fundos públicos versus fundos privados" (tradução de Alexandre Morales), in Novos Estudos Cebrap, n. 73, nov./2005, p. 5-15.

Figueiredo, Argelina / Fernando Limongi. Executivo e legislativo na nova ordem constitucional. 2 ed. Rio de Janeiro: Editora FGV, 2001. 
Figueiredo, Rubens. "O marketing político: entre a ciência e a falta de razão", in: Rubens Figueiredo (org.), Marketing político e persuasão eleitoral, São Paulo: Fundação Konrad Adenauer, 2000, p. 11-41.

Fleischer, David. Os partidos políticos. In: Lúcia Avelar / Antônio Octávio Cintra. Sistema político brasileiro: uma introdução. Rio de Janeiro: Konrad-AdenauerStiftung; São Paulo: Editora Unesp, 2. ed., 2007, p. 303-348.

Genoíno Neto, José. “A crise brasileira e a reforma da política”, in João Paulo dos Reis Velloso (coord.), O Brasil e as reformas políticas, Rio de Janeiro: José Olympio, 1992, p. 131-135.

Gomes, José Jairo. Direito eleitoral, 3. ed., rev. e ampl., Belo Horizonte: Del Rey, 2008.

Gomes, Suzana de Camargo. Crimes eleitorais. 3. ed., rev., atual., e ampl., São Paulo: Revista dos Tribunais, 2008.

Guedes, Barbara / Artur Ribeiro Neto. "Fontes institucionais da corrupção no Brasil", in Keith S. Rosenn / Richard Downes (orgs.), Corrupção e reforma política no Brasil: o impacto do impeachment de Collor, (trad. Roberto Grey), Rio de Janeiro: Editora FGV, 2000, p. 47-80.

Jobim, Nelson. "Bases para uma reforma institucional", in João Paulo dos Reis Velloso (coord.), O Brasil e as reformas políticas, Rio de Janeiro: José Olympio, 1992, p. $5-21$.

Jucovsky, Vera Lúcia Rocha Souza. Representação política da mulher. São Paulo: Juarez de Oliveira, 2000.

Kinzo, Maria D’Alva Gil. Radiografia do quadro partidário brasileiro, Rio de Janeiro: Fundação Konrad Adenauer, 1993.

Kuntz, Ronald A. Manual de campanha eleitoral: marketing político. 10. ed., São Paulo:Global, 2004. 
Lima, Eduardo Martins de. Sistemas multipartidários e eleitorais brasileiros em perspectiva comparada (1945-1964 e 1985-1998). São Paulo: Annablume; Belo Horizonte:FUMEC, 2004.

Lima, Sídia Maria Porto. Prestação de contas e financiamento de campanhas eleitorais. 2. ed., rev. e atual., Curitiba: Juruá, 2009.

Lima, Venício A. de. Mídia: teoria e política. São Paulo: Editora Fundação Perseu Abramo, 2001.

Lins, Newton. “Quando o caixa dois e o número um”. in Revista Jurídica Consulex, ano X, n. 216, jan. 2006, p. 30-33.

Machado, Aline. "A lógica das coligações no Brasil", in Silvana Krause / Rogério Schmitt, Partidos e coligações eleitorais no Brasil, Rio de Janeiro: Fundação Konrad Adenauer; São Paulo, Editora Unesp, 2005, p. 43-83.

Machado, Marcelo Passamani. "O financiamento das campanhas eleitorais: perspectivas para uma reforma política", in Monica Herman Salem Caggiano (org.), O voto nas Américas, Barueri: Manole, 2008, p. 183-217.

Mainwaring, Scott P. Sistemas partidários em novas democracias: o caso do Brasil. (tradução de Vera Pereira). Porto Alegre: Mercado Aberto; Rio de Janeiro: Editora FGV, 2001.

. "Brazil: weak parties, feckless democracy", in Scott Mainwaring / Timothy R. Scully (ed.), Building democratic institutions: party systems in Latin America. Stanford, Stanford University Press, 1995, p. 354-398.

Melo, Carlos Ranulfo. "Migração partidária na Câmara dos Deputados: causas, conseqüências e possíveis soluções", in Maria Victoria Benevides / Paulo Vannuchi / Fábio Kerche (orgs.), Reforma política e cidadania. São Paulo: Editora Fundação Perseu Abramo, 2003, p. 321-343.

Mendonça, Duda. Casos e coisas. 1. ed., 7. reimp., São Paulo: Globo, 2001. 
Mezzaroba, Orides. Partidos políticos: princípios e garantias constitucionais, Lei 9.096/95 - anotações jurisprudenciais. Curitiba: Juruá, 2008.

Michels, Vera Maria Nunes. Direito eleitoral: de acordo com a Constituição Federal, LC 64/90, Lei 9.096/95 e Lei 9.504/97. 3. ed. rev. atual., Porto Alegre: Livraria do Advogado, 2004.

Motta, Rodrigo Patto Sá Motta. Introdução à história dos partidos políticos brasileiros. Belo Horizonte: Editora UFMG, 1999.

Musumeci, Toti S. Il costo della politica ed il finanziamento ai partiti, Padova: CEDAM, 1999

Nicolau, Jairo. Multipartidarismo e democracia: um estudo sobre o sistema partidário brasileiro (1985-1994), Rio de Janeiro, Editora FGV, 1996.

. "Para reformar o financiamento de campanhas no Brasil", in Democracia Viva, n. 37, dez./2007, p. 8-12.

. "Notas sobre as eleições de 2002 e o sistema partidário brasileiro", in Cadernos Adenauer, ano IV, n. 1, 2003, p. 14.

. Sistemas eleitorais: uma introdução. Rio de Janeiro: Editora FGV, 4. ed., 2002.

Nunes, Augusto. A esperança estilhaçada: crônicas da crise que abalou o PT e o governo Lula. São Paulo: Planeta, 2005.

Panebianco, Angelo. Modelos de partido: organização e poder nos partidos políticos. (tradução de Denise Agostinetti). São Paulo: Martins Fontes, 2005.

Porto, Roberto. Lei eleitoral anotada: Lei n. 9.504, de 30 de setembro de 1997, São Paulo: Saraiva, 2009.

Porto, Walter Costa. "O TSE e a reforma eleitoral-partidária", in Brasil. Tribunal Superior Eleitoral. Reforma eleitoral: delitos eleitorais, prestação de contas (partidos e candidatos), propostas do TSE. - Brasília: SDI, 2005, p. 9-13. 
O voto no Brasil: da Colônia à $\sigma^{a}$ República, 2.ed. rev., Rio de Janeiro: Topbooks, 2002.

Reis, Daniel Gustavo Falcão Pimentel dos. Verticalização das coligações partidárias: melhor caminho para a coerência político-eleitoral?, Disponível em: $<$ http://www.sbdp.org.br/artigos_ver.php?idConteudo=42>. Último acesso em 15.11.2009.

, “Os partidos políticos $\mathrm{e}$ as organizações não governamentais: proposta de trabalho conjunto", in Instituto Tancredo Neves Partido da Frente Liberal, Prêmio Luís Eduardo Magalhães - $8^{a}$ edição ano 2005, Brasília: ITN, 2006, p. 15-36.

Reis, Fábio Wanderley. "Dilemas da democracia no Brasil”, in Lúcia Avelar e Antônio Octávio Cintra, Sistema político brasileiro: uma introdução, 2. ed. rev., e ampl., Rio de Janeiro: Konrad-Adenauer Stiftung; São Paulo: Editora Unesp, 2007, p. 467-487.

Ribeiro, Renato Janine. "Financiamento de campanha (público versus privado)", in Leonardo Avritzer e Fátima Anastasia (orgs.), Reforma política no Brasil, Belo Horizonte: Editora UFMG, 2006, p. 77-81.

Ribeiro, Renato Ventura. Lei eleitoral comentada. São Paulo: Quartier Latin, 2006.

Rodrigues, Fernando. Políticos do Brasil, São Paulo: Publifolha, 2006.

Rodrigues, Leôncio Martins. Partidos, ideologia e composição social: um estudo das bancadas partidárias na Câmara dos Deputados. São Paulo: Editora da Universidade de São Paulo, 2002.

Rollo, Alexandre Luis Mendonça, "Propaganda eleitoral no rádio e na televisão", in Alberto Rollo (org.), Propaganda eleitoral: teoria e prática. São Paulo: Revista dos Tribunais, 2002, p. 84-125.

Rubim, Antonio Albino Canelas. "Visibilidades e estratégias nas eleições proporcionais de 2002: política, mídia e cultura", in Antonio Albino Canelas Rubim (org.), 
Eleições presidenciais em 2002 no Brasil: ensaios sobre mídia, cultura e política. São Paulo, Hacker, 2004, p. 7-28.

Samuels, David. "Financiamento de campanha e eleições no Brasil: o que podemos aprender com o 'caixa um' e propostas de reforma”. In: Maria Victoria Benevides; Paulo Vanucchi; Fábio Kerche (orgs.); Reforma política e cidadania. São Paulo: Editora Fundação Perseu Abramo, 2003, p. 364-391.

Santa Rita, Chico. Batalhas eleitorais: 25 anos de marketing político. São Paulo: Geração Editorial, 2001.

Santoro, Ana Cláudia. "Os procedimentos para o financiamento de campanhas eleitorais e a problemática da prestação de contas dos recursos utilizados", in Paraná Eleitoral, n. 52, mai.jun. 2004, p. 69-79.

Santos, Eurico A. Gonzalez Cursino dos. "Comentários ao PL 2.679/2003, da Comissão de Reforma Política da Câmara dos Deputados”. Revista de Informação Legislativa, ano 41, n. 161, jan./mar. 2004, p.9-20.

Santos, Fabiano. "Reformas políticas na presidência de Fernando Henrique Cardoso", in Cadernos Adenauer, ano III, n. 3, 2002, p. 25-39.

Santos, Fernando Muniz. "Abuso de poder econômico eleitoral: por uma definição complessiva desse instituto", in Antenor Demeterco Neto (coord.), Os abusos nas eleições: a conquista ilícita de mandato eletivo, São Paulo: Quartier Latin, 2008, p. 34-58.

Schlickmann, Denise Goulart / Heloísa Helena Bastos Silva Lübke. "Financiamento de campanhas eleitorais: avaliação das propostas apresentadas pelo Tribunal Superior Eleitoral ao Congresso Nacional”, Resenha eleitoral: nova série, v. 15, 2008, p. 129-150.

Financiamento de campanhas eleitorais. 4. ed., rev. e atual., Curitiba: Juruá, 2008. 
Schmitt, Rogério / Karina Kuschnir / Leandro Piquet Carneiro. "Estratégias de campanha no horário gratuito de propaganda eleitoral em eleições proporcionais", Dados, v. 42, n. 2, 1999.

Coligações eleitorais e sistema partidário no Brasil. Tese de Doutorado apresentada ao Instituto Universitário de Pesquisas do Rio de Janeiro, 1999.

Serra Rojas, Andrés. "Partido político", in Andrés Serra Rojas, Diccionario de ciencia política, 2. ed., 1. reimp., 2001, p. 831-832.

Silva, Fernando Neves da. "Financiamento da campanha política e corrupção eleitoral", in Revista Jurídica Consulex, ano VII, n. 144, p. 36-40.

Singer, André. Esquerda e direito no eleitorado brasileiro: a identificação ideológica nas disputas presidenciais de 1989 e 1994. 1.ed., 1. reimp., São Paulo: Editora da Universidade de São Paulo, 2002.

Speck, Bruno Wilhelm. "Cinco teses sobre o financiamento da competição política e a proposta da respectiva reforma", in Revista Jurídica Consulex, ano VIII, n. 179, jun.2004, p. 35-37.

Tavares, José Antônio Giusti. Sistemas eleitorais nas democracias contemporâneas: teoria, instituições, estratégia. Rio de Janeiro: Relume-Dumará, 1994.

Velloso, Carlos Mário da Silva / Walber de Moura Agra. Elementos de direito eleitoral. São Paulo: Saraiva, 2009.

Viera, Tarcisio. "Experiencias nacionales representativas: Brasil". In: Daniel Zovatto et.all (coord.). Dinero y contienda político-electoral: reto de la democracia. México: Fondo de Cultura Económica, 2003, p. 425-434.

Villar, João Heliofar de Jesus. "Corrupção: o ovo da serpente", in Folha de S. Paulo, edição de 4.1.2010, p. A3. 
Woldenberg, José. "Relevancia y actualidad de la contienda político-electoral", in Daniel Zovatto (coord.) et.all. Dinero y contienda político-electoral: reto de la democracia. México: Fondo de Cultura Económica, 2003, p. 17-29.

Zovatto, Daniel. "Financiamento dos partidos e campanhas eleitorais na América Latina: uma análise comparada" (tradução de Pedro Maia Soares), in Opinião Pública, v. XI, n. 2, out./2005, p. 287-336. 